\title{
TWEEDE GEDEELTE.
}

\author{
De opstand in de Molukken onder het \\ bestuur der commissie Engelhard- \\ Van Middelkoop.
}




\section{HOOFDSTUK I.}

\section{Orer de oorzaken van den opstand.}

Het milder Engelsche tusschenbestuur. - De druk onzer O. I. C. De gunstiger meening der Inlanders over het Britsche bestuur. - De waarschuwingen over verzet tegen het Nederlandsche bestuur. - Het geldgebrek der Moluksche commissie. - Engelhard's meening over de oorzaken van den opstand. - Buijskes' rapport betrekkelijk die oorzaken.

- Het rapport-Porto.

Nederlandsche geschiedschrijvers hebben er met eenigen nadruk op gewezen, dat het Moluksche specerij-monopolie onder het Engelsche tusschenbestuur gehandhaafd bleef; een nadruk volkomen op zijn plaats tegenover het geschetter van Raffles en de zijnen, alsof dezen de baanbrekers zijn geweest van een vrijheid, die de Nederlandsche Oost-Indische Compagnie en hare kortstondige opvolgende besturen nooit hadden toegelaten '. Met dit te memoreeren, ter afbreking van opgeschroefdeu lof, wordt echter niet alles gezegd; want blijvende op het gebied, dat deze verhandeling omvat, erkend moet worden, dat er een oneindig milder en, in de personen van de gezagsvertegenwoordigers, verstandiger bestuur optrad dan voorheen er was geweest. Een niet ten lof geschreven uiting van den Kroniekschrijver over hetgeen de commissarissen Engelhard-Van Middelkoop te Ambon aantroffen, getuigt er met zoovele woorden van: "Zij vonden", verhaalt Mr. Mijer ${ }^{2}$, "den allcenhandel in specerijen overal ondermijnd en als het ware met ondergang bedreigd, daar, tijdens het Britsche tusschenbestuur, de particuliere handel aldaar zoo zcer was toegenomen, dat Amboina kon gezegd worden, de stapelplaats geworden te zijn van den geheelen Indischen handel ten Oosten van Java. Schepen uit het Westen van Indië bragten aldaar lijnwaden, opium en Europesche goederen, die, na de opening van de vrije vaart van Engeland op Indië aldaar zeer goedkoop te bekomen waren." Dat zijn de woorden niet van een Van Doren, die van het Engelsche bestuur meent te moeten getuigen: "meer het verval dan den bloei dezer eilanden schijnt te hebben beoogd" 3 , maar van een buitengewoon knap man.

1 Verg. dl. I, bl. 383, 384, 391, 450.

${ }^{2}$ Kronïk, bl. 346-347.

3 Van Doren-F., dl. I, bl. 331. 
Hoeveel rampen bracht niet het Compagniesbestuur in dit paradijsland met de stelselmatige vernieling der specerij-boomen, te grooter, omdat menigmaal wat te voren was uitgeroeid, opnieuw moest worden aangeplant, veroorzakende "het aanplanten van zulk groot getal uagulboompjes geen kleen misnoegen onder de julanders van Amboina, die niet konden begrijpen waarom nu met zulke rigoruisheid de nagulen aamplanten, die men kort te vooren zoo ijverig uijtgeroeijt hadde" 1. Daardoor verkeerde al zeer spoedig het gezag, waarnaar de Hitoeneezen ter vervanging van dat der Portugeezen als gesnakt hadden ${ }^{2}$, in verachtiug zóó, "dat alle osstersche volkeren d'onze verweten dat wij in plaets van met manuen met boomen oorloogden". Niet zonder intelligente scherpte merkten zij tegen 'n Arnold de Vlaming op, als deze vlootvoogd de vernieling eischte - daar "de Comp. geene Nagels meer zoude behoeven aan te nemen als de geheele wereld soo wijd en breet die van God de Heer geschapen was konde vertieren" - "dat men haarlieden dan behoorde toe te staan met den overschot te doeu en handelen naar haar believen, want verzekerden ons dat zij die wel wisten aan de man te brengen schoon dat wij de weereld te voren met 1500. Bharen al geprovideerd hadden" 3 .

En het was niet alleen de politiek van vernieling op zichzelf, die drukte, maar ook de daarmede samengande middellijke gevolgen, wasandor dat hot ganeahe huichaudolijle lovon dor vaor do hangitochten gepresten verstoord werd, zoodat met den grooten opstand in 1637 de vraag luidt ${ }^{4}$ : "Dat niemant van de burgers off andere Liedeu slaeven, geduurende haere absentie met de Hongij in hare thuijnen mogten vallen, gabbe gabben ${ }^{5}$ en atap nevens andere vrugten uijthaelen, zoo datse 't Huijs komende dikwils niet vonden, waer door als dan met wijf en kinderen mosten honger leijden". Dan ook werd aan de arme kerels de vastgestelde betaling voor de verplichte levering van het product onthouden, wordende niet "hare Nagelen opregt gewogen" 6 . Wel nam het bestuur te Batavia daartegen maat-

1 Rumphius, dl. II, bl. 107 over het jaar 1656. - Ten aanzien van de koffiecultuur in de Preanger geheel hetzelfde: men leze het zeer belangrijke hoofdstuk VII in Priangan, dl. I, bl. 116* v.v.

2 Zie dl. I, bl. 422. - De in den tekst volgendo aanhaling bij Rumphius, dl. I, bl. 232 over het jaar 1644.

s Rumphius, dl I, bl. 289.290 over het iaar 1650.

4 Rumphius, dl. I, bl. 147.

5 Gaba gaba: de hoofdnerven van den sagopalm, voor wanden van huizen.

6 Verg. de mededeeling in Priangan, dl. I, bl. $174^{*}$. 
regelen ${ }^{1}$, doch met welk slag van plaatselijke ambtenaren gouverneur Arnold de Vlaming had te doen, lezen wij als volgt onder $164.7{ }^{2}:$ : $\mathrm{Op}$ Hitoe vielen klagten over den Resident dat hij groot bedrog had bedreveu bij 't inweegen der Nagelen en de inlanders merkelik verongelijkt hadde, dies denzelven van zijn comptoir geligt en aan 't Casteel gebragt wierde; de schraapsugt van zommige Comps Dienaren nam zodanig toe en dat zoo openbaar en stout dat het scheen als ofze een wed spel ingestelt hadden, dus het ook hoog nodig was dat den nieuwen Gouverneur met harde straffe tegens deze verdervelijke menschen voorzage dewelke anders een zoo duur verworvene vrede in 't korte weder omver gestooten zouden hebben, dog dit baarde den Gouverneur zoo veel nijts en onlusten dat hij in zulke stribbelingen (die hem zijn eigen officiers aandeeden) bijkans zijne geheele regeeringe toegebragt heeft" " 3 . Wanneer wij aan het einde vau dit hoofdstuk Buijskes' rapport over de vermoedelijke oorzaken van den opstand van 1817 lezen, zullen wij daarin de getuigenis terugvinden, dat deze verderfelijke geest destijds niet geheel uit onze landsdienaren was geweken.

Daarentegen waren als regel de onder het Engelsche bestuur aangestelden geen onontwikkelde philisters, die, bijgestaan door sirihpruimende nonna's, slechts in sinjo-taal hun gedachten wisten uit te drukken, en dus ook overigens geen andere ontwikkeling hadden dan de dagelijksche bezigheden hun aanbrachten. De Inlander der Molukken kende tot de komst der Engelschen niet anders dan wat hij noemde en warmede alles gezegd was: de Compagnie, en scheen niet anders te weten dan dat, zooals hare dienaren hun plichten begrepen, het ook zoo behoorde. Met het optreden van het Britsche bestuur kreeg hij kijk op een vrijzinnige richting, waarvoor hij te meer moest gevoelen, nu dat bestuur met 1817 weer dreigde heen te gaan Ook al zoude zijn onguustige stemming tegen het terug-

1 „Jn dit voorjaar", leest men bij Rumphius, dl. I, bl. 278-279, over 1649, nwas ordre van Batavia gekomen dat men om alle morsserijen bij 't inweegen der Nagelen te voren gebruijkt vor te komen een nieuw metaale gewicht zoude invoeren gelijk het zelve doenmaals ran Batavia gezonden was, waar op het getal der ponden soo wel met moorsche als duijtsche letteren ingegraveert was op dat het een ijder duijdelijk bekennen en optellen konde; dan dat bij 't inweegen der Nagelen een gesworen inlandsche schrijver in 't weegen bij moeste zijn die zig op het gewicht verstond en dat zonder deszelfs prezentie niet een pont mogt ingewoogen worden."

2 Rumphius, dl. I, bl. 268.

${ }^{8}$ Zie ook Rumphius, dl. I, bl. 284-285, over de ontrouw der ambtenaren. 
gekomen gezag niet geprikkeld zijn, gelijk de Kroniekschrijver in overeenstemming met Buijskes mededeelt ${ }^{1}$, "door onzinnige denkbeelden van vrijheid en onafhankelijkheid, tijdens het Britsch Bestuur als het ware moedwillig opgewekt", lag het toch wel in den aard der zaak, dat wij in veel ongunstiger omstandigheden terugkwamen, dau waariu wij er vroeger geweest waren. Ook Engelhärd in zijn brief van 16 Juni 1817 aan Elout merkt niet ten onrechte op: "De verschillende zeden en gewoonteus der Eugelschen van de onzen hebben zeer zeker geen goed in de Molukkos verspreid, en de volkeren alomme geheel andere principes ingeboezemd." Men leze ook vooral an het slot van dit hoofdstuk, wat Buijskes over de bedenkelijke wijziging in den publieken geest mededeelt.

De Inlander - het werd reeds aangeteekend - verborg zijn weerzin onder die verandering niet ${ }^{2}$, zóó weinig, dat acht dagen na de komst der Moluksche commissie, de pakhuismeester De Keyzer ten huize van predikaut Kam zou gezegd hebben het volk nict te veel te vertrouwen, want het zou ligt mogelijk zijn, dat er onaangename voorvallen na het vertrek der Engelschen plaats hadden; opvallend was het o. a., merkte hij op, dat nu reeds al de schoolmeesters van Saparoea de hoofden bij elkander hadden gestoken on voor Matulesi, den leider van den weldra uit te breken opstand, een in het oog loopende vrees hadden. Het is niet te bepalen, in hoever dergelijke verhalen, die een niet zeer critisch angelegd schrijver van latere jaren noteerde ${ }^{3}$, werkelijk op waarheid berusten, maar een feit is het in ieder geval, dat het aan aanwijzingen over verstoordheid niet heeft ontbroken. Het had tot voorzichtigheid moeten leiden, een voorzichtigheid in zoover ook bij de instructie der Moluksche commissie betracht, dat zij de lastgeving bevatte om vooralsuog de Britsche bestuursrichting te blijven volgen.

Stomme Van Middelkoop stoorde zich daaraan niet en nam allerlei maatregelen, die tot ongenoegen konden leiden; leuterende Engelharl bleek de man niet om deu storm nog tijdig te bezweren ${ }^{4}$. Onder zulk een leiding, of geen leiding, konden de gewestelijke ambtenaren, naar het karakter toevallig medebracht, mede hun gang gaan en aan hun aanmatiging den teugel vieren. Dat het geschiedde en met zulke schrikkelijke gevolgen, deed overste Ver Huell, die als

1 Kronïk, bl. 347.

2 Dl. I, bl. $452-454,476,513$.

s Van Doren-M., bl. 7.

4 Verg. dl. I, bl. 538-539. 
commandant van een der te Ambon geplaatste oorlogsschepen den Molukschen opstand medemaakte, de waardige woorden schrijven ${ }^{1}$ : "Ook is het eene vreesselijke les voor menig Europeaan, die eenig gezag over deze zoogenaamde zwarten of wilden verkregen heeft, en zich het ellendig denkbeeld heeft eigen gemaakt, om hen juist daarom als slaven ongestraft te kunnen onderdrukken. Hebben zij ook niet eene geregte aansprank, als bedeeld met het Goddelijk licht der rede, om als menschen behandeld te worden, - met regtvaardigheid en eene liefderijke toegenegenheid, geëvenredigd naar hunne inborst en zeden? Zoo handelde de groote Cook, de edele en ongelukkige $\mathrm{La}$ Perouse en meer andere menschkundige reizigers. Geen volk, hoe woest, of onbeschaafd het ook moge zijn, of het laat zich veeleer door eene liefderijke behandeling leiden, dan door eenen wreedaardigen dwang."

Een opstand, als in de Molukken uitbrak, is op breede schaal in de dorpen voorbereid; onmogelijk, dat de volkshoofden er geheel onkundig van blijven. Voor de hoofden, die om welke redenen dan ook, er geen heil in zien, wordt de positie soms zeer moeilijk en moet de al of niet openbaring aan het Europeesche gezag inwendigen strijd kosten. Iedere mededeeling op dit gebied is een daad, ook dan wanneer het mocht blijken, dat de berichtgever zich vergist of overdreven voorstellingen van het naderend gevaar gemaakt heeft. De Europeesche bestuurshoofden kunnen niet tegemoetkomend genoeg jegens zulke menschen optreden, willen zij niet de berichtgeving ontmoedigen en zich aldus aan de mogelijkheid blootstellen, dat zij plotseling, onvoorbereid tegenover het gevaar staan. Van die welwillendheid is hier echter niets te bespeuren. Met een roekeloosheid, die mij Van Doren's mededeelingen er over onmogelijk deed schijnen, alzoo oorspronkelijk niet ten volle deed aannemen, worden de berichtgevers afgeranseld, in arrest gesteld, weggesnauwd; en niet door één bestuurshoofd, die het op zijn heupen heeft, doch door allen, tot wien de berichtgevers zich wenden. Buijskes zelf deelt inderdaad mede, dat onze bestuurshoofdeu waarschuwingen ontvingen, doch dat men deze, om met Rumphius te schrijven over waarschuwingen, die aan den opstand van 1651 voorafgingen, in geen groot agtinge vernam" 2 .

Toen Van den Berg te Saparoea het bestuur anvaardde, scheen er een idyllische rust te heerschen. "Ik kan UEdGestr. nochtans

1 Ver Huell, dl. I, bl. 128.

2 Rumphius, dl. II , bl. 9. 
verzekeren", schreef op het bericht der rebellie Ternate's resident Neys, die er tevoren bestuurshoofd was geweest ' , ann Engelhard, "dat ik gedurende mijn ruim zeven-maandig bestier, onder het Engelsch Gouvernement gelijkelijk over de beide residentien Saparoea en Haroeko, zulk een volkomen vertrouwen in die Eijlanders gesteld hebbe gehad, dat ik nimmer van dergelijke opstand zoude gedroomt hebben." Had Van den Berg er maar van gedroomd, althans toen hem er aanleiding voor werd gegeven. Preter Matheus Sовнока kwam hem vertellen, dat er ontevredenheid broeide. De Resident hoorde er over de regenten van Boi en Nolot $^{2}$ : zij wekten bij hem de overtuiging, dat het slechts kwaadwillige prantjes waren. Tot straf dier kwaadwilligheid liet Van den Berg an Soehoka binnen 's huis rotauslagen geven! Een paar dagen later kwam de vrouw van radja Nolot — de njora, zooals de vrouwen van negorijhoofden genoemd worden ${ }^{3}$ - een kopje kolfie bij mevrouw de Residentsche drinken, en vertelde toen in haar ounoozelheid, dat Soehoka toch werkelijk de waarheid had gesproken en alzoo onrechtvaardig was gestraft, dat er dagelijks te Nolot vergaderingen plaats vondeu en de negorijbewoners hun wapenen in gereedheid brachten ${ }^{4}$. Deze Soehoka heeft zich van den aanvang af, naar wij nog lezen zullen, bij den opstand aangesloten; ook heet het, dat hij, toen al de kinderen van de familie Van den Berg neergeveld waren, medegewerkt heeft om één ervan in veiligheid te breugen. Begrepen wordt anders door mij niet, dat de opstandelingen toegelaten hebben een der hunnen, die hen eerst had willen verraden, een rol in de rebellie te doen vervullen; een geheim zal dat verraad wel niet gebleven zijn.

In verband hiermede is opmerkelijk hetgeen geschiedde met het Christen-negorijhoofd van Siri Sori ${ }^{5}$, "een getrouw en aan het Nederlandsch gouvernement verkleefd Regent" "6, Johannes SaLOMon Kirauly. Zijn dorpsgenooten mochten hem niet; zij beweerden, dat hij ze niet goed behandelde. Kirauly dan had mede van opstandsplannen vernomen. Hij durfde er niet bij den Resident mede aankomen, "omdat hij bevreesd was, dat de Resident hem als den zegsman zoude bekend maken, en dat hij dan gewis met zijue geheele familie

1 Verg. dl. I, bl. 391.

2 Over deze plaatsen, dl. I, bl. 470 en 471.

s Van Hoëvell, bl. 20.

4 Het Soehoka-verhaal bij Van Doren-M., bl. 16-17.

5 Verg. dl. I, bl. 474.

6 Van Doren-M., bl. 17, waar ook de bijzonderheden, die in den tekst volgen. 
door de eilanders zoude omgebragt worden"; doch er ook niet over willende zwijgen, voer hij naar Ambon, waar hij zijn hart luchtte an onze Commissarisseu. Ook hij kwam echter vau eeu slechte markt thuis of liever hij kwam niet thuis, "aangezien de Landvoogd van Middelkoop, noch de heer Engelhard, mede Kommissaris voor de overname der Molukko's, aan zijne confidentiële kennisgeving geloof wilden slaan en hem te Amboina in stads arrest hielden". ls dit alles inderdaad juist? Het. feit staat vast, dat bij het uitbreken vau den opstand Kirauly zich te Ambon bevond; het kàn mogelijk zijn, dat hij er voor het aangegeven doel naar toc is gegaan en dat Engelhard, van deze reis naar Ambon melding makende, de waarschuwing onbesproken laat, om zichzelf niet bloot te geven; maar dat hij in een brief aan Siberg het ougelukkige einde van zoo velen, die met de expeditie-Beetjes naar Saparoea gingen, ó́k Kirauly memoreert in deze woorden "alsmeede de Radja van Sorry Sorry, een waardig en respectabel man, die zich hier bevond en te zelver tijd naar zijn rijkje is terug gekeerd, doch door de muitelingen is afgemaakt"; dat hij dit doet zonder tevens te melden, dat Kirauly stads-arrest - door den Gouverneur? - was opgelegd, is natuurlijk wel denkbaar, doch zonderling.

Het zou ook niet bij waarschuwingen uitsluitend van Saparoea zijn gebleven. Zekere Latukomia Oмa was een ouder het Britsche bestuur ontslagen hoofd van de negorij Pelaoe ${ }^{1}$. Deze, zoomede zijn

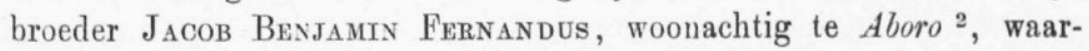
schuwden resident Uijtenbroek vau Haroekoe, hetgeen Engelhard in zijn Bataviansch verslag aldus mededeelt: "Op den $20^{\circ}$ April en dus slegts 21 dagen na dat den Heer van den Berg het gezag op Sapparoua had aanvaard 3, hadden de gewezeue Radjas van Polouw en Aboro, beide aan het Nederlaudsche Gouvernement ten nauwsten gehecht, den Resident van Haroekoe verwittigd, dat er een bijeenkomst in de bosschen vau het district Liang belegd was, sterk over de 100 koppen, alwaar men ene conspiratie tegens het Nederlandsche Gouvernement stond te smeden, bij welke gelegenheid zich dat vloekgespan op de plegtigste wijze met een stond te verbinden om

1 Verg. dl. I, bl, 467.

2 Verg. dl. I, bl. 466.

s Engelhard brengt dit in herinnering, daar bij niet gelooft aan de schuld van Van den Berg - verg. bl. 547 en 569 noot 1 - en „als zeker" stelt, "dat indien de Engelschen nog enige tijt in het bezit der Molukkos waren gebleven, dit oproer ook onder hunne Regering zoude zijn uitgebarsten". Echt Engelhardsche wijsheid! 
door het afzenden van opene brieven ann de volkeren van Ceram en elders hun te inclineren om zich van het Nederlandsche Gouvernement af te scheuren, en tot die samenswering uit te nodigen; de zwakke staat der bezetting kennende, zoude dit hun boos voornemen aanmerkelijk hebben gefaciliteerd." Naar aanleiding dezer waarschu wing, werd den radja van Samet ${ }^{1}$ een onderzoek opgedragen. De geschiedenis van Saparoea herhaalt zich hier. De Radja toch gaf den Resident ua eenigen tijd de verzekering, lezen wij ${ }^{2}$, "dat het gerucht valsch was en dat het slechts verdichtselen vau bovengenoemde personen waren, hetgeen den Resident Uijtenbroek deed besluiten genoemde personen voor zich te doen komen en hen naar Amboina op te zenden, waar zij, eveu a!s de Radja van Sory-Sory Seranie onder strikte surveillantie der politie bleven."

De Moluksche commissie had van Batavia zeer weinig fondsen medegekregen, ' zóó weinig, dat Engelhard zich verplicht zag geld te Ambon op te nemen en daarvoor een wissel af te geven. Het laat zich niet zeggen, of en tot welke mate die bekrompenheid van middelen tot de uitbarsting van het verzet middellijk heeft medegewerkt; maar wel kan men zich den invloed hiervan voorstellen. Herinueren wij ons de malle geschiedenis bij het vertrek naar Menado van resident Martheze, dien Van Middelkoop zonder geld, naar het schijnt, wilde doen vertrekken ${ }^{3}$. Het geldgebrek moest ook de Moluksche commissie prikkelen om spoed te maken met papieruitgifte en niet al te ruim wisselkantoren te openen. Immers slechts te Ambon, Banda, Ternate: wat baatte dit o. a. de Oeliasers? Bovendien het papier van $f 1$ was niet eeus wisselbaar, juist derhalve de meest beunodigde kleine munt ${ }^{4}$. Teekenend schijnt, wat men zouder meer leest in het journaal van Boelen ad 7 Februari 1818, let wel in den aanvang van Februari, bij uitbetaling van soldijen op de Reygersbergen: "Het $\frac{1}{4}$ verdiende soldy over de maanden Julij, Aug. en September 1817 betaald met papiere ropijen -26 hollandsche stuivers het stuk gerekend." Hoe hield men er nog een goede stemming in? Zulk een verregaand geldgebrek spoorde de plaatselijke bestuurshoofden allicht mede aan om door heerendienst en verplichte levering te

1 Verg. dl. I, bl. 465.

2 Van Doren-M., bl. 18. De Schrijver spreekt steeds van den radja van Siri Sori Seranie, ofschoon er destijds slechts één negorij Siri Sori bestond; zie hiervóór, dl. I, bl. 474.

s Zie dl. I, bl. 535. - Over het gemis aan fondsen, verg. mede dl. I, bl. 402.

4 Verg. bl. 519. 
doen verkrijgen, wat men liever niet wilde betalen, terwijl ook door de schrikbarende verwaarloozing van gebouwen, versterkingen, wegen, veel, heel veel te doen viel. Pas optredende bestuurshoofden kennen bovendien soms geen grenzen aan hun ijver tot veranderen; in een vloek en een zucht moet het maar worden gedaan. De nauw uit Holland gekomen en den 21 ${ }^{n}$ Maart 1817 als resident van Saparoea opgetreden jeugdige Van den Berg schijut niet begrepen te hebben, wat de eisch der omstandigheden medebracht. Als het hoofd van den opstand Matulesi eeu publicatie, gedagteekend Saparoea, 12 Juli 1817 aan de inlandsche hoofden der negorijen van de eilanden doet afgaan om allen op te wekken aan den opstand deel te nemen, schrijft hij, dat men zich verbonden heeft: "om de bevielen van den Resident niet meer op te volgen, omdat de Residenten hen op allerlei manieren onderdrukt en gedwongen hebben, zonder dat zij eenige belooning kregen voor hun werk" ${ }^{1}$. Indien de bewoordingen juist zijn weergegeven - het is eenigszins vreemd, dat zulk een rondschrijven eerst een maand na het uitbreken van den opstand afgaat - dan ligt daarin opgesloten, dat met het herstel van het Nederlandsche gezag de lasten drukkender waren geworden.

De opstand had naar een te wel beraamd plan plaats, dan dat hij zich voorloopig zou beperken tot Saparoea; zoo goed als te gelijker tijd, d. w. z. nadat de uitbarsting aldaar ruchtbaarheid had gekregen, kwamén ook de andere Oeliasers, Ceram's zuidkust, ja het eiland Ambon zelf, in verzet. Gelijk in 1636 was het alsof "het geheele gebouw van den Ambonschen stant begon op een zij te hellen", toen het vuur vau den opstand "vloot met er haast voort van Leytimor tot in de naburige Oeliaschersche eijlanden" en men vond "voor eerst geen betereu raad als het hooft binnen de schansse te houden en belasten een ijder sijn nest te bewaren" 2 .

1 Het rondschrijven vindt men bij Ier Huell, dl. I, bl. 131-132. De Schrijver bericht, dat hij "toevallig" eigenaar werd van het stuk, ,eigenhandig door het opperhoofd Thomas Matulesia, geteekend" en dat hij het "letterlijk" deed vertalen. Jammer, dat hij er geen fac simile van bijvoegde. - Engelhard aanvaardde blijkens zijn Bataviaasch verslag de beschuldigingen tegen Van den Berg, ook wat aanging het afstraffen en in de ijzers klinken van Anthonie Rhébok niet, schrijvende ndeze worden direet gerefuteerd door de confessien der gevangen muitelingen Thomas Matulesie, Oeloepaha, Philip Latumahina, Capitein Lucas van Nolloth en Anthony Rebok, die als eerste aanroerders met den dood zijn gestraft en opentlijk op het schavot hunne depositiën hebben bekrachtigd". - Hierna zullen wij in het rapport-Porto ook lezen, dat Van den Berg geen schuld zou gehad hebben.

${ }^{2}$ Rumphius, dl. I, bl. 124-127. 
Nooit is positief uit te maken, waar de meer rechtstreeksche oorzaken van volksonlusten zijn gelegen en het standpunt der verantwoordelijke bestuurders brengt vanzelf mede te betoogen, dat de beweging geheel buiten hun schuld ontstond. Engelhard's beschouwingen er over in zijn Bataviaasch verslag zijn uit dien hoofde van weinig waarde. Hij, die in een particulier schrijven Van Middelkoop als den hoofdschuldige had aangewezen ', verklaarde nu, dat de oorzaken van den opstand hem "ten eenemaal onbekend" waren, en het hem ook niet mogelijk was geweest daarin licht te ontsteken, "alzo de communicatie met Sapparoea had opgehouden, en de correspondentie met Amboina finaal was gestaakt". Dit weerhoudt hem intusschen niet in uitgebreide beschouwingen over de annleiding van het verzet te treden; hij zoekt haar o. a. "in de afkeer die de Moluksche volkeren over het algemeeu voeden voor alle ondergeschiktheid of maatschappelijke verdragen, als van aart tot ene onafhankelijke eigendunkelijke gemakkelijke levenswijze geneigd zijnde, door welke nijgingen zij aangeprikkeld wierden om zich van alle onderwerping aan een regelmatig gezag te outwringen, en die misleidende verwagting, dat zij even en gelijk de volkeren van Ceram en elders geheel op zichzelven zoude staan en tot gene opgelegde verpligtingen verbonden zijn".

Dit is zeker algemeen genoeg. Van belang daarentegen mag geacht worden het bezadigd en wel overwogen rapnort. van. den. schont ? $_{i j}$ nacht Buijskes, dat hij, gedagteekend Kedong Allang 10 October $1818 \mathrm{~N}^{\circ}$. 472 Secreet, dus toen hij na de onderdrukking van de rebellie, te Batavia was teruggekeerd, speciaal over de oorzaken aan C. C. G. G. heeft ingediend. Buijskes was reeds na den vrede van Amiens in de Molukken geweest, om hetzelfde te verrichten, wat aan Engelhard-Van Middelkoop in 1817 werd opgedragen, namelijk de Molukken uit de handen der Engelschen over te nemen. Een vreemdeling kon hij daar alzoo niet genoemd worden, toeu C. C. G. G. hem uitnoodigden opnieuw derwaarts te gaan om zoo noodig de plaats der heeren Engelhard-Van Middelkoop in te nemen en het gezag er te voeren tot herstel der rust. Hij heeft die taak op afdoende wijzen en goed vervuld, hetgeen te meer waarde aan zijn beschouwingen doet geven, gelijk ik ze hier laat volgen:

Ik heb de eer Uwe Excellentien bij dezen mijne gedachten mede te deelen, wegens de oorsprong en verdere aanleidende oorzaken, van den plaats gehad hebbende gevaarlijken opstand, onder de ingezetenen der Moluksche Eilanden.

' Zie dl. I, bl. 539 en 547. 
In de eerste plaats vermeen ik met eenige zekerheid te kunnen vooronderstellen: dat de ingezetenen dier eilanden, vooral van de afgelegene residentien onder het voormalig bestier van de O. I. Compe. door deszelfs bedienden in het algemeen, en wel door de residenten in het bijzonder, zeer gedrukt en gekneveld zijn geworden.

Om hier van verzekerd te zijn behoeft men slechts nategaan: het aanzienlijk vermogen dat onderscheiden residenten van Saparoua (: om van geene anderen melding te maken:) aldaar bij een vergaard hebben.

Ik ben toevallig in de gelegenheid geweest om uit den staat des boedels van een gewezen resident van Saparoua, circa veertig jaren geleden aldaar in functie geweest zijnde, te ontwaren, dat die ambtenaar in een zeer korten tijd, een vermogen van $10 \% / \mathrm{m}$ Rijks-daalders had bij een geschraapt, en daar de bezoldiging van een resident des tijds zeer gering en er bijna geene gelegenheid was, om eenigen smokkelhandel in specerijen te drijven, zoo blijft er niets over, dan mijne vooronderstelling van knevelarij aan te nemen.

Dit wordt nog meer bevestigd door de aanzienlijke schuld die de erven van den gewezen resident van Saparoua Blondeel nog te vorderen hebben van verscheiden der voornaamste Hoofden van dat eiland, en waarvan de obligatien door den gewezen Britschen resident Martin zijn opgeëischt en aan Commissarissen tot de overname overgegeven: also hij vermeende in de schuldvordering te hebben moeten difficulteeren.

Deze schuld was (:als ik het wel heb:) oorspronkelijk van boetens, door den Gouverneur der Molukkos in den tijd aan die Hoofden opgelegd, en die door den resident moesten worden voorgeschoten; daarvoor werd aan dezen overgelaten, om dezelve op de best mogelijke wijze in te vorderen, die alsdan deswegens schikkingen maakte, door obligatiën te doen paseeren, of te wel panden daarvoor te nemen, in zoo verre het aandeel, dat de Hoofden der negorijen uit de betaling der specerijen toekwam en men inhield, niet toereikende bevonden wierd.

Ik vooronderstel dat deze handelwijze op alle residentien almede plaats gevonden heeft, ofschoon Saparoua als het sterkst bevolkt, en daardoor de grootste hoeveelheid nagelen opleverende eigenlijk het neusje van de zalm was; dit zal dan ook de reden geweest zijn, dat de oud Gouverneur Generaal Siberg, zijnen neef van den Berg als resident van Saparoua bij Uwe Excellentiën heeft aanbevolen '.

Dat de Hoofden en voornaamste ingezetenen eindelijk deze knevelarij moede wierden is niet te verwonderen, vooral als men in aanmerking neemt, dat sedert de doorvaart in de Molukkos

1 Verg. Priangan, dl. I, bl. 205*. - Zie ook aldaar op bl. $318^{*}$ over boeten. 
aan alle de Europesche schepen is moeten worden toegestaan, en dus de smokkelhandel in specerijen open gesteld en niet meer te beletten geweest is.

De ingezetenen van Ceram, Goram en alle verdere daar omstreeks gelegen eilanden, dewelke niet onmiddellijk onder de controle van onze militaire macht en ambtenaren stonden, hadden zeer veel voor boven die, waar het Nederlandsche gezag den inzaạm en vervoer van producten kon verhinderen, en waarvan zij dagelijks door de onderlinge communicatie die er tusschen deze eilanden plaats heeft geinformeerd wierden.

De zugt tot onafhankelijkheid en naar het genot van die zelfde voordeelen bezielde dus reeds sedert langen tijd de ingezetenen.

Oude gewoonten en slaafsche eerbied voor het oppergezag van de Nederlandsche O. I. Compe., hielden hen echter terug, en deed hen dat juk met geduld dragen tot dan in 1796 dit in hunne oogen colossaal bestuur op eene schandelijke wijze aan eene geringe Engelsche scheepsmagt overgegeven wierd, waarmede de illusie van de Nederlandsche grootheid in hunne oogen verdween 1. De ingezetenen dewelke den Christengodsdienst beleeden wierden nog door hunne verkleefdheid aan hunne kerkhoofden terug gehouden om als toen uittespatten: dan die van de Mohamedaansche leer vermeenden dat het tijd was om het juk afteschudden en gebruik makende van de weinige militaire macht die de Engelschen op Amboina hadden agter gelaten (: zijnde als toen ter overmeestering van Banda afwezig:) stonden de ingezetenen der negorijen op de kust van Hitou tegen het Europesche gezag op, en bedreigden voor eenige oogenblikken de Christen bevolking van de negorijen bij het kasteel Victoria gelegen 2; dan spoedig ontvangen versterking van Banda deed deze insurrectie gelukkig afloopen.

Veele der muitelingen verloren hierbij het leven, zoo die in de gevegten omkwamen als dewelke gevangen genomen zijnde, zonder form van proces wierden opgehangen.

Het is nog al aanmerkingswaardig dat onder de laatst genoemden zich hebben bevonden de vader en eenige broeders van Oeloepaha, die in de jongste onlusten als hoofd der muitelingen op de kust van Hitou zich opgeworpen had en die in een der laatste expeditiën, op mijn bevel ondernomen, gevangen genomen en door den Raad van Justitie te Amboina ter dood veroordeeld is.

Door deze gepaste straf-oefening en verdere ferm genomen maatregelen bleef de rust in de Molukkos ongestoord, en wij

1 Zie o. a. Mr. J. E. Heeres, „Eene Engelsche lezing” omtrent die verovering in het tijdschrift van het Kon. Inst. voor de T.-, L.- en V.-kunde, dl. LX (1900), bl. 249 v.v.

2 Verg. hiervóór dl. I, bl. 416. 
namen dezelve in $\mathrm{I}_{80} \mathrm{O}$ in eenen zeer gerusten toestand over.

De - ingezetenen konden zich wel niet begrijpen dat deze overgave zo vriendschappelijk toeging, doch daar Java en Macasser gedurende dien oorlog in onze macht waren verbleven, waarvan zij door de Inlandsche vaartuigen, die vooral van Macassar te Amboina ter handel kwamen, steeds geinformeerd waren geworden, hield de vrees voor het als toen nog bestaande O. I. Compe gezag hen in behoorlijke onderwerping.

Dan ongelukkig barste de oorlog weder spoedig uit, waardoor, de verzendingen van lijwaten, comptanten en verdere benoodigdheden dikwijls door de vijandelijke kruisers onderschept wordende, het bestuur in de Molukkos in de grootste verlegenheid raakte, zoo om de tractementen der militairen en ambtenaren uit te betalen, als om aan de ingezetenen der negorijen het aan hen verschuldigde voor de leverantie van specerijen te voldoen; er schoot dus niets over, als om eenen papiere nood-munt te creëeren, die door geweld gangbaar moest worden gehouden; het gevolg hiervan was dat er bijna niets meer op de passers wierd aangebragt, en de prijzen voor alle eerste behoeftens zeer hoog stegen, waarover de militairen zeer ontevreden waren.

Men nam zijne toevlugt tot gedwongen leverantien van hoenders, harte-beesten, wilde varkens, olij e. a. voor zeer verminderde prijzen.

Hierbij kwam de geforceerde recruteering voor Java, door den Gouverneur Generaal Daendels ten sterksten aanbevolen; de aanmerkelijke verandering in het bestuur, door den Militaire Commandant verantwoordelijk voor de defensie te stellen; rekwisitien van volk en materialen om batterijen aan te leggen, hadden nu geen einde, en waarschijnlijk alles zonder betaling.

$\mathrm{De}$ hieruit voortvloeijende oneenigheden tusschen den Gouverneur Cransen en den Militaire Commandant, rezen zoo hoog dat de Gouverneur Generaal Daendels zich verpligt vond, beiden naar herwaards opteontbieden; de Heer Wieling volgde den Gouverneur Cransen op, en indien die achtenswaardige ambtenaar tijdig genoeg met de nadere bepalingen en verhoudingen betrekkelijk het militair gezag bekend was geweest, zoude zich alles zeer wel geschikt hebben; dan van een zeer zwaarmoedig gestel zijnde, en de gevolgen vooruitziende die men bij de verschijning van vijandelijke schepen te wachten had, bezat hij geene sterkte van geest genoeg, om zich hier tegen te stellen: en in een oogenblik van vertwijfeling maakte hij een einde aan zijn leven, waarmede het oppergezag zoo civiel als militair aan een zeer zwak officier verviel die zich zoo als het $\mathrm{mij}$ is voorgekomen, door zijn ondergeschikten liet regeeren ${ }^{\prime}$.

1 Over gouverneur Wieling schreef landvoogd Daendels d.d. 7 December 
De Gouverneur-Generaal Daendels had intusschen het belang van de Moluksche bezittingen niet uit het oog verloren; vele pogingen wierden aangewend om dezelve van het noodige te voorzien, en een Civiel Landvoogd (Prefect) van eene zeer ampele instructie voorzien naar Amboina gezonden.

Het groot gebrek aan comptanten gaf aanleiding tot eene gedwongen quotisatie van de gegoedste ingezetenen, en tot eene algemeene bezuiniging in de uitgaven.

Men oordeelde, dat de ingezetenen hunne schoolmeesters zelve dienden te onderhouden, en de geringe bezoldiging van deze zoo nuttige en waarlijk behoeftige dienaren, wierd ingetrokken, voor dat de noodige schikkingen voor hun onderhoud waren gemaakt, en deze menschen in het algemeen te hooghartig om van almoesen te leven (: zoo als zij zulks uitdrukten:) leden spoedig gebrek, een onverzettelijke haat tegen het als toen plaats hebbend bestuur was hiervan het gevolg, en daar zij als bedienaren van den godsdienst in hunne negorijen wierden beschouwd, en dus veel invloed hadden, is het niet te verwonderen dat zij hunne gevoelens aan de ingezetenen mededeelden.

1809 aan minister Van der Heim, dat „Het noodlottig uiteinde van den geachten Prefect van Amboina C. L. Wieling, waardoor hij zo wel mijn op hem gesteld vertrouwen als de hoop van alle de zijne te leur stelde", verstoring in zijn reorganisatie-plannen bracht: $D e$ Roo, dl. I, bl. 247 .

Engelhard in zijn Bataviaasch verslag noemt mede als een der beweegredenen tot den opstand de herinneringen aan "de aanwerving van Ambonnesen soldaten tot den dienst op Jara in 1808 en 1809, waarbij schreeuwende extortien en vexatien hebben plaats gevonden, die omstandig vermeld staan in de Memorie door den Gouverneur Wieling overgegeven aan zijn vervanger op Ternaten den Heer Coop a groen, het welk bij deze volkeren voorzeker niet uit het geheugen is verloren. En deze verdwaalde menigte geen onderscheiding kennende tussehen het voorgaande en tegenswoordig bestier, in onzekerheid hebben geverseerd of bij de herstelling van het Nederlandsch gezag niet wederom dusdanige geforceerde aanwerving zoude worden ingevoerd, die ten enemaal onder het Engelsch Gouvernement had opgehouden". - - Bij Riedel, bl. 37, leest men, dat de opstand uitbrak „doordien de bevolking voor de geleverde kruidnagelen niet behoorlijk werd betaald en de toenmalige Resident J. van den Berg op zijn tochten door het eiland de krachtige en gespierde mannen deed opvatten en als soldaat wegvoeren. Het gerucht verspreidde zich tevens, dat alle mannen, in ketenen geklonken, als soldaten zouden worden weggeleid en dat de Nederlandsche regeering Javanen zou invoeren om met de vrouwen des lands te cohabiteeren." Philip Latumahina, een gewezen schrijver van den Resident, verspreidde dat gerucht, boekstaaft mede Riedel. Geruchten, hoe wild ook, kunnen verspreid zijn en zullen ook wel verspreid zijn, doch de aanhef dezer aanhaling gaat oneindig verder. Ik geloof echter, dat de heer Riedel wel wat spoedig losse mededeelingen als feiten heeft aangenomen. 
In deze gesteldheid van zaken en gisting der gemoederen, verscheen eene geringe vijandelijke macht, waarschijnlijk bekend, op eene zwakke verdediging te kunnen staatmaken.

Door het schandelijk gedrag van eenige officieren viel Amboina en de daar onder sorteerende residentiën in Britsche handen, dewelke zich op alle mogelijke wijzen van de genegenheid der ingezetenen trachten te verzekeren, door dadelijk de schoolmeesters hun achterstallig tractement te doen uitbetalen, en alles weder op den ouden voet te brengen, de specerijen met comptanten te voldoen, de lijwaaten voor mindere prijzen aftestaan, geene verpligte leverantien te vorderen, de heerendiensten te verminderen en de betaling der zoo genaamde kwartslieden te verhoogen van een op drie ropijen 's maands; en eindelijk doordien de Britsche ambtenaren groote verteeringen maakten, kwam er veel geld in circulatie, en de ingezetenen kregen eene goede betaling voor hunne producten: deze welvaart wierd nog vermeerderd door het oprigten van een Amboineesch corps soldaten ruim 500 man sterk die eene zeer hooge soldij genoten en zeer goed gekleed wierden.

Het inlandsche bestuur was onder de Engelschen zeer zagt. Wanneer het negorij-volk over hunne Hoofden klagten inbragten wierden deze dikwijls afgezet zonder gehoord te worden; hierdoor verloren de Radja's, Pattij's en verdere Hoofden veel van hun gezag, zij vermogten niet meer te straffen, het volk wierd hierdoor hoe langer hoe losbandiger, de schoolmeesters alleen behielden hunnen invloed.

En eindelijk nadat alle onze bezittingen aan de Engelschen waren overgegaan, en ons vaderland bij het Fransche rijk was ingelijfd, verzuimde men niet om de ingezetenen der Molukkos te verzekeren dat wij als natie niet meer bestonden, en ook nimmer als zoodanig bestaan zouden, dat zij dus voortaan altijd onder het Britsche bestuur zouden blijven.

Dat alle de ambtenaren en geëmployeerden dit verlangden, is ligt nategaan zoo als ook de Europesche officieren en andere officieren bij het Amboineesche corps militairen geplaatst, waarvan zeer veele in de Molukkos getrouwd en zich aldaar gevestigd hadden; dus was de tijding van eene algemeene vrede, van de herstelling der Nederlandsche natie, en eindelijk die van het gesloten tractaat, waarbij de teruggave onzer kolonien bepaald was, niet zeer welkom; een ieder was daarover ontevreden, en dat men de ingezetenen vervolgens op alle mogelijke wijzen van het verwagt wordende Nederlandsch gezag afkeerig heeft trachten te maken, geloof ik voor mij zeker, en wel voornamelijk -door aan hun alle de knevelarijen der vorige Gouverneurs en Residenten te herinneren, en te voorspellen dat de voor hun zo gunstige dispositien betrekkelijk de schoolmeesters, heerendiensten, rekwi- 
sitien etc. dadelijk op den ouden voet zouden worden teruggebragt, dat zij in stede van klinkende munt weder papier zouden moeten ontvangen, dat hunne kinderen weder naar Java als soldaten met geweld zouden worden mede genomen, hun verders beklagende over het harde juk, dat zij andermaal zouden moeten dragen, en hun lot vergelijkende met dat van hunne nabuuren en vrienden de ingezetenen der strand-negorijen op Ceram, Goram en verdere nabij gelegen eilanden, die men als vrij en onafhankelijk van het Europeesch gezag konde beschouwen, en die hunne producten, vooral de specerijen, tegen hooge prijzen aan vreemde schepen konden verkoopen, daar zij heden verpligt zouden zijn de vruchten van hunne arbeid voor de van ouds bepaalde spotprijzen aftestaan, eindelijk hun te kennen gevende, dat de Britsche macht zeker binnen den tijd van drie jaren even als bevorens in de Molukkos weder terug zoude zijn

Ofschoon ik vertrouw dat de voornaamste Britsche ambtenaren en officieren met dese ophitsingen en oproer stokende gesprekken onbekend zijn geweest, is het echter zeker, dat eenige subalterne individus van die natie, zoo als ook zoodanige inlandsche hoofden die bijzonder aan hun verkleefd waren, zich hieraan moeten hebben schuldig gemaakt; men neme slechts in aanmerking dat de muitelingen van Saparoua dadelijk na het veroveren van het Fort Duurstede de Engelsche vlag opheschen, dat de aanvallen tegen het Fort op Haroukou onder een aantal van die vlaggen zijn geschied, dat dezelve dus hun oproerleus was en ik herinner mij niet, dat de Britsche autoriteiten, alstoen nog op Amboina aanwezig, eenige demarches of verklaringen hiertegen gedaan hebben, en het is zeker dat door hen geweigerd is, eenige assistentie te geven, om de verderen voortgang van den gevaarlijken opstand te dempen.

De nadeelige indruk, dien een zamenloop van omstandigheden geduurende ettelijke jaren op de ingezetenen der Ambonsche eilanden tegen het Nederlandsch Gouvernement gemaakt had, wierd nog vermeerderd bij de aankomst van onze geringe militaire macht, voor het grootste gedeelte uit Javasche recruten bestaande, die nog niet gekleed waren, en die men dus bijna naakt op schildwagt zag staan.

De plegtigheden, waarmede de Britsche resident Martin het Amboineesche Corps afdankte, de vleiende aanspraken en uitgedeelde geschenken heeft ook zeer veel invloed, op de gemoederen gemaakt: vooral op die, welke te Saparoua t' huis hoorden, en die bijna alle te gelijk met kruis orangbaays naar derwaarts terugkeerden, en in het voorbij gaan van onze schepen, reeds duidelijk blijken van hunne afkeer tegen ons gaven zoo als mij eenige officieren hebben verzekerd. 
Alle deze afgedankte militairen zoo als ook de Inlanders die in particulieren dienst der Engelschen waren geweest, kregen zoo genaamde burger- of vrijbrieven, waardoor zijlieden niet meer onder de inlandsche negorij-hoofden stonden, en dus als het ware aan hun zelf overgelaten, vooral die op de buiten residentiën 't huis hoorden, en geen middel van bestaan hebbende, moesten zij spoedig voor de openbare rust gevaarlijk worden.

Het ware te wenschen geweest dat commissarissen tot de overname, en wel de Gouverneur der Molukkos in het bijzonder, zich bij hunne aankomst wegens de gezindheid der ingezetenen hadden geinformeerd, en daarna zoodanige maatregelen in tijds hadden genomen, waardoor mogelijk de algemeene opstand, en de daaruit voortgesproten ongelukken, hadden kunnen worden verhoed of voorgekomen.

Dat zij echter van de ontevredenheid van een gedeelte der ingezetenen eenige kennis hadden, blijkt uit hunne missive aan Uwe Excellentien van den i8 April 1l. '.

Onvergeeflijk zijn dus eenige dispositiën door den Gouverneur kort na de overname genomen in de gesteldheid waarin hij zich bevond, en hebben niet anders kunnen dienen als om het reeds smeulend vuur van oproer te eerder aanteblazen; ik herzegge smeulend vuur van oproer, wijl het blijkt dat reeds zeer weinige dagen na de overname hier en daar zamenrottingen hebben plaats gehad, dat er correspondentie is gehouden tusschen de ingezetenen van Hitou en die van de noordkust van Haroukou en waarschijnlijk met die van Saparoua, waarin zij lieden zich onderling met zware eeden verbonden, zich vrij en onaf hankelijk te zullen maken.

Onvergeeflijk is het van de Nederlandsche ambtenaren, dat zij tegen dese zamenrottingen niet gewaakt hebben, en nog onvergeeflijker dat zij hiervan door eenige getrouwe inlandsche hoofden geinformeerd wordende, er geen geloof aan hebben geslagen, door dien zij onoordeelkundig te werk gaande, zich ter bekoming van inligting juist aan de kwalijk gezinde hoofden adresseerden, die alles aanwendden om hun als het ware in slaap te wiegen door voortegeven dat alles in volmaakte rust, en men bijzonder met het Nederlandsche bestuur te vreden was.

Onbegrijpelijk komt het mij voor, dat de resident van den Berg niets van de oproerige bewegingen, die reeds in het begin van Meij op Saparoua plaats gehad hebben, heeft kennis gedragen: dit blijkt uit zijn gedrag, daar hij alleen en onvergezeld te paard naar de negorij Porto is gereden, om zich te informeeren naar

128 April: zie bl. 507. Den $18^{\mathrm{n}}$ kan niet juist zijn wegens in den brief vermelde latere data: zie bl. 518 . 
de redenen waarom een praauw met gerekwireerde houtwerken voor Amboina nog niet was vertrokken, en den laatste door dien ambtenaar gegeven order, schijnt het teeken tot de uitbarsting geweest te zijn; immers is de overmeestering van het Fort Duurstede, en de moord aan alle die zich daarin bevonden daarop gevolgd.

Ik vertrouw Uwe Excellentien als nu eenig denkbeeld te hebben gegeven van den oorsprong des gevaarlijken opstands, onder de ingezetenen der Ambonsche eilanden, kort na de overname dier bezittingen uitgebarsten, en ik neem de vrijheid als mijne gevoelens in dezen te verklaren, dat een zamenloop van omstandigheden tot dezen algemeenen opstand aanleiding schijnen gegeven te hebben.

Dat ik den eersten oorsprong vermeen te moeten zoeken, in de verre gaande knevelarijen der Gouverneurs, Residenten en geemployeerden van het voormalig Nederlandsch Oost-Indisch bestuur, sedert een reeks van jaren, vervolgens heeft het lot van den oorlog deze bezittingen tweemaal (: en wel gedurende den leeftijd van dit geslacht:) in handen der Engelschen doen vallen, op eene wijze, die de ingezetenen niet veel achting en vertrouwen op onze wapenen konde inboezemen.

Hierbij kan men als zeker vooronderstellen dat eenige Engelsche subalterne individus op alle mogelijke wijze hebben getracht, de ingezetenen van het Nederlandsch bestuur afkeerig te maken, en dezelve tot den opstand zelfs schijnen aangespoord te hebben.

En dan eindelijk eenige onoordeelkundige dispositien door den gewezen Gouverneur van Middelkoop kort na de overname genomen (: en waarvan ik bereids in het algemeen verslag mijner verrichtingen aan Uwe Excellentien op den 25 September ll. aangeboden, gewag heb gemaakt:) hebben het smeulend vuur doen ontvlammen hetwelk mogelijk door zagte «schoon ferme maatregelen" had kunnen worden uitgedoofd.

Ik moet echter tot decharge van dien ambtenaar bekennen dat de middelen, die ter zijner dispositie stonden, om den eens uitgebarsten opstand te dempen, zeer beperkt waren; en dat door het ontijdig afsterven van den kapitein Dietz het commando op een zeer zwak officier was vervalien, die in dien verwarden toestand van zaken, den voornoemden Gouverneur van geene de minste assistentie is geweest.

In de volgende hoofdstukken zullen wij nu met het beloop van den opstand nader bekend worden. Een en ander maal haal ik daarbij nog aan een in handschrift bestaande bron, die ik tot dusver naliet te vermelden. Onder de stukken, in dl. I, bl. 343 opgegeven sub $\mathrm{N}^{\circ}$. 315, behoort nog een in het Maleisch geschreven "Rapport. Aau Mijn Heer die Verheven, aanzienlijk is", gedagteekend Porto 13 
November 1817 en geschreven door den schoolmeester van Porto, Strudiex geheeten: het stuk is wel niet geteekend, maar ik heb dit uit andere gegevens kunuen opmaken. "Dit is een op waarheid gegroude uiteenzetting van de aanleiding en het begin van dezen opstand." De heer Habbema had de vriendelijkheid het stuk voor mij te vertalen; de vertaling legde ik in het Rijksarchief nevens het Maleische stuk, toen ik het niet meer noodig had. Zij, die bekend zijn met dergelijke kronieken van Inlanders, zullen zich niet verwonderen, dat ook dit stuk, behalve niet altijd helder, niet veel zaaks is. Echter is geenszins alles onbruikbaar; integendeel, uit mededeelingen, dic van andere zijden vallen te controleeren, data enz., blijkt, dat de schrijver zijn best heeft gedaau betrouwbaar te wezen. Wel jammer is het overigens, dat hij niet in meer bijzonderheden trad, vooral met betrekking tot den moord op de fumilie Van den Berg en ten aanzien van de expeditie-Beetjes. Het rapport loopt van het begin des opstands tot 22 October 1817, maar van den $20^{n}$ Juni springt het ineens op 21 Juli. Ik zal het stuk aanhalen met de woorden Rapport-Porto. Herinnerd zij hierbij, gelijk wij breeder ter plaatse zullen lezen in deel III, dat de Reygersbergen, commandant Groot, in den aanvang van November in de baai van Haria ankerde; dat den $10^{\text {n }}$ November de ingezetenen aldaar hem onderwerping begonnen aan te bieden, en dat onder de personen, die voor dit doel aan boord kwamen, in de eerste plaats behoorde de schoolmeester van Porto. 


\section{HOOFDSTUK II.}

\section{De opstand te Saparoea: 14-16 Mei 1817.}

Het begin des opstands: 14 Mei. - Resident Van den Berg d.d. 15 Mei te Porto gevangen genomen. - Hoofden der rebellen. - De Resident naar Duurstede teruggebracht: 15 Mei. - Bericht van mevrouw Van den Berg naar Ambon: 15 Mei. - Vermeestering van Duurstede door de rebellen: 16 Mei. - Redding van 's Residents oudsten zoon. Het rapport-Porto over den $16^{\mathrm{n}}$ Mei.

Te Ambon had men palissaden noodig. Resident Van den Berg was gelast er hout voor te doen kappen en over te zenden. Deze gedwougen dienst schijnt tot onterredenheid aanleiding te hebben gegeven ${ }^{1}$. Het hout was nochtans gekapt en lag, gereed tot vertrek, geladen in een orembaai te Porto ${ }^{2}$. De Resident, uu gewaarschuwd door de koffiedrinkende njora van Nolot, was niet meer gerust en zond zijn oppasser naar Porto, met last het vaartuig te doen vertrekken en mede te gaan, ten einde den Gouverneur over de loopende geruchten in te lichlen ${ }^{3}$. De oppasser stuitte echter op het samengeloopen volk, dat het vaartuig niet wilde doen gaan, hem mishandelde en gevangen nam.

Dit is het gewone verhaal ran het begin des opstands. Het rapport-Porto dekt dat verhanl slechts in zoover, dat $\mathrm{er}$ in melding wordt gemaakt van het plunderen van de "postprauw" te Porto. Ziehicr den aauvang van het gansche stuk:

Zes mannen, nl. Johannes Matulesi', Nicolaas Patinasaranij, Jeremias Tamaela, Marawael Hattuw, Bastian Latuperissa, Harmanus Latuperissa gingen te Haria alle huizen rond, om de mannen op te roepen, om in het bosch van Haria, genaamd Waehaum, grenzende aan Tiouw en Paperoe, bijeen te komen, om te beraad-

1 Buijskes noemt als voorbeeld van door Van Middelkoop „onoordeelkundig gegeven orders" een besluit d.d. 12 April 1817 tot houtkap.

2 Verg. dl. I, bl. 471. - Bij Boelen.M., bl. 266, leest men, dat Van den Berg een groote orembaai voor 's residents gebruik deed maken: „welk vaartuig, naar men beweerde, de directe aanleiding tot den opstand was geweest, daar de heer Van den Berg dit aan hem nieuw afgeleverde vaartuig niet naar den eisch had willen betalen".

3 Van Doren-M., bl. 18.

4 Deze broer van den hoofdrebel Thomas werd ook gevangen genomen. Ik schrijf nu eenmaal Matulesi - dl. I, bl. 477 - maar anders wordt ook in dit stuk steeds de naam gespeld Matulesia. 
slagen, naar aanleiding van het gerucht, dat de Compagnie menschen zou pressen om als soldaat naar Batavia te gaan '. Daarom hebben die menschen een vergadering gehouden ten getale van omstreeks IOO mannen, en elkaar trouw gezworen. Harmanus Latuperissa is voorgegaan met een gebed en toen zijn zij overeengekomen, om het fort (te Saparoea) te vernielen en allen daarin te dooden. Als iemand zich daaraan onttrok, dan zou hij door de gemeenschap gedood en zijn familie verdelgd worden. Dat was de eerste afspraak op 3 Mei i8r 7 .

Den 9 van die maand, gingen de zes genoemden weer de huizen van Haria langs, om de menschen ter vergadering te roepen. Op die vergadering werd gevraagd wie kapitein wilde worden. Daarop antwoordde Thomas Matulesi: ik zal kapitein worden en ik zal een vloot van orembaais bijeenbrengen, het fort aanvallen en vernielen en den toean Fetor dooden ${ }^{2}$. Er waren toen ruim IOO menschen bij elkaar. Thomas Matulesi ging voor in het gebed en daarna kwamen de aanwezigen overeen, om Djouw (?) radja Siri Sori en patih Haria te dooden, omdat die beide hoofden dagelijks bij den Toean Fetor kwamen ${ }^{3}$. Toen verspreidden zij zich over het eiland en riepen alle mannen op, om bijeen te komen in het kajoepoetihbosch in de wildernis van Saparoea, grenzende aan Siri Sori en Toehaha. Dat was de tweede vergadering, op dezelfde plaats als de eerste.

Op den $14^{n}$ (Mei) vergaderde de geheele bevolking en legde den eed van trouw af. $\mathrm{Na}$ die vergadering begon feitelijk de opstand des avonds omstreeks 9 ure door plundering van de postprauw (orembaai) te Porto. Toen ik hen daarover aansprak en tot viermaal toe vroeg (wat dat beteekende), antwoordden zij niet. Eerst toen ik hen ging uitschelden, zeide een van hen: wij zijn geen menschen van Haria, maar van het eiland '. Ik herkende de menschen niet, want het was een donkere avond, alleen heb ik Pieter Radjawanga herkend. Toen gingen al die menschen gewapend met parang's, schreeuwende, op de tifa slaande en

1 Verg. bl. 573, speciaal de noot aldaar.

2 Toean Fetor $=$ Resident. - De roorstelling van de wijze, waarop Thomas Matulesi het hoofd werd, wijkt af van de bestaande, die ik nader zal mededeelen.

3 Dus, omdat zij voor verraders werden gehouden. Verg. bl. 566 over Kirauly.

4 M. a. w. Wij zijn niet van een bepaalde negorij, maar van het geheele eiland, leden van de gemeenschap. Op bl. 584 zullen wij dezelfde gedachte lezen, dat men den Resident niet te Porto wilde dooden, opdat niet uitsluitend deze negorij verantwoordelijk zou gesteld worden. Men denke er aan, dat het standpunt van den steller van het verhaal moest zijn, om tegenover de Nederlandsche macht, in wier handen hij was, een mooie rol te spelen. 
dansende langs den weg naar Porto ten einde de menschen van daar over te halen om mee te doen. Zij spraken allerlei dialecten, van Hatawano, van Siri Sori, van Oelat, Ow en Boi en zij stelden zich rondom mijn huis en wilden mij dooden. Toen de morgen aanbrak zag ik pas, dat het menschen van Haria waren.

In den vroegen ochtend van den $15^{\mathrm{n}}$ Mei kreeg de Resident bericht van deu opstand te Porto. Hij liet zijn paard zadelen en reed naar de havenplaats, vermoedelijk zich vleiende, dat de vertooning vau de majesteit van het gezag de kerels wel zou doen neerbliksemen. Met scheldwoorden aangeblaft, werd op Van den Berg mede de hand gelegd. Toen het bericht hiervan te Saparoea kwam, ijlde scriba OrNeK te pard, tot ontzet van den Resident, den weg naar Porto op; ik denk — verg. bl. 587 - vergezeld door eenige manschappen. Iu de nabijheid er van, te Hitoöpe een gehucht, dat ik overigens nergens vermeld vind - wordt Ornek door geweervuur ontvangen en in de hand getroffen, " waarop hij onmiddellijk naar Saparoea terugkeerde, om versterking te halen, en door de wapenen het geweld te keeren" 1. "Vergezeld van een twintigtal gewapende burgers, een korporaal eu twaalf Javaansche soldaten", begaf Ornek zich audermaal op den weg naar Porto, "doch toen hij te Hitoöpe aankwam, werd een der Javanen door eenen geweerkogel den arm verbrijzeld, terwijl eene groote menigte gewapeude inlanders op hen afkwamen, waarua zij besloten, terugtrekkende, Saparoea te bereiken" 2 .

Misschien was de overmacht zoo groot gebleken, dat zelfs een heldhaftig voorwaarts schrijden roekeloos zou gebleken zijn. Onder de aanzienlijken in de muitende beude worden genoemd ${ }^{3}$ : de patih van Haria, Jeromeus Lerhoto; de schoolmeesters Risako'ta en STrudiek, door hun ambt, menschen van invloed; al de kapala's

1 Van Doren-M., bl. 19. - Dat wonden van de hand zullen wij bevestigd zien in het rapport-Porto, bl. 587.

3 Het vermelde bij Van Doren.M., bl. 19, van het uittrekken van een korporaal met 12 man, deed bij mij de vraag rijzen of ook op deze hulp betrekking kan hebben een in allerijl door Van den Berg geschreven briefje, dat bij de herneming van het fort d.d. 2 Augustus 1817 door de onzen gevonden is in de kamer, waar het geheele gezin Van den Berg vermoord is en van dezen inhoud was: "Sergeant komt spoedig cito met 12 man met scherp geladen, om mij te verlossen, alles is in oproer." Zie Ver Huell, dl. I, bl. 125 ; Boelen-M., bl. 266.

${ }^{3}$ Bij Van Doren-M., bl. 19. Geen der namen wordt vermeld in het rapportPorto, behalve de patih van Haria, dien men echter niet vertrouwde. Strudiek wąs de schoolmeester van Porto: zie bl. 579 . 
soa ${ }^{1}$ der heerendienstplichtigen van Porto en Haria ${ }^{2}$; Thомиs Pattywala, radja van Tiow; verder Salemba Latoechamalla, gewezen radja van Oelat, onder het Engelsche tusschenbestuur verwijderd en naar Java verbannen, later teruggekeerd en te Porto woonachtig ${ }^{3}$. Daar ook woonde Thomas Matulesi, die weldra het hoofd van den opstand zou worden en van wien Ver Huell, die hem op zijn schip als gevangene van Saparoea naar Ambon bracht, de volgende beschrijving gaf ${ }^{4}$ :

"Thomas Matulesia was een man van ongeveer vier-en-dertig jaren oud, rijzig van gestalte, schraal vau wezen, en een duister uitzigt, dat evenwel niet veel sprekends of vernuftigs had.... Hij was een Amboinees van geboorte en belijder van de gereformeerde godsdienst, burger van Saparoua, en Sergeant-Majoor geweest onder de Britsche inlandsche militie. Eene meer beschaafde opvoeding, zijne bedrevenheid in het lezen, schrijven en eenige militaire kundigheden hadden hem tot hoofd des opstands verheven. Hij was gedurende dien tijd meest gekleed in eene uniform, en versierd met de epauletten van wijlen den Majoor der Genie BeE'TJes, bij de uitbarsting des oproers omgekomen. Hij droeg een hoed met pluimen en eene sleepsabel op zijde. Men had hem dikwijls te paard gezien, van eene bende scherpschutters omgeven, wanneer hij de onderscheiden werken in oogenschouw nam. Hij had den weidschen titel aangenomen van: Panhoelo Pangerang, di atas poelo Honimoa, Haroeka, Noessa Laut, Ambon, Ceram, dan lain jang berikot ${ }^{5}$; dat is: opperhoofd des oorlogs, over de eilanden Honimoa, Haroeka, Noessa

1 Verg. dl. I, bl. 486. De doesoens soa „hebben haar ontstaan te danken aan de verpligte diensten, die de bevolking in vroegere tijden leveren moest": Van Hoëvell, bl. 183.

${ }^{2}$ De opgave is, gelijk medegedeeld, ontleend aan Van Doren-M.; echter leest men er op bl. 14-15: „Het waren geenszins de negorij bewoners, op wie de last der heerendiensten rustte, die het eerst tot muiterij zijn overgeslagen, maar wel de zoogenaamde vrije burgers."

3 Deze ex-radja van Oelat is den $25^{n}$ Maart 1818 met de Wilhelmina naar Java gezonden; in het journaal van dat oorlogsschip wordt hij genoemd: „Jeremias Labuhamaloe (alias) Salemba".

4 Ver Huell, dl. I, bl. 242-244. - Ook een beschrijving bij Van Doren-M., bl. 22-23.

5 Jang berikot toewan Matulisy. Ook bij Van Doren-M., bl. 22, Stuart, bl. 400-401, Kronyk, bl. 357 is alzoo de titel vermeld. Van Hoévell, bl. 12 evenwel opmerkende, dat de generieke benaming Oeliasers niet van inlandschen oorsprong is, voegt er aan toe: „Evenmin is het eiland Saparoea onder den naam van Honimoa, of het eiland Haroekoe onder dien van Oma of Boewang Besi bekend." Als dat juist is, hoe heeft dan Matulesi zich oorlogshoofd van "Honimoa" kunnen noemen? - Verg. noot 5 op bl. 466 over Haroekoe. 
Laut, Amboina, Ceram en nabij gelegen kusten. Aapachtig werd de uitdossing van dezen opstand-generaal toen hij ook een epaulet op zijn borst deed hangen '. De vraag is echter of het wel juist is, ook de mededeeling bij Riedel ${ }^{2}$ over "de mislukte eerste expeditie onder den Majoor der Infanterie P. Beetjes, wiens uniform nog te Haria, van waar de moeder van Matulesi afkomstig was, bewaard wordt"; dat Beetjes geen infanterist was, weten wij, dat het bestuur zou toegelaten hebben de bewaring in de negorij van de uniform des ongelukkigen. als een triumfteeken schijnt ouaannemelijk; ik heb het ook bij geen ander schrijver medegedeeld gevonden.

Matulesi heeft, naar het zeggen ${ }^{3}$, zijn invloed niet vermeerderd door in ongeoorloofde gemeenschap te leven met de gewezen huishoudster van den vroegeren Britschen havenmeester te Ambon, White: Elisabeth Gassier. Elders lezen wij ${ }^{4}$, dat zij het was, die Matulesi overal vergezelde en hem voortdurend tot handelen aanspoorde, zijude "de achtergelatene vrouw van den als soldaat weggevoerden inlander Eliza Titalei", terwijl dit wegvoeren van Inlanders om ze tot soldaat te pressen juist als een mede-oorzaak tot opstand er wordt aangegeven 5. De broeder van mevrouw de generaalsche werd ook een generaał der rebellen. Met invloedrijke familie-betrekking komt men inderdaad ver!

Wat moesten de opgestanen nu met den Resident aanvangen? Natuurlijk dood maken, maar bij nadere overweging achtte men het beter, "den Resident naar Saparoea terug te laten keeren, angezien zij geheel alleev, bewoners van Porto eu Haria, en niet al de bewonèrs van het eiland voor schuldig aan den moord zouden gehouden worden" ${ }^{6}$.

Alzoo werd Van den Berg in den vamiddag van denzelfden $15^{\mathrm{n}}$ Mei door de muiters naar Saparoea teruggevoerd, een lijdensweg. De bende vóór het fort gekomen, stond stil. Matulesi keerde naar Porto terug; Leihoto en Strudiek brachten den gevangene tot den trap en lieten hem toen alleen binnengaan ?. Hier vond hij zijn vrouw met de kinderen en bedienden; voorts Ornek, zoomede 'n $30-40$

1 Boelen-M., bl. 281.

2 Riedel, bl. 37-38.

3 Van Doren-M., bl. 109.

4 Riedel, bl. 37.

${ }^{5}$ Verg. bl. 573 , noot 1 en bl. 581 .

6 Van Doren-M., bl. 19. - Verg. hiervóór bl. 581, noot 4.

7 Op bl. 587 lezen wij, dat volgens rapport.Porto deze twee personen waren de patih van Haria en de schoolmeester van Porto, dat overeenstemt met de op bl. 582 vermelde namen. 
burgers, allen op het vernemen der verontrustende geruchten binnen het fort gevlucht. De rebellen, steeds in getal aangroeiende, waarden er om rond; de invallende duisternis en de vrees voor het geschut weerhielden hen om al dadelijk den aanval te beginuen ${ }^{1}$.

Ziehier wat in het rapport-Porto over dien ongelukkigen $15^{\mathrm{n}}$ vermeld staat; het is het onmiddellijke vervolg op het extract van bl. $580-58 \mathrm{~L}$ :

Den $15^{\mathrm{n}}$ Mei omstreeks 7 ure des morgens ging de Resident te paard van Saparoea en kwam aan het huis van patih Haria om naar het inladen van de voor Ambon bestemde orembaai te kijken. Toen kwamen de menschen van Haria om hem aan te vallen. De Patih liet mij roepen en ik begaf mij dadelijk op weg, maar toen ik bij het huis van Marius Manuhato kwam, zag ik een massa menschen voor het huis van den Patih. Ik ben daarop teruggekeerd, maar toen ik bij de school gekomen was, ging ik weer naar het huis van Patih, waar de Resident was. De Patih van Haria zeide tot den Resident: zou u niet liever naar het huis van den meester gaan. Daarop kwam de Resident in mijñ huis. Toen kwam Johannes Radjawanga en wilde den Resident steken. De Resident vroeg een sabel; ik antwoordde, dat ik er geen had. Toen zeide de Resident: Gijlieden, Meester en Patih, brengt mij naar het huis van radja Porto en hij voegde daarbij: Gij, Meester, wijk niet van mijn zijde; waarop ik antwoordde: ik zal bij u blijven tot in den dood. Toen schreef de Resident brieven, om van het gebeurde kennis te geven te Saparoea, de eene brief werd gebracht door David Berhitu en de andere door Cornelis Nanlohy. Toen verzocht ik den Resident bij radja Porto en patih Haria te blijven, dan zoude ik aan de menschen van Haria vergunning vragen om den Resident naar huis te brengen, want radja Porto en patih Haria hadden geen gezag meer. De Resident keurde dat goed; ik ging toen naar het gemeentehuis van Haria, waar de orang toea Sahuleka als hoofd fungeerde. Ik vroeg hem hoe zijlieden zoo konden doen en toen zeiden zij: het gaat niet uit van ons, menschen van Haria, maar van de bevolking van het geheele eiland. Toen zeide ik tot den orang toea Sahuleka: als dat alles

1 Het geheele verhaal ontleend aan Van Doren-M., bl. 20-22. Alzoo zou mevrouw Van den Berg en haar gezin naar het fort gevlucht zijn. Bij Ver Huêl, dl. I, bl. 126 leest men daarentegen over de muiters: „Zij slepen de ongelukkige met haar van angst gillend kroost naar het kasteel." De mededeelingen zijn soms zeer verward. In een nader te vermelden brief van Engelhard aan Kruijthoff wordt medegedeeld, dat volgens een Saïd, die den $15^{\mathrm{n}}$ Mei des avonds van Saparoea was vertrokken, de beide radja's van Porto en Amet door de rebellen waren vermoord, „omdat zij de Resident van den Berg geborgen hebben en door de binnenlanden naar de Residentie hebben geconduiseert"! dat is dus een geheel andere roorstelling. - Verg. bl. 589. 
van de bevolking van het eiland uitgaat, waarom moet de Resident dan te Porto of Haria gedood worden. Toen liet Sahuleka de orang toea Souhoka en Souissa roepen; in het gemeentehuis gekomen, zeide ik tot de drie orang toea: wij menschen mogen niet eerst berouw hebben en dan zondigen ${ }^{1}$. Dat gezegde brachten de drie orang toea over aan de menschen van Haria, die te Ajer Radja ${ }^{2}$ verzameld waren. Vervolgens keerde ik spoedig naar het huis van radja Porto terug. Toen kwam Lucas Souhoka den Resident bedreigen met zijn parang, zeggende: Wij hebben geen kwaad in den zin ${ }^{3}$, waarom komt dan de schrijver met soldaten op ons schieten 4. Toen ging hij (Souhoka) weer heen. De Resident vroeg: Hebt gij al menschen gekregen (om mij naar huis te brengen). Ik zeide: Wacht u even hier, mijnheer. Daarna ging ik terug naar Haria. Toen kwam radja Oelat Salimba ${ }^{5}$ met Thomas Matulesi en toen ik terugkwam van Haria, ontmoette ik Th. Matulesi voor de deur van de school en hij zeide: Wees maar niet bang toean goeroe en breng mijnheer maar naar huis. Toen liet de Resident hem (?) roepen en kwam hij. De Resident zeide: Breng mij naar huis met den meester en den patih van Haria en twee orang toea Sahuleka $\in$ n Souhoka, een oppasser van de kerk van Haria ${ }^{6}$, Mattheus Hattuw van Porto, Radja Salimba, orang toea Watimung, orang toea Polnaja, orang toea Lucas Sahoetijan, Lucas Waelipattij, Lucas Anakotta, Benjamin Wattimunij, Mattheus Pelamezene, Frans Sijurima, Pieter Wattimunij, Pieter Nanlohij, Pieter Nunlesij, Lucas Marlesij.

Al die menschen brachten den resident tot Ajer Radja, waar de menschen van Haria verzameld waren om den Resident te beschermen ${ }^{7}$. Er waren daar ongeveer 30 menschen met schild, zwaard en lansen ${ }^{8}$, maar zij deden geen kwaad; alleen was er een zekere Tobias Takarija, die lachende tot den Resident zeide: Goede reis mijnheer. De Resident beval de orang toea Sahuleka en Souhoka vooruit te gaan, om patih Tiow bericht te geven van zijn komst en hem te gelasten om menschen van Tiow te zenden om hem (den Resident) te gemoet te gaan en te voorkomen dat hij onderweg den vijand zou ontmoeten. Wij brachten den Resi-

1 Berouw komt te laat of iets dergelijks?

2 De naam van deze plaats is mij onbekend.

3 Of: wij staan toe, dat u ongehinderd weggaat.

4 Verg. bl. 582 .

5 Dus de op bl. 583 , noot 3 bedoelde.

6 Oppasser. Er staat: maringo $==$ heerendienstplichtige.

7 "Peleh" beteekent volgens het vocabularium van Van Hoëvell: verbergen, bedekken, beschutten. 't Was anders een vreemde bescherming !

8 Van aangepunte, in het vuur geharde bamboes. 
dent tot het gemeentehuis van Tiow en eenige burgers, in het geheel 'n 20 man. Patih Tiow deelde aan den Resident mede, dat de Schrijver, Radja Amet en eenige soldaten den Resident waren te gemoet gegaan, maar dat zij beschoten waren en de schrijver gewond was, waarop hij met de anderen naar het fort was teruggekeerd. Ik en patih Haria brachten den Resident tot de poort van het fort onder den cederboom, omstreeks 3 uur des namiddags. De Schrijver daalde af uit het fort en toonde zijn hand, die door een schot van den vijand was gewond, aan den Resident en radja Amet berichtte, dat hij des Residents brief van Porto had ontvangen en dat hij de menschen van Amet had gelast een brief naar Ambon te brengen '. Toen beval de Resident een orembaai te Paperoe gereed te maken, maar de (uitgezonden ?) menschen keerden niet terug en de Schrijver kwam aan den Resident berichten, dat hij (of die menschen) beschoten was (waren) door den vijand uit de kajoepoetihboomen. Toen gelaste de Resident dadelijk , dat een gedeelte van de burgers den weg naar Hatawano, een gedeelte den weg naar Siri Sori, Oelat en Ow, een gedeelte, dien naar Porto, Haria, een ander gedeelte den weg naar Boi zouden bewaken of afzetten, terwijl eenige burgers in het fort zouden blijven. Aan patih Tiow en radja Saparoea beval hij goed wacht te houden in hun negorijen.

Toen eerst zeide de Resident: Meester Porto ga nu maar naar huis en doe uw werk (van godsdienstonderwijzer) zooals gewoonlijk. Toen ging de Resident het fort binnen en bracht met den Schrijver de wapens in gereedheid en radja Amet, zoomede de radja van Oelat, Salimba gingen naar het fort en vroegen kruit aan den Resident. Deze gaf twee patronen per man; toen ging ik met die menschen terug. Bij de negorij Tiow gekomen, werd de patih Haria bang om naar zijn negorij te gaan en keerde naar Saparoea terug, maar ik ging naar Porto, waar ik omstreeks 4 uur aankwam.

Ik last nu weer volgen, wat de publicatiën ons mededeelen. Ongeveer acht uur in den avond van dezen zelfden dag kreeg de Resident bezoek. ANTHONIE RHÉвок behoorde tot een der oudste, steeds in den dienst der Compagnie geweest zijnde familiën van Saparoea. "Hij was een bijzonder sterk, welgemaakt man, van 40 jaren, met forsche, echter goedaardige, wezenstrekken" 2.

De Resident had dezen doorluchtigen afstammeling, wegens een vechtpartij, ook al met rotanslagen laten afstraffen. Rhébok nu scheen dat pak slaag met dankbaarheid te hebben aangenomen, want hij kwam

1 Een brief van den Resident werd niet te Ambon ontvangen.

2 Ver Huell. dl. I, bl. 244. Ook Rhébok voer op Ver Huell's schip den weg ten doode naar Ambon. 
nu, vergezeld van een ander christen, geheeten Latozmaнina, goeden raad geven! Het schouk hun echter gelegenheid den staat van het fort op te nemen. Rhébok wees op het bedenkelijke vau de beweging, waaraan niet alleen het gansche eilaud, maar ook Ambon deelnam; hij beval dientengevolge aan geen geweld te gebruiken, maar met zachte maatregelen den twist in der minne te schikken: bij opstand de gewone raad van menschen, die feitelijk tot de partij behooren! Van den Berg, verheugd over deze komst, drukte Rhébok de hand, betuigde zijn leedwezen over de straf, die hij verplicht was geweest op te leggen en dronk een glas wijn met zijn bezoekers. De Resident, aanbevolen zijude om an de ingezetenen van Siri Sori, die inzonderheid reden van ongenoegen meenden te hebben, een bricf van bevrediging te schrijven, voldeed er aan, terwijl Rhébok zich met de bezorging belastte. Deze, geroepen om het eerste hoofd der rebellen onder Matulesi te worden, bepaalde er zich toe den brief aan een paal op de pasar van Saparoea te plakken. Latoemahina bleef rustig den nacht in het fort doorbrengen.

Alvoreus het zoo ver gekomen was, had mevrouw Vau den Berg gelegeuheid gevonden - wel 'n wonder, dat men daarin nog slaagde, doch het feit staat vast - om een vaartuig naar Ambon te doen gaan. Scriba Ornek, die braaf aan zijn plicht blijkt voldaan te hebben, zoud daarmede een brief aan den Gouverneur; mevrouw Van den Berg een briefje aan haar oom Engelhard, gevende "in de wanhopigste bewoordingen te kennen, dat het geheele eiland in oproer was, en de Indianen alle de Europeanen vermoordden, dat de Resident reeds gevangen was gezet, en in de hagchelijkste omstandigheid verkeerde, en zeker mede een slagtoffer zoude worden, indien er niet dadelijk hulp gezonden werd, om de verwoede Indianen te beteugelen" ${ }^{1}$.

In plaats van zich tot het uiterste te verdedigen, in afwachting van die hulp en alvast het geschut te doen spelen, waar de houding der rebellen voldoende deed vreezen, dat bij hen geen genade was te vinden, liet de Resident in den ochtend van den $16^{\mathrm{n}}$, ongeveer-10

1 Ver Huell, dl. 1, bl. 124. Zoowel daar, als bij Van Doren-M., bl. 26, wordt medegedeeld, dat mevrouw Van den Berg het briefje eerst schreef toen haar man reeds in het fort was, èn dat het briefje gericht was aan gouverneur Van Middelkoop. Het eerste is mogelijk, doch minder waarschijnlijk, omdat dan de Resident zelf wel zou geschreven hebben. Ook wordt daarin geen melding gemaakt van Ornek's briefje, houdende verzoek om 'n 100-tal manschappen en de begrooting van het aantal muiters op 400. Het zenden van deze beide stukken aan de door mij opgegeven adressen, deelt Engelhard mede en zal zeker wel juist zijn. 
uur, de witte vlag hijschen, zeker geen middel om de bezetting aan te vureu. De stroom der muiters zwol er slechts door aan; men drong toenemend tegen het fort op; de oorlogsdeunen werden alom geslagen en geblazen; ladders van bamboe, ter beklimming van de muren, gemakt. Onderwijl verzamelde zich 'n 50 tal achter den ringmuur van het residentie-huis, zoo om een hoofd te kiezen als om den aanval te bepalen. Een soa-hoofd van Toehaha, tevens "kapitein der burgerij", stelde Matulesi als leider voor, omdat door Matulesi te Porto was voorgebeden. De vergadering nam dit met algemeeue stemmen aan, maar de aldus benoemde had zich - nog zoo dom niet, wanneer hij de waardigheid begeerde - achteraf gehouden ęn wachtte te Porto den gang der beweging af. Vier rebellen makten zich alzoo derwarts op, ten eiude hem net de beslissing bekend te maken en uit te noodigen dadelijk over te komen. $\mathrm{Hij}$ voldeed aan den oproep en nam de benoeming met weidschen titel aan, nadat men hem onvoorwaardelijke gehoorzaamheid had beloofd '.

$\mathrm{Nu}$ ook kon dadelijk tot den aanval overgegaan worden. De Resident dit ziende, verscheen op de borstwering, wuivende met een witten zakdoek, terwijl hij zijn onderhebbenden verbood tegenstand te bieden. Een rebel — "sommige beweren" Matulesi zelf ${ }^{2}-$ legde zijn geweer aan en trof den Resident in de rechter dij: Van den Berg stortte naar binnen. De twaalf Javaansche soldaten - de sterkte der bezetting — zich verbeeldende, dat de Resident gesneuveld was - het verhaal is niet geheel duidelijk ${ }^{3}$ - sprongen onmiddellijk over de batterij, wellicht om te ontvluchten, hetgeen dan toch een onmogelijk pogen zou geweest zijn. In ieder geval werden zij dadelijk afgemaakt. $\mathrm{Nu}$ werd de beklimming van het fort algemeen; de daarin zich bevindende burgers zochten een goed heenkomen. Orvek wist nog in een prauwtje te komen, werd echter achterhaald, ook natuurlijk afgemaakt, en, aan wal gebracht, in stukken gehakt. Hetzelfde lot trof zijn broeder en den op bl. 585, noot ] vermelden radja van Amet. Den nog in leven zijnden Van den Berg sleepte men naar den paal, waaraan de klok van het fort hing; daaraan vastgebonden, trad een schoolmeester voor, die een gebed deed, waarna de Resident met kogels doorboord werd.

1 Bij Van Rees, bl. 77-83, een dramatisch ingekleed verhaal van deze vergadering! - De voorbidding door Matulesi, ook op bl. 581.

2 Van Doren-B., dl. I, bl. 303.

s Al wat ik hier mededeel over den moord op de familie Van den Berg, is ontleend aan Van Doren-M., bl. 23-25, die echter weinig critisch is. 
Het moeten niet te beschrijven oogenblikken geweest zijn voor mevrouw Van den Berg, die "in het fort in een der localen tot berging der kruidnagelen was".1 , en haar vreeselijk lot wel te gemoet moest zicn; zij had hare kinderen bij zich; zij was bovendien in verwachting. De moordtooneelen van 1651 , waarmede de $5^{\mathrm{e}}$ Ambonsche oorlog aanving, en die Rumphius in "grouwelijkheid van deze vloek verwanten" zeide te omschrijven "tot waarschouwing vande naarkomelingen", herhaalden zich. Destijds, in 1651 was gezaghebber op Manipa Jan Comans, doch bij het uitbreken van den opstand bevond hij zich te Ambon, terwijl zijn vrouw alleen thuis bleef. "Een parthij honden" drong naar binuen, viel haar aan en sloeg ze dood "voorts het doode lighaam schandelijk mishandelende, de borsten afsuijdende en zeggende datse een hollands verken in stukken kapte... De vermoorde vrouw had twee dogtertjes, diese gevangen namen, maar van het eene korts daar na door quetsuure en ongemak gestorven is, het andere hebbense na Boero aan quimelaha Hassij tot een teken van triumph gezondeu" 2 .

Mevrouw Van den Berg onderging nu een gelijk lot. De rebellen hebben haar, naar het schijnt, bij het lijk van haar man gesleept, en daar evenzeer vermoord en op onbeschrijfelijke manier mishandeld; de kinderen werden mede in stukken gehakt op één na, dat wel als door een wonder, schoon ernstig gekwetst, den dood ontkwam; het werd de stamhouder van de familie, die zich naar deze ongelukkige gebeurtenis zou noemen Van den Berg van Saparoea; welluidender en minder rechtstreeks naar deze rampzalige gebeurtenissen terugvoerende, ware de bijuaam tot Duurstede geweest ${ }^{3}$. Ook s Residents broer, die alzoo mede naar Saparoea schijnt gegaan te zijn, zou tot de omgekomenen hebben behoord +; daar ik het echter niet in de officieele stukken of in de particuliere brieven vermeld vind, wèl daarentegen in later gedrukte publicatiën, rijst twijfel aan de juistheid ervan. Verder werden slachtoffers de commandant

1 Van Doren-B., dl. I, bl. 303, noot.

2 Rumphius, dl. II, bl. 12 en 13.

${ }^{3}$ Verg. dl. I, bl. 367. De eenigszins zonderlinge wijze, waarop Van Doren soms zijn verhalen geeft, treedt bij het verhaal, dat de kinderen „aan stukken werden gehouwen", op typische wijze aan den dag; want er staat op bl. 25 Van Doren-M. een noot van dezen inhoud: „Door deze omstandigheid was het dat een van hare kinderen eenen wissen dood ontkomen is." - Overigens een gelijkluidend verhaal van de wijze, waarop Van den Berg en zijn gezin vermoord zijn, bij Ver Huell, dl. I, bl. 125-126.

4 Van Doren-M., bl. 25. 
van het fort, een sergeant; twee Europeesche korporaals, een Europeesche kanonnier en een dito flankeur, een Pool; welk een verleden moet deze man gehad hebben om hier zijn dood te vinden!

De muiters haalden daarna alles in de residentswouing onder den voet. Zoo was het einde van het bestuur van een man, "die door eene verkeerde handelwijze aanleiding tot deze gruweldaden gegeven had" ". Het in leven gebleven kind had het rechteroor door midden gekapt, een grooten houw over het hoofd gekregen en was evenzeer voor dood achtergelaten. Toen alles stil om hem geworden was, kwamen eenige Inlanders de plats van het moordtooneel nog eens opnemen. Hij lichtte het bebloede hoofdje op en voegde hen toe: "Goea belom mati." Er werd van deze ontdekking aan Matulesi kennis gegeven. Tegen hen, die het kind alsnog wilden slachten, voerde hij nu aan, dat God getoond had het in het leven te willen doen houden en men 's Heeren gramschap op zich zou laden, indien aan dien wil geen gehoor werd gegeven. Alzoo bleef het schaap in het leven, ook zelfs in de dagen toen er voor de opstandelingen geen toekomst meer zou zijn ${ }^{2}$. Het eerst, dat men van deze buitengewone redding hoorde, was den $22^{\mathrm{n}} \mathrm{Juli}$, toen commandant Groot

1 Ver Huell, dl. I, bl. 125.

2 Volgens Van Doren-M., bl. 25-26, nam de op bl. 566 vermelde Sовнока den jongen in bescherming, toen men hem ontdekte. Bij Matulesi gebracht, verwierf Arnold Pattrwant, die zich bij het beklimmen der borstwering van het fort onderscheiden had, de toestemming voor het kind zorg te doen dragen; deze vertrouwde het toe aan zijn broeder Salomon Pattrival, die volgens Van Doren, later tot radja van Tiow is verheven; hij woonde echter destijds "te Ricla” „bij wien het tot de komst van den Schout-bij-nacht en Kommissaris Generaal Buijskes gebleven is": dat Ricla kan ik niet thuis brengen. - Ver Huell daarentegen verhaalt bl. 239-240 - wat hem wel te Tiow op het nader te vermelden bivak in November 1817 zal nedegedeeld zijn - dat een vrouw op het hooren van "goea belom mati" naar het kind toeging. Deze had haar man geroepen, die het opperhoofd der rebellen verzocht, om het kind te mogen behouden. Matulesi zou dit toegestaan hebben onder de woorden "tra verdoeli ambil itoe babi poeti". De kwetsuren waren toen dadelijk verbonden geworden. „Sedert dien tijd, had het bij hen in het woud geleefd." - Soehoka werd wegens goede trouw aan het Nederlandsche gouvernement, toen in 1829 een complot van Amboineezen werd ontdekt om het fort Nieuw Victoria af te loopen, vereerd met een getuigschrift van tevredenheid en verheven tot soa-hoofd in de negorij Haria: Van Doren-M., bl. 25, noot $\uparrow$. - Bij Riedel, bl. 37, leest men, dat het kind gered werd "door zekeren Paulus Pelupesi, vader van den tegenwoordigen Radja van Ou". Men kan zich trouwens wel voorstellen, dat vooral in de latere herinneringen, ieder gaarne voor een afstammeling werd gehouden, van den redder van het kind! 
van de Reygersbergen, nevens het koloniale vaartuig Iris in de golf van Hatoewano gelegen ', den vorigen dag de negorijen aldaar had getuchtigd. Wij lezen toch in Groot's scheepsjourual op den ochtend van dieu $22^{\mathrm{n}}$ : "Ten 6 uur kreeg ik van de Iris aan boord een inlander van het eiland Haroeka, welke aldaar ${ }^{2}$ in de gepasseerde nagt aan boord was gekomen; deeze iulander melde mij, dat hij van Radja Nollot was gezonden ${ }^{3}$ om mij kennis te geven dat het volk van Hatowano van intentie waare om vrede te maken, en dat het oudste kind vau den gewesene resident, wijlen den Heer van den Berg nog in leven was, waarvoor hij 's maandelijks geld tot onderhoud gaf. Van mijn kant geen reden vindende om hieraan geloof te kunnen hegten, genoemde Radja een der opperhoofden van het oproer zijnde, liet ik den inlander provisioneel in de boeijen sluiten om hem van tijd tot tijd uit te hooren." - De bode bleek inderdaad niet te vertrouwen.

Sinds gingen ettelijke maanden voorbij; eerst toen wij den opstand meester waren en medio November 1817 te Tiow bivakkeerden, $\mathrm{kwam}$ een talrijke zich overgevende bende het kind medebrengen. Het had alleen een hemdje aan en was zijn Hollandsch geheel vergeten; overste Ver Huell, er tegenwoordig, nam het tot zich en voerde het later mede uaar Soerabaja, waar het aan zijn bloedverwanten werd toevertrouwd 4 .

De lijken der op dien noodlottigen $16^{\text {n }}$ Mei gevallen slachtoffers werden den volgenden ochtend rechts van den vermelden trap van het fort begraven.

Het rapport-Porto bevat over de allertreurigste geschiedenis van den $16^{\mathrm{n}}$ Mei zeer weinig, doch dit weinige doet ons voldoende de meening van den inlandscheu schoolmeester kennen, dat de Resident onder de omstandigheden, waarin hij nu geplaatst werd, niet flink en waardig genoeg is opgetreden. Ziehier, wat hij over het fort ad 15 op 16 Mei mededeelt; het volgt alweer onmiddellijk op mijn laatste anhaling uit dat stuk op bl. 585-587 :

Dien nacht werd het door de geheele bevolking van het eiland omsingeld en den $16^{\mathrm{n}}$ des morgens omstreeks 6 uur kwam Thomas Matulesi met de menschen van Porto en Haria zich bij de menschen

1 Verg. dl. I, bl. 473.

2 D. w. z. op de Iris.

3 Verg. bl. 566.

4 De geschiedenis van het terugvinden van het kind te Tiow vindt men bij Ver Huell, dl. I, bl. 239-240; de zeer aantrekkelijke schetsteekening ervan door Ver Huell is echter gebonden, althans in het exemplaar ter Koninklijke Bibliotheek te 's-Gravenhage, vooraan in dl. II. 
voegen, die het fort bedreigden, om de versterking te vermeesteren, maar vóór zijn aankomst had de Resident de witte vlag doen hijschen en zich op allerlei wijze vernederd ${ }^{\mathbf{1}}$, want de Resident was een orang baroe en had de bevolking van het eiland nog in het geheel geen kwaad gedaan ${ }^{2}$. Maar zij (de opstandelingen) wilden van geen onderhandelingen weten en omstreeks to uur vroeg Th. Matulesi: Wie zal de Kapitein zijn bij de bestorming van het fort? Niemand antwoordde, ook niet toen hij dat ten tweeden male vroeg. Toen zeide hij: dan zal ik maar het bevel voeren bij de bestorming. Des middags om I 2 uur liet de Resident een brief naar beneden brengen, waarin vredesonderhandelingen werden voorgesteld, maar de opstandelingen wilden daarvan niets weten en omstreeks 3 uur werd de kota bestormd en veroverd.

Den $I 7^{\mathrm{n}}$ Mei liet Thomas Matulesi de Radja's en Patihs roepen naar Saparoea om voor het begraven van de lijken te zorgen.

1 "dan tondjokh segala pry karindahan", dus: zich nederig betoond.

2 Verg. bl. 569, noot 1. De bedoeling kan echter ook wel zijn, dat Van den Berg de menschen niet kende en dientengevolge geen geweld had willen gebruiken. 


\section{HOOFDSTUK III.}

\section{De overwegingen tot onderdrukking van den opstand: 16 Mei.}

Uitstel der verzending van specerij-ladingen naar Batavia. - Bericht van den opstand te Ambon. - Houding van Ver Huell. - Het bevel tot het aanhouden van den Evertsen. - De Iris. - Engelhard's mededeeling over het aanhouden van den Evertsen.

De Moluksche commissie had alle reden tot tevredenheid gehad over de resultaten harer onderhandelingen met het afgetreden Britsche bestuur. Oordeelkundig was zij opgetreden; dank daaraan werd ook de beschikking gekregen over een zeer ruime hoeveelheid specerijen. Aanvang Mei schreef Engelhard particulier den Gouverneur-Generaal over het succes. Het plan was, deelde hij mede, den $10^{\text {n }}$ of den $15^{\mathrm{n}}$ de Nassau en de Reygersbergen naar Java terug te zenden, volgeladeu met notenmuskaat, kruidnageleu en foelie, "niet twijffelende of de ontvangst van dat product zal aangenaam zijn en tot stijving van de cassa a costij konnen strekken". De dus te verkrijgen en inderdaad welverdiende goede naam ging met den opstand verloren. Voor een goed deel werden nu de op de in verzet gekomen eilanden verzamelde oogsten vernield, voor het overig deel kon, voor het transport, van een terugzending der oorlogsschepen uu geen quaestie zijn.

De verpletterende tijding, afgezonden door scriba Ornek en mevrouw Van deu Berg, had den $16^{\text {n }}$ Mei Ambon bereikt; resident Martin heeft haar er ook nog vernomen, daar hij den volgenden dag onder zeil ging ${ }^{1}$. Dadelijk ook was de beweging

1 Verg. dl. I, bl. 430. - In Ver Huell, dl. I, bl. 124 leest men: „De Britsche Gouverneur Martin ging den $17^{\text {den }}$ Mei nar zee. Ik bevond mij dien zelfden dag aan het Gouvernementshuis in het kasteel Nieuw Victoria, toen de Gouverneur Van Middelkoop een klein briefje ontving van de Echtgenoote des Residents van het eiland Honimoa, den Heer van den Berg." Deze mededeeling over de ontvangst op den $17^{\mathrm{n}}$ is niet juist; wel wat Engelhard schreef: ${ }_{n}$ Den $17^{\mathrm{n}}$ Mey jl. heeft de Gouverneur Martin Amboina verlaten. De dag te voren hadden wij narigt erlangd, van het doorbreken van de onlusten op Sapparoua." In overeenstemming hiermede wordt in Tïdschr. Indië, bl. 339 de datum van den $16^{\mathrm{n}}$ als ontvangst opgegeven, doch daarbij wordt vermeld, dat scriba Ornek zelf het bericht kwam brengen, dat evenzeer onjuist is. De verkeerde datum van den $17^{\mathrm{n}}$ staat ook vermeld bij Stuart, bl. 390-391. 
naar het eiland Ambon zelf overgeslagen. Onder die omstandigheden zijn de autoriteiten, in de eerste plaats Commissarissen, ten einde, raad geworden, gelijk wij in dl. I op bl. 528 lazen.

De persoon, die onmiddellijk te Saparoea wilde doen optreden, zonder een oogenblik te verliezen, was Ver Hurct. In hem vinden wij een hoogheidsgevoel, dat boven de gewone menigte doet uitsteken, zonder anmatigend te maken; den moed der verantwoordelijkheid, die ontspringt uit een voornaamheid van de ziel, "welche dem Feldherrn eigen sein musz, und welche sein ganzes Wesen adelt" ${ }^{1}$. En dit treft mij niet alleen hier, in het midden van deze platte omgeving, maar ook in den tragischen strijd, wanneer hij tegenover de meeuingen van Buijskes en Elout, den schipbreuk lijdenden Evertsen op de terugreis naar Holland, nog in behouden haven meent te kunnen brengen ${ }^{2}$. Ver Huell wenschte dadelijk met zijn schip naar Saparoea te zeilen en het fort te bezetten ${ }^{3}$. 'Zeker, er bestond bezwaar tegen, eeusdeels gelegen in de grootte van het vaartuig, anderdeels in het jaargetijde. De Oostmoesson was ingetreden en deze is in de Molukken het regen-, het stormen anbrengeud seizoen, loopende gemeenlijk van Mei tot medio September; de zee is dan vooral onstuimig teu zuiden van de Oeliasers ${ }^{4}$. In de stukken, in de scheepsjourualen van de nu komende dagen leest men ook herhaaldelijk incidenteel, dat de kwade moesson in alle kracht woedde. Waar echter commandant Ver Huell niet schroomde die bezwaren te trotseeren, waar er alles te zeggen viel voor het dadelijk redden der ongelukkigen, voor een snel onderdrukken van den opstand, waar het ontzetten der in het nauw gebrachten, wier treurig lot op den $16^{\mathrm{n}}$ men niet kende, gebiedend een onverwijld handelen vorderde, kan slechts de afwijzing van het aanbod haar verklaring vinden in een niet te genieten flauwhartigheid. Liever dan met Ver Huell mede te gaan, werd gehoord naar resident Martin, naar havenmeester White, naar den commandant van den Britschen compagnieskruiser Nautilus, allen zeer zeker in gemoede raadgevende menschen, maar die de bedreiging van het Nederlandsche gezag uit een auder oogpunt moesten zien dan de Nederlandsche bestuurders. Ook commandant Sloterdijk,

I Bl. 59 van "Das Volk in Waffen" door Colmar Freiherr v. d. Golz (5॰ druk, 1899), een in vele opzichten mooi boek.

2 Ver Huell, dl. II, bl. 164-174 en 243-247.

s Ver Huell, dl. I, bl. 129.

4 Zie Van Hoïvell, bl. 13-15. 
wiens stem hier van zooveel gewicht zal geweest zijn; deelde, naar het schijnt, iu de algemeene gedruktheid; deskundigen als Buijskes hebben hem verantwoordelijk gesteld en hij zelf heeft die verantwoordelijkheid ten slotte wel zéér gevoeld ${ }^{1}$.

Ver Huell had aan de door hem bijgewoonde vergadering, die terstond op de ontvangst van het bericht was te zamen geroepen, de order weten te ontlokken om naar het bedreigde eiland te gaan. $\mathrm{Hij}$ was dientengevolge naar boord teruggekeerd en druk bezig zich tot vertrek gereed te maken, toen hij tegenbevel kreeg ${ }^{2}$. Engelhard heeft hierover in zijn schrijven aan Buijskes, gedagteekend Ambon, 29 Mei 1817, het volgende geleuterd: "Met de scheepen Evertzen en Nassau, hoewel bezeild ook, kan niets worden aangevangen, in deze vaarwateren en in dit jaarsaisoen; Commissarissen hebben het gevoelen van de Gouverneur Martin, den Havenmeester alhier Waith en de Capitein van de kruisser Nautulus ingenomen of het geraden zoude zijn een der linieschepen naar Saparoua af te zenden, dog hebben zulks als uit eene mond afgeraden, en de exempelen aangehaald van de door de Engelsche geledene verliesen op de cust van Laytimor, en gevaren waaraan onderscheidene van hunne scheepen blootgesteld zijn geweest. Zij hadden daarom wel gewenscht, dat de brik Java met de cannonneer boten alhier was angekomen, dit zoude eene geheele verandering in de zaak gemaakt hebben. En het Gouvernement zoude bevreid zijn gebleven van de ongelden, die nu gemakt zijn moeten worden." Men ziet het, dat Eugelhard altijd een soort van wijsheid er bij weet an te knoopen; men zal zich nog in den Oost-moesson kunnen bevinden om aan den dag te doen treden, dat met dergelijke schepen wel degelijk iets viel aan te vangen!

De autoriteiten hadden het oog gevestigd op een onzer kleinere oorlogsvaartuigen de Iris. Elders deelde ik mede ${ }^{3}$, dat dit tot de expeditie van C. C. G. G. behoord hebbende schip bestemd was om na aankomst in Indië, deel uit te maken van de aldaar te scheppen Koloniale Marine. Door den kapitein t/z A. PooL was dientengevolge het commando den $30^{\mathrm{n}}$ September 1816 overgedragen aan den kapiteinluitenant Groot, na de equipage op het halfdek in een korte

1 Zie ook de noot 1, bl. 269-270 Boelen-M, van den onder deskundig toezicht gewerkt hebbenden bezorger van het Memoriaal, over die "grootste fout", waarvan "in de eerste plaats de Kapitein ter zee Sloterdijk de verantwoordelijkheid (droeg)".

2 Ver Huell, dl. I, bl. 129.

s Teruggave, bl. 275. 
aanspraak bedankt te hebben voor betoonden ijver, welwillenheid en goed gedrag in den tijd, dat hij haar chef was geweest. De afgetreden commandant kreeg vergunuing met den koopvaarder Elisabeth naar Europa terug te gaan. Op den 29n Mart 1817 kwam hij behouden in het vaderland aan, "Gode dankende voor deze volbragte en behoudene rijze", besluit het door hem naar Nederland medegenomen scheepsjournaal van de Iris $^{1}$.

Het schip had vervolgens commissaris Van Boekholtz met troepen en den commandant Meijer naar Bandjermasin overgebracht, waar ons gezag mede opuieuw gevestigd moest worden. Den $16^{\mathrm{a}}$ November 1816 verliet de Iris daartoe Batavia; den $1^{\mathrm{n}}$ Januari 1817 werd door den sultan het contract met Van Boekholtz aangegaan, waarbij het Nederlandsche gezag over deze streek van den Archipel werd erkend. Sinds was de Iris ter bekruising naar de Molukken gezonden en had zij den 21 $1^{\mathrm{n}}$ April 1817 de baai van Ambon bereikt; doch wind en stroom dreven haar terug, zoodat ze eerst den $27^{\mathrm{n}}$ d. a. v. ter reede ankerde, echter geheel gehavend, "in reddeloozen staat", schreef Engelhard, zoodat ze aanzienlijke herstellingen moest ondergaan, alvorens dienst te kuunen doen ${ }^{2}$. De commandant was een naamgenoot van den gewezen bevelhebber A. Pool, de kapiteinluitenant t/z. M. PooL. Zoo althans schrijft Ver Huell den voornaam ${ }^{3}$; $\mathrm{ik}$ vind anders in de verbalen van den Gouverneur-Generaal een besluit d.d. 23 Januari 1817 No. 4, waarbij de kapitein-luitenant bij de Koloniale Marine I. M. Pool "uit bijzondere consideratiën" de rang werd toegekend "van luitenant-kolonel bij de armee te lande"; in hoever deze een naamgenoot van M. Pool is, dan wel daarmede dezelfde persoon bedoeld wordt, kan ik niet uitmaken ${ }^{4}$. In ieder geval zal de commandant niet altijd tot genoegen van den bevelhebber van het oorlogsschip de Reïgersbergen ageeren, zoodat wanneer beiden werkzaam zijn in de wateren van Saparoea, de samenwerking nogal eens te wenschen overliet.

1 Verg. dl. I, bl. 341.

2 Zie dl. I, bl. 518.

3. Ver Huell, dl. I, bl. 123.

4 De namen worden, ook in de besluiten, althans in de verbalen, en in de dagbladen zoo onnauwkeurig soms geschreven, dat men er dikwerf op een dwaalspoor door komt. Zoo vind ik steeds als commandant van de Iris, zoolang het vaartuig nog deel uitmaakte van de Nederlandsche zeemacht, vermeld A. Poos; maar in het souverein besluit van 1 Januari $1815 \mathrm{~N}^{\circ} .45$, waarbij bepaald werd, dat de commissie Nahuijs c. s, , na de schipbreuk van de Arinus Marinus, zou varen met de Iris - Teruggave, bl. 246 - las ik als commandant aangegeven K. L. G. A. PooL. 
Om te beginnen, was het een ramp, dat het vaartuigje geheel ontredderd te Ambon het anker liet vallen, want toen het bericht van den opstand te Saparaoea Ambon bereikt had, beschouwde men de Iris als het eenige oorlogsvaartuig, dat niet te groot was om in dien tijd van het jaar de baai van Ambon uit- en die van Saparoea binnen te varen. Bij gemis alzoo van een geschikt oorlogsvanrtuig, nam men voor de expeditie naar Saparoea zijn toevlucht tot open inlandsche, niet bewapende prauwen, waarop de troepen zeer hebben geleden en die tot de verdediging en aanval zelve niets konden bijdragen. Eerst den $21^{\mathrm{n}}$ Mei was de Iris onder zeil om de expeditie, die intusschen den $17^{\mathrm{n}}$ t. v. vertrokken was, te volgen; maar ze had de baai van Ambon nog niet verlaten, toen de schrikverwekkende tijding $\mathrm{kwam}$, dat de expeditie door de opstandelingen was vernietigd: de korvet werd daarop weer aangehouden.

Dit deed Engelhard in zijn Bataviaasch verslag nader schrijven: "De omstandigheden hadden niet toegelaten de korvet Iris voor den $21^{\mathrm{n}}$ in den morgen te doen wegzeilen; ze was juist onder zeil toen dit bericht $\mathrm{kwam}$, hetgeen aanleiding gaf om de korvet, die even ter halve afstand uit de baai gevorderd was terug te roepen, met oogmerk om van dit vaartuig naar tijdsomstandigheden gebruik te maken, als zijnde het eenige tot dienst bij de hand, alzoo het afzenden van een der linieschepen naar Saparoea in het tegenwoordig jaargetij ten hoogste onraadzaam was, als blootgesteld op de kust van Laytimor, dat een lager wal was te vervallen, waarvan gedurende het Engelsch bestuur meer dan een voorbeeld was.

"Vandaar dat $\mathrm{i} / \mathrm{d}$ conferentien van 16 en 18 Mei wierd acht geslageu op advies van Gouverneur Martin en gesterkt door dat v/d havenmeester van Amboin Waith besloten was om geen der linieschepen aan de wisselvalligheden $\mathrm{v} / \mathrm{d}$ moesson bloot te stellen."

Men krijgt echter een anderen kijk op die omstandigheden, waar Ver Huell schrijft ${ }^{1}$ : "Men wilde de hoofdplaats van den bijstand van een der groote schepen niet ontblooten." En verder: "Ik kreeg nu bevel, om met het schip even voorbij de zuidoostpunt van het kasteel te gaan liggen, derhalve vóór het voornaamste gedeelte van de stad, en de batterij met scherp te laden, om, in geval van onverhoopt oproer, dadelijk krachtdadig te kunnen handeleu." Met de vrees voor zichzelf te Ambon is men eigenlijk niet voor den dag durven komeu.

1 Ver Huell, dl. I, bl. 129. 


\section{HOOFDSTUK IV.}

\section{Organisatie van de expeditie tegen Saparoea: 16-17 Mei.}

Gedwongen levering van orembaais. - Houding van overste Kraijenhoff.

- Beetjes als expeditie-commandant. - Samenstelling der expeditie.

- Haroekoe het uitgangspunt der expeditionnaire vloot. - Het reizen met orembaais.

Wij lazen, dat de te Ambon liggende livie-schepen ter verdediging van de hoofdplaats werden noodig geacht en de Iris van de Koloniale Marine niet in staat was dadelijk te vertrekken. Uit dien hoofde werd besloten, dat een expeditie naar Saparoea zou gezonden worden met inlandsche vaartuigen, orembaais, kora-kora's. Voorheen rustte op de negorij-bevolking de last om ze ten dienste van het gouvernement te gebruiken, hetzij voor de jaarlijksche inspectie- of hongitochten ', hetzij voor andere behoeften. Toenemend werd het een hoogst drukkende verplichting, naar aanleiding waarvan Rumphius o. a. over 1631 noteerde 2: "De Juwoonders van de oeliassersche Eijlanden begosten omtrent desen tijd in 't Generaal te murmureren over de gedurige travaljes die se onder de onse uijtstonden als hebbende in ses maanden 3. reijsen met haere Corcorren ter zee geweest en qualijk zoo lange 't huijs dat haere kleeren hadden mogen droogen, zoo datse hun ook lieten verluijden, liever den brand in haer eijgen Concorren te willen steken als langer zoo gekwelt te sijn; de Christenen van Oma hielden hun uijterlijk nog stil, maer de mooren van het gespanschap Hatoeaha vielen opentlijk de Ternataanen toe zeggende datse zoo geck niet meer wilden zijn en haere Concorren die hun soo veel Geld kosten in onze dienst

1 Gouverneur Houtman voer in 1607 "met d'Hongij of oorlogs magt van des Casteels Correcorren als meede die van Hitoe en Loehoe" uit ter herwinning van een paar plaatsen, in verband waarmede men leest bij Rumphius, dl. I, bl. 26-27: „Van die tijd af, is de gewoonte gebleeven, dat de Gouverneurs Jaarlijks eens met de Gezamentlijke magt der Correcorren uijttrecken, soo oin alle verschillen op de afgeleegene plaatsen af te doen, als om den Jnlander te gewennen hun togten vaardig en haar Corre Corren gereed te houden." - In Valentijn, „Oud en Nieuw Oost-Indiën”, dl. II, een aardige plaat van een hongi-vloot.

${ }^{2}$ Rumphius, dl. I, bl. 81-82. 
verspillen, waer toe wij niet een stuiver wilden Contribueeren." En als er in 1636-1637, een geduchte opstand uitbreekt over Ambon en de Oeliasers, die natuurlijk in bloed en verwoesting moest worden gesmoord, dan wordt door "den armen Jnlander" ter verontschuldiging gewezen op den harden dienst als pagaaiers: "alzooze zoo gauw niet te huijs gekomen waren off dadelyk weder tot pangaaijen gevordert wierden, ondertusschen hare landen onbebouwt, haere vrouwen en kinders te huis hongerig zitten bleven"; "dat het gestadig pangaeyen by dag en Nagt hun lastig viel"; "dat alsse de Corcorren afsetlen, eenige scheppers mauqueeren, als dan door de Nederlandsche officiers met den bloten degen overboort gejaagt wierden om die te roepen", mede verzoekende "Datse van de officieren en zoldaaten op haere Corcorren varende, niet mogten gescholden worden". 't Mocht niet baten: "Deze Luijden uijt goede meninge deze poincten van haere beswaeringe voorstellende ontfingen in plaats van troost, wel een scherpe schrobberinge nemende den generaal dit haar schrift op als ofse d'Comp. wilden wetten voorschrijven." 1

Onder het Engelsche bestuur werd de gedwongen ter beschikbaarstelling van vaartuigen afgeschaft, doch "door gebrek aan vaartuigen was de heer van Middelkoop reeds bij zijne aanvaarding des bestuurs verpligt geweest, den last tot het weder in werking brengen van genoemde verpligting te hernieuwen" - zeker eveumin een middel om de blijdschap bij den Inlander over onze terugkomst te vergrooten, al was ook aan dat bevel de onzin toegevoegd: "dat diegene, welke niet genegen was in deze een blijk van verkleefdheid aan de dienst en de belangen van Z. M. den Koning der Nederlanden te geven, zich van deze leverantie ten eenenmale als ontslagen konde rekenen"! Daarop werd door de hoofden eenparig verklaard: "dat hunne onderdanen bereid waren, niet alleen de verlangde orembaai's te leveren, maar buitendien nieuwe te bouwen", terwijl de negorij Hatoe, gelegen aan de baai van Amboina op Hitoe, die vroeger een kruis-orembaai met de negorij Noesanive moest leveren, nu een dergelijk vaartuig voor zichzelve uitrustte, omdat het volk van Hatoe zich niet met dat van Noesanive verstond ${ }^{2}$.

1 Rumphius, dl. I, bl. 134, 136, 147, 206.

2 Van Doren-M., bl. 37-38, waar voor Noesanive gedrukt staat eerst NoessaNivel en een paar regels verder Noessa-Niva. "Van dat oogenblik af" maar data laat de Schrijver steeds weg - dagteekende volgens Van Doren de weder-indienststelling van de kruis-orembaais, waarmede de kruidnagelen van ieder regentschap naar de hoofdplaat:s Ambon werden overgevoerd. - Het 
Veel hing nu af van het organiseerend beleid van den militairen commandant, overste Kraijenhoff. Wij weten, dat de Regeering hem slechts noode in deze verantwoordelijke positie had laten gaan ${ }^{1}$; C. C. G. G. zouden aanleiding vinden van te zeggen "het wel gevreesd te hebben"! Volgens zijn rapport aan legercommandant Anthing was hem op den $16^{\mathrm{n}}$ Mei door de Moluksche commissie medegedeeld 2: "dat er geloofwardige berigten bij hen waren ingekomen, dat er op het eiland Saparoea een opstand plaats had, hem kommandant derhalven uitnoodigende, om onverwijld, onder kommando van den aldaar met de lokale gesteldheid en den aard der ingezetenen bijzonder bekenden majoor der pionniers Beetjes, een detachement militairen van 150 of 200 man, zoo mogelijk Europeanen, gedeeltelijk uit het garnizoen van Amboina en gedeeltelijk van de in de baai liggende oorlogschepen, over de post Baguala door de binnen-baai, langs Haroekoe, met kleine orangbaais naar Saparoea af te zenden, ten einde aldaar den inlander vrees in te boezemen, en door goed beleid, het zij langs minnelijke wegen of anders door middel van wapenen, de rust te herstellen." Alzoo was het de Moluksche commissie, die majoor Beetjes van de genie, een man van weinig beteekenis ${ }^{3}$, vooropstelde als troepenaanvoerder; Kraijenhoff heeft hiertegen geen bezwaar gemaakt, den Legercommandant verder mededeelende:

"Dat daarop eene conferentie had plaats gehad tusschen de civiele en militaire autoriteiten der land- en zeemagt, waarin werd overeengekomen, dat men naar Saparoea zoude zenden een detachement van 200 hoofden, te zamengesteld uit 120 man van de linieschepen onder hunne officieren, dertig Europesche en vijftig inlandsche militairen;

samengaan van meer dan één negorij voor het onderhouden van een orembaai en daaruit ontstane quaestiën deden zich ook in den tijd der O.I. C. voor. Zoo in 1637: „Die van Oelat klaagden ook over die van Ouw, om datse hun te verre van Oelath met haer negorij begeven hadden en bij de redout waeren gaan wonen, waer op geresolveerd wierde dat Ouw niet te min bij provisie zou blijven bij Sorri Sorry en Tuaha met Oelath scheppen." „Die van Nalahia konden ook met den radja van Ameth niet wel accordeeren weshalven verzogten met die van Titaway voortaan te mogen scheppen, waar op voorn. radja van sijn Edelheijt gelast wierde beter tractement aan te doen". Rumphius, dl. I, bl. 144 en 145. - Hatoe en kaap (dus niet de negorij) Noesanive op onze kaart aangegeven.

1 Zie dl. I, bl. 403 en bl. 407-408.

2 Rap.-Anthing, bl. 310.

3 Zie dl. I, bl. 404 en 406. 
"Dat hij luitenant-kolonel, om te voldoen aan de begeerte van kommissarissen, den heer majoor Beetjes met het bevel over het voorschrevene detachement had belast en hem van de noodige instructie had voorzien, zoodat dientengevolge meergemelde majoor den $17^{\text {den }}$ Mei is vertrokken."

Toen dit rapport te Batavia kwam, heeft legercommandant Authing het beleid in deze van overste Kraijenhoff, blijkens zijn schrijven d.d. 20 Juni 1817 aau C. C. G. G., afgekeurd. In het rapport stond echter tevens bericht, dat de expeditie was vernietigd, zoodat niet valt uit te maken of eenerlei critiek zou zijn uitgeoefend, indien dit bericht nog niet was ontvangen. Ziehier Anthing's oordeel 1:

"Het schijnt mij toe, dat, bij de handeling daarvan, vele voor de dienst nadeelige fouten hebben plaats gehad. Vooreerst had de luitenant-kolonel Kraijenhoff niet moeten toegeven aan de begeerte van heeren commissarissen, om het bevel dezer gewigtige expeditie an den majoor Beetjes op te dragen; want hij had behooren te weten, dat die officier altoos bij het wapen der genie en nog wel hier te lande geëmploijeerd geweest is, en hij evenmiu kunde als ervarenis had. Men heeft zeker verondersteld, dat de zaak minder belangrijk was, dan die nader geworden is, en dat die meer door negotiatien dan militaire operatien beslist zoude zijn geworden. Maar een kommanderend officier mag zich nimmer door soortgelijke denkbeelden laten wegslepen; de majoor Beetjes schijnt gemanoeuvreerd te hebben, zoo als men verwachten moest dat hij manoeuvreren zoude, zonder plan van attaque en zonder op middelen van retraite bedacht te wezen.

"De wijze, waarop het detachement was zamengesteld, is niet miuder vicieus. Het had meer uit geoefende troepen moeten bestaan, en de zeelieden, zeker niet miuder dapper maar minder ervaren in de taktiek, had de luitenant-kolonel bij zich in het kasteel behooren te houden."

Kraijenhoff heeft zich ongetwijfeld aan critiek blootgesteld door de onhandige mededeeling Beetjes te hebben gezonden op begeerte van het burgerlijk gezag; dat althans kon hij nooit verantwoorden, ook al ware de expeditie gelukkig afgeloopen. $\mathrm{Nu}$ echter zooveel te minder. Wij kunnen ons anders zoo goed voorstellen, hoe dit hier is toegegaan. Engelhard, half verinlandscht, wiens stokpaard heette inlandsche ervaring - veertig jaren! bl. 486 - heeft

1 Rap.-Anthing, bl. 342. 
ongetwijfeld in Beetjes zijn man gezien. Toen van de vernietiging der expeditie te Batavia bericht werd ontvangen, was natuurlijk een ieder aanstonds vervuld van Beetjes' onkunde. Zoo schreef Mr. H. J. van de Graaff over den opstand te Saparoea d.d. 1 Juli 1817 naar Holland ${ }^{1}$ : "Mevrouw Van den Berg, die zwanger was, verwittigde daarvan haren oom, den heer Engelhard, die dadelijk 200 man van Ambon afzond, bestaande dit detachement uit 140 matrozen van de Evertsen en van de Nassau en uit 60 man troepen, zoo Europeanen als inlanders, gecommandeerd door den majoor Beetjes, een zoogenaamden liplap of half blanke, op Java geboren en opgevoed, naar de algemeene opinie een zeer onkundig officier."

Het is niet te weerspreken, dat de Majoor onkundig heeft gehandeld, maar overigens schijnt ook wel hier, de uitslag meer dan billijk is, de critiek tegen Kraijenhoff te beheerschen. Ik ga voorbij de veroordeeling in hare algemeenheid der keuze van den genieofficier als troepen-aanvoerder, al hebben wij toch ook wel genieofficieren gehad, die in deze qualiteit op expeditiën het er goed afbrachten; zij zullen wellicht een ervaring gehad hebben, die, naar Anthing's oordeel, Beetjes geheel miste ${ }^{2}$; maar men leest ook als een gebrek, dat de Majoor geen Europeaan was, geen Europeesche opvoeding had genoten. Een uitlating van gouverneurgeneraal Van der Capellen, 'n kleine tiental jaren later met het uitbreken van den opstand van Dipanegara, is in dit opzicht kenschetsend. Toen trok van Magelang naar Jogja een detachement, dat gedeeltelijk door de opstandelingen in de sawahs werd gejaagd en daar afgemaakt. De commandant ervan was een Europeaan pur sang, kapitein Kumsius, hetgeen Van der Capellen d.d. 28 Juli 1825 deed schrijven aan den naar Jogja op reis zijnden generaal De Kock ${ }^{3}$ : "Ik ben niet getroost over het verlies van onze 38 flankeurs, en ik geloof nog, dat kap ${ }^{t}$ Kumsius anders had moeteu handelen. Hoe kan men verkiezen zijne cameraden te verlaten, liever dan te samen zijn leven te verdedigen? Deze zaak zal door $\mathrm{U}$ wel tot klaarheid gebragt worden. Die ongelukkige sawa's zijn in tijd van regen altijd noodlottig voor de onzen, indieu zij de onvoorzigtigheid hebben zich daarin te begeven. lk herinner mij levendig het gebeurde in de residentie Cheribon in 1817 en 1818.

\footnotetext{
1 Brieven-V. d. Graaff, dl. II, bl. 15.

2 Cochius b.v., die zich te Bondjol onderscheidde, deed ervaring op als troepenaanvoerder in den Java-oorlog.

3 Rijksarchief.
} 
De baaren weten dit niet; daarom heb ik ondanks mijnen afkeer tegen liplappen, bij zulke gelegenheid liever officieren, die de geaardheid van het terrein kennen, dan de beste theoristen, die niet nagaan dat eens in de modderige sawa's gekomen, het den Inlanders niet veel moeite kost de European koelbloedig te komen vermoorden."

De samenstelling der expeditie wordt verschillend opgegeven; het aantal hoofden neem ik an groot $210^{1}$; ik vind echter ook vermeld $300^{2}$. Het is mogelijk, dat bij de 210 niet gerekend zijn de 55 man, die, gelijk wij zien zullen, door Beetjes zijn achtergelaten te Haroekoe onder den adelborst Musquetier ${ }^{3}$. Engelhard geeft op, behalve 4 adelborsten, aan Europeesche officieren, zoo van de land- als zeemacht, 8, benevens 146 Europeesche matrozen en soldaten met de onderofficieren. Vau den Evertsen en de Nassau werden geleverd detachementen, ieder groot 70 man. De luitenants Munter en De Jong, de adelborsten $2^{e}$ klasse Musquetier en F. X. R. 'T Hоогт - de laatste Ver Huell's berichtgever ${ }^{4}$, maar niet te verwarren met den schrijver van het hiervoren vermelde journaal H. P. N. 't Hooft ${ }^{5}$ - verder den stuurmansleerling HavERMAN, den chirurgijn $3^{\text {de }}$ klasse Ten Bergen, 38 matrozen en 26 mariniers, stond de Evertsen af. De luitenant Scheidius, de cadets $1^{\text {e }}$ klasse RiJK en V van de $N_{a ̊ s s a n u}{ }^{6}$. Daaaraan waren toegevoegd de koloniale troepen, sterk 50 man, onder den kapitein Stahlman en den $2^{\text {n }}$ luitenant VERBRUGGEN. - Verder vermeldt Engelhard 50 inlaudsche militairen onder een inlandschen luitenant: alzoo niet "ruim 100 Javanen", zooals ik elders vind medegedeeld ?. Onder de Amboneezen, die de

1 Dit getal wordt vermeld, niet alleen in den nader te noemen brief van Engelhard, die anders ook niet onvoorwaardelijk te vertrouwen is, maar evenzeer in het rap.-Anthing, bl. 541.

2 Bij Stuart, bl. 391.

${ }^{3}$ In het rap.-Anthing wordt namelijk medegedeeld eerst die achterlating te Haroekoe en dan over Saparoea, dat: „van de 210 hoofden, die derwaarts zijn vertrokken", slechts 65 terugkwamen.

4 Zie Ver Huell, dl. I, bl. 135.

5 Dl. I, bl. 342.

6 Hetgeen door de beide oorlogsschepen werd afgestaan, ontleende ik aan het journaal-B.

7 De afwijkende mededeelingen, zoowel ten deze als in andere opzichten bij Stuart, bl. 391 , ook al een slordig stuk. BeErJes wordt onjuist genoemd Beetjens en majoor der artillerie; kapitein Standaran heet er Straalman. De inlandsche luitenant heette Abdulmana; gedrukt is bij Stuart: Verbrugge, in het rapportAnthing: VAN der BrUgGen: in de handschriften vind ik VerbrugGen. 
expeditie zouden vergezellen, behoorde KrraULY, de regent van Siri Sori, naar wiens waarschuwingen niet gehoord was en die nu zijn dood te gemoet ging ' . Men had zich zoo sterk mogelijk uitgerust, ten einde reeds, heette het, met den eersten slag aan de rebellie een einde te kunnen maken. In den mallen verhaaltrant van Engelhard, deelt deze, blijkens bl. 613, als een bevelhebber van ervaring, mede: nog nooit zoo'n mooien troep gezien te hebben!

Het transport zou plaats vinden in z.g. orembaais, en wel, volgens Van Doren kruis-orembaais ${ }^{2}$, d.w.z., die "zouder roef dienen tot transport van nagelen, enz." 3 Het aantal dier vaartuigen zou zijn acht kleine en twee groote; een van de laatste was gewapend met twee draaibassen en had de leveusmiddelen aan boord.

Zooals men dit leest en men onwillekeurig ook uit verschenen publicatiën zou opmaken, krijgt men den indrak, dat de voor de expeditie bestemde vaartuigen te Amboina waren uitgerust, dat men er mede naar de Pas was gevaren, dat daar de vaartuigen over de Pas waren getrokken en de expeditie dit eindje had gemarcheerd, om aan de oostzijde gekomen er weder in te stappen en alzoo door te varen 4. Van dit alles schijnt echter niets juist; wat meer is, toen de expeditie Amboina verliet, bestond er niet eens nog zekerheid over de wijze, waarop men het eiland kon verlaten. Het is wel

1. Verg. bl. 566-567.

2 Van Doren-M., bl. 27.

s Van Doren-H. en S., dl. I, bl. 186. Ziehier, wat wij er echter lezen over de "twee soorten van vaartuigen, die zij orembaai's en kruis-orembaai's noemen". "De eerste, die tot sieraad dienen, hebben in het midden eene soort van overdekte roef, de andere zonder roef dienen tot transport van nagelen, enz. De laatste zijn van eene bijzondere lengte, met hoogopstekende voor- en achterstevens, die met fraai snijwerk versierd zijn. Eene soort van roef met een glad overdek, beslaat hare grootste ruimte." Dus de soort, waarvan de Schrijver eerst zegt, dat daarop geen roef is, heeft toch een roef, die liefst de grootste ruimte inneemt! Dat is geheel Van Doren. - In sommige stukken, als in de met taal en namen nogal eens zonderling omspringende scheepsjournalen, leest men orangbaik's, naïeve schrijfwijze, dacht ik van onze Marine. Maar bij dr. Martin las ik sinds, dat „orembaai ist eine Verstümmelung von orang baaik": Martin (1894), b]. 86, met af beelding. - Bij Van der Crab, bl. 5-6 leest men over de vaartuigen: „Deze orembaaijen zijn ongeveer 50 voeten lang en hoogstens 12 voeten breed, voor en achter even scherp gebouwd en laag bij het water. Op Banda worden enkele praauwen vervaardigd, maar het meerendeel wordt aangebragt van het eiland Seroea of van de Keijeilanden; vooral de Keijsche praauwen hebben bijzondere vermaardheid als deugdzaam van hout en bouw."

4 Zie o. a. Ver Huell, dl. I, bl. 133 en Van Doren-M., bl. 27. - Verg. dl. I, bl. 417-419. 
niet onmogelijk, dat de toedracht der zaak eenigszins auders is, maar het blijkt uit alles, dat eerst te Haroekoe de orembaais zijn bij elkander gekregen en uitgerust. Hoe uitputtend en demoraliseerend dit alles reeds bij den aanvang voor den troep moet geweest zijn, laat zich wel voorstellen.

Wij zullen nog herhaaldelijk van deze soort inlandsche vaartuigen lezen; zijn wij dan indachtig op het door eu door vermoeiende van zulk een tocht op een bewogen zee gedurende halve etmalen, niet ook beschuttende tegen zon, weer en wind, overslaande golven, geen gelegenheid gevende zich eenigssins uit te rekken of te liggen. Zelfs als men wegcijfert de vulling dezer vaartuigen met troepen, als men de passagiers-orembaais heeft, alzoo met "in het midden eeu soort van overdekte roef", wanueer men als gewoon reiziger een tocht er mede makt, laat de vaart slechts onaangename herinneringen na. "Deze praauwen zijn van 25 tot 50 voeten lang en 5 à 8 voeten breed", schrijft Van der Crab ${ }^{1}$; "zij hebben een of twee masten met een schoenerzeil en een kluiver; het midden gedeelte der praauw is overdekt met atap en bevat aan beide boorden eene bank van gaba gaba of planken, tot zit- en ligplaats; achter en voor, zitten de roeijers of schippers, zoo als ze hier genoemd wordeu; tusschen hen staat een met zand gevulde bak, die tot kombuis dient, alle hoeken en gaten zijn volgestopt met kleederkoffers, provisie, dranken, serviezen : kortom een geheele dispens; op de bezocht wordende eilanden is zoo weinig van die huishoudelijke zaken te bekomen, dat het medevoeren daarvan noodzakelijk is; zelfs de huizen daar, zijn niet bewoonbaar voor Europeanen; de praauw is woon- en slaapplaats gedurende den geheelen overtogt; zoo lang de weersgesteldheid het toelaat, wordt van de zeilen gebruik gemaakt, doch bij stilte of tegenwind moeten de roeijers aan het werk gesteld worden; die togten met praauwen loopen niet altijd langs fraaije stranden of over kleine afstanden, die op de kaart gezien niets beduiden, maar groote gevaren door holle zee en hevigen stroom, moeten daarmede dikwerf doorgestaan worden; zonder de grootste voorzigtigheid zou het aantal ongelukken, die thans zeldzaam zijn, veel grooter wezen. Die daarvan de ondervinding niet heeft, kan zich geen juist denkbeeld vormen vau de ellende op zulke reizen."

Hooren wij een veel later schrijven, dr. Martin ${ }^{2}$ : "Die Fahrten

1 Van der Crab, bl. 165. In den $4^{\mathrm{n}}$ regel dezer aanhaling staat schippers: ik denk dat bedoeld is scheppers.

2 Martin (1894), bl. 88-89. 
in einer Orembai sind in der Regel höchst unerquicklich. Bei Tag bietet die Kajüte mit ihren kleinen Fenstern keinen angenehmen Aufenthalt, so dass ich sie zu dieser Zeit auch fast nur bei eintretendem Regen aufzusuchen pflegte und mir in der Regel, so gut es eben gehen wollte, einen Platz am Bug des Schiffes, inmitteu der Ruderer, verschaffte; bei Nacht dagegen findet man auf den harten Holzbänken nur unvollkommene Ruhe, wenn es auch glücken mag, mit den übrigen Bewohnern des engen Raumes... unangenehme Berührungen zu meiden. Denn beständig lärmt einem über dem Kopfe die unerträgliche Musik, deren Eintönigkeit mich bisweilen in eine rasende Unruhe versetzte, und bei jedem Anziehen der Ruder wird man noch obendrein hin- und hergeschüttelt ... Mit solchem Fahrzeuge zu reisen erfordert Stumpfsinn oder Engelsgeduld; wer weder das eine noch das andere besitzt, der bleibe ihm möglichst ferne!"' ' Aan de ougeschiktheid dezer vaartuigen voor oorlogsdoeleinden werd ook, althans voor een deel, de ongelukkige afloop der expeditie geweten, de departementschef van Koloniën den Koning onder de oorzaken ervan noemende ${ }^{2}$ : "het gemis van kleine, ligt gewapende oorlogsvaartuigen, zou tot dekking der landing, het bijeenhouden der Indische vaartuigen als tot de retraite, niet minder dan de begane misslagen tot den ongelukkigen uitslag van dien hebben medegewerkt. Zoodanige vaartuigen zijn in de wateren der Molukkos en Celebes, tot in toom houding dezer immer woelzieke eilanders, ten allen tijde van het grootste nut geweest".

I Verg. dl. I, bl. 420.

2 Rapport d.d. 12 December 1817 N. 8988/413: Rijksarchief. 


\section{HOOFDSTUK V.}

\section{De expeditie van 17-20 Mei 1817 naar Saparoea.}

Organisatie der expeditie op de hoofdplaats Ambon, vertrek van Martin, een prins van Gilolo geïnterneerd op een oorlogssehip, Walraven naar Hila: 17 Mei. - Tocht te voet der troepen tot Soeli en Musquetier vooruit naar Haroekoe: 17 Mei. - Marsch naar Tial en overvaart naar Haroekoe: 18-19 Mei. - De expeditie over Pelaoe naar Saparoea: 19-20 Mei. - Landing der expeditie: 20 Mei. - Engelhard's beschrijving van het vertrek der expeditie en de vaart naar Saparoea. De poging der expeditie tot vermeestering van Duurstede. - De terugtocht: 20 Mei. - Van de prauwen, waarin de onzen zich trachtten te redden: 20-21 Mei. - Van de in leven geblevenen. - Het rapportPorto over den 20 Mei. - Engelhard's bericht over de nederlaag. Thomas Matulesi versterkt het eiland Saparoea. - Eed van geheimhouding door de rebellen. - De indruk te Ambon en Engelhard's uiting over de nederlaag.

Den $17^{\mathrm{n}}$ Mei verliet de expeditie de hoofdplaats Ambon ${ }^{1}$. Des morgens ten $5 \frac{1}{2}$ waren aldaar ontscheept de voor de expeditie bestemde, op de linieschepen aanwezige troepen, "allen wel gewapend, medenemende voor 4. dagen victualie", ten einde met het aan land zich bevindende deel der expeditie zich te begeven naar Bagoeala.

Denzelfden dag verliet resident Martin met de op Amboina aanwezige Britsche ambtenaren het eiland. In het journaal-'t Hooft ${ }^{2}$, waaraan dit ontleend is, leest men dan verder ad 17 Mei:

"In de $\mathrm{P}$ (lat) $\mathrm{V}$ (oet) aan boord gekregen den koning van het eiland Gilolo, genaamd Mahomed Oscaar, deszelfs vrouw Fatime en 4 bedienden, allen als staatsgevange aan boord. Men veronderstelde dat deze vorst oorzaak was van de onlusten op Saparoea, daar hij 7 jaren geleden door het Engels Gouvernement was gevangen genomen omdat den koning van het eiland Tidor ontevreden

1 In den straks weder te geven brief van Engelhard leest men, dat de expeditie van Ambon vertrok $16 \mathrm{Mei}$; hijzelf schreef echter in den brief

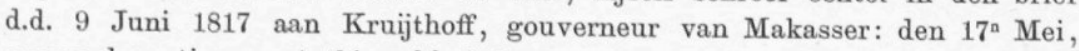
overeenkomstig rap.-Anthing, bl. 341.

2 Vermeld in dl. I, bl. 342. 
over hem was en aan wien hij cijnsbaar is; bij de verandering van het Gouvernement zouden de Giloleezen zijne onderdanen, de Alfoeren van Ceram te hụlp geroepen hebben om deze opstand te doen en hun te sterken.

"Tegen den avond zag men van hier in het gebergte van de overwal op Hila vuuren branden; er liepen gerugten, dat de Cerammers aldaar zouden zijn en daar de Hitouneezen (gedeelte van Amboyn) zelve een zeer onrustig volk is, zo werd den Heer Walraven met een detachement Javaansche soldaten derwaarts gezonden."

Nadat de expeditic te Ambon verzameld was, begaf zij zich over land "in eene felle hitte" naar den Pas '. Aanstonds zijn echter daar moeilijkheden ondervonden door gemis aan vaartuigen. Immers in het journaal van den te Amboina achtergebleven luitenant $\mathrm{t} / \mathrm{z} \mathrm{H}$. P. N. 't Hooft staat op 18 Mei : "Wordeu geïnformeerd door een brief welke de majoor Beetjes had gezonden per expresse, dat de expeditie aan de pas Baguala geene vaartuigen had gevonden, dat hij van daar de adelborst $1^{\mathrm{e}}$ klasse Musquetier met een klein detachement naar Haroeka had gezonden, en dat hij vervolgens met de troepen naar de N.-O.punt van Amboyna marcheerde om van daar verder te gaan met vaartuigen, welke hij hoopte te vinden." Op de beide volgende dagen ontving men te Ambon geen nader officieel bericht. Wel liepen er den $19^{\mathrm{n}}$ geruchten, dat de expeditie te Haroekoe was aangekomen; dien dag werden er van Ambon nog 15 matrozen naar den Pas gezonden "om post te houden" 2 .

"De hitte vau deu dag en het laat aankomen van eenige vaartuigeu", leest men in het onduidelijke verhaal van Stuart over den Pas 3, "veroorzaakten, dat men eerst des avouds van gemelde landingsplaats voortrukte." Men marcheerde tot Soeli, aan de noordkust van de baai gelegeu, "alwaar men zeer laat ankwam, eu geene verversching kon bekomen, hoezeer zulks behoevende". Ook te Soeli blijkt niet geëmbarkeerd te zijn. "Op den $18^{\text {den }}$ vervolgde men met het aanbreken van den dag den krijgstogt over de gebergten, bij wier beklimming sommigen door het vallen ligt gekwetst, anderen door den dorst flaauw werdeu. Aan eene negerij gekomen zijule nabij het strand" - Tial? — "werden de vaartuigen

1 De aanhaling van Stuart, bl. 391. Verg. hiervóór bl. 605-606.

2 Journaal-'t Hooft. Verg. dl. I, bl. 342.

s Stuart, bl. 391. 
aldaar in orde gebragt, en de troepen overgevoerd tot Haroeka" ${ }^{1}$. De expeditie ging alzoo niet rechtstreeks naar Saparoea; zij verbleef te Haroekoe en wel "om toebereidselen te maken tot de landing in de baai van Saparoea" 2. Dat eerst hier, gelijk ik op bl. 605-606 aangaf, de tien vaartuigen, die de expeditie verder zouden brengen, werden gevonden en uitgerust, wordt nog bevestigd door een mededeeling ad 21 Mei in 't Hooft's journaal, waarin staat aangeteekend, dat van de verslagen expeditie enkelen te Ambon waren teruggekomen en verhaald hadden, dat men was gegaan "van Haroeko gezamentlijk naar Saparoea in orangbaais, waarbij een kori-kori was, waarin eenige victualij en amenutie waren". Het hiervoren vermeld vooruitzenden van Musquetier zal wel ten doel gehad hebben de organisatie voor te bereiden. Mar welk een gaan op goed geluk!!

De expeditie is te Haroekoe aangekomen zeer uitgeput den $19^{\mathrm{n}}$, naar ik denk ${ }^{3}$. Toen eerst veruam men, "dat de inwoners van Haroekoe an den kant van Saparoea mede in opstand waren", waarom Beetjes het noodig achtte "aldaar", bedoeld wordt echter te Haroekoe, "een detachement van 55 man, onder bevel van den $2^{\text {den }}$ luitenant Musquetier te moeten laten" 4.

I Zie over dezen weg, dl. I, bl. 419. In het journaal van 't Hooft, staat, dat op dien tocht van Ambon naar Haroekoe "bij de hoek van Cajelolo een praauw met 5 Cerammers (werd) genomen, welke alle gefusilleerd werden". Hij had het gehoord van de teruggekeerden der expeditie Beetjes op 21 Mei. Ik vermoed echter, dat dit een verplaatsing is van hetgeen met Cerammers te Pelaoe gebeurde, toen de expeditie van Harockoe vertrok naar Saparoea, gelijk wij nader zullen lezen op bl. 611 .

2 Ver Huell, dl. I, bl. 133.

${ }^{3}$ In een brief van Engelhard zullen wij lezen den $19^{\text {n }}$ (bl. 613). In het rapportAnthing, bl. 341, staat, dat men toen reeds naar Saparoea op weg was. Ver Huell, dl. I, bl. 133, deelt mede, dat men Haroekoe bereikte "na eenen moeijelijken togt van twee dagen", hetgeen dan ook wordt de $19^{\circ}$.

4 Kraijenhoff had den $20^{\text {n }}$ Mei brieven van Beetjes ontvangen, waarin dit gemeld stond; zie Rap.-Anthing, bl. 340-341. Musquetier was echter geen ${ }_{n} 2^{\text {de }}$ luitenant", maar een aan de expeditie toegevoegde adelborst van den Evertsen: Ver Huell, dl. I, bl. 133-134; daar staat, in plaats van 55, dat 20 man werden achter gelaten. In het rapport-Porto volgt op de aanhaling, die wij op bl. 592-593 lazen, dit:

${ }_{n}$ Den $18^{\mathrm{n}}$ Mei ging Thomas Matulesi naar Hoelalioe om de radja's en patihs van Boeang bessy (Haroekoe, verg. bl. 466, noot 5 en bl. 583 , noot 5) te bevelen het fort te Haroekoe aan te vallen. Den $19^{\text {n }}$ Mei des morgens omstreeks 6 uur kwamen de menschen van Hoelalioe aan Th. Matulesi berichten, dat de Compagnie van Ambon reeds te Haroekoe was aangekomen en omstreeks 8 uur verzamelden zich burgers van Saparoea om de Compagnie te Haria af te wachten." 
Dat detachement heeft het dus wel getroffen, dat het niet mede ten verderve werd gevoerd. De expeditie begaf zich gedeeltelijk in de vaartuigen, gedeeltelijk over land uaar Pelaoe ', "de randsels zoowel als de chacots en overtollige bagagie" te Haroekoe achterlatende. "Zij, die te scheep gegaan waren, landden aan verscheiden negerijen, zagen eenige vaartuigen uit den Ceramschen wal komen, vervelgden dezelven, schotẹn er op, en makten zes man gevangeu, waarvan er twee stierven, en twee zwaar gekwetst waren. $\mathrm{Na}$ gehouden krijgsraad werden dezen en de twee overigen aan het straud gefusilleerd." Dit geschiedde ter negorij Pelaoe, "omdat men hen niet naar Amboina konde zenden" 2.

Te Pelaoe scheepte zich de geheele expeditie des avouds van den $19^{\mathrm{n}}$ weder in. Den nacht van den $19^{\mathrm{n}}$ op den $20^{\mathrm{n}}$ voer men in stilte onder den wal langs de noordkust van het eilaud Haroekoe, om vervolgens "tusschen de eilanden Haroeka en Honimoa door" 3 , te nadereu "de westkust van Saparoea... en langs die kust naar Saparoea" op te varen ${ }^{4}$. Vergeleken met een vaart langs de zuidkust van Haroekoe, een groote omweg, maar in dezen tijd van het jaar, was het daar onstuimig, aan de noordkust daarentegen betrekkelijk stil ${ }^{5}$.

Den $20^{\text {n }}$ was "de geheele expeditie" "des morgens ten zeven ure in den mond van de baai" van Saparoea ${ }^{6}$. De vloot van 10 kora-kora's ? gekomen zijude "tot op de hoogte van Paperoe" ${ }^{8}$,

1 Pilaam, staat in het Rap.-Anthing, bl. 341. - De in den tekst volgende aanhalingen van Stuart, bl. 391-392. - Verg. over Pelaoe dl. I, bl. 467. Op onze kaart geschreven Pelauw.

2 Rap.-Anthing, bl. 341, waar gesproken wordt van een ontmoeting „met vijf Ceramsche praauwen, waarvan er twee prijs zijn gemaakt, waarin twee man gesneuveld en een gekwetst waren, en voorts nog drie Cerammers, die gevangen zijn genomen, en kort daarna zijn gefusilleerd".

s Ver Huell, dl. I, bl. 134.

4 Rap.-Anthing, bl. 341.

5 Van Hoëvell, bl. 14-15. Verg. hiervóór bl. 595.

${ }^{6}$ De aanhaling van Ver Huell, dl. I, bl. 134, waar echter geen datum vermeld staat. Op bl. 133 staat, dat men "twee dagen" te Haroekoe bleef en "des nachts den $22^{\text {ston }}$ Mei" zich inscheepte, hetgeen door Van Doren-M., bl. 28, wordt nageschreven. Engelhard's mededeeling, in den op bl. 613 te melden brief, dat "de oversteek" naar Saparoen op den $20^{\text {n }}$ plaats vond, behoort als juist te worden aangenomen. Men leest dien datum ook in het journaal van 't Hooft, die het opteekende uit den mond der van de expeditie teruggekomenen.

7 In het rap.-Anthing, bl. 341, leest men, dat er waren „elf praauwen".

8 Van Doren-M., bl. 28. - Verg. hiervóór dl. I, bl. 471. 
doet zij, wat Engelhard noemt, een "oversteek"; want fort Duurstede en negorij Saparoea liggen aan de overzijde. Beetjes liet echter daarop niet rechtstreeks afgaan, maar de vloot zeilde eenigszins oostwaarts op naar Wai Hanaia, "een kwartier uur beoosten het fort Duurstede" ". Waarom dit geschiedde, is niet bekend, misschien in de veronderstelling, dat de rebellen zich vooral bij fort Duurstede hadden verzameld en men eerst moest trachten veilig te landen. De branding bleek er echter zóó hevig, dat de ontscheping niet raadzaam werd geacht, "waarom hij langs het fort heen naar Way Sisi, eene kleine rivier tusschen Tiow en Paperoe, liet scheppen, op welk punt de vaartuigen gezamenlijk aankwamen, en ongeveer ten tien ure des voormiddags de troepen aan wal stapten" 2.

Engelhard heeft een beschrijving van het vertrek der expeditie en van de vaart naar Saparoea gegeven o. a. in een brief d.d. 3 Juni 1817 aan den gewezen landvoogd Siberg, zijn zwager. $\mathrm{Na}$ medegedeeld te hebben hoe de berichten over het uitbreken van den opstand werden ontvangen van scriba Ornek, die er tevens posthouder heet, en van mevrouw Van den Berg, "onze dierbare nigt", vervolgt hij aldus:

$\mathrm{Na}$ ontvangst van deze fachieuse gebeurtenissen, werd geen ogenblik verzuimd, om een detachement uit de zeevarenden van Z. M. scheepen Nassau en Evertsen, en militairen uit het garnizoen, bij een te brengen en naar Sapparoua af te zenden; dan geen geschikt vaartuig aan handen hebbende, dit commando over zee naar Sapparoea te transporteren, moest de expeditie over de Pas met roeij vaartuigen ${ }^{3}$.

Den $16^{\mathrm{n}}$ des morgens vertrok dat detachement, bestaande in

8 Europeesche officieren zo van de schepen als het garnizoen

4 > adelborsten

I46 „ zeevarenden en militairen zo onderofficieren als gemeenen

I Inlandsche luitenant en

50 onderofficieren en gemeenen

aangevoerd door den Majoor van de genie Beetjes, expresselijk

1 Van Doren-M., bl. 28. - Wai $=$ stroom. De aan de stroomen gelegen plaatsen dragen dikwijls denzelfden naam: Olivier, dl. I, bl. 293, noot 1. Op de Siahaijakaart ingeteekend, niet op de onze. Men schijnt dus ,tot op de hoogte van Paperoe" teruggekeerd te zijn en daar geland in weerwil van de branding.

2 Van Doren-M. , bl. 28-29. Er staat daar echter niet Way Sisi, gelijk ik deed drukken en op onze kaart aangeven, maar "Way Asil", een naam, dien ik verkeerd medegedeeld acht.

s Deze voorstelling van over de Pas is niet juist; 't is alsof men met de onbeholpen wijze der uitrusting niet voor den dag wil komen. 
tot het doen van deze expeditie verkozen zijnde, als met het locale van Sapparoua en den aart van den Inlander bekend en van wien wel de beste uitslag konde verhopen.

Ik moet bekennen, nimmer schoner corps gezien te hebben, als dit detachement, en de ufficiers, onderofficiers en gemenen alle vol moet en bezield met een ijverzugt om de bezettelingen op Sapparoua hulp toe te brengen.

De Commandant Militair wilde niets risqueren, en daarom met Commissarissen overeengekomen tot het afzenden van zo een sterk detachement om dadelijk de muitelingen te imposeren en des te gemakkelijker te brengen tot onderwerping en ingevalle de Resident en bezettelingen in handen der muitelingen mogten gevallen zijn, te eerder op vrije voeten te doen stellen. Zo als ook distinctivelijk den gemelde commandant Beetjes bij zijne Instructie van den Millitairen commandant Kraijenhoff was voorgeschreven.

Wegens het ongunstig jaargetij en de aanhoudende sware regens als de ongeschiktheid der vaartuigen, veroorzaakte het detachement met onbeschrijffelijk veel tegenspoeden te kampen had. Door moed en standvastigheid kwamen dezelve nogtans alles te boven, het geen evenwel aanmerkelijk vertraagde hunnen overtogt. Den $19^{\text {n }}$ kwam hetzelve te Haroekoe en deed den $20^{\text {n }}$ de oversteek naar Saparoua, de plaats van derzelve destinatie, maar helaas ook de plaats van de noodlottige omkoming van dit detachement, van zo veele brave en dappere mannen waaruit hetzelve bestond en waarvan maar een gering gedeelte hun leven hebben afgebragt. Dit drukke ik niet uit, zonder het storten van gewillige traanen.

De plaats der ontscheping was aller ongelukkigst gekozen, namelijk op een moerassigen grond, in de binnenbaai '. Beetjes zou er, volgens Van Doren, door verlokt zijn, omdat zich daar geen strijdbareu vertoonden, immers enkel "vrouwen, kinderen eu wecrlooze manuen"; maar volgens denzelfden schrijver waren dezeu geplaatst "op last van Matulesia, aan het strand beoosteu het fort", terwijl men ten zuidwesten ervan landde. De vijand "volgens accurate opgaven" "op 800-1000 weerbare manuen gerekend", waaronder "vele Cerammers", "benevens een aantal Alfoeren" hield zich bij Tiow op, ten einde "de onzen in den rug te vallen", een "krijgslist", die volkomen gelukte. In hoever dit alles zich inderdaad zóó heeft toegedragen, kan niet nader geverifieerd

1 "Dort findet man, umgeben von sehr unbedeutenden Bodenwellen, einen Morast, welcher zur Regenzeit ganz von Wasser bedeckt wird..." Martin (1894), bl. 28. 
worden '. Wel moet aangenomen worden, dat bij nadering der vloot, de onzen zagen "een groote menigte volk.... marcheren, 't welk van achter de klippen van tijd tot tijd op de ouzen schoot, zonder echter iemand te bereiken"; "dat tegen elf uren voor den middag de praauwen in de baai van Saparoea aan de linkerzijde van het fort zijn gekomen, alwaar de troepen ziju ontscheept"; eindelijk, "dat bij het landen door de rebellen sterk wierd gevuurd" 2 . De ontscheping wordt ons ald us verhaald ${ }^{3}$ :

"Op een bepaald sein vergaderde zich de geheele flotille, en de Kommandant beval, om zich, bij het inroeijen van de baai, in eene linie van bataille in het front te formeren, waarvan hij zelf het centrum zoude uitmaken, en, dat de twee groote vaartuigen achter de linie zouden opsluiten, en in die orde allen te gelijk op het strand loopen, als wanneer, op het lossen van een pistoolschot, de officieren de eerste helft der manschappen zouden doen landen, onder bedekking der andere helft, welke, zoodra de eerste helft post had gevat, door de rest der manschappen gevolgd zoude worden.

"De Indianen waren echter op hunne hoede; want terwijl de linie zich, al binnen stevenende, formeerde, werd zij vau de kust door een hevig musketvuur begroet. De onzen deden echter geen enkel schot terug ${ }^{4}$.

"De Kommandant wendde den steven naar eene bog't der 'baai, links van het kasteel Duurstede, en de vaartuigen liepen alle gelijktijdig op het strand. Het sein tot ontscheping werd gegeven, en onmiddellijk uitgevoerd."

Hoe had die uitvoering plaats? "Ondersteund door eenige schoten uit de draaibassen van de kruis-orembaai's, in orde", is gepubliceerd ${ }^{5}$; maar Engelhard schreef in zịn Bataviaasch verslag: "Bij de landing der troepen had veel overhasting plaats gevonden, waardoor vele in zee moesten springen om de wal te bereiken, zoodat patrouen, ransels en patroontasseu nat zijn geworden. Dit

1 Van Doren-M., bl. 29. De Schrijver heeft in 1836 Saparoea bezoclit „en het was bij die gelegenheid, dat ik door den Radja Mriranos Jacob Trtalay van Saparoea, welke mij vergezelde, omtrent het gebeurde van $18 \mathrm{I} 7$ werd ingelicht": bl. 35 .

2 Rap.-Anthing, bl. 341.

s Ver Huell, dl. I, bl. 134-135. Zijn zegsman is adelborst 't Hooft, die de expeditie medemaakte: bl. 604.

4 Dit ook bij Van Doren-M., bl. 29.

- Van Doren-M., bl. 29. - Op bl. 605 hiervóór deelde ik mede, dat slechts op één der groote orembaais draaibassen waren. 
werd ontdekt, nadat de eerste geweerschoten waren gewisseld, welk toeval den, Commandant deed besluiten zich weder in te schepen om daariu te voorzien."

Dat het nat worden van het kruit en alzoo het niet afgaan der schoteu aanstonds eenige ourust veroorzaakte, is wel mogelijk; maar dat Beetjes den terugtocht uit dieu hoofde gelastte, viudt men overigens nergens gemeld.

De rebellen, aangevoerd door Matulesi en Rhébok ${ }^{1}$, lagen verscholen in het dichte kreupelbosch, dat zich langs het strand tot aan zee uitstrekte; zij ontvingen de onzen met een zeer levendig en wel gericht vuur. De luitenaut $t / z 2^{\mathrm{e}}$ klasse Munter van den Evertsen stond in zijn orembaai het bevel tot landen gevende, toen hij al aanstonds doodelijk werd getroffen ${ }^{2}$.

Hoe het verder is toegegaan, blijkt niet helder door gemis aan een schetsteekening en nauwgézette beschrijving ${ }^{3}$. De aan land gekomen troepen schijuen gesteld te zijn ouder den kapitein Staalman van, de infanterie ${ }^{4}$; hij, alzoo niet de majoor-commandant, "verdeelde de ontscheepte legermagt in drie divisiën, welke ieder een anderen weg zouden inslaan naar het kasteel Duurstede" 5, "waarvan de muitelingen de Eugelsche vlag lieteu waaijen" ${ }^{6}$. Een dier divisiën stond onder den luitenant der infanterie VerbrugGen ${ }^{7}$, terwijl "de majoor Beetjes, de kapitein Staalman en de luitenant ter zee Scheidius te zamen met hunue troepen zijn gebleven" ${ }^{8}$. Aan Verbruggen werd door Staalman gelast "om met de flankeurs langs

I Van Doren-M., bl. 32.

2 Naar aanleiding van hetgeen de te Ambon teruggekeerden aan luitenant 't Hooft vertelden, teekende deze in zijn journaal op: "Men was den 20ste in de baaij van Saparoua geland, aan de westkant van het Fort voor een klapperboomenbos. De Indianen welke zich in menigte agter de boomen en in dezelve verscholen hadden, vuurden wakker op ons volk, dat lande, waardoor den luit. Munter aan de zijde van den jonker 't Hooft in de praauw sneuvelde door een kogel in den linkerborst."

3 "Geen behoorlijk rapport van het voorgevallene" kon verkregen worden; în de plaats trad „een zeer konfus relaas, gegeven door den $2^{\text {den }}$ luitenant van der Bruggen en den sergeant Louwkamp". Rap.-Anthing, bl. 341.

4 Vermeld op bl. 604 .

- Ver Huell, dl. I, bl. 135.

- Engelhard in zijn Bataviaasch verslag.

7 Deze luitenant behoorde tot de weinigen der geredden en heeft het verslag over den ongelukkigen dag aan generaal Anthing opgemaakt. Over zijn naam, zie bl. 604 , noot 7 .

8 Rap.-Anthing, bl. 341. Scheidius is niet gebleven: hij werd zwaar gekwetst naar Ambon teruggebracht, gelijk we zullen lezen op bl. 621-622. 
den weg, die naar het fort geleidt, in het bosch te dringen, om het te zuiveren" '; aan den hem toegevoegdeu adelborst F. X. R. 'т Hooft "werd de Nederlandsche vlag toebetrouwd, welke bestemd was op de wallen van het kasteel Duurstede geplant te worden, wanneer deze sterkte in onze magt zoude ziju" 2.

De divisie ging voorwaarts onder een hevig geweervuur "tot aan zekere plaats, Hatoemarhoe geuaamd, eeneu afstand van 150-200 passen van de brug van Way Sioel gelegen" ${ }^{3}$; in ieder geval ging het niet recht toe, recht aan naar het fort. Opgehelderd werd nooit, wat Beetjes er toe heeft geleid om aldus te ageeren. "Het blijft onverklaarbaar", schrijft Ver Huell *, die anders wel gelegenheid had om inlichtingen bij deelhebbers aan de expeditie in te winnen en boveudieu later om op de plaats zelve zich vau de toestanden te overtuigen, " waarom de Kommandant Majoor Beetjes niet dadelijk op het kasteel Duurstede is losgegaan, waarin hij zich had staande kunnen houden tegen eene geduchte magt, in plats van eeue landingsplaats te kiezen, besloten door digt geboomte, en waar geen strand genoeg was, om zich behoorlijk in slagorde te stellen. De listige Indianen, genesteld in het dikke struikgewas, velden het eerste de officieren, als bewust zijnde, dat, wauneer de opperhoofden ontbraken, de wanorde spoedig volgen moest." Onder deze omstandigheden kreeg Verbruggen het toenemend zwaar te verantwoorden. Tegen den opdringenden vijand liep hij tot twee malen toe storm, doch werd telkens met verlies teruggeslagen. Ten derden male wilde hij zich doorslaan, toen hem het sein vau terugtrekken ter oore kwam. Hieraan gevolg gevende, deed zich tot drie malen toe een hioé! 'u hoerah! van de zijde der rebelleu hooren; zij, die voor ons vuur waren teruggedeinsd, kwamen met nieuwen moed opzetten ${ }^{5}$. Volgeus het rapport van Anthing ${ }^{6}$, "hoorde" Verbruggen

1 Als in de vorige noot.

2 Ver Huell, dl. 1, bl. 135; 't Hooft behoorde ook tot de geredden.

s Van Doren-M., bl. 30. De namen kan ik niet thuis brengen. Wordt misschien bedoeld Wai Sisi: hiervóór bl. 612 , noot 2 ?

4 Ver Huell, dl. I, bl. 145-146.

5 Van Doren-M., bl. 30. - Bij Ver Huell, dl. I, bl. 136, leest men over de divisie-Verbruggen: „Al strijdende bereikten zij eene groote loods, waaronder een vaartuig stond. Het vuur des vijands werd hier zoo hevig, dat de Luitenant Verbrugge het besluit nam, op den vijand met geveld geweer in te stormen. Tot tweemalen toe door eene groote overmagt teruggeslagen, wilde deze brave officier, in weerwil van een reeds zwaar geleden verlies aan manschappen, eenen derden aanval beproeven, toen het sein van retraite gehoord werd, dat in de meest mogelijke orde uitgevoerd werd."

6 Rap.-Anthing, bl. 341. 
de troepen der andere divisiën "aanmarcheren, waarop" - heel duidelijk is het verband niet - "waarop door den kapitein Staalman bevolen werd, om met het detachement zich weder te vereenigen".

Op den terugtocht werd de inlandsche luitenant Abdulmana met zijn detachement Javanen aan de linkerzijde van het fort aangevallen; hij verdedigde zich "sterk"; te gelijkertijd werd met een groote macht ook "een aanval op den majoor Beetjes" gedaan; de onzen verdedigden zich "manmoedig", doch moesten voor de overmacht wijken, zoodat "de linker vleugel in het water werd gedreven".

Onder de bedrijven door was de luitenant Scheidius, "door een musketkogel in den linkerschouder zwaar gekwetst" 1, op raad van luitenant De Jongh naar een der vaartuigen gebracht om door den chirurgijn behandeld te ${ }^{*}$ worden ${ }^{2}$. De luitenant $\mathrm{V}_{\mathrm{AN}}$ LIDTH DE JEUDE, met de Inlanders de reserve uitmakende, ontscheept zijnde, lieten de rebelleu het geheele korps zonder veel tegenstand voortrukken tot een plaats, die vermeld wordt als te heeten Kaytees! ${ }^{3}$, alwaar men echter gedwongen werd halt te houden; want de rebellen, achter de boomen vurende, doodden velen der onzen, zoodat eindelijk majoor Beetjes, "oordeelende, dat er niets uitgerigt kon worden tegen eenen verborgen vijand, die naar alle kanten verderf verspreidde, met overhaasting naar het strand terug week". $\mathrm{Zij}$, die zich met den gewonden luitenant Scheidius bij de booten bevonden, "zagen slechts een uur of vijf kwartiers na het ontschepen, het grootste gedeelte der troepen naar strand terugkeeren en met overhaasting te water gaan, om de vaartuigen te bereiken". Majoor Beetjes, "tot over den middel in het water, wegens den hoog geloopen vloed, ontiving een schot in het achterhoofd; de adelborst Anemaet sloeg zijue handen naar eene prauw, doch dezelve reeds voortroeijende, miste hij, en verdween. De praauwen werdeu nu met kracht van riemen ter baai uitgeroeid."

"A general, if not his army, must always take into account his position in the event of defeat as well as in that of victory (unless he is staking all on a single throw, and wishes for no choice save that between victory and annihilation)" 4 . Men leest inderdaad van bevelhebbers, die de schepen, waarmede hun troepen in

\footnotetext{
1 Journaal 't Hooft.

2 Stuart, bl. 393.

s Stuart, bl. 393, aan wien dit gedeelte van het verhaal door mij ontleend is.

4 Bernard W. Henderson: "Civil war and Rebellion" (1908), bl. 49.
} 
vijandelijk land ziju gebracht, met opzet verwijderden of in brand staken, ten einde het duidelijk te maken, dat men slechts zal te kiezen hebben tusschen overwimnen of sterven; ook leest men steeds, dat dit middel geleid heeft tot overwinning. Of de critiek, in geval van nederlaag, wel dergelijke bravoure-dadeu onaangetast zou lateu, weet ik nog niet zoo zeker, maar wel verdient het hoogelijk afkeuring, dat men de vaartuigen, die moeten blijven liggen, in afwachting van hetgeen gebeuren zal, zóó slecht verzorgt, dat ze afdrijven of wel ze achterlaat met niet voldoende te vertrouwen manschappen. Er zijn omtrent het gebeurde met de orembaais van Beetjes twee lezingen. De eene is deze 1: "De vaartuigen niet bewaakt zijude, waren door den aflaudigen wind van het strand gedreven, zoodat alle aftogt afgesueden was." De andere, die mij wel zoo aanuemelijk voorkomt - beide omstandighedeu kunnen bovendien samengewerkt hebben - luidt, dat toen een ieder ziju heil iu de vlucht zocht, dit slechts aan weinigen gelukt is, "dewijl de praauwen meerendeels de vlugt namen toen men uit deze vaartuigeu de konfusie aan 't strand ontwaarde" 2. De divisie-Verbruggen was teruggekeerd " $"$ in de meest mogelijke orde ${ }^{3}$; de inschepingsplaats nadereude, zag ze de onzen worstelen "tegeu een' overmagtigen vijaud, die alles ter nedervelde". "Het strand was met lijkeu en stervenden bezaaid, velen stonden tot aan den hals in zee, en werden ook daar door de verwoede Indianen gevolgd..." Toen de weinige geredden te Ambon den $21^{\mathrm{n}}$ Mei terugkwamen en hun wedervaren vertelden, teekende luitenant $\mathrm{t} / \mathrm{z}$ 't Hooft het volgende o. a. nog hiervan op in zijn journaal: "Terwijl men duidelijk zag, dat de magt des vijands te groot en wel versterkt was, waardoor de onze in wauorden geraakte, was den majoor Beetjes genoodzaakt te retireren, welke geensints geregeld konde geschiedde en een ieder die zich konde redden, naar de praauwen ijlde, dog daar er vaartuigen waren losgeraakt en met het vaarwater weggedreven, zo waren veelen genoodzaakt om zich al zwemmende te redden. De vijand agtervolgde die, en onthoofde de vlugtelingeu, zommigen al zwemmende met humne kleewangs, zoodat van de geheele expeditie zich redden konde den adelborst $2^{\text {de }}$ klasse 't Hooft, welke zijn praauw al zwemmende bereikte en

1 Ver Huell, dl. I, bl. 136.

2 Rap.-Anthing, bl. 342.

s Ver Huell, dl. I, bl. 136, van waar ook de volgende aanhalingen. 
de 8 man hiervooren gemeld. Men zag een zwemmende mariuier door deu vijaud in enen slag het hoofd afhakken. De majoor Beetjes onderging het zelfde, de kap $^{t}$ Staalman, welke de sabel aan den vijand presenteerde om zich over te geven, den luitenant ter zee De Jong, van Lidt en Rijk alsmede de andere kadets enz. ondergingen het zelfde. De luit. Verbrugge met nog een zeekadet en eenige manschappen 'redden zich. De luit. Scheidius, die na het ontvangen van zijne blessure in de praauw was gebragt, werd gered, alsmede de chirurgijn $3^{\text {de }}$ klasse Ten Bergen, welke door een slag met de kolf van het geweer vau den vijand gekwetst was. Van de geheele expeditie, die uit circa 300 man bestond, waaren bijua 30 man gered, waarvan een gedeelte op Haroekoe gebleven zijn."

Slechts van vier der te Saparoea gelegen hebbende vaartuigen vernemen wij eenige bijzonderheden, die wij moeten aaunemen, zooals ze geboekstaafd zijn.

Omirent een er van lezen wij ${ }^{1}$ : "Bij het uitroeijen van de baai was een vaartuig omgeslagen met 40 à 50 man, die allen verdronken."

De tweede en de éénige, die Ambon bereikte, was een der groote kruisprauwen, een zeilvaartuig, beladen met kruit, voedingsmiddelen en water, die schijnt gestaan te hebben ouder de leiding vau den orang-kaja van Batoe merah, een negorij in de nabijheid van de hooflplaats Ambon ${ }^{\overline{2}}$. Vermoedelijk dat, toen de landing plaats vond, deze op een afstand achterbleef en dat het negorij-hoofd, de vlucht der ouzen ziende, dadelijk onder zeil ging; er wordt althans geen melding gemakkt van gevluchten, die dadelijk in de boot redding vonden. Dat men over de houding van dezen bas niet tevreden is geweest, blijkt uit de volgende mededeeling ${ }^{3}:$ "De orangkaya van de negorij Batoe-mejrah, een vroom Mohammedaan, hoewel in zijne betrekking zeer actief en niet onknap, was ook voor suspect te houden, niet alleen, omdat het scheen, dat hij in het vertrouwen van de muiters deelde, maar buitendien, omdat hij aan het mislukken der expeditie van den Majoor BEETJEs, waarover wij nader zullen uitweiden, de hand moet geleend hebben. Volgens officiële bescheiden moet hij met zijne orembaai en de bemanning, in stede van aan de actie deel te nemen, in zee gestoken en op de vlugt gegaan zijn; terwijl van het door hem outvangen getal geweren slechts tien

1 Stuart, bl. 394.

2 Verg. dl. I, bl. 425. Bij Stuart, bl. 394, leest men „van den Ourang-baja te Batomara"! - Zie over het vaartuig ook hiervóór bl. 610 .

3 Van Doren-M., bl. 16. 
zonder eenig kruid zijn teruggegeven. Ook was door den Magistraat van Amboina bij een zijner negorij-voiken een aan boord van de Nassau vermist Fransch pistool gevouden; door welk een en ander het wantrouwen, dat men in dat hoofd stelde, niet ongegrond was."

In het derde vaartuig wisten te ontkomen de luitenant $\mathrm{t} / \mathrm{z} .2^{\mathrm{e}}$ klasse G. Nilant Scheidius, zwaar gewond; de chirurgijn der $3^{\text {e }}$ klasse $\mathrm{V}_{\text {AN }}$ OPDORP; de stuurmansleerling HAVERMAN : "in 't geheel twintig koppen" '. De orembaai "kreeg nog 10 Pelauwer roeijers over, om spoedig voort te komen", lezen wij ${ }^{2}$; maar het blijkt niet van waar ze over kwamen: waren het wellicht te Pelaoe gepresten - bl. $611-$ die nu ook vluchtend hun heil in een andere schuit zochten? In ieder geval bleken zij niet te vertrouwen; want het verhaal deelt verder mede, dat zij "onder den wal na het eiland Haroeka gekomen, het er op toelegden om aldaar aan wal te gaan". De oppasser van Beetjes, mede in deze prauw zittende, waarschuwde Haverman, "die terstond de geweren liet afdroogen, en op nieuw laden of van pankruid voorzien, om des noods geweld te gebruiken". Intusschen wist men de roeiers "door medelijden met den gekwetsten te bewegen, om van wal te komen", waarmede, denk ik, bedoeld zal zijn, van wal te houden.

De geredden in deze orembaai hadden intusschen outwaard de door mij vermelde $2^{\text {e }}$ kruisprauw met de victualie; zij richtten zich uit dien hoofde derwaarts. "Men kwam bij dezelve, de overscheping geschiedde, de Pelouwers keerden met overhaasting terug."

Het verhaal van de $4^{\circ}$ prauw luidt aldus ${ }^{3}$. Adelborst 'T HoorT had getracht "zwemmende een der afdrijvende vaartuigen te bereiken, slechts door een gering aantal der onzen gevolgd". De krachten hem verlatende, ontmoette hij den matroos VINK, die bijstand verleende; beiden bereikten "dood afgemat", hetzelfde vaartuig, waarmede zij waren gekomen en waarin nog "het lijk van hunnen ongelukkigen bevelhebber Munter lag" " 4 . In korten tijd was het getal

1 Ver Huell, dl. I, bl. 139; wij lezen daar nog van „een gewond onderofficier", die Louwкaмp zou kunnen zijn, ware het niet, dat Van Doren-M., bl. 31 , schreef, dat deze zich bevond in het door mij genoemde $4^{\circ}$ vaartuig, nl. van de 13 man. Men kan echter op geen dezer mededeelingen vast aan. Bij Stuart, bl. 393-394, vindt men medegedeeld, dat het lijk van majoor Beetjes "in deze praauw was"; dit is zeker onjuist.

2 Stuart, bl. 393, waarin ook het verder medegedeelde.

3 Ver Huell, dl. I, bl. 137-138.

- Vermoedelijk is hieraan toe te schrijven, de in noot 1 vermelde onjuiste mededeeling over het lijk van Beetjes. 
der in de boot gevluchten dertien, waaronder de luitenant der infanterie Verbruggen en de sergeant Louwkamp ${ }^{1}$. Toen men niemand meer ontwaarde, vatte ieder een pagaai; 't Hooft hield het roer. Met alle macht werd de golf uitgepagaaid. Den hoek van Boi om zijnde ${ }^{2}$, ontwaarde men twee in de richting naar Ambon zich bewegende vaartuigen, beiden roeiende, doch één tevens zeilende; dit laatste meende men te herkenuen voor het victualie-vaartuig, gelijk ook werkelijk het geval zou blijken. De vluchtenden leden aan brandenden dorst; in hun vaartuig was geen drup water, de zon gloeide; het pagaaien matte schrikkelijk af; en welk een dag van vermoeienis en ontbering hadden zij al niet achter zich! Zij deden niettemin het uiterste om de vaartuigen in te halen; men won er wel op, maar de zon ging onder, zoodat met de invallende duisternis het gevaar dreigde, dat het gezicht erop zou verloren gaan. Gelukkig ontstond er windstilte, wat het zeilvaartuig zijn vaart deed verminderen. Van 't Hooft's orembaai uit kon men ten slotte waarnemen, dat de in de kleinere boot zich bevindenden - die van het $3^{\mathrm{e}}$ vaartuig - overstapten in het zeilvaartuig. In den voornacht had 't Hooft het geluk de kruisprauw te bereiken, waarin men nu ook overstapte.

Er is een verhaal ${ }^{3}$, dat "men overcenkwam naar Amboena koerts te zetten: doch een opkomende bui noodzaakte hen af te houden naar Passo, alwaar men ontscheepte"; niet duidelijk is het echter, waarom men den omweg naar hoofdplats Ambon zou geuomen hebben; een ander verhaal makt er geen melding van, eenvoudig mededeelende ${ }^{4}$ : "De wind verhief zich gedurende den nacht, en zij bereikten den Pas Baguala, op het eiland Amboina" in den vroegen ochtend van 21 Mei.

Alzoo keerde ieder naar zijn standplaats terug. Over de Reygersbergen journaliseerde 't Hooft op dien datum: "Van het detachement op den $17^{\text {de }}$ dezer vertrokken, weder aan boord gekomen de adelborst $2^{\mathrm{e}}$ klasse 't Hooft, stuurmansleerling Haverman, 6 mariniers en 2 matrozen."

Wat den gewonden luitenant $\mathrm{t} / \mathrm{z}$ Scheidius betreft, bij de aankomst te Bagoeala trof hij er aan zijn broeder, den adelborst $l^{\mathrm{e}}$ klasse W. C. Schridius, die gereed stond naar Haroekoe te kruisen. De

IVan Doren-M., bl. 31, waar de sergeant wordt genoemd Laukamp, in afwijking van de spelling in rap.-Anthing, bl. 341.

2 Zie dl. I, bl. 471.

3 Stuart, bl. 394.

4 Ver Huell, dl. I, bl. 139. 
lijder werd naar de Nassau overgevoerd, waar hij den $29^{\mathrm{n}}$ Mei overleed: "Met den dag hesen op voorbeeld van Z. M. schip Nassau de wimpel halver stok met parade de vlag en geus voor den $L^{t}$ Gillis Nilant Scheidius, welke des nagts om 3 uur an deszelfs wond overleden was; het lijk was geopend geworden en men had bevonden, dat er twee ribben doorschoten waren, waarvan de splinters en die van het borstbeen ene verzwering veroorzaakt hadden, waarbij het koutvuur gekomen was. In den namiddag werd het lijk met alle militaire honneurs in de kerk van Amboyna begraven. Z. M. schip Nassau deed 5-minuutschoten, op het laaste schot werd vlag, wimpel en geus wederom voor gehaald" 1.

Kwamen de geredden meerendeels den $21^{\mathrm{n}}$ Mei te Ambon terug, het schijnt, dat een der prauwen via Oma den volgenden dag nog is angekomen. Althans men leest het in het journaal-'t Hooft op 22 Mei. Men zie ook bl. 619 over die "op Haroekoe gebleven zijn".

Nog vinden wij medegedeeld ${ }^{2}$, dat bij aankomst te Passo er alle mogelijke hulp werd gevonden: "zijnde de Luitenant Verbrugge aldaar reeds anngekomen, aan wien, als den oudsteu officier, overgaaf geschiedde van de papieren eu effecten van den gesneuvelden majoor en van al het overige, hetwelk in de kruisprauw was"; wij lazen echter reeds op bl. 621, dat deze luitenant tot de boot der 13 behoor.le, zoodat hij tegelijkertijd met de andere geredden aankwam; het zou overigens ook geheel in het duister blijven, hoe de luitenant "reeds aangekomen" kon zijn. Zeker is wel, dat legercommandant Anthing zijn bericht an C. C. G. G. samenstelde uit het "zeer konfus relaas, gegeven door den $2^{\text {den }}$ luitenant $V_{A N}$ DER BRUGGEN en den sergeant LouwkaMr, aan wie het gelukte te ontsuappen" 3 .

Vau de 210 deelnemers aan de expeditie, schijnen er slechts 'n dertigtal teruggekoinen te zijn ${ }^{4}$. Onder de 145 gevallenen, behoorde majoor Beetjes, trouwens gelukkig voor hem. De hoofdrebel tooide

1 Journaal ' $t$ Hooft, ad 29 Mei. - Zie ook Ver Huell, dl. I, bl. 145 . Stuart, bl. 394, meldt als datum 31 Mei.

2 Stuart, bl. 394.

3 Rap-Anthing, bl. 341. Verg. hiervóór noot 3 bl. 615 .

4 Ik ontleen dit eijfer aan het bl. 609 vermelde journaal-'t Hooft. - In rap. Anthing, bl. 341, staat echter 65. - Bij Stuart, bl. 394, leest men: „Van geheel het detachement, dat afgezonden was, om den opstand op Saparoea te dempen, bereikten slechts twee officieren, een chirurgijn, twee jonkers en tien of twaalf Europeërs behouden de residentie te Haroeko, zijnde het getal der vermisten, volgens het officieel rapport 159 man." 
zich met ziju uniform. De Europeesche flankeurs V LEIDEMEIJER door de rebellen gevangen genomen, kregen van Matulesi gratie van den dood; de eene "omdat hij zijne beprikte armen liet zien en voorgaf een Engelschman te zijn", de ander "omdat hij de trom kon slaan en daarbij kleedermaker was". Beiden bleven bij den hoofdmuiter in dienst "tot na de overwinning van Saparoea" ' De gesueuvelden werden in een kuil an het strand begraven; Matulesi droeg dit werk als straf op aan de bevolking van Noesa Laoet, "omdat zij niet bij tijds te hulp waren gekomen" 2 .

Ziehier, wat het rapport-Porto over de expeditie-Beetjes mededeelt; het is weer niet veel, maar wij lezen o. a. ook hierin van de twee gevangen genomen soldaten ${ }^{3}$ :

Den $20^{\text {n }}$ Mei des morgens omtreeks 6 uur, stak de Compagnie over naar kaap Hitoewalanej en omstreeks 8 uur ging de expeditie naar Saparoea. Toen Thomas Matualesi zag dat de orembaais op Saparoea af kwamen, gelastte hij de menschen van Haria de wacht te houden te Uraputij $^{5}$ tot Paperoe, maar de burgers volgden $\mathrm{Ph}$. Matulesi naar Saparoea om de Compagnie te bestrijden en omstreeks 9 uur kwamen de menschen uit het Noorden, van Roemakaij en Tihoelate, te Haria en gingen mee vechten te Saparoea. Omstreeks I 2 uur kwam het bericht, dat de expeditie vernietigd was: Toean Companjie soeda mati.

Des namiddags om drie uur kwamen de orang toea Sahuleka en Lucas Souhoka en vele menschen van Haria met een Hollander wiens handen gebonden waren, van Saparoea; zij brachten hem naar het gemeentehuis en gingen met hem dit rond. $\mathrm{Zij}$ waren gewapend met geweren, parangs, schilden en spiesen; vervolgens brachten zij dien Hollander naar de gevangenis en om-

${ }^{1}$ Het verhaal bij Van Doren-M., bl. 32. Op bl. 105 schijnt de slordige schrijver er geen aandacht aan geschonken te hebben, wat hij op bl. 32 als feiten verhaalde. Hij vertelt het dan eenigszins anders en brengt het „Onder de anecdoten, die men over den opstand van Saparoea in den wandel vindt". Een feit is intusschen, dat beide flankeurs gevangen genomen werden, want adelborst Feldmann, het kamp der rebellen bezoekende, heeft ze ontmoet: Ver Huell, dl. I, bl. 186; het geheele verhaal dier ontmoeting deel ik nader mede.

2 Van Doren-M., bl. 33.

${ }^{3}$ Het verhaal volgt onmiddellijk op de aanhaling, medegedeeld in noot 4, bl. 610 .

4 Beetjes ging inderdaad tusschen Haroekoe en Saparoea door en kwam alzoo voorbij de baai van Haria: bl. 611. De zuidpunt van die baai heet Hatoewalani: misschien wordt deze kaap bedoeld.

5 Wat bedoeld wordt, weet ik niet. 
streeks vijf uur kwam Th. Matulesi van Saparoea te Haria terug met de menschen van Porto en Haria, medebrengende een Hollander, dien zij echter geen kwaad deden. Den 2 I kwamen menschen van Noesa Laoet om de lijken te begraven aan de grens van de negorij Tiow, genaamd Wai Sisi.

Toen Engelhard den $3^{\text {n }}$ Juni 1817 aan Siberg het reeds hiervoren vermeld schrijven zond over het gebeurde ', deelde hij tevens het volgende mede:

"Van deze, nederlaag liep den $21^{\mathrm{n}}$ het berigt in; ons verlies word begroot op 14.0 hoofden zo Europeezen als Inlanders. Bij een lijsje hiernevens staan dezelve distinctivelijk bekend. Nog zijn daarbij omgekomen, onderscheidene burgers van Sapperoua die zich alhier bevonden en de expeditie zijn gevolgd, alsmeede de Radja van Sorry Sorry, een waardig en respectabel man, die zich hier bevond en te zelver tijd naar zijn rijkje is terug gekeerd, doch door de muitelingen is afgemaakt.

"Tot op dit moment, weet men niets af van de Residents famillie of bezetting en of zij leeven, of sacrifice geworden zijn van de muiterij. Geen enkeld persoon komt van Sapparoua naar Haroekoe of Amboine over en van de van hier gezondene, onder belofte van een - premie en dadelijke handvulling, komt ook niemand terug, zo dat men van eenig berigt dienaangaande geheel verstoken is, het geen UwHoogEdGeb. ligtelijk begrijpen kan, mij en vrouw inzonderheid treffen. Als ik miju gevoelen moet zeggen komt het mij voor, men zich met geene gunstige narigten dienaangaande vlijen moet. Van het fort te Sapparoua waaid de Engelsche vlag, zodat deze sterkte dus met zekerheid door de rebellen is ingenomen."

Dat intusschen de strijd met deze overwinning van den opstand niet ten einde was, kon de zich als bekwam bevelhebber onderscheiden hebbende hoofdrebel wel begrijpen ${ }^{2}$. De gansche zuid- en westkust van Groot-Ceram werd dan ook door hem opgeroepen om Saparoea te hulp te komen, een oproep, die buitengewoon veel weerklank vond. Meer dan 1000 berg-Alfoeren voeren derwarts en namen bij het opnieuw ontbranden van den strijd in November daaraan deel ${ }^{3}$. Het eiland Saparoea werd op de wegen, waarlangs

1 Zie bl. 612-613.

2 Anders bij Van Rees: „Te vergeefs zoekt men naar iets geniaals in zijn wezen, zelfs naar iets dat van geestkracht getuigde." "Al hetgeen men tot nu toe van Matulesia's handelingen gezien had, gaf geen hoog denkbeeld van zijne krijgskennis". Bl. 81 en 103.

3 Van Doren.M., bl. 34. 
men kon vermoeden dat onze troepen zouden komen, in staat van verdediging gesteld en de geruime tijd, die er verliep, alvorens het Nederlandsche bestuur zijn gezag opnieuw zou doen gelden, gaf gelegenheid om de werken van belang te doen zijn. Men gebruikte er toe de klipsteen, die het eilaud oplevert ${ }^{1}$. De wegen door het eiland werdeu alle van weerszijden verdedigd met mureu uit dit gesteente samengesteld, zes voet hoog, vier voet dik. Van dertig tot dertig passen legde men daarin dwarsmuren. "Een dwarsmuur, namelijk, stak van den muur in het lang, tot op een paar voeten afstands van de tegenovergestelde zijde; terwijl eeu dergelijke muur op den afstand van drie voeten er tegen over lag." Aldus was men verplicht, tusschen deze twee dwarsmuren door te gaan, wilde men den weg vervolgen, en bleef men aan het vuur van den vijand over de volgende traverse telkens blootgesteld 2. - Verder had Matulesi door het bezit van den voorraad nagelen in het fort een fonds erlangd om daaruit te betalen behoeften voor deu opstand, waaronder ammunitie, dat met name Cerammers aanbrachten. Herhaaldelijk leest men hiervan in het rapport-Porto ${ }^{3}$.

Op den $6^{\mathrm{n}}$ Augustus hadden de rebellen van Saparoea een vergadering, waarvan ons de bijzonderheden aldus in het rapport-Porto worden medegedeeld:

Den $6^{\mathrm{n}}$ Augustus vergaderden de menschen van het eiland op de grens van de negorij Tiow om te overleggen en elkander onder eede te beloven, om, indien later vrede mocht worden gesloten, of de Compagnie mocht overwinnen, dat dan niemand iets zou vertellen van de aanleiding en het begin van den strijd, tot aan het dooden van den Resident. Thomas Matulesi kwam zelf bij mij en verlangde dat ik voor hen een gebed zou uitspreken, maar ik antwoordde, dat ik niet wilde gaan; als hij mij wilde dooden, dan moest hij het maar doen, maar ik wilde niet gaan.

1 Over het gesteente op Saparoea, zie Martin (1903), bl. 81-93.

2 Ver Huell, dl. I, bl. 249, na persoonlijke opneming.

${ }^{3}$ "Den 21" Juli kwamen orang Kelmoeri (of Kelmoela) van Ceram met twee orembaais om kruit (ammunitie) te brengen. $\mathrm{Zij}$ keerden terug en (te voren) liet Thomas Matulesi nagelen halen uit het fort en gaf ben die om te ruilen tegen kruit en die orang Kelmoeri lieten twee gijzelaars achter, een genaamd Toekan en een Boina. Den 27 Juli kwamen menschen van Ceram Selor met een orembaai. Zij brachten kruit en kregen van Thomas Matulesi nagelen om tegen kruit te gaan ruilen." Dergelijke mededeelingen evenzeer op 28 Augustus, 8 September, 16, 20, 22, 25, 27 September, 2, 3 , 13 October: "Al die zendingen werden betaald met nagelen." 
Dat heb ik gezegd, ten aanhoore van vele menschen van Porto en Haria, ongeveer twee honderd.

Den $1 \mathrm{I}^{\mathrm{n}}$ was er een vergadering van menschen van Haria, waarin allen onder eede in het gemeentehuis beloofden, dat zij zich nooit er over zouden uitlaten, dat de opstand ran Haria was uitgegaan.

Diep was natuurlijk de indruk van het bericht der nederlaag op Ambon. Men zag elkander vol weemoed sprakeloos aan. Men kon er zich geen denkbeeld van maken, hoe het mogelijk was geweest, dat zulk een voor deze eilanders geduchte krijgsmacht volslagen had verdelgd kunnen worden ${ }^{1}$. Heel Ceram was nu niet alleen in oproer, maar op het eiland Ambon zelf had "booswicht Oeloepaha" evenals in 1633 "aartsvijnzer Kackialij" - zich aan en in het hoofd gesteld, om in de eerste plaats "de Hollanders van 't Land Hitoe te schoppen" 2. Tegenover zulk een hoogst gevaarlijk verzet was er te Ambon een wezenloos bestuur met een paar twistende commissarissen, met een weinig beteekenend eskader-commandant, met een niet volkomen kundig plaatselijk bevelhebber! Daar verspreidde zich reeds het gerucht, dat de rebellen van Hitoe in grooten getale het land overtrokken om naar de hoofdplats te varen; in de algemeene paniek drong al wat vluchten kon fort Victoria binneu; men bleef er tot het slechts een valsch alarm bleek ${ }^{3}$.

Dat men onder zulke omstandigheden behoefte gevoelde zijn gemoed aan ieder en onder elke omstandigheid uit te storten, laat zich begrijpen. Hoe Engelhard dat doet, kunnen wij o. a. ook lezen in den volgenden brief, dien hij d.d. 26 Mei 1817 uit Ambon zond aan $\mathrm{M}^{\mathrm{r}}$. Bousquet ${ }^{4}$ :

\section{WelEdele Gestrenge Heer \\ G'Eerde vriend}

Ik vereere mij, UweEdele Gestrenge, bekend te maken, met ons arrivement alhier op den $8^{e}$ Maart j.l. Met zulke snelzeilende scheepen, als van onze vloot, was de overtogt niet in evenreedigheid voorspoedig; veroorzaakt eensdeels door de aangetroffen stiltens, en anderendeels, de al te groote voorzigtigheid van onze

1 Ver. Huell, dl. I, bl. 145. - Mr. Mijer, gaarne de zaken van den besten kant willende beschrijven, gewaagde daarentegen van "eene kleine expeditie", „uit eenige militairen en zeevarenden bestaande". Kronijk, bl. 347.

${ }^{2}$ Rumphius, dl. I, bl. 104. - Verg. hiervóór dl. I, bl. 414.

3 Boelen-M., bl. 245. - Verg. dl. I, bl. 415-416.

4 Verg. dl. I, bl. 344. 
Commandant Dietz om niet van alle geleegenheeden gebruik te maken, en bij 't minste buijige weer zeilen te minderen. De Heer Dietz heeft het hier niet lange gemaakt, zijnde hij tusschen den 24 en 25 Maart, op de reijze naar Banda, werwaards hij als commissaris tot de overnaam van die Residentie en onderhorigheden was bestemd. overleeden. Zijn lijk is aan wal gebragt, en alhier zo plegtig mogelijk, met militaire honneurs begraven.

Met de overnaam van de Molukkos is alle spoed gemaakt, als zijnde den 25 Maart bereids in het bezit getreden van Amboina. De overige etablissementen zijn zo voor als naar deze tijt tot het Nederlandsche Gezag terug gekeerd. Het heeft Commissarissen tot de overnaam van de Molukkos mogen gelukken, een brieljante overnaam te doen, waarvan het Gouvernement alle voordeelen kan genieten. Dan ik denk er niet aan, zonder vrees; niet uit bedugting, dat onze verrigtingen door Hunne Excellentien Commissarissen Generaal zullen worden afgekeurd. Dit zij verre. Hoogstdezelve zijn al te billijk, dat zij daden, met het beste oogmerk daargesteld, en in de gevolgen rampspoedig, niet zullen blijven toetsen aan de weezenlijke bedoeling.

Het is mogen gelukken, van het Engelsche Gouvernement te contracteren een derde van de nagel-recolte, of ruim I00.000 Ponden Hollands, t€gen de betaling van 30 stuivers per $\boldsymbol{t}^{2}$. Van deze nagelen leggen op de residentien Saparoea it 9728 , Haroeka ii 89244 en op Hila it 2500. Uit hoofde van de onlusten te Saparoea, zo als UwEdelGestr. ongetwijffeld zal vernomen hebben, zijn de eerstgemelde waarschijnlijk verloren, en de laastgemelde niet buiten gevaar. Het Engelsche schip De Swalluw is gezonden na Haroeko om de nagelen in te neemen. Het is te hoopen, dit schip aldaar zal zijn aangekomen, voor dat de onlusten waarmede deze residentie bedreigd wierd, zijn doorgebroken en door het aanwezen van dit schip aldaar het bedreigd gevaar, voor deze plaatse zal zijn afgekeerd.

De positie waarinne men zich alhier bevind, is allerakeligst; onze scheepen zijn te groot om in deze wateren te kruisen of met vrugt eenige expeditie te doen; waren wij nu voorzien van twee a drie g'armeerde brikken, zo als de Engelsche brik Nautilus, waarmeede deze naer Batavia overgaat, en die wij van het Engelsch Goevernement te koop gevraagd hebben, konden wij ons gemakkelijk redden. De Corvet Iris is al hier aangekomen, maar in eene zoo reddelooze staat, dat van dit vaartuig geen gebruik heeft konnen werden gemaakt in de eerste ogenblikken, en dat hetzelve van dienst konde zijn. Op heeden is dezelve de baay uitgeraakt, om naar Haroeko te verzijlen, en zich daar te sta- 
tionneren tot beveiliging van die Residentie, en dekking van deze cust, teegens de muitelingen te Saparoea.

Mijne commissie alhier, moet ik uw als vriend verklaren, word daardoor niet lekker, dan hier over bij monde nader.

De dood van de Resident van Banda Berkhoff zal UwEdeleGestr. ook waarschijnlijk vernomen hebben. Zijn Excell. is maar vijf dagen ziek geweest; het is een groot verlies voor het Gouvernement; Zijn Excell. behartigde de zaken op Banda met alle ijver en gaf blijken van bekwaamheid.

Ik wil hoopen het genoegen te mogen hebben, UwWelEdele Gestr. Beminde en verdere betrekkingen in een beste staat van gezondheid te zullen aantreffen. Mijn vrouw en ik bevinden ons ook welvarende gelijk ook uw zoon de adelborst op Z. M. schip Nassau, die wij dagelijks bij ons ontmoeten. Hij is gelukkig niet geweest in de expeditie na Saparoea, anders was hij nu ook geweest de sacrifice van de facheuse gebeurtenissen aldaar. Eenen Luitenant Munter, eenen de Jong, de majoor Beetjes en de capitein Staalman, en meer anderen hebben daar hunne dood gevonden op eene elendige wijze.

Hiermede deze eindigende, vereere mij na aflegging van de veelvuldige complimenten van mijn vrouw aan UwWelEdele Gestr. dierbare wederhelft, de Gouvernante en uwe kinderen met de meeste achting mij te noemen

WelEdele Gestrenge Heer

G'eerde vriend

UWelEdele Gestr. Dienaar en vriend

Hoezeer zal knappe Mr. Bousquet, die zulke geestvolle en goed gestileerde brieven kon schrijven, gelijk wij ze lezen in de BrievenV.d. Graaff, zich geamuseerd hebben met de epistels van Engelhard, wiens positie "niet lekker" was geworden en die de groeten verzocht aan Bousquet's "Beminde"! 


\section{HOOFDSTUK VI.}

\section{Localiseering van den geest van verzet op Ambon.}

Versterking van de militaîre macht te Ambon. - Weigering door ons bestuur van hulp, te verleenen door Ternate, Tidore en Ceram. Het overbrengen van staatsgevangenen aan boord der oorlogsschepen. - Verzet op Hitoe: Juni-Juli. - Staat der rebellie aldaar en op ZuidCeram tot den aanvang van Augustus. - Resident De Haart.

De Moluksche commissie was vau oordeel, dat aan een dadelijk hernieuwd optreden tegen Saparoea niet te denken viel : men behoorde af te wachten de terugkomst van de Reygersbergen, die, gelijk wij weten ${ }^{1}$, zich in de wateren van Teruate en Menado ophield, dan wel de hulp van eenig ander gewapend vaartuig, terwijl men intusschen moest trachten te behouden, hetgeen nog niet verloren bleek, met name Haroekoe en Ambon zelf, waar de terugslag der nederlaag ondervonden werd ${ }^{2}$. Aangezien de geheele militaire macht op Ambon en de Oeliasers nu heette te bestaan, behalve uit $\mathbf{5 5}$ artilleristen, uit 55 Europeanen en 250 Inlanders, was de toestand inderdaad bedenkelijk genoeg, ook op Ambon, zoodat daar vóór alles maatregelen noodig bleken.

De burgerij werd opgeroepen zich tot een gewapende macht te vormen en de waarnemende magistraat $R$. H. CATEAU vaN RoseveLT, gewezen luitenant $1^{\mathrm{e}}$ klasse op de Nassau, tot chef ervan benoemd, met last een plan van organisatie te ontwerpen ${ }^{3}$. Aldus kreeg men een korps van 800 hoofden, waarvan er echter slechts 300 van geweren konden worden voorzien; de overigen ontvingen pieken. De Gouverneur deed verder een inschrijving voor vrijwilligers openen ten einde, zoo het noodig mocht blijken, in fort Victoria dienst te doen; het leidde tot een korps van 250 à 300 man met den "secretaris" Scholer als commandant en bestaande uit ondergeschikte ambtenaren der $2^{\mathrm{e}}$ en $3^{\mathrm{e}}$ klasse, zonen van notabelen, regenten,

1 Verg. dl. I, bl. 493 en dl. II, bl. 569.

2 Uit Engelhard's Bataviaasch verslag.

3 Van Doren-M., bl. 39. - De voornamen van den heer Van Rosevelt en zijn vroegere betrekking staan met potlood in margine aangeteekend in het Van Doren-exemplaar van het Indisch Genootschap. 
nabestaanden: "het neusje van den zalm", zooals het nogal zonderling, wordt geheeten ${ }^{1}$, en waarvan mede als doel wordt omschreven " om hen langs dien kant meer aan de belangen van het gouvernement te verbinden en hen tevens onder het oog en in bedwang te houden": 100 man moesten worden gewapend met geweren, de overigen zoude men oefenen in de bediening van het geschut. Een derde korps had iets van een landmilitie, "ook bij wijze van vrijwillige inschrijving" samen te stelleu uit de bevolking der negorijen en wel uit zonen en nabestaanden van orang toewa's, kepala soa's en kepala dati's 2 : deze militie had ten doel om ingeval het van Hitoe dreigde, derwaarts op te trekken in samenwerking met de militaire macht. Bovendien vormde de Gouverneur uit de te Ambon achtergebleven Bengaleezen een korps politiedienaren sterk 40 man, "ten einde bij elke omstandigheid door hen te voet of te paard patrouilles door de stad te laten doen".

Bij besluit van 8 Juni 1817 keude de Commissie aan de aldus in militairen dienst zijnde burgers dezelfde traktementen en rantsoenen toe als voor de Europeesche militairen bepaald, met nog een toelaag van $1 \frac{1}{2}$ ropy 's maands, "alzo deze menschen zich in ene zeer armoedige staat bevonden en enige noodzakelijke behoeftigheden hadden aan te schaffen" 3 .

Er was nog een andere hulp ter beschikking, namelijk vau inlandsche potentaten. Als ter bedwinging van een zeer gevaarlijken opstand in het Romeinsehe rijk de daartegen optredende bevelhebber dergelijke hulp weigert, teekent een beschrijver ervan aan : dat dit was "not the result of disdainful self-confidence, but rather of great wisdom and insight into the native character"; dat alzoo getoond werd "they were not iudispensable"; dat Britsche officieren "used similar methods with native troops, and with good results" 4. 't Is ongetwijfeld een quaestie, die van meer dan één zijde valt te beschouwen. Gouverneur Van Middelkoop was "zelfs op de dringendste vertogen" er niet toe te brengen, den bijstand der vorsten van Ternate en Tidore in te roepen, gelijk het ten slotte Buijskes gedaan heeft. Engelhard, die ous Van Middelkoop's onwil ten deze mededeelt ${ }^{5}$, voegt er het motief aan toe, dat op de trouw dier vorsten weinig

1 Als de vorige noot.

2 Van Doren-M., bl. 39-40. - Verg. dl. I, bl. 486.

3 Engelhard in zijn Bataviaasch verslag.

" "Civil War and Rebellion in the Roman Empire A. D. 69-70", door BERNARD W. Henderson (1908), bl. 297. Ik haalde dit werk ook aan op bl. 617, noot 4 .

${ }^{5}$ Als nooit 3. 
staat te maken was, "en welligt niet ongegrond", meende ook hij. Echter had de Moluksche commissie bij brief d.d. 13. Juni het advies er over ingewommen van den resident van Ternate Neijs, en door deze was d.d. 30 Juni een antwoord gegeven, waarin hun trouw op het gunstigst werd afgeschilderd, tevens berichtende, dat zij met verlangen het tijdstip te gemoet zagen om van hun toewijding blijk te geven. Het had echter geeu dadelijk resultaat. Ook lezen wij bij Ver Huell: "De Radja Eti, een der Koningen van de Alfoeren, of bergbewoners van Ceram, kwam met een groot vaartuig, Jonco genaamd, zijne hulp aanbieden tegen de rebellen: doch men vond het niet raadzaam dezen bijstand aan te nemen, en een opperhoofd van deze woeste volkeren te vertrouwen" '. In overeenstemming hiermede heeft 't Hooft in zijn journaal ad 11 Juni aangeteekeud: "Hoorden, dat er een koning der Alfoeren was aan de wal op Amboyna, welke met den gouverneur en Commissarissen eene conferentsie had gehad, waar hij had aangeboden 3000 zijner onderdanen naar de oproerige eilanden te zullen zenden om de rebellen te verdelgen."

Buijskes heeft, naar wij lezen zullen, aanstonds de vorsten van Ternate en Tidore tot het verleenen van hulp opgevorderd; nadeelige politieke gevolgen schijnt het verleenen ervan niet gehad te hebben, althans zoover het rechtstreeks aan den dag kon treden. Wel zullen wij van een paar uitingen kennis nemen, die er op moeten wijzen, dat deze benden geenszins zoo krijgshaftig waren, als zij zich wel wilden toonen; het zoude echter verregaand overdreven zijn te beweren, dat Buijskes niets aan die hulp gehad heeft; bovendien kreeg hij er een massa vaartuigen door, die voor het afsnijden van gemeenschap van groot nut waren. Overigeus kon de Schout-bij-nacht met meer gerustheid van deze hulp gebruik maken dan de Moluksche commissie, omdat hijzelf een goede versterking van schepen en troepen aanbracht.

Meende alzoo het bestuur te Ambon van geen anderen bijstand gebruik te moeten maken dan dien de meer onmiddellijke omgeving aanbood, bij wijze van voorzorg had het echter bovendien te letten op eenige voorname staatsgevangenen, die reeds tijdens het Britsche bestuur gerelegeerd waren.

Hiertoe behoorde in de eerste plaats een gewezen sultan van Jogja, Amangkoe Boewana ${ }^{2}$; hij werd nu van zijn woning te Ambon

1 Ver Huell, dl. I, bl. 172; aldaar ook een aardige af beelding van de jonco.

2 Verg. dl. I, bl. 403, 408 en 515. 
naar den Evertsen overgebracht, wardoor Ver Huell hem leerde kennen. "Hij was", deelde hij in zijn Herinneringen mede ${ }^{1}$ : " "een grijsaard van hooge jaren, dien men, in deze tijden van oproer, onder de inboorlingen niet vertrouwen kon. Vele zijner hovelingen en vrouwen volgden hem aan boord, onder anderen Radinaio Ratnoe (Radenajoe Ratoe?) Deningrat, gewezen Bevelhebster zijner vrouwelijke garde, eene zeer schoone rijzige vrouw. Al hoewel deze gevallen Vorst van al zijne grootheid beroofd was, hadden zijne Grooten denzelfden slaafschen eerbied voor hem, als of hij nog op den troon zat. Hij vereerde mij dikwijls met een bezoek, en ik onthaalde den ongelukkigen Sultan op thee en confituren." Deze pietswaardige werd 'n tiental jaren later, o. a. ook op instemmend advies van Engelhard, weder te Jogja ten troon verheven, daar te Batavia gehoopt werd, dat aldus een einde zou gemaakt kunnen worden aan den opstand van Dipanegara, een verwachting, die zich niet verwezenlijkt heeft.

Een ander vorst, dien Ver Huell mede aan boord kreeg, was de op bl. 516 en 608-609 vermelde gewezen koning van Gilolo, Mohammed Oscar met gemalin Fatima, naar Ambon verbannen "doordien hij in onmin geraakt was met den Sultan van Tidor" 2.

Commandant Kraijenhoff gaf tevens bevelen tot versterking van

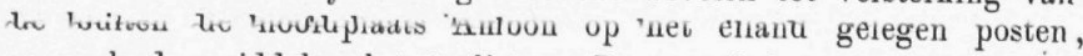
zooveel de middelen het toelieten. Daartoe behoorden Bagoeala ${ }^{3}$, zoomede Hila, Hitoe lama en Liang ${ }^{4}$; van inlandsche zijde ondervond hij in deze werkzaamheden "eene groote onverschilligheid en onwilligheid en geneigdheid voor het voormalige Engelsche gezag".

Op Leytimor, gelegen onder de kanonnen van de Evertsen en andere schepen, kwam het, ofschoon het er ook dreigde (bl. 634), niet tot oproer; op Hitoe daarentegen wel. Daar was een tot verzet genegen bevolking. Engelhard herinnert er aan in zijn Bataviaasch verslag, hoe evenzeer onder het Engelsch bestuur, doch kort na de overgave in 1796, de menschen er waren opgestaan onder Oeloepaha en zelfs fort Victoria bedreigden, waarop een aanval misschien gelukt zou zijn, wegens den zwakken staat van het garnizoen, ware niet toevallig een Engelsch linieschip de baai binnen gezeild, die aan de muitelingen belette van Hitoe over te

1 Ver Huell, dl. I, bl. 147.

2 Ver Huell, dl. I, bl. 148.

s Verg. dl. I, bl. 418-419.

4 Zie dl. I, bl. $460-463$. 
steken '. "Hun Oeloepaha", verhaalt Engelhard verder, "werd gevangen genomen en in een ijzeren kooi opgehangen; bovendien nog 50 anderen geëxecuteerd, ongerekend 200 die op het slagveld het leven lieten." Wij zullen zien, dat de hoofdrebel van 1817 , Matulesi, ook in een kooi werd gehangen: de manier is wat vreemd, maar nu weten wij ten miuste het antecedent!

In den aanvang van Juni 1817 dan werden niet slechts onze posten te Larike en Hila aangevallen, maar ten slotte werden gekwetst zoowel de resident BurghgraAf als de militaire commandant WALraven ${ }^{2}$. Intusschen slaagden beider gezamenlijke pogingen tot handhaving van het gezag; zelfs namen zij muitelingen gevangen, waarvan de hoofdleiders dadelijk aan een boom werden opgehangen ${ }^{3}$. Den Resident werd intusschen het uitbreken dezer onlusten verweten, zoodat 't Hooft in zijn journaal ad 24. Juni aanteekende: "Op Hila (de noordkust van Amboyna) waren onlusten geweest, waarbij den resident Burggraaf verscheidene wonden kreeg als ook den kom. der troepen Walraven; de belhamer, die men bij het terugslaan van den vijand gevat had, was dadelijk aan een boom opgehangen. Volgens gerugten zoude den Resident van alles de oorzaak zijn, waarom den heer De Hard + als zodanig zijne plaats vervangde."

Naar aanleiding dezer gebeurtenissen, schreef Engelhard in zijn brief an Elout van 23 Juni o. a. het volgende:

De kruisser Antilope, eenige dagen langer vertoevende dan de intentie was, is deze onafgedaan blijven liggen. Wij schreven heeden den $25^{\mathrm{n}}$ Meij ${ }^{5}$. Gisteren tegens den avond liep alhier het berigt in dat de muitelingen des morgens de residentie Hilla hadden aangevallen, doch gelukkig door onze bezetting aldaar waren afgeslagen, zijnde bij die gelegenheid de resident Burghgraaf en de Commandant van de bezetting capitein Walraven met een piek verwond. De misnoegdheid tegens de resident is $\ldots,{ }^{6}$ daarvan de oorzaken te zijn. Commissarissen zijn onder andren overeengekomen den gem. resident Burghgraaf uit hoofde van zijne bekomene wonde te laten vervangen door de heer Smith de Haart,

1 Verg. dl. I, bl. 476.

2 Over Burghgraaf, dl. I, bl. 370-371; over Walraven, dl. II, bl. 609.

3.Ver Huell, dl. I, bl. 150.

4 De Haart; verg. dl. I, bl. 371.

- Dit zal een verschrijving zijn en 23 Juni moeten wezen.

${ }^{6}$ De copiïst, geen Hollandsch kennende en Engelhard's schrift niet kunnende lezen, heeft hier deze woorden gesteld : „lang van scheidene camalle opgegeven"!! 
die ook bereids deze morgen derwaarts is vertrokken om van ZEd. het gezag onmiddelijk bij aankomst over te nemen en naar Amboina op te komen; voorts na aankoming een onderzoek te doen wat aanleiding heeft gegeven tot deze volksoploop en daarvan een ampel rapport in te zenden aan de Gouverneur van de Molukken. Ik had gehoopt dat het kwaad zich zoude hebben blijven bepalen tot Haroekoe en Saparoua. Het blijkt dus hieruit dat het kwaad algemeen is en moet men de zijdelingsche berigte geloof geven, zou het ook op dit gedeelte van de post niet zuiver zijn. Dit maakt de zaak bekommerlijk en moeijelijk omdat men zich nu hier niet ontbloten durft om allerwegen de posten zo te versterken als kwam te vereyschen om de muitelingen ressistentie te bieden.

Het hoofd der oproerlingen in het Hitoesche was een 80 -jarige inboorling van Seit, een negorij tusschen Hila en Larike gelegen, eveneens Oeloepaha geheeten '. Daar hij te voet niet meer gaan kon, bezielde hij in den strijd de rebellen, op een draagstoel gezeten; in het hevigst van het vuur liet hij zich van de eene plaats naar de andere voeren om bevelen te geven en zijn volk aan te moedigen. Hoe de geschiedenis zich ook hier op Hitoe herhaalt: in zoover toch, dat toen in 1600 de Hitoeëezen in opstand verkeerden tegen de Portugeezen, steeds wachtende naar de hulp, die Steven van der Hagen uit Nederland zou aanbrengen, het volk het oog had "op den stok ouden Tahalille", die wilde "sijn leven, dat dog so wel als g'eyndigt was teu besten van het land spendeeren". Zoo schrijft Rumphius ${ }^{2}$; als echter zulk een oud man de rebellen aanvoert tegen onszelven, dan laat het zich verklaren, dat er gesproken wordt van een "booswicht", gelijk Buijskes zal schrijven over Oeloepaha. Diens invloed strekte zich niet alleen uit over gansch Hitoe, maar ook over Ceram's zuidkust, vanwaar Ambon en de Oeliasers aanvoer kregen in sago, strijders en ammunitie, trouweus mede aangevoerd van Bali, Timor, enz. ${ }^{3}$. Onze hoofdversterking op Ceram, Loehoe, schijnt op het einde van de maand Juli onder de leiding der Hitoeëezen gevallen te zijn. Althans in het rapport-

1 Verg. dl. I, bl. 462-463. Deze Oeloepaha was òf zoon, òf broeder van den muiteling van 1796: zie hicrvóór op bl. 572 al. 5 en hierna op bl. 636 voorlaatste alinea.

2 Rumphius, dl. I, bl. 14. Verg. hiervóór dl. I, bl. 422.

3 In het rapport-Porto, vind ik in den aanvang van October melding gemaakt van 'n radja Ondor(?), die kruit aanbracht en een brief medekreeg "voor Radja Bali en werd vergezeld door 2 inlandsche burgers". Verg. hiervóór, bl. 625 . 
Porto leest meu: "Den $28^{\text {n }}$ Juli kwam de oudere broeder van den kapitein van Pelaoe te Haria en bracht een brief met de mededeeling aan Thomas Matulesi, dat de menschen van Hitoe de kota van Loehoe hadden genomen en Pieter Weynand hadden gedood."

Ten einde de kust van Hitoe te beveiligen en de gemeenschap tusschen Hitoe en Ceram zooveel mogelijk af te snijden, werden particuliere scheepjes gehuurd, die de Commissie deed wapenen. Daartoe behoorde de Noorsche brik De Zweed; "als loods of commandant" werd daarop geplaatst de oud-luitenant t/z J. GERARD 1. Op de reede van Hila stationneerde de Commissie de Engelsche brik Tweed. Toen de huurtijd van twee maanden om was, zag de eigenaar, 'n Arabier, er voordeel in, de brik voor goeden prijs onze Commissie te koop aan te bieden, daarbij te kennen gevende, hij de huur niet wilde verlengen. Zij zag zich wel genoodzaakt hierop in te gaan, "alzo de voorzigtigheid voorschreef om de rhede van Hilla niet van magt te ontblooten, gelijk zulks bij besluit van den $28^{\mathrm{n}}$ Mei $\mathrm{N}^{\mathrm{o}} .61$ en 25 Junij $\mathrm{N}^{\circ} .92$ staat genoteerd ${ }^{2}$. Op de reede van Larike werd gestationneerd de an een Chinees toebehoorende brik Lassem. Aangezien de gemeenschap over land tusschen deze plaats en Hila was verbroken, deden Commissarissen bij besluit d.d. 1 Juli 1817 haar onderhouden door een mede aan een Chinees behoorende sloep of barkas "om steeds in dat vaarwater van eene plaats naar de andere manschappen en behoeften over te brengen, alzoo de correspondentie over land tusschen deze twee residentie's was afgesneden, door de tusschen beide liggende oproerige negorijen" 3 .

Te Liang op de noord-oostkust van Hitoe voerde luitenant WondERLING het bevel. Denzelfden dag, dat de Commissie de barkas had gehuurd, dus 1 Juli, vielen de muitelingen dezen post aan. Wouderling zag zich verplicht met zijn 4.0 man en een officier de plaats te verlaten, dat echter niet geschiedde dan na een strijd, waarin 35 à 40 man der rebellen het leven verloren of gekwetst werden; onder de ge-

${ }^{1}$ De huur bedroeg $500 \mathrm{Sp}$. matten 's maands, behalve de assurantie van 4000 Sp. matten tegen eenig ongeluk, dat het schip mocht overkomen. Gerard was aangesteld op een maandelijksch traktement van 150 ropijen. Men vindt van deze inhuring gewag gemaakt in het besluit van C. C. G. G. d. d. 25 Juni 1817, naar aanleiding van een schrijven der Moluksche commissie den $6^{\mathrm{a}}$ te voren: Zie Brieven- $\nabla$. d. Graaff, dl. I, bl. 44 .

${ }^{2}$ Engelhard in zijn Bataviaasch verslag. Bij de verwarring echter, die in de Engelhard-stukken heerseht, is de mogelijkheid volstrekt niet buitengesloten, dat de Tweed, inderdaad de Zweed is. De eigenaar was echter een Arabier.

${ }^{3}$ In het Bataviaasch verslag. Larike was tijdelijk een zelfstandig gewest geworden. 
sneuvelden behoorde de anvoerder; het schijnt, dat Wonderling op weg was naar het zuidwaarts gelegen $W a i$, althans derwaarts werd gebracht het lijk of een gedeelte van deu gesneuvelden aanvoerder, "alwaar zijn hoofd, tot voorbeeld voor andereu, is opgehangen en ten toon gesteld" '.

Te Wai commandeerde luitenant De Bres. Op het veruemen vau de vermeestering door de rebellen van Liang, gaf men te Ambon last aan kapitein LISNET om zich dadelijk naar Wai te begeven "ten einde de post van Liang met voorzigtigheid en beleid weder te doen bezetten door $51 \mathrm{man}$, de officieren daaronder begrepen, en wanneer zulks niet voldoende mogt zijn, een gedeelte van het detachement van de post Baguala daarbij te voegen". De Legercommandant te Batavia deelde dit mede aan C. C. G. G. bij zijn rapport van 21 Juli, daaraan nog toevoegende: "Ook op Tioe rebelleren de ingezetenen, waarom aldaar een post bezet is geworden met 1 sergeant 1 korporaal en $11 \mathrm{man}$, ten einde te zorgen, dat de kommunikatie tusschen Haroekoe, Liang, Waai en Tuilehoe met de post Baguala niet afgesneden worde. Deze noodzakelijke bezettingen verzwakken echter van dag tot dag het garnizoen van de hoofdplaats." 2

Ontleende de Legercommandant deze mededeelingen aan het rapport van overste Kraijenhoff d.d. $3 \mathrm{Juli}$, iets naders over de zaken in den loop dier maand wordt echter niet vernomen. Men vindt slechts het volgende door Van Doren geschetst over den stand der rebellie op Hitoe en Zuid-Ceram, na de herneming onzerzijds van fort Duurstede op 3 Augustus, gelijk ik daarvan hierna de beschrijving zal geven ${ }^{3}$ :

Ten aanzien van den staat van zaken te Hila bleven de rebellen aldaar cijnsbaar en onderworpen aan den hoofdrebel Matulesia, en werden daarenboven in vrees en bedwang gehouden door zekeren Ouloepuha van Ceith. Deze was de broeder van een in het jaar 1796, onder het Engelsch tusschenbestuur voor een gelijke behandeling te Hila opgehangene.

Onder de afvallige negorijen waren die van Ceith, Hatoewa, Lebelehoe en Lima ", benevens de negorijen Piroe, Tanoenoa, Etti,

1 Tïdschr.-Indië, bl. 344-345. Ook de daarna volgende aanhalingen.

2 Gelijk gezegd, in Tijdschr.-Indië. Met Tioe is, denk ik, bedoeld Tial, liggende aan de noordkust van de baai van Bagoeala en alzoo ten zuiden van Wai; Tuilehoe, of liever Toelehoe, ligt aan de zuidkust van de bocht van Wai en alzoo ten noorden van Tial. Verg. dl. I, bl. 419-420.

3 Van Doren-M., bl. 72-74.

4 Wat hier met Hatoewa bedoeld wordt, weet ik niet; over Lebelehoe, zie dl. I, bl. 462. 
Loehoe en Lokki aan de oostkust van Hoeamohel of klein Ceram gelegen '; terwijl de negorijen Liang, Morella, Mamala ${ }^{2}$, Hitoe lama, Dakal ${ }^{3}$ en Kaybobo onder Hila en Iha op de zuidkust van Groot Ceram " door een goed voorbeeld van hunne Regenten voorgegaan, getrouw aan het gouvernement waren gebleven. Dien ten gevolge werden deze bijzonder in het algemeen rapport van den Landvoogd aanbevolen.

Buiten de bezetting van Hila in het blokhuis "Amsterdam", bevond zich ook eene bezetting te Liang, Mamala en in het vervallen blokhuis «Leiden" te Hitoe lama, welke sterkten in staat van verdediging waren gebragt, waardoor de kust van Hitoe tegen aanvallen gedekt was, voor zoo verre zij door geene overmagt werd aangetast; waarvoor toen weinig te vreezen was, te meer omdat door het overmeesteren van het fort «Duurstede" en het beleid der land- en zeemagt aan den dag gelegd, een zoodanige schrik onder de muitelingen gebragt was, dat $\mathrm{zij}$ vooreerst geene aanvallen zouden beproeven.

De waarnemend Resident van Hila, De Haart, die daaromtrent door den Landvoogd was geraadpleegd, was ook van gevoelen, dat wanneer men slechts met kracht eenen algemeenen aanval beproefde op de muitelingèn van de zee- en landkant, in de negorijen Ceith, Hatoena, Lebelehoe en Lima - zij hadden hier eene sterke verschansing opgeworpen - er geene vrees bestond, dat onze wapenen zouden zegevieren, en de muiters geheel ten onder gebragt werden, een plan, dat reeds vroeger door den Lt. Kolonel Kraaijenhoff was geopperd, doch, zoowel door gebrek aan gewapende vaartuigen, als door de verpligting, waarin men zich toen bevond, de troepen tot versterking en ontzetting van Honimoa en het fort "Nieuw-Zeelandia" te gebruiken, nog niet ten uitvoer gelegd.

Wat resident De Haart betreft, wij verliezen hem tijdens de krijgsgebeurtenissen uit het oog. Alleen vind ik nog in het journaal van Boelen aangeteekend, dat deze, in de baai van Saparoea zijnde, den $31^{n}$ Juli een brief van Ambon ontving, waarin bericht werd,

1 Piroe, Eti, Tanoenoe liggen niet op Hoeamoal, maar aan de oostkust van de baai van Piroe; slechts Loki met Loehoe liggen aan de oostkust van Hoeamoal.

2 Ten onrechte staat gedrukt bij Van Doren-M., bl. 73: Morella mamala!

3 Dakal, zal wel zijn Wakal, west van Hitoe lama.

4 Kaibobo ligt aan den ingang van de baai van Piroe, tegenover P. Babi; Iha inderdaad op Ceram's zuidkust; waar destijds Iha onder sorteerde, zegt de Schrijver niet; maar later in ieder geval ook onder Hila op Ambon, blijkens Veth's Aardrijkskundig Woordenboek. 
639 HET HERstel VAN HET NEDERL. GEZAG IN DE MOLUKKEN IN 1817.

dat de Resident een anval had afgeweerd en aan de rebellen veel schade had toegebracht: "3 van hunue opperhoofden werden gevat en dadelijk onthoofd, hunne hoofden werden aan de nokken der raas gehangen." - Onder Buijskes werd De Haart benoemd tot resident van Saparoea, "een geruime tijd de residentie van Hila na genoegen hebbende waargenomen". Na deze waarneming van Hila, scheen hij nog geweest te zijn "winkelier en directeur van de Wisselbank" te Ambon, in welke qualiteit de Schout-bij-nacht hem, blijkens het Buitenzorgsche verslag, aantrof ${ }^{1}$.

1 Winkelier: zie dl. I, bl. 449. 
HOOFDSTUK VII.

\section{De onlusten op Haroekoe: 21 Mei tot medio Juni.}

Adelborst Scheidius naar Haroekoe: 22-23 Mei. - Fort Zeelandia onder adelborst Musquetier. - De Britsehe koopvaarder de Zwaluw en het Britsche Compagniesschip Nautilus. - Vertrek van de gewapende Zwaluw d.d. 22 Mei naar Haroekoe. - Vertrek van de Iris derwaarts: 25 Mei. - Komst te Haroekoe van kapitein Van Driel en adelborst Scheidius; vertrek van Musquetier. - De radja van Haroekoe. Halalioe, Pelaoe, Kabaoe in opstand. - De anval der rebellen d.d. 30 Mei. - En op 3 Juni. - Engelhard's mededeelingen over deze aanvallen. - Aanvallen op 9 en 14 Juni. - Bestraffing van Oma. - Zoomede van Kabaoe en Rohomoni: 15 Juni. - Het rapport-Porto over Matulesi's teleurstelling. - Engelhard's denkbeeld om de bevolking der Oeliasers uitteroeien. - Engelhard's niet volbrachte plannen om naar het tooneel van den opstand te gaan.

Gelijk wij ons zullen herinneren ${ }^{1}$, had het eenige vaartuig, waarvan men vindt melding gemaakt als teruggekomen te zijn van Saparoea, na de ongelukkige expeditie-Beetjes, op den $21^{\text {n }}$ Mei aan de pas van Bagoeala ontmoet den adelborst W. C. Scheidius, "welke bezig was, eene gewapende barkas over den Pas te slepen, waarmede hij naar de baai van Saparoua moest vertrekken", "om in deze gewapende barkas tusschen de eilanden Haroeka en Honimoa te kruisen" ${ }^{2}$. De mislukking der expeditie-Beetjes deed hierin verandering brengen. Gouverneur Van Middelkoop gelastte toch Scheidius den $22^{n}$ Mei $"$ om de barkas achter te laten, en met het detachement, 30 man sterk, onder zijne bevelen, zich naar het eiland Haroeka te begeven". De Adelborst liet dientengevolge het vaartuig achter onder de hoede van den sergeant, die op den Pas bleef post houden, terwijl hijzelf naar een andere gelegenheid moest zoeken, om naar Haroekoe over te steken. Daartoe trok Scheidius met zijn detachement noordwaarts de kust op "en marcheerde naar de negorij Soelie, en des anderen daags naar Toleo, welke negorij dwars van Haroeka gelegen is" s. De radja van dit laatste dorp bezorgde een vaartuig, geschikt tot de reis naar de hoofdplaats Haroekoe.

\footnotetext{
I Zie bl. 621.

2 Deze en volgende mededeelingen bij Ver Huell, dl. I, bl. 139-141.

3 Zie dl. I, bl. 419.
} 
Herinneren wij ons mede ${ }^{1}$, dat Beetjes in het fort Zeelandia had achtergelaten adelborst Musquetier met 'n 50 man. "Deze sterkte was", beschrijft Ver Huell 2, "in een ellendigen staat van tegenweer". "Bijua geene der kanonstukken waren bruikbaar, de affuiten verrot en vergaan. Dadelijk werd er handen aan het werk geslagen, om van eenige stukken hout rolpaarden te vervaardigen, om des noods van de beste kanouneu nog eenige dienst te kunnen hebben. Deze stukken werden buiten het fort geposteerd op die punten, waar men vermoeden kon, dat de muitelingen een' aanval zouden kunnen wagen; alzoo de sterkte alleen naar de zeezijde wederstand kon bieden, waar men nu niets te vreezen had. Het werd evenwel noodzakelijk geoordeeld, eenige affuiten enz. aan te vragen, alzoo de aanwezige, hoe goed mogelijk in elkander gebragt, altoos gebrekkig bleven." Dit verzoek kwam nog den $22^{n}$ Mei te Ambon; er werd dadelijk aan gevolg gegeven, blijkens de volgende aanteekening in het journaal van 't Hooft ad 22 Mei : "De matroos Humeler in expresse van Haroeka met een brief van den adelborst Musquetier, aan den Comman ${ }^{t}$ der troepen versterking verzoekende, daar de vijand gedreigd had te zullen ataqueeren; werd nog 12 man naer vernoemde eiland gezonden."

De verzochte hulp is naar Haroekoe gevaren den $23^{\mathrm{n}}$ Mei met het Engelsche transportvaartuig The Swallow, kapitein WILson, dat resident Berkhoff van Batavia naar Ambon had gebracht ${ }^{3}$, en mede naar Banda schijnt gegaan te zijn. Den $20^{\mathrm{n}}$ Mei ankerde het weder ter reede van Ambon, "de tijding brengende", teekent 't Hooft in zijn journaal aan, "dat de Resident Berkhoff aldaar was overleden en nog verscheidene Europeaneu, veroorzaakt door de koortsen", die men toeschreef aan de Z.-O.-winden. De Moluksche commissie huurde nu voor Haroekoe het vaartuig in, ten einde "de zich aldaar bevindende kruidnagelen te halen" ${ }^{+}$. De mislukking van de expeditieBeetjes en het bericht der zich uitbreidende onlusten op Haroekoe deden echter aan het vaartuig tevens een minder vreedzame bestemming geven, namelijk tot het deelnemen aau de bestrijding der rebellen, waartegen de gezagvoerder geen bezwaar maakte. Daarna kwam de Britsche kruiser Nautilus, commandant HePBURN, dus een schip van de Britsche O.I.C. te Ambon van Ternate, met

1 Zie bl. 610.

2 Ver Huell, dl. I, bl. 140-141. - Zie ook hiervóór dl. I, bl. 465.

s Zie dl. I, bl. 489 .

- Ver Huell, dl. I, bl. 149. - Verg. hiervóór dl. I, bl. 375. 
bestemming den Britschen resident MACKENZIE naar Bengalen terug te voeren ${ }^{1}$. De Moluksche commissie deed nu bij Mackenzie en Hepburn stappen, ja drong er met de meeste kracht ten slotte op aan, dat ook de Nautilus tot het bedwingen van den opstand zou medewerken, hetgeen de Commissie "te meer" meende te kunnen verwachten, schreef Engelhard in den op bl. 612 vermelden brief van 3 Juni aan Siberg, omdat "de rebellie onder de Engelsche vlag werd gepleegd en voortgezet, en men billijk van de Engelschen zoude hebben" kunnen verwachten, dat zij dit als een smaad, hun vlag aangedaan, zouden opgenomen en gewroken hebben. De Commissie had echter, luidt het in den mallen stijl van Engelhard, "geene redenen van tevreedenheid over gemelde Heer Maquenzie, als glad af geweigerd hebbende" in dergelijke voorstellen te treden. Om niets onbeproefd te laten ter verkrijging van het schip, stelde de Commissie voor: of de Nautilus aan den strijd te doen deelnemen,

$a$. gecommandeerd door zijn eigen officieren en bemand door zijn eigen equipage;

b. gecommandeerd door een Nederlandsch officier en bemand met eigen volk, doch onder waarborg tegen schade;

of den kruiser aan het Nederlandsche gouvernement te verkoopen, terwijl equipage en heer Mackenzie met een van onze schepen naar Batavia zouden gevoerd worden;

óf dat slechts de kruiser zich zou laten gebruiken tot het overvoeren van Commissarissen naar Haroekoe, in welk geval Engelhard zich "derwaards zoude hebben begeven", gelijk hij Siberg schreef, ofschoon het niet heel duidelijk is, waarom hij daarvoor juist de Nautilus noodig had, waar met elk inlandsch vaartuig de overtocht wel gemaakt kon worden.

"Dan deze voorstellen zijn gebleven zonder berigt", m. a. w. Mackenzie antwoordde in het geheel niet meer. "Zelfs de maatregelen van den capitein van de Swalow afkeurende", waren de Engelsche heeren van oordeel, dat „de Capitein zich bij ziju Gouvernement aan eene zware verantwoording had blootgesteld" en dat zijn schip weleens prijsverklaard kon worden, als gestreden hebbende tegen volkeren, waarmede zij "gisteren" nog "verband" hieldeu en die tegen de Engelschen niets kwaads hadden bedreven. "Ik hoop", besloot Engelhard deze uiting van teleurstelling, "dat men op Batavia de heer Maquenzie blijken zal geven van de afkeuring van zijn gedrag."

1 Verg. dl. I, bl. 430, 503-504, 529 en 542. 
C. C. G. G. hebben inderdaad de verregaande dwaasheid gehad zich bij den landvoogd van Bengalen te beklagen over de door Mackenzie en Hepburn aangenomen houding. Daar vond men het niet alleen natuurlijk en terecht, dat de Britsche ondergeschikte ambtenaren niet over 'slands ('s Compagnies) schepen beschikten voor doeleinden, waartoe ze niet bestemd waren, maar de Regeering toonde zich mede in de ernstigste mate vertoornd tegen de Britsche particuliere koopvaarders, die de Moluksche commissie in het bestrijden der opstandelingen van dienst waren geweest. In hoever die toorn niet misplaatst mag heeten, laat ik in het midden; dat echter C. C. G. G. officieel hun ongenoegen te kennen gaven over de quaestie met het landsschip Nautilus, toont, dunkt mij, gelijk in zoo menig ander opzicht, aan, dat zij misten, om een woord van Van Hogendorp te gebruikeu, "slenter" in de behandeling der internationale verhoudingen '.

De voortreffelijke diensten, die de Swallow in de Molukken heeft bewezen onder de moeilijke omstandigheden, waarin het herstelde Nederlandsche gezag zich geplaatst zag, vingen aan met toe te laten, dat daarop ter bestemming naar Haroekoe werden geplaatst de luitenant $\mathrm{t} / \mathrm{z} 2^{\mathrm{e}}$ klasse W. L. VeErman en 4 matrozen van de Nassau; verder werd hem mede gegeven "materieel der artillerie met 2 veldstukken, eenige rolpaarden en eene voldoende hoeveelheid amunitie" 2 . Den $22^{\mathrm{n}}$ zeilde het vartuig de baai van Ambon uit naar Haroekoe; het geeft eeu denkbeeld van de ellende der transporten van de onzen per orembaais in dezen tijd van het jaar, wanneer men weet, dat het schip zulk een onstuimige zee trof, dat het den volgenden dag met gebroken mast de reede van hoofdplats Haroekoe bereikte, hetgeen intusschen Wilson niet weerhield van krachtdadige medewerking te verleenen. "De Swaluw", schreef Engelhard den $29^{n}$ Mei aan Buijskes, "die den 22 van hier naar Haroekoe is vertrokken en den 23 is aangekomen, heeft buitengewoon zwaar weer angetroffen en schoon door het zwaar werken van dat schip in eene kokend zee, dies gronte mast gesprongen is, heeft capitein Wilson, de reyse naar Haroeko nogthans doorgezet, en het bedreigd gevaar van die residentie tegens de invasie van de oproerlingen te Saparoea en aanvallen van de muitelingen onder de volkeren van Hoeroeko zelve voorgekomen. Wij hebben groote diensten van dit schip, waartoe

I Zie Teruggave, bl. 346-352.

2 Van Doren-M., bl. 36. - Ver Huell, dl. I, bl. 141: „twee veldstukken, zes rolparden en de noodige ammunitie". 
de bereidwilligheid van capitein Wilson inzonderheid contribueert."

De staat van Haroekoe zeer dreigend zijnde, werd ook de korvet de Iris derwaarts bestemd. Wij lazen, dat dit vartuig den $21^{\mathrm{n}}$ van Ambon onder zeil ging om de expeditie-Beetjes te steunen, doch het schip de baai nog niet uit was, of het werd wegens de tijding over het mislukken der expeditie teruggeroepen '. Nu moest het schip naar Haroekoe varen, doch de poging om dit eiland te bereiken viel aller ongelukkigst uit. "De corvet Iris", schreef Engelhard in zijn brief uit Ambon van 29 Mei aan Buijskes, "die wegens timmeragie alhier is opgehouden, is den 25 dezer derwaarts vertrokken ${ }^{2}$ en is nog geene tijding van derzelver aankomst aldaar, en wij zijn niet zonder bekommering voor dat vaartuig." Wat er mede gebeurde, lezen wij in de volgende aanteekening in het journaal van 't Hooft te Ambon: "Kwam Z. M. k. m. Corvet de Iris wederom in de baaij; dezelve was bewesten Boeroe gedreven geweest en had niet naar Haroekoe kunnen opwerken."

Inmiddels was naar Haroekoe overgevoerd een detachement van 20 man onder de bevelen van den kapitein der infanterie P. L. vaN Driel en den luitenant Schefrer, waardoor de bezetting van Zeelandia tot 106 man rees. Dappere Van Driel werd er commandant; de flinke adelborst Scheidius kreeg de zorg voor het geschut. Adelborst Musquetier kon de nu komende ernstige dagen niet mede lijden, daar zijn gezondheidstoestand vorderde terugplaatsing op den Evertsen ${ }^{3}$; hij was er den $29^{\text {n }}$ Mei terug ${ }^{4}$.

De ons trouw gebleven radja der negorij Haroekoe werd met eenige Inlanders het binnenland ingezouden, om de geziudheid der bevolking te leeren kennen. Het bleek hoezeer de nederlaag, aan Beetjes toegebracht, overal de gemoederen tegen het gezag had doen opstaan. De rebellen gaven te kenuen, dat zij eerstdaags die "witte varkens" wel anders zouden leeren praten; onze kondschappers ontwaarden ook, dat het getal muiters met den dag aangroeide, en er alleen op een gunstige gelegenheid gewacht werd, om Zeelandia aan te vallen ${ }^{5}$.

1 Verg. bl. 598.

${ }^{2}$ Ook in een nog te vermelden brief van Engelhard aan Van der Capellen leest men als datum van vertrek $25 \mathrm{Mei}$; er stond echter hier eerst 23, doch dit werd veranderd. Daarentegen leest men 23 Mei in den op bl. 612 vermelden brief van Engelhard aan Siberg, gedagteekend 3 Juni. In het journaal-'t Hooft wordt enkel van een vertrek op 21 Mei gewag gemaakt voor de expeditie-Beetjes.

s Ver Huell, dl. I, bl. 141.

4 Journaal-'t Hooft.

${ }_{5}^{5} \mathrm{Als}$ in de beide vorige noten. 
Het waren ook geen ijdele woorden. De eerste verzamelplaats op Haroekoe schijnt geweest te zijn de negorij Hoelalioe ${ }^{1}$. Immers "had het hoofd des opstands eene expeditie van meer dan duizeud koppen naar Haroeko gezonden, ouder bevel van de kapiteins Lucas Selano, Aron en Patti Saba, om de sterkte aldaar aan te vallen en te vermeesteren. En om aan deze hoofden moed in te boezemeu, gaf Matulesia aan eerst gemelde zijnen degen, om die gedurende de expeditie te gebruiken" ${ }^{2}$. Van Hoelalioe waren de muiters getrokken langs de noordkust naar Pelaoe en van daar naar de westkust, naar Kabaoe, "slechts één uur gaans van de negorij Haroeka afgelegen" 3.

De resident Uijtenbroek was afwezig, het gezag alzoo uitsluitend in handen van kapitein Van Driel ${ }^{4}$. Heeft men uit het hiervoren medegedeelde kunnen opmaken, dat feitelijk de Resident er van door was gegaan, Ver Huell, de zwakte der versterking beschrijvende, deelt mede 5: "Ook had de toenmalige Resident, de Heer vaN UtTenbroek, voormaals Chirurgijn in dienst der O. I. Compaguie, zulks in tijds voorzien, en was naar Amboina overgestoken, latende de regering des eilands in handen van den Kapitein van DrIel, ten einde in persoon bij de hooge Autoriteiten aan te dringen op meer versterking."

De muitelingen, in de nabijheid van de hoofdplaats gekomen zijude, lieten zich niet lang wachten: de eerste aanval vond plaats op den $30^{\mathrm{n}}$ Mei. 't Hooft in zijn te Ambon gehouden jouruaal teekent aan :

Ad. 25 Mei: "Er kwam een brief van den luitenant Musquetier, dat de vijand naar Haroekoe oprukte"; en

Ad 31 Mei: "Ontvingen een brief van den Luit. ter zee Veerman, geschreven aan boord van de Zwaluw, liggende voor Haroeko, dat de oproerlingeu den $30^{\text {ste }}$ dezer des namiddags op 3 diverse punten ten 2 uur eene attaque op de bezetting hadden gewagd met circa 700 man; waarvan verscheidene met geweeren gewapend, dog door het beleid en moed van den kapt. van Driel werden zij tot drie malen dapper afgeslagen. De Zwaluw vuurde mede wakker onder hun met het geschut, voornamentlijk in hunue retraite; van onze kant ver-

I Ver Huell, dl. I, bl. 142 noemt deze plaats "Halileo"; zie overigens voor deze en de nader te noemen negorijen hiervóór dl. I, bl. 467 v.v.

2 Van Doren-M., bl. 34-35.

3 Ver Huell, dl. I, bl. 142. Hun tocht langs noord-en westkust werd bepaald door de bestaande wegen.

4 Verg. dl. I, bl. 371-373.

5 Ver Huell, dl. I, bl. 213. 
loren wij twee inlandsche soldaten; de matroos Warman was nog vermist en de matroos de Welt was sterk door het kruit in het aangezigt verbrand."

Adelborst Scheidius verhaalde van dezen aanval, naar Ver Huell's Herinneringen 1 :

"De muitelingen.. waagden den $30^{\text {sten }}$ Mei 1817 met eene magt van circa 600 koppen een aanval, des namiddags ten 3 ure; doch de bezetting steeds onder de wapens zijnde, en ouafgebroken bij het geschut gereed stanude, merkten de Indianen, dat zij niet verrassender wijze kwamen, en dat hun levendig musketvuur dadelijk beantwoord werd. Alhoewel zij door het schrootvuur der veldstukken veel volks verloren, bleven zij evenwel een groot uur lang hardnekkig doorstrijden. Twee manschappen van de bezetting gerakten ongelukkig in hunne hauden, en werden dadelijk ellendig om het leven gebragt. Ziende, dat zij niets tegen onze wakkere krijgslieden konden uitrigten, trokken zij terug.

"De bevelhebber der sterkte en de adelborst Scheidius deden met een detachement de ronde in den omtrek en makten den toegang door het leggeu van roetangels en meer verschansingen moeijelijker, terwijl alles weder tot het afslaan van eenen nieuwen aauval werd in gereedheid gebragt."

De aauval werd gevolgd door een op den $3^{\text {n }}$ Juni, doch ook deze kwam gelukkig niet ouvoorbereid. Scheidius deelde er het onderstaande over mede, na het verhaal over het gebeurde op den $30^{\text {n }}$ Mei ${ }^{2}$ :

"Des anderen daags werd door de waakzaamheid der bezetting een Indiaan gegrepen, Adriaan Radjawan genaamd, welke de gelegenheid der sterkte zocht op te nemen. Deze bespieder werd, door het bedreigen van pijniging, eindelijk genoodzaakt gewigtige mededeelingen te geven, welke hij in den beginue hardnekkig weigerde. De muitelingen hadden het plan gemaakt, om, den $2^{\text {den }}$ Junij, tusschen 12 en 3 ure des namiddags, met eene legermagt van tweeduizeud man andermaal de sterkte aan te vallen, en dat wel, op het geven van een bepaald sein, op vijf punten te gelijk. Deze legermagt bestond gedeeltelijk uit Ceramsche Alfoeren, of zoogenaamde koppesnellers, Honimoaëzen en Haroekaërs, gewapend met geweren, pieken, klewangs, pijl en bogen. Deze zoo zeer belangrijke ontdekking werd dadelijk ter kennisse van den Gouverneur van

1 Ver Huell, dl. I, bl. 142.

2 Ver Huell, dl. I, bl. 142-144. 
Middelkoop gebragt met het verzoek, om, indien mogelijk, nog eenige versterking te bekomen. Ook dit werd toegestaan, zoodat de bezetting vau Zelandia nu tot 200 koppen was aangegroeid.

"Deze bespieder werd aan boord van de Zwaluw gebragt, om naar Amboina getransporteerd te worden.

"Alles werd met den meesten ijver in gereedheid gebragt, om deze geduchte overmagt te ontvangen. De bezetting gunde zich haast geene nachtrust, eu geraakte, bij het gebruik van weinig en slecht voedsel, zeer afgemat. Met deze ingespannen verwachting liep de dag van den $2^{\text {den }}$ Junij zeer vreedzaam ten einde. Doch den volgenden echter, onder het aauheffen van een verward gehuil en getier, rukte de vijandelijke legermagt op onderscheidene punten doldriftig aan. Op een gegeven teeken op de trom vloog ieder op zijn post, en een levendig vuur opende zich van weêrszijde. De voorvechters, in eeneu halven kring rondom de sterkte, dansten den Tjakileli of krijgsdans, met hunne klewangs schermende en de hareu in lange vlechten om de hoofden zwierende, zoo nabij de monding der stukken, dat het schrootvuur een verschrikkelijk bloedbad onder hen aanrigtte. Het is grootelijks te verwonderen, dat zij met zulk eene geduchte overmagt geenen storm wagden, en de bezetting door het groot aantal als het ware overstroomden; dan ware het gedaan geweest met onze dapperen. God verhoedde zulks. Drie uren lang duurde de strijd met onafgebrokene hevigheid. De muitelingen trokken toen af naar het gebergte. De overwinning was met Gods bijstand behald, al hoewel de kaus zeer hagchelijk gestaan had. De Kapitein van Driel en de Adelborst Scheidius deden de ronde, en vonden, zoover zij zich durfden verwijderen, den grond van bloed doorweekt, zoodat het verlies vau de andere zijde aanmerkelijk moet geweest zijn.

"De bezetting begaf zich nu dood afgemat ter ruste; terwijl alles zoo spoedig mogelijk weder gereed gemakt werd voor eene goede verdediging. Alhoewel onze dappere krijgslieden haakten, om den vijand op te zoeken, werd zulks evenwel niet raadzaam geoordeeld, uit aanmerking van onze in vergelijking zoo geringe magt. Een paar dagen vlogen om, zonder dat er iets voorviel, behalve eenige kleine schermutselingen, welke geene melding verdienen."

Over dezen aanval op 3 Juni, teekende 't Hooft te Ambon in zijn jouruaal ad 4 Juni het volgende aan:

"Er kwam een brief van den luit. Veerman van den $3^{\text {den }}$ dezer van boord de Zwaluw, voor Haroeka gelegen, geschreven, welke ons 
mededeelde, dat de rebellen dien zelfden dag om $9 \frac{1}{2}$ uur geataqueerd hadden op 3 diverse punten, dat het gevegt tot $\frac{1}{2} 12$ uur duurde en deu vijand alstoeu met groot verlies langs alle wegen vlugte; men had onder hen een persoon met twee epouletten ontwaard, welke men veronderstelde van deu majoor Beetjes te zullen ziju. Ook hadden zij aan de Noordzijde der rhede van Haroeko een Engelsche vlag waaijen, denklijk om de Zwaluw, hetwelk een Éngels ingehuurd transportschip is, te winnen, maar dit had den kapt. Wilson van dien bodem niet belet om gedurende het gevegt de hollandsche vlag te doen waaijen en onder hun met schroot te vuuren; wij hadden geen verlies ann onze zijde, als een matroos van Z. M. schip Nassau, die in de dij gekwest wird; de wegen waren overal met bloed bevlekt als ook de muren en bamboese heiningen, zodat wel koude zien de vijand aanmerkelijk geleden had."

Engelhard had den 28 Mei 1817 een brief aan Elout gedagteekend, die nog niet afgesloten was, toen hem het bericht gewerd over den geslaagden afweer op Haroekoe van den $3^{n}$ Juni. De brief aan den Commissaris-Generaal hield in, dat, door geldnood er toe verplicht, wissels waren getrokken, die hij verzocht dat gehonoreerd zouden worden ${ }^{1}$; vervolgens komt hij op de uitgebroken onlusten, waarvan de Moluksche commissie eerst d.d. 2 Juni officieel tijding had gezonden ${ }^{2}$, en eindelijk kon hij den $4^{\mathrm{n}}$ nog vervolgen met het bericht der handhaving van het gezag te Haroekoe. Naar aanleiding van deze gebeurtenissen lezen wij dan het navolgende:

De berichten bij officieele briev voorkomende, betreffende de staat van zaken te Saparoea, zullen Uwe Excellentie, zo als ligtelijk te bezeffen is, ten hoogsten ongevallig zijn. Het is te hoopen dat deze onlusten op den eene of andere manier, in derzelver voortgang worden gestuit. De bij officieele briev opgegevene oorzaken dewelke daartoe aanleiding zouden hebben gegeven, zijn niet alle $\ldots{ }^{3}$ er moeten nog andere weezen waarmeede men niet algemeen bekend is, evenwel zich door den tijt wel zullen ontwikkelen - want het kwaad en onvergenoegdheid is te algemeen, en bepaald zich niet alleen tot de volkeren te Saparoea.

Deze gebeurtenissen heeft mij het carracter van de volkeren in de Molukkos leeren kennen: en ik ben in mijne beoordeeling geenzintz te extravagant, met te verklaren, geene natie te kennen, die meer geneigd is, om in massa op te staan, en hunne geburen

1 Verg. dl. I, bl. 402 en 568.

2 De resumtie van dit schrijven in Brieven-V.d. Graaff, dl. I, bl. 43-44.

${ }^{3}$ In het door mij gebruikte afschrift, is een woord weggelaten. 
door vrees, algemeen in dezelve aandeel te doen neemen als deze landaart. Saparoea weegens dies welgeleegenheid en bijzondere voordeelen, van niet in alle jaargetije bevaren te kunnen worden ${ }^{1}$. Onder alle de Besturen hebben deze volkeren zich oproerig gedragen, en zelvs in I8I 2 is de Engelsche Resident aldaar meede op eene cruelle wijze vermoord geworden. Ik heb op Java door millitaire operatien en minnelijke schikkingen, onderscheidene gedugte volksoplopen gestild en weeten te bevredigen. Dan alle te samen genomen, hebben zoo veel hoofdbreken en het neemen van maatregelen niet veryscht, als het oproer te Saparoea nu reeds is komen te vorderen, ofschoon ook aan de andere zeide gebrek aan magt en het ongunstig jaargetij in de nadeelen medewerkt, om de zaak moeijelijk te maken.

Hoe het met de Resident van den Berg, vrouw en kinderen, mitsgaders bezettelingen is afgeloopen, is niets hoegenaamd van bekend; volgens loopende gerugten zouden allen vermoord zijn. De Heemel geeve de berigten van daer gunstiger mogen zijn. Onder de muytelingen, en wel hoofdaanvoerderen, bevinden zich drie burgers, de gebroeders Rabeck, wiens vader op Ambon tegenwoordig is ${ }^{2}$. Wij hebben de oude Man g'animeert, om naar Saparoea over te steeken, en de correspondentie tusschen vader en zoon te openen. Van dit expidient hebben wij alle hoope te verwagten van een goed succes, namelijk om die volksoploop te stuiten en tot hunne plichten terug te brengen.

Deze gebeurtenissen kan Uwe Excellentie zich ligtelijk voorstellen de werkzaamheden van Commissarissen zeer hinderlijk is en agteruitzet: Gelukkig dat de zaaken met het Britsche Gouvernement afgeloopen zijn en daaraan geen hinder is toegebragt geworden.

Dezelve morgen, dat de Britschen Gouverneur van hier vertrok, zijn de berigten van de opstand te Saparoea alhier ingeloopen ${ }^{3}$. Wij hebben daarover met ZijnEd.Gestr. gesproken, - Hoogstdenzelven scheen daar over zeer verwondert te zijn en konde zich geen begrip formeren wat daarvan de oorzaak konde zijn.

De dood van den Bandas Resident Berkhoff is voor het Gouvernement een groot verlies. Den overleedene heeft de korte tijt van zijn bestuur aldaar, alle blijken gegeven, van een actif en eerlijk Dienaar, die tot in de laatste momenten van zijn leeven, eene wezentlijke zucht getoont heeft, de belangen van het Gouvernement met erken telijkheid toegedaan te zijn en van wien

1 De zin loopt niet en vermoedelijk wordt iets anders bedoeld, dan hier staat.

2 Rhébok? Verg. bl. 587.

${ }^{3}$ Den dag te voren: verg. bl. 594 , noot 1 .

"Door een scheur in het papier blijkt niet, wat eigenlijk vóór het "telijkheid" moet staan. 
men alle verwagting konde hebben, $\mathrm{Hij}$ etablisseren zoude een getrouw, rechtveerdig en billijk Bestuur. Zijn verlies is uit de dienaren alhier niet te herstellen. Indien de Resident van Saparoea nog in leven is, zouden de plaatsing van de Heer Neys in de Residentie Banda, en de Heer van den Berg te Ternaten het eenige middel zijn om daarinne te voorzien.

Schoon deze briev op den 28 is ingesteld, heb ik dezelve onafgesloten laten leggen tot heeden, schrijvende den 4 Juny dat ik deze vervolge. De muitelingen hebben de stoutheid gehad, den 30 passato des middags twee uren eene attaque te doen op het Fort te Haroeko, dog zijn manmoedig afgeslagen met verlies vain vele dooden en een aantal gekwesten. Men zoude hebben mogen hopen zij de moed zoude hebben laten zinken, dan zulks schijnt bij dit gespuis het geval niet te zijn naerdien zij op gisteren op nieuw een attacque op het Fort van Haroeko gedaan hebben, van klokke 9 tot circa I 2 uren dog met verlies van een aantal dooden en gekwetsten zijn terug geslagen. De muitelingen zijn gewapend met klewangs, assagaien en pieken en plus minus een hondert geweeren. Aan onze zeide is een Europees van het schip Nassau gekwetst door een musquet schọt.

Gisferen avond vleijde wij ons met de aankomst van het fregat Maria Reygersbergen, dog tot elv uren wierd het bevonden te zijn de Welherby met een ontzet van.... coyangs rijst, dat zo onverwagt als aangenaam is. De Capitein van deze bodem is te Boero aan geweest, alwaar hij heeft vernomen, het stranden op de hoogte van.... van de g'armeerde Brik de Javaan. 1

Het doet Commissarissen leed, dat hun plan met het afzenden van een linieschip naar Java, beladen met specerijen, verijdelt word door de evenementen die thans plaats vinden, en die zulks ondoenlijk maaken. De liniescheepen leggen in deze haven, en het grootste gedeelte van matrosen zijn gedetacheert naer Haroeko, Hilla, de Pas en andere plaatsen, tot dekking van deze Cust tegens de invasie der muitelingen. Commissarissen moeten dus van hunne goede voorneemens, om Batavia met een goede quantiteit specerijen te voorzien afzien, en eene andere gunstige gelegenheid afwagten.

1. Waar in deze alinea stippels staan, is het M. S. onleesbaar; maar in den brief van 20 Mei door Engelhard aan zijn "broeder" geschreven, leest men over deze beide schepen: „Van de schepen tot onze expeditie gehorende, manqueren nog het Engelsche schip Wilherby, beladen met 440 coyangs rijst, dat een heẹl gemis is voor de Molukkos en de g'armeerde brik Java." 't Hooft teekent in zijn journaal aan ad 4 Junî: ${ }_{n} \mathrm{Om} 2$ uur kwam het pinkschip the Willeby binnen van Pasoeroean met rijst geladen." Verg. dl. I, bl. 517-518, zoomede bl. 541 . 
Na den aanval op den $3^{\text {n }}$ Juni lieten de rebellen 'n 6-tal dagen de versterking met rust, toen den $10^{\text {n }}$ Juni te Ambon een brief van Veerman werd ontvangen, meldende, staat in 't Hooft's journaal: "dat den $9^{\text {de }}$ de vijand andermalen een aanval gedaan had op Haroeko, dog wederom door den $k \mathrm{kpt}^{\mathrm{n}}$ van Driel afgeslagen was met veel verlies". - Den $14^{\text {en }}$ Juni had er weder een ernstige aanval plaats. Destijds was Ver Huell's berichtgever Scheidius naar de Nassau teruggeplaatst "om de zaken van wijlen zijnen braven broeder over te nemen" ', zoodat nu Ver Huell ziju herinneringen opteekende uit hetgeen luitenant Veerman van de Zwaluw hem had medegedeeld, alzoo berichtende ${ }^{2}$ :

"dat de opstandelingen den $14^{\text {den }} \mathrm{Junij}$ met eene groote overmagt de bezetting, op drie punten te gelijk, hadden aangevallen, en dat het gevecht van des morgens vroeg tot twaalf ure geduurd had, als wanneer de vijand overal met een groot verlies werd teruggeslagen. De aanvoerder der Indianen was met twee gouden epauletten versierd geweest.

"Opmerkelijk was heţ, dat bij deze gelegenheid eene Engelsche vlag op een der uitstekende hoeken van het eiland woei, doch het Britsche schip de Zwaluw had, gedurende den strijd, de Nederlandsche vlag geheschen en met schroot en kogels op de rebellen gevuurd ${ }^{3}$.

"Steeds gingen de vermetele Indianen voort met de voorposten te verontrusten. Gedurenden den nacht zelfs hadden de patrouilles de voetangels, rondom de sterkte gelegd, met bloed bedekt gevonden, en in het bosch, de nog warme lijken van drie vrouwen en een kind, welke aldaar door de muitelingen de hoofden afgeslagen waren. Waarom deze ongelukkigen slagtoffers hunner bloeddorstigheid geworden wareu, wist men niet te gissen. Zij schenen evenwel deze bloedige daad verrigt te hebben in de nabijheid der sterkte, om er ous getuigen van te maken."

Volgens Engelhard bestond destijds de bezetting uit 300 hoofden, waaronder 70 burgers van Ambou, "die zich bijzonders distingeren, en bereids onderscheidene vitvallen op de vijand hebben gedaan" 4 .

I Ver Huell, dl. I, bl. 145. - Verg. bl. 621-622.

2 Ver Huell, dl. I, bl. 149.

${ }^{3}$ Niet uitsluitend bij deze gelegenheid had de Engelsche vlag gewaaid: zie bl. 647 .

4 Engelhard in den op bl. 654 te noemen brief aan Kruijthoff, aangevangen den $9^{\text {n }}$ Juni, vervolgd den $19^{n}$ Juni. Hij gewaagt daarin van "vier attaques", "seedert dat ik deze heb afgebroken" "met verlies van een aantal dooden en onderscheidene gekwetsten afgeslagen". 
Na den aanval op den $15^{\mathrm{n}}$, "eenige dagen later" 1 , bood zich bij Van Driel het dorpshoofd van Aboro aan ${ }^{2}$, met name Ferdinando, voor een bezoek aan het opstandige Oma, hetzij "om met de hoofden der opstandelingen in ouderhandeling te treden" 3 , hetzij "ten einde de ingezetenen tot rede en onderwerping te brengen" 4 . De man was bij de 70 jaar en leende zich tot deze gevaarlijke zending uit verknochtheid aan het Gouvernement, dat hij te voren zoo vele jaren gediend had 5 . Te zwak om te loopen, werd hij op een stoel naar Oma gedragen "met een witte vlag en eenig gevolg". "Men outving hem", deelt Ver Huell mede ${ }^{6}$, "met alle uiterlijke teekenen van vriendschap en welwillendheid. Onder het toedienen van ververschingen, duurde de onderhandeling eenen geruimen tijd. Toen de muitelingen den ongelukkigen Vorst genoeg hadden uitgehoord, werd hij onverhoeds aangegrepen en hem benevens zijn gevolg dadelijk de hoofden afgeslagen. Vier Indianen van zijn gevolg hadden het geluk van te ontsnappen, en bragten van deze verraderlijke en bloedige daad het berigt aan de bezetting" ?. Misschien als een wraakoefening hierover werd toen Oma met den grond door de onzen gelijk gemaakt. "De Amboinesche burgers, door een detachement militairen ondersteund, deden daarna een aanval op het oproerige Oma, hetgeen in zooverre gelukte, dat de geheele negeri verwoest werd. Daar de ingezetenen reeds bij de aankomst der onzen gevlugt waren, werden niet meer dan vijf van de muitelingen gevangen gemaakt" 8 .

Ook Kabaoe en Rohomoni ${ }^{9}$ kregen in deze dagen een geduchte

1 Ver Huell, dl. I, bl. 150.

9 Voor deze en volgende negorij-namen, zie dl. I, bl. 466 v. v.

8 Ver Huell, dl. I, bl. 150. Ik gewaag op bl. 567 van Fernandus: in hoever wij hier aan denzelfden persoon hebben te denken, weet ik niet.

4 Tïdschr.-Indië, bl. 343.

5 Als de vorige noot.

0 Als noot 4 .

7 „Maar ook deze oude inlander, benevens een bode van Haroekoe en zes personen van zijn gevolg, werden door de muitelingen op eene verraderlijke wijze om het leven gebragt." Als noot 4. Blijkens het journaal-'t Hooft werd het bericht van deze geschiedenis te Ambon bekend den $16^{\mathrm{n}}$ Juni, zoodat het „eenige dagen later" van Ver Huell niet anders kan geweest zijn dan den $15^{\mathrm{n}}$ m. a. w. één dag later.

8 Als noot 4. - Het bericht er van kwam den $18^{\mathrm{a}}$ te Ambon. Op dien dag teekent toch 't Hooft in' zijn journaal aan: ${ }_{n}$ Zond den kapt. van Driel een detachement van Amboynesche burgers, welke de negorij Oma gedeeltelijk verbrandde."

9 Zie over deze plaatsen dl. I, bl. 467. 
afstraffing. Derwaarts was gezeild de eindelijk Haroekoe bereikt hebbende Iris, die den $15^{\mathrm{n}}$ Juni met behulp van 90 gewapende burgers van Ambon, beide negorijen in de ascb legde '. Strijd had men er niet gehad, daar al de ingezetenen bij het naderen van de Iris boschwaarts bleken gevlucht, zoodat geen meusch in de negorijen werd angetroffen, toeu de ouzen er zich vertoonden ${ }^{2}$.

Dat Thomas Matulesi over het gemis aan succes op Haroekoe slecht te spreken was, laat zich verwachten. Hij schijnt zijn teleurstelling geuit te hebben door de boden der ongunstige berichten te schoppen en uit te schelden. Ziehier althans, wat men er over leest in het rapport-Porto ${ }^{3}$ :

Den $22^{\mathrm{n}}$ Mei, des namiddags omstreeks 4 uur, kwamen patih Hoelalioe, patih Aboro, de meester van Hoelalioe, die van Aboro en die van Wasoe te Haria op last van Th. Matulesi, die hen sloeg, trapte en uitschold.

Den $26^{\mathrm{n}}$ kwamen $5^{8}$ menschen van Kamarian' te Haria en ontvingen van Thomas Matulesi den last om aan den strijd op Haroekoe deel te nemen.

Den $27^{\mathrm{n}}$ des morgens omstreeks Io uur verzamelden zich menschen van Iha, Latu, Huwaloi en Amahei te Haria, om op Haroekoe te gaan vechten en des namiddags omstreeks . 3 uur kwamen radja Iha, patih Latu, orang kaja Sepai en orang kaja's van twee negorijen in de Elpapoetihbaai te Haria, om aan den strijd op Haroekoe deel te nemen met ruim Ioo menschen. Des namiddags om 5 uur kwamen radja Pelaoe, patih Hoelalioe en orang kaja Kaibobo te Haria op last van Thomas Matulesi, die hen sloeg, trapte en uitschold. Daarna liet hij ze omringen door de menschen van Haria om op hen te schieten ${ }^{5}$.

Den $3 \mathrm{I}^{\mathrm{n}}$ kwamen menschen van Noesa Laoet te Haria; Thomas Matulesi koos er 80 uit om aan den strijd op Haroekoe deel te nemen. Den $4^{\mathrm{n}}$ Juni omstreeks 6 ure des morgens bracht kapitein Nolot drie gewonden van Haroekoe, een (man) van Titawai, een van Aboeboe en een van Amet. Ten Io ure verzamelden zich de

1 't Hooft teekende hierover in zijn journaal ad 15 Juni aan: „Werden geinformeerd, dat Z. M. corvet Iris op Haroeko was gearriveerd, dat gemelde corvet op de hoek van Cajelolo de negorijen Rohomini en Kabouw verbrand had."

2 Tïdschr.-Indië, bl. 343.

s Dit volgt onmiddellijk op de aanhaling van bl. 625-626.

${ }^{4}$ Deze en volgende namen zijn mij vreemd, althans gedeeltelijk. 't Zijn plaatsen op Ceram.

${ }^{5}$ Het blijkt dus niet, dat er geschoten is geworden. 
menschen van het eiland te Haria; daaruit koos Thomas Matulesi 80 man om mee te strijden op Haroekoe.

Den $5^{\mathrm{n}}$ (Juni) omstreeks ten 12 ure des middags bracht kapitein Nolot van Haroekoe, patih Aboro, patih Wasoe, radja Pelaoe, orang kaja Kaibobo, orang kaja Rohomoni, te Haria, het bericht, dat de menschen van Haroekoe en Samet hadden onderhandeld. Toen sloeg en schopte Thomas Matulesi die hoofden en schold ze uit....

Den $9^{\mathrm{n}}$ des avonds omstreeks 7 uur kwamen menschen van Hoelalioe een man van Siri Sori brengen, die gesneuveld was, ten gevolge van een schotwond en om twaalf uur werd er weer iemand van Siri Sori gebracht, die gewond was.

Den IO $^{\text {n }}$ brachten menschen van Aboro een man van daar om aan Thomas Matulesi te laten zien, dat hij te Haroekoe gewond was.

Den $16^{\text {n }}$ Juni des avonds omstreeks 9 uur brachten menschen van Hoelalioe den radja van Oma, den meester van Oma, vijf menschen van Haroekoe en een jongen ${ }^{2}$. Zij deelden mede, dat de oude radja Aboro van Haroekoe zich wilde onderwerpen, maar dat de vijand was gekomen en dien Radja had doodgeschoten ${ }^{3}$. Thomas Matulesi trapte die vijf menschen en sloeg ze met de parang en vele menschen van Haria kwamen hen slaan en stooten met de kolven van de geweren en uitschelden, maar dien jongen plaatsten zij op een graf midden in het kerkhof en steenigden hem dood. $\mathrm{Zij}$ brachten het lijk naar Saparoea, hieuwen er het hoofd af en brachten dat naar Molano.

Den $18^{n}$ (Juni) ongeveer des middags om 12 uur, brachten menschen van Aboro een vredesbrief- naar het gemeentehuis te Haria en reikten dien over aan Thomas Matulesi. Deze gooide den brief op den grond en zeide tot de menschen van Aboro: breng dien brief terug aan den afzender. Den $2 \mathrm{O}^{\mathrm{n}}$ des namiddags ten 3 ure was ik ziek en toen kwam Harmanus Latuperissa mij vertellen, dat menschen van Lataw en Iha een orembaai van orang Batulomij(?) hadden opgebragt, waarin veel brieven. Thomas Matulesi had die brieven gedeeltelijk verbrand, gedeeltelijk verscheurd.

Misschien ten gevolge van de ziekte des stellers ontstaat er nu in het rapport een hiaat van een maand, gelijk ik reeds vermeldde ${ }^{4}$. De brieven, waarvan het slot onzer aanhaling gewaagt, behooren

\footnotetext{
1 Hier volgen twee onbeduidende zinsneden over Hitoe.

2 "Budakh": kan dus ook slaaf zijn.

3 Dit is al een zeer onduidelijke voorstelling van het gebeurde.

4 Op bl. 579.
} 
vermoedelijk tot de talrijke stukken, die onze autoriteiten niet nalieten te verspreiden, om de menschen te verzoeken tot rust terug te k eeren.

Engelhard had den $9^{\text {n }}$ Juni een brief aangevangen, bestemd voor Tielenius Kruijthoff, gouverneur van Makasser; het schrijven hield hij aan tot den $19^{\mathrm{n}}$ Juni, toen mede kon gemeld worden wat nader was gebeurd op het eiland Haroekoe. In dien brief vinden wij het kenschetsend denkbeeld geopperd om de bevolking maar uitteroeien. In een opwelling behoort men niet al te ernstig de menschen te nemen, maar Engelhard beredeneert niet alleen deze schoone politiek, doch hij schrijft er ook anderen over: nu eens aan den heer Van der Capellen, dan weder aan Mr. Elout; want deze scribent roert voor en na zijn pen in de ongerustheid over hetgeen men wel van hem, in verband met de uitgebrokeu onlusten, zal denken. Ziehier het aan Kruijthoff op den $19^{\text {n }}$ geschrevene :

Van Saparoea verneemt men niets. Volgens een lopend gerugt zoude de Resident van den Berg met vrouw, kinderen en Europesche bezetting geheel uitgemoord zijn. De muitelingen schijnen de dood gesworen te hebben aan alle Europeesen en die op hun zeide zijn getrouw blijven. De Radja van Porto en van Amet zijn beide omgebragt, omdat zij de Resident van den Berg geborgen hebben, en door de binnenlanden naar de Residentie hebben geconduiseert, volgens berigten van een Said, die den I $5^{\circ}$ Mey des avonds van Saparoea was vertrokken, terwijl de Resident met de burgers bezig was de goederen uit de Residentie naar het Fort te transporteeren '. De Radja van Sorry Sorry, een der waardigste Regenten, is in de expeditie omgekomen. Hij was te Amboina toen de opstand uitbrak, en was met de Majoor Beetjes te gelijk van hier vertrokken 2. Te Haroekoe hebben de muitelingen de oud Radja van Aboro schandelijk vermoord. Deze als een man van 70 jaren, had zig aangeboden zich met een witte vlag naar de negorij Oma, die in oproer was, te begeven met eene suite van 12 koppen. In de negorij aangekomen zijnde, is hij zeer wel bij de Radja van Oma en de Inlandsche schoolmeester ontfangen. Ook had hij de Radja over te halen zich met hem naar Haroekoe te begeven, om zich aan het Nederlandsche Gouvernement te submitteeren en zoude dan met hem de terugreijze naar Haroekoe aanneemen. Hij hield zich daartoe zeer ge-

1 Op deze geheel andere voorstelling vestigde ik reeds de aandacht hiervóór op bl. 585 , noot 1 .

2 Verg. bl. 566-567. 
zind. Op het punt dat de Radja vertrekken zoude, verwijderde zich de Radja van Oma en de Schoolmeester voor een moment onder pretext zich te willen verkleeden, in welk moment de Radja van Aboro door een gewapende bende werd overvallen en hij met agt van zijn gevolg omgebragt, hebbende zich vier van de zijne met de vlugt gesauveert. Dit is een proefstuk van verraat en kenmerkt de verstoktheid van de booswigten.

Zonder ontzet van drie a vier brikken, is er geen mogelijkheid deze insurgenten tot onderwerping te brengen. En dan zoude de vraag zijn of de voorzigtigheid niet zoude komen te vorderen, de gansche maatschappij van menschen te Saparoea uit te roeijen; er kan maar eene reede weezen, die zulks ontraden doet. Dat is dat als men ze niet gansch verdelgd en dat zij zich verspreiden op de kusten van Ceram en andere eylanden, de Molukkos voor altoos door dat gespuis zal ontrust worden. Ook zal het uitroeijen dit ongelukkig gevolg hebben, dat de nagelen niet zullen kunnen worden ingeoogst door gebrek aan handen en het Gouvernement voor twee derde zoude missen de recolte. Tusschen deze uitersten moet ik thans beslissen. Verdient hebben de Saparouanesen dat voor hen geen de minste consideratie wordt gebruikt, het tegenwoordige geslagt deugd niet. Onderscheidene malen hebben deze volkeren opstand verwekt. In I 8 I 2 hebben zij ook een Engelsch resident deerlijk vermoort als ook te Hilla; en om dus voor altoos daar zekerheid te hebben van rust, zoude ik er voor zijn, al wat bejaard is te rerdelgen en niemand te sparen en dit moet zo voorzigtig worden aangelegt, dat de muitelingen de gelegenheid benomen wordt te ontvlugten.....

Deze fraaie brief, dien ik onmogelijk geheel naar de letter heb kunnen overnemen, omdat hij blijkt te zijn overgeschreven door iemand, die geen Hollandsch kende en het schrift vau Engelhard hem te onduidelijk was - zoodat er soms onzin in staat gaat over in beschouwingen ten aanzien van het verzoek aan Kruijthoff om voor mevrouw Engelhard "beneden- en bovenkousen" te laten maken. "De bovenkoussen kunuen niet te fijn zijn." Het epistel besluit aldus met het oog op zijn vertrek naar Batavia, waarheen hij hunkert om den toorn der goden te bezweren :

"Ik heb een balletje opgeworpen bij de commandanten der oorlogschepen om Macassar aan te doen, doch ik heb geen bijval gevonden en omdat ik UwEdGestr. nu tog gaarne een bezoek wenschte te geven, zal ik trachten met eeu der particuliere Engelsche scheepen naar Batavia te gaan, dan ben ik mijn eigen meester en zal ruim zo plezierig overvaren als met de stijfheid van een Capitein ter zee." 
Het uitroeiingsdenkbeeld niet loslatende, schrijft deze barbaar in zijn brief van 16 Juni 1817 aan Elout: "Indien de Maria Reygersbergen spoedig komt opdagen, zal ik aan de instantie van den overste Pool voldoen en begeven mij in persoon na Haroeko om alles van nabij op te nemen ${ }^{1}$, en de nadere arrangementen te maken om de insurgenten tot onderwerping te brengen door zoodanige middelen als met het belang en de waardigheid van het Gouvernement overeenkomt. Saparoea en Haroeka zijn de plaatsen, waar de meeste nagelen worden ingeoogst; met het uitroeijen van deze geheele Maatschappij van menschen, zoude aan deze cultunr de handen ook gelijk onttrokken zijn en nimmer te herstellen wezen."

En in een brief d.d. 23 Juni 1817 an Elout kwam Engelhard andermaal op zijn extirpatie-denkbeeld:

Volgens het opinie van de meeste Amboinesche Radjas en Orang kayas, die alle blijken geven van getrouwheid aan het Nederlandsche Gouvernement, zoude men geen enkeld mensch op Saparoua moeten sparen, maar het gansche geslagt verdelgen. Er is bij mij geen kwestie of de volkeren van Saparoua, die het oproer begonnen hebben en zich aan zulke grouwelen (schuldig makten ?) als het uitmoorden van eene gansche bezetting, zonder vrouwen of kinderen te sparen, die ook hunne handen geslagen hebben hunne eigene vorstjes of hoofden om te brengen, verdienen

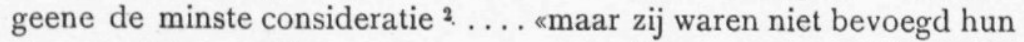
eigen rechter te zijn en een oproer te stigten, waarvan hier geen voorbeeld is. En zulke weezens hebben geen de minste aanspraak op de meeddogenheid van een Gouvernement. Dan het komt mij voor dat een gansche maatschappij van drie à vier duizend weerbare manschappen in eenen uit te roeijen geen werk te zijn van eene dag (bij manier van spreeken) en ook niet zo gemakkelijk zoude gaan, als men zich wel voorsteld, zonder dat het meerder gedeelte, zich met de vlugt sauveert en op Ceram of andere nabij gelegen eilanden zal verspreiden, als wanneer zij voor een tijd lang voor het Gouvernement nadeelig zullen zijn, en niet alleen de Cust alhier ontrustten, maar met de aanhang, die zij overal vinden, de geheele Molukkos beroeren en voor een tijt lang in een roofnest herscheppen zullen. Een andere bedenking van geen minder gewigt, is, dat Haroekoe en Saparoea voor twee

1 Verg. dl. I, bl. 553, alinea 1. Wij zullen zien, dat Engelhard aan dit voornemen geen gevolg gaf.

2. De brief is hier gedeeltelijk afgescheurd; er staat echter in substantie, dat wanneer hun redenen tot ontevredenheid waren gegeven, zij zich tot Commissarissen hadden behooren te wenden. 
derde participeert in de recolte van nagelen en dat met de vernietiging van deze volkplanting, de handen aan die culture zullen worden onttrokken en daarin met geene middelen van hier behoorlijk voorzien kan worden.

Deze overweging brengt de heer Van Middelkoop en mij in een tweestrijd om in deze de beste keuze te doen. Ondertusschen komt het mij voor, dat de volkeren van Haroeku niet gelijk te stellen zijn, met de volkeren van Saparoua. Nadien de Iaatsten zich aan de hoogste misdrijf hebben schuldig gemaakt, en het oproer hebben begonnen en de eerstgemelden door bedreiging daartoe zijn gebragt, hetgeen dan ook altoos in consideratie zal dienen te komen, als men eens tot de rigoureuste middelen om het oproer te dempen zal dienen over te gaan.

Het zal mij aangenaam zijn, dat deze zaak spoedig tot een einde worde gebragt en de gelegenheid dan nog voor mij gunstig zal mogen zijn mij na Ternate en Banda te kunnen begeven: Terwijl in contrarie geval ik genoodzaakt zal zijn, de werkzaamheeden van de Commissie te eindigen en met mijn vrouw na Batavia terug te keren, het $\mathrm{zij}$ met een van de linieschepen of met eene convenabele particuliere scheepsgelegenheid, alzo het verblijf alhier voor mij eene verveling is op de presente voet. Het doet mij leed tot deze verklaaring te moeten komen, omdat ik gevoele, slegts voor een gedeelte aan mijne commissie te hebben voldaan, dat echter aan evenementen en omstandigheeden buiten mijn schuld is te attribueren.

Wat een verregaande geesteloosheid van gedachtengang! Het zijn zoovele brieven als deze, die mij met weerzin tegen den scribent hebben vervuld en mij het artikel over Engelhard in De Indische Gids deden schrijven. Had hijzelf met Beetjes die moeitevolle expeditie naar Saparoea medegemaakt, o dan zou de zaak geheel anders zijn uitgevallen...., meent hij. "Ik kan het mij niet genoeg verwijten", schrijft hij toch zoowaar aan Tielenius Kruijthoff in den brief van den $9^{\mathrm{n}}$ Juni, "dat ik niet dadelijk met de expeditie ben meede gegaan, die dan zeeker stellig gansch anders gedirigeert en uitgevallen zoude ziju." Ja wel zeker stellig! Maar, naar wij lazen, hij zal dat verzuim trachten goed te maken door straks zich te Haroekoe te vertoonen, Hij wilde er echter eerst over spreken met den luitenant-kolonel Kraijenhoff, die intusschen naar Haroekoe op reis was en wiens terugkomst alzoo moest afgewacht worden. Dit doet hem nog aan Elout in zijn brief van 23 Juni schrijven : Wegens het niet komen opdagen van het fregat de Maria Reygersbergen en de vertraging in de ontlossing van het Engelsche schip the Willerby, 
zoude ik besloten hebben over de pas met een klein vaartuig naar Haroekoe te steeken. Dan vermits den Luitenant Collonel en Commandant van de Troupes in de Molukkos Krayenhoff zich zeedert in persoon derwaards heeft begeven om de gesteldheid van Haroekoe op te nemen en te zien of met eenige hoop op succes op eene zo offensieve als deffensieve wijze tegens de muitelingen kan worden geageert, en daarna middelen te beramen met den Commanderend officier van het detachement aldaar en den commandant van de Coloniale corvet Iris om te tragten het oproer door kragt van wapenen te dempen, heb ik geoordeeld beter te zijn deszelvs terugkomst af te wagten om te zien of zijne bevinding en rapporten ook eenig aanleiding zou kunnen geeven tot het neemen van mesures, waarover zich Commissarissen eerst met de anderen zouden dienen te verstaan, beschouwende de afdoening van de zaak met de muitelingen te zijn van het uiterste gewigt voor de toekomende welvaart en belangens van het Gouvernement."

Om welke redenen wordt niet vermeld, maar van Engelhard's tegenwoordigheid op het terrein van de onlusten is nooit iets gekomen, noch ten aauzien van Haroekoe, toen Kraijenhoff van daar terug was, noch ten anuzien van Saparoea, waarheen weldra de Reygersbergen, de Iris en andere schepen zullen gaan. Veel lust om den tocht in een orembaai te maken, schijut hij in ieder geval niet gehad te hebben, want de weigering van Engelsche zijde om de Nautilus naar Haroekoe te doen gaan, is, naar men uit het hiervoren medegedeelde zou besluiten ${ }^{1}$, op het verzetten van het plan in ieder geval van invloed geweest. Overigens meer dan dit geleuter in de tweede helft van Juni hooren wij, gelijk van Hitoe, tot den aanvang van November niets over het beloop der onlusten op. Haroekoe.

Dit was nu de man, die het van landvoogd Daendels onverantwoordelijk heeft gevonden ${ }^{2}$, dat $/$ hij bij incorporatie van ons dierbaar vaderland met Frankrijk de collonie niet vrij en ouaf hankelijk_heeft verklaard, op welk idee hij door mij een en ander malen gebragt is en in de geschrifte kan prouveeren".

1 Zie bl. 641.

2Priangan, dl, I, bl. 87. 


\section{HOOFDSTUK VIII.}

\section{Tuchtiging van landschap Hatawano, noordoostelijk gedeelte van Saparoea: 9-12 Juli.}

\footnotetext{
Bestemming van de Reygersbergen met Iris en Dispatch naar Hatawano. Reis van de Reygersbergen: 4-9 Juli. - Beschieting door de Reygersbergen van Hatawano: 9 Juli. - Nadering van de Iris: 10 Juli. - Hatawano onder kruisvuur genomen door Reygersbergen en Iris: 12 Juli.- Ontevredenheid van commandant Groot op het bestuur te Ambon.
}

Eindelijk, den $25^{\mathrm{n}}$ Juni was de Reygersbergen, kapitein Groor, van Ternate te Ambon teruggekeerd '. Terstond werd het schip bestemd voor een expeditie naar het eiland Saparoea, waartoe zouden medegaan de ons bekende Iris, kapitein Pool, en nog een ander dan de Swallow ingehuurd suelzeilend Engelsch schip: de den $11^{\mathrm{n}}$ Juni met zout en rijst van het Gouvernement uit Batavia aangekomen Dispatch ${ }^{2}$, kapitein CrozIER, ook een vaartuig, dat tot groote ergernis van de Bengaalsche regeering aan de bedwinging van den opstand krachtig heeft medegeholpen. Wat betreft de Iris, het zou weldra blijken, dat, naar het oordeel van den commandant van het oorlogsschip, kapitein Pool van de Koloniale Marine zich niet volgzaam genoeg toonde.

Ter Ambous reede "ten anker liggende", "ontwaarde ik", journaliseerde Groot op den $25^{\mathrm{n}} \mathrm{Juni}$, "de fameuse tijding, omtrent de rebellerie van de eilanden Saparoua, Harouka en een gedeelte van de westzijde van Amboina, alsmede ook den uitslag van den groot(?) ongelukkige expeditie; teffens mondelinge order tot het spoedig klaar maken van het fregat... Ik had met het fregat circa 5 weken reis gehad ... alles moest worden voorzien... gaarne wenschte ik aan de verlangens van spoedig gereed te zijn te voldoen." Den $2^{\mathrm{n}}$ Juli was het schip zeilklaar.

Het doel der expeditie was "om de volken, die deel aan den

1 Zie dl. I, bl. 506.

2 De datum van aankomst in het journaal-'t Hooft. 
opstand genomen hadden, te tuchtigen", leest men bij Van Doren ${ }^{1}$; maar Engelhard schreef in zijn Bataviaasch verslag: "ten einde, overeenkomstig zijne instructie, met de muitelingen in correspondentie te treden". En het een, èn het ander heeft op breede schaal plaats gevonden; commandant Groot zou alzoo niet verantwoordelijk geacht kunnen worden voor door hem bevolen mantregelen, die werkelijk naar niets schijuen te lijken en waarvan men dan de schuld, behalve bij de Moluksche commissie, ook bij den bevelhebber van het Ambonsche eskader, bij Sloterdijk, zou moeten zoeken. Er valt echter nog een ander gezichtspunt te openen, zooals uit bl. 665 zal blijken. Het eerste doel der expeditie werd overigens niet, gelijk men mocht verwachten, de hoofdplaats van het eiland, maar het hiervóór beschreven landschap Hatawano ${ }^{2}$; de redeu van deze oogenschijnlijk vreemde keuze vind ik mede niet vermeld ${ }^{3}$.

Ofschoon den $2^{\text {n }}$ Juli gereed tot vertrek, kon Groot niet onder zeil gaan, daar zijn macht nog door eenige Ambonsche burgers zou versterkt wordeu: "deeze burgers", luidt het jourual, "den volgenden dag volgens zeggen van den Gouverneur gereed zijude, verzogten Commissarissen, dat ik mijn vertrek een dag zoude uitstellen. HunEd. begrepen toen zo wel als ik, dat ik vrij zwak van volk was voorzien, om eene dergelijke groote expeditie te doen." De burgers dangden inderdaad den volgenden dag op, doch eerst "ten 6 uuren s'avonds kwamen 24 gewapende en ten $\frac{1}{2} 9$ uur nog 12 ongewapende burgers aan boord"; de ongewapenden waren bestemd voor pagaaiers op de orembaais. Wij zullen hierna zien, dat onder deze medegenomen Inlanders menschen zijn geweest, die in geenen deele te vertrouwen waren. Eindelijk ging men den $4{ }^{\mathrm{n}}$ onder zeil. Een

1 Van Doren-M, bl, 45-46. De Schrijver zegt de door hem medegedeelde bijzonderheden "gedeeltelijk" ontleend te hebben aan het rapport van commandant Groot d.d. 21 Juli 1817, ingediend aan den chef van het eskader te Ambon, Sloterdijk.

${ }^{2}$ Zie dl. I, bl. 473.

s Boelen deelt mede: „Het plan onzer expeditie was, op den hoek van Hatawana, op de noordzijde van Saparoea, waar zich vijf kampongs of negorijen bevonden, eene landing te doen en te trachten zoodoende eene afleiding te geven aan het leger der muitelingen en ze te verhinderen hunne gezamenlijke macht tegen de hoofdplaats Saparoea te doen optrekken." Boelen.M., bl. 246. Ongetwijfeld is in deze mededeeling een fout, want de hoofdplaats was in handen der rebellen en er ging destijds niet van onze zijde een macht heen om de negorij te hernemen. Het is echter zeker, dat het voornemen eener landing in het landschap Hatawano heeft bestaan, Waaran $_{\text {-gevolg }}$ is gegeven, gelijk wij in hoofdstuk X, bl. 689 , zullen lezen. 
persoon, van wien wij nog veel zullen hooren, was den $2^{\mathrm{n}}$ Juli op de Reygersbergen gekomen. "Daar niemand onzer de wateren om de Specery-eilanden ooit bevaren had, werd ons", verhaalt Boelen ${ }^{1}$, "een loods aan boord gezonden. Die man, Christaan Christiaansen geheeten, was een Deen van geboorte en sedert 40 jaren onafgebroken in de Oost-Indische koloniën rondvarende geweest. Hij was nu oud en leefde rustig in een der kampongs op het eiland Amboina. Ook zond men ons aan boord een 24-tal gewapende Amboineesche burgers én een 12-tal nog ongewapende, met welke wij een orembaai zouden bemannen, die wij op sleeptouw mede nameu." Christiaansen was 67 jaren, volgens Ver Huell 2; deze noemt hem "bijna suf"; in Engelhard's Bataviaasch verslag wordt hij angewezen als "oudluit. $\mathrm{t} / \mathrm{z}$ in vorigen Hollandschen dienst".

Het weder was weinig voorspoedig. Eerst den $9^{\text {n }}$ bereikte men Saparoea's noord-oostkust: Hatawano. "Met den dag", leest men in Groot's journaal, "peilde de zuidhoek van Nousalaut Z. $\frac{1}{2}$ W., lielden af en stuurde op de hoek van Hatowana aan; ten half agt uuren zag ik de Iris in 't westen om de Oost werken; ten 8 uuren had ik de hoek van Hatowana in het Z. W. $\frac{1}{2}$ W.... ten $\frac{1}{2} 11$ uuren de negorij Hatowana op een kabellengte genaderd zijnde.... hield ik om de N.O. hoek heen en vuurde met schroot en kogels op het daar zijnde gewapende volk." Wat er op dien $9^{\text {n }}$ Juli voorviel vindt men echter beter aangeteekend in het journaal van Boelen, waaruit het volgende wordt getrokken ${ }^{3}$ :

"En bevonden ons in de groote Ceramsche bogt Hamahaij genaamd, hielden af en stuurden Z.-W. naar de negorij Hatowana, op het eiland Saparoea 4 .

"Om 10 uur op een kabellengte de wal genadert zijnde, deden wij eenige scherpe kanonschoten op de negorij Hatowana, waarop bij de inwoonders een sterk geschreeuw ontstond; mannen, vrouwen en kinderen zag men vlugten, enkelde mannen kwamen op het strand schreeuwen en dansen, terwijl zij ons, zommige met snaphanen gewapend en anderen met een kleewan, schild en asagaai, al drijgende uitdaagden."

1 Boelen-M., bl. 245-246.

2 Ver Huell, dl. I, bl. 181.

s Verg. Boelen-M., bl. 246, waar echter vergeten is te vermelden den datum van 9 Juli.

4 Misschien is met Hamaha $\ddot{3}$ bedoeld Amahai in het zuiden van de oostkust van de Elpapoetih-baai: zie onze kaart. 
Men ankerde voor Hatawano en Itawaka - zie onze kaart of Hawaka, in Boelen's journaal genoemd Tahawano.

"Deden op de hoek van de negorij Tahawano nog 10 schooten; de Indianen waren veelen derwaarts gevlugt en vertoonden zig opendlijk, terwijl zij niet dagten ons geschut aldaar berijken konde; dog toen onze kogels door hunue bamboezen huizen henen nog verder vlogen, vertoonden zij zig niet meer als agter een zware boom; ook konden wij die negorij niet veel beschadigen, daar dezelve door de dikke boomen en groen geheel onzigtbaar was. In de negorij Hatawano hadden zij inmiddels een steene muur opgeworpen, waaragter zij schuilden; de meesten vluchten echter, wanneer wij vuurden, het dorp uit en slechts een schildwagt konde men gewaar worden, die zig gedurig agter een zeer zware boom verborg."

Het schip lag ten slotte zóó, dat om $12 \frac{1}{2}$ uur men de negorij kon bombardeeren; men eindigde er mede om 1 uur, nadat circa 80 scherpe schoten gedaan waren; sommige op het strand gelegen prauwen en vele huizen werden daardoor sterk beschadigd, "dog wij zagen daarbij, dat men veel kruit en kogels zoude verspillen, voor dat het dorp plat was, daar er vele zware bomen in stonden en de kogels door de houte en bamboezen huizen slechts gaten maakteu. De Indianen deden van de wal verscheidene snaphaanschooten, waarvan de meeste kogels het schip raakten en er zelfs over heen vlogen. De koloniale korvet Iris laveerde intusschen met de barkas op sleeptouw om bij ons te komen ${ }^{1}$. De $\mathrm{kapt}^{\mathrm{n}}$ Groot willende, dat dezelve ten oosten vau de negorij zoude liggen, opdat wij gezamentlijk een kruisvuur zouden maken en zo met schieten meer vijliger tot de landing zouden kunnen zijn, zonden derhalve om $5 \frac{1}{2}$ uur een gewapende orangbaaij met een officier naar het Corvet." 2

"Om $6 \frac{1}{2}$ uur zonden de gewapende groote shaloup met twee draaybassen en een officier, als mede de kleine gewapende orangbaai met een Cadet $1^{\text {ste }}$ klasse om gedureude den nagt te kruissen en de communicatie op Ceram en andere eilanden te beletten."

"Deden gedurende de wagten scherpe schoteu op de negorijen om de vijand te verontrusten.

"Om half twaalf in den nagt deden twee scherpe schoten op de negorij tot sein voor de shaloup en orangbaaij om aan boord te komen. - Om 11 uur kwam de groote orangbaaij met den officier

1 De barkas was een klein tweemast vaartuig, behoorende aan den Fvertsen.

2 Over de schrijfwijze orangbaaij verg. bl. 605, noot 3 . 
van het Corvet terug, die ons meldde de $\mathrm{kap}^{\mathrm{n}}$ Pool gezegde positie zoude innemen, dat hij Europeërs en Ambonezen burgers te zamen nog 70 man onder de wapens koude brengen, welke bij de landing zouden assisteren."

Deze gezamenlijke actie van de Reygersbergen en de Iris kon echter zoo spoedig niet plaats vinden, doordien de korvet er niet in slaagde de daartoe noodige, aangewezen positie in te nemen ${ }^{1}$. Den $10^{\mathrm{n}} \mathrm{Juli}$ ging alzoo zonder bijzondere gebeurtenissen voorbij. "Om 9 uur met parade", leest men in het journaal-Boelen, "schoten de geladen geweren af; men antwoordde ons van de wal met verscheidene geweerschoten, waarvan de meeste kogels over ons heen vlogen."

"De coloniale korvet Iris was wederom ouder zeil en werkte om de oost, dog moest tegen den avond zijne vorige ankerplaats wederom opzoeken.

"Gedureude den dag deden wij van tijd tot tijd enige kanonschoten om de Indianen te verontrusten. Zij kwamen nog somtijds daaronder te voorschein en riepen ons toe mari di darrat."

Ook den $11^{\mathrm{n}}$ Juli slaagde de Iris ten gevolge van het slechte weder er niet in de vereischte positie in te nemen. "Wij deden", schrijft Boelen in zijn journaal, "gedurende den dag nog eenige kanouschoten; de Indianen vuurden met het geweer en hoewel de kogels verscheidene keeren tot over het schip kwamen, zo werd er dog geen mens gekwets."

"In de nademiddag wordt er van het strand geroepen: Komt Hollanders en Amboinesche burgers aan de wal om de presenten te halen, die op $u$ wagten. Brengt de Kapitein mede om de plaats te vervangen van den majoor Beetjes." 2

"Met den avond zetten wij de kleine orangbaai en labberlot in, daar die vaartuigen eenige reparatien behoefden. De Indianen zulks ziende, hieven van alle kanten geschreeuw aan, kwamen al springende met hunne kleewangs zwaaijende ons uitdagen; waarschijnlijk dagten zij, dat wij vertrekken wilden." 3

Des nachts was het, deelt Groot's journaal ad 11 Juli mede, buiig weer geweest, zoodat de sloepen weinig konden verrichten en

1 Volgens Van Doren-M., bl. 46, kreeg Pool last om te ankeren vóór Passo Poetih, een plaats, die ik herhaaldelijk in de scheepsstukken vermeld vind, maar niet kan thuis brengen en ook niet op de kaart van Van Doren is aangegeven; in Groot's journaal staat Passer Poetih.

2 Verg. Ver Huell, dl. I, bl. 173.

s Verg. Boelen-M., bl. 247. 
de geweren zoowel als de patronen nat werden. Aan boord deed de Commandant de posten des nachts verdubbelen. In den ochtend van den $12^{n}$ ging een gewapende orembaai van de Reygersbergen naar de steeds opwerkende Iris, die, ofschoon wel goed bezeild, door het ongunstige weer slechts langzaam naderde. Eerst ten 9 ure in deu ochtend van dezen dag kwam, volgens het journaal-Groot, de Iris in het N.N.O. nabij de Reygersbergen ${ }^{1}$. Nu werd door beide schepen een kruisvuur tegen de opstandige strandbewoners geopend. Een evenement scheen te ziju het raken van een onbeduidend huisje. "Deeden", leest men in het journaal van den $12^{n}$, "een scherfschot op een steene, wagthuisje, dat dadelijk instorte, en warruit eenige negers de vlugt namen." En eenigszins uitvoeriger in Boelen's Memoriaal 2 : "Den $12^{\text {den }}$ Juli eindelijk kwam de korvet Iris in onze nabijheid ten anker en posteerde zich in het $Z$. O. van het fregat, om aldus met de Maria Reigersbergen een behoorlijk kruisvuur op de vijandelijke kampongs te kunnen onderhouden. Van de bramzalings kon men over het aan het strand gelegen bosch een goed eind langs de velden zien en wij bemerkten een huis, waarin zich veel gewapend volk bevond en er uitzag als een soort van hoofdwacht. $\mathrm{Na}$ eene peiling van dat huis van de bramzalings, richtteu wij er een der jagers van de bak op. De kogel daaruit afgeschoten moet bij hen groote verwoesting aangericht en ontsteltenis veroorzaakt hebben, want wij zagen allen eensklaps dat wachthuis ontvluchten en konden daarna duidelijk zien, dat het sedert verlaten bleef." Dit scheen echter ook de eenige vrucht van het bombardement. "Dan het weinige effect gezien hebbende", journaliseerde Groot, "deed ik sein met art. 787: uitscheiden met vuuren." En verder: "De Capt. Luit. Pool aan boord, mij rapporteerende er bij Passer Poetij geen ankergrond was te vinden en daarom naar mij toe was komen werken, om nadere orders af te vragen." Memoriaalhouder Boelen stelt het daarentegen voor, dat Pool bepaaldelijk aan boord van de Reygersbergen was gekomen, om het nutteloos schieten te doen ophouden; immers wij lezen ${ }^{3}$ :

"Nadat de Iris zijne positie genomen had, begonnen de beide schepen de kampongs te beschieten, doch wij bemerkten weldra,

1 De datum van den $12^{\mathrm{n}}$ is ook goed opgegeven bij Van Doren-M, bl. 48.

2 Boelen-M., bl. 247.

s Boelen-M., bl. 248. - Van Doren deelt mede, dat het vuur geen uitwerking op de rebellen had, "daar deze zich hadden teruggetrokken". Van Doren-M., bl. 48 . 
dat er bij dit bombardement niet veel schade aangericht werd. De kogels en het schroot vlogen door de bamboe-woningen heen en lieten ter nauwernood een gat achter in de van gabbe-gabbe gemaakte wanden ${ }^{1}$. De Inlanders waren met vrouwen en kinderen reeds eenige dagen te voren uit de kampongs gevlucht en hadden zich achter door hen opgerichte bentings verborgen. Die verschansingen en bentings werden door hen gewoonlijk des nachts opgericht. Vrouwen en kinderen waren er aan behulpzaam. Zij bestonden in muren van eenige voeten breedte, zoodat ze met 4.8 ponds kogels niet bres geschoten konden worden. De muren waren gemaakt van op één gestapelde klipsteenen en hadden eene inderdaad bewonderenswaardige vastheid en sterkte. ${ }^{2}$

"Gedurende het vuren der schepen kwam de Overste Pool, kommandant van Z. M. korvet Iris aan boord van het fregat en deed het voorstel om dit noodeloos kruit en ammunitie verspillen te staken en te trachten, door minzame onderhandelingen met de bevolking, de vrede met al de negorijen tot stand te brengen, te meer daar de Overste, die onlangs van Haroekoe kwam ${ }^{3}$, daar vernomen had, dat het mishagen en het oproer der Inlanders door de slechte behandeling en de knevelarijen van den Resident veroorzaakt waren.

"Daar onze Overste Groot met deze zienswijze inslemde, werd aan de Iris het sein gegeven ophouden met vuren."

Dit stemt geheel met het journaal-Boelen ad 12 Juli. KapiteinLuitenant Pool was om 10 uur 's morgens aan boord van de Reygersbergen gekomeu, en terwijl hij zich nog daar bevond werd om $10 \frac{1}{2}$ uur naar de Iris geseind het vuur te staken ${ }^{4}$.

Alzoo zou het niet aan de te Ambon gegeven instructie hebben gelegen, dat Groot nu een weg insloeg, die den toets van ernstige critiek niet kon doorstaan en waarlijk belachelijk mocht heeten, indien het niet zoo treurig was. De rebellen verjoegen ons van Saparoea, zij behaalden er een schitterende overwinning op de expeditie-Beetjes, een nieuwe expeditie zeilt naar het eiland, vernielt er zooveel maar mogelijk is en als men dan ziet er niet mede te kunnen vorderen, krijgt men het in het hoofd aan de rebellen te vragen zich te onderwerpen!

Het blijkt overigens, dat Groot schrikkelijk gebeten was op de

1 Gaba-gaba: verg. bl. 562 , noot 5 en bl. 606 .

2 Verg. bl. 625 .

3 Namelijk Pool met de Iris: verg. bl. 652.

4 Ook bij Van Doren-M., bl. 48 deze voorstelling. 
Moluksche commissie, die hem slechts averechtsche inlichtingen had verstrekt en daardoor te geringe middelen om zich tegen de rebellen te doen gelden. "Daar ik duidelijk zag", lezen wij in zijn journaal van dien $12^{\mathrm{n}}$, "dat de Heeren Commiss ${ }^{\mathrm{n}}$ geene lokale kennisse bezaten omtrent de ankerplaatșen bij deeze eilanden, en ik ook gedupeerd was met de macht door HunEd. opgegeven, bevond ik mij niet in staat om aan de van HenEd. ontvangen instructie te voldoen." De ergernis van den Commandant uitte zich nader in zijn rapport d.d. 21 Juli 1817 aan kapitein t/z Sloterdijk. Het geschut van de Reygersbergen was reeds bij het vertrek uit Ambon te zwaar geoordeeld, om er bij een landing mede te ageeren; vandaar de toezegging van veldgeschut, dat nagezonden zou worden, maar niet kwam. ${ }^{1}$ Verder was er gebrek aan brandhout, meel en koffie. Het journaal ad 1 Juli wees mede daarop aanstonds bij de inlading: "Ontvangen het kruit en behoeftens, van de welke het laatste maar gedeeltelijk, als zijnde niet voorhanden... Ontvingen van de Adm. Everts spek en twee vadem brandhout; dit laatste artikel was zeer schaars te bekomen, zodat ik met $12 \mathrm{v}^{\mathrm{dm}}$ ben vertrokken." De Dispatch bracht eerst den $18^{\text {n }}$ Juli kruit aan, maar ook nu niet voldoende, zoodat èn Evertsen èn Iris daaraan steeds "gebrek leden" 2.

1 Verg. hierna bl. 699.

2 Van Doren-M., bl. 60. Verg. hierna bl. 681. 


\section{HOOFDSTUK IX.}

\section{Vergeefsche ouderhandelingen met het landschap Hatawano: 12-21 Juli.}

Groot's aanbieding van vrede: 12-13 Juli. - De besprekingen met de rebellen d. d. 14 Juli op het strand met Ellinghuijsen en Christiaansen. Zending van Christiaansen naar hoofdplaats Saparoea: 14 Juli. - En van Boelen naar Ambon: 14 Juli. - Correspondentie der rebellen met Groot: 15 Juli. - Zending van Feldmann naar hoofdplaats Saparoea: 17 Juli. - Boelen's reis in orembaai naar Haroekoe: 14-15 Juli. - Per prauw van Haroekoe naar Toelehoe: 15 Juli. - Per draagstoel naar Soeli, per prauw naar Bagoeala, te voet over den Pas, per prauw naar hoofdplaats Ambon: 16 Juli. - Verblijf te Ambon: 16-17 Juli. - Terugreis naar Soeli en Toelehoe: $17 \mathrm{Juli}$ - Terugreis naar Haroekoe: $18 \mathrm{Juli}$. - Terugreis per orembaai naar de Reygersbergen: 18-19 Juli. - De door Boelen medegebrachte brieven van Ambon. - Komst van de Dispatch: 18 Juli. - Tocht van Feldmann naar hoofdplaats Saparoea en Haria: 17 Juli. - Verblijf te Saparoea van 17 op 18 en van 18 op 19 Juli. Vergadering van Groot c.s. met de rebellen op de kust van Hatawano: 19 Juli. - Het ondergane lijden van Christiaansen. - Voortzetting der correspondentie tot $20 \mathrm{Juli}$.

De gevolgen moetende aanvaarden, "dat er te Amboina met weinig overleg gehandeld werd" 1 , had de expeditie of tot op betere voorziening werkeloos kunnen blijven, óf eenvoudig moeten terugkeeren. Men bleef, doch zonder zich werkeloos te toonen. "Ik besloot daarom", leest men in het journaal-Groot, altijd ad $12 \mathrm{Juli}$, "met overleg van Kapt. Luit. Pool en $\mathrm{L}^{t}$ Ellinghuijzen om te zien of er mogelijkheid was met de Inlanders in onderhandeling te komen. Ik zond also een chaloup met een witte vlag benevens eene proclamatie aan de inwooners van Saparoea onder het heisen van de witte vlag van de beide scheepen, en het doen van een los schot ter verzeekering." Moest het met dit vertoon en na al het gebeurde er niet veel van hebben, dat Groot wilde capituleeren! Een zotte correspondentie met den wal zien wij nu openen door schuchter gezonden "brieven, op lange bamboezen gestoken" 2 :

Ziehier de vertaling van de in het Maleisch gestelde proclamatie ${ }^{3}$ :

1 Van Doren-M., bl. 60.

2 Ver Huell, dl. I, bl. 174. Wij zullen ook lezen van vlaggestokken.

3 Van Doren-M., bl. 48-49. 
Aan de inwoners van Saparoea!

Thans het oogenblik daar zijnde, om een einde aan uwe wederspannigheid te maken, zoo biedt men ulieden eenen tijd van 24 uren aan, om tot inkeer te komen. De Compagnie thans onder-rigt zijnde, dat gijl. niet te wel door den Resident behandeld zijt geworden, zoo laat eene commissie, uit uw midden gekozen, bij mij aan boord komen, die mij de belangen van ul. bekend maakt, en ik beloof $u$, dat de Compagnie, in zoo verre uwe verlangens billijk zijn, daarin zal toestemmen. De witte vlag, zoo als thans, zal van de beide oorlogsvaartuigen gedurende 24 uren blijven waaijen; en zoodra deze tijd verstreken is, zonder dat er van uwen kant tot eene onderwerping zal besloten zijn, zullen de vijandelijkheden op nieuw voortgezet worden. In ieder geval behoeft gijl. voor de aan boord gezondene Commissie niet bevreesd te zijn, deze zal vrij en zonder het minste letsel aan wal gezet worden.

Boelen verhaalt in zijn memoriaal als volgt, wat met dit weinig waardige stuk plaats vond ${ }^{1}$ :

Deze brief werd aan den stok van een witte vlag gebonden. Onder het lossen van een saluutschot werden witte vlaggen geheschen aan den voortop der beide schepen ${ }^{2}$, terwijl tegelijkertijd de jol van de rris $^{3}$, bemand met Boegineezen, naar den wal pagaaide. Daar aangeland sprong de mandoer met den stok, waaraan de vlag en de brief bevestigd waren, in de hand op het strand en bleef daar ongeveer Io minuten wachten. Niemand vertoonde zich echter om den brief aan te nemen. Wel riep men den mandoer toe dat hij zou naderen en in de Kampong komen, maar daar dit tegen zijne medegekregen bevelen was, plantte hij den stok, met den brief en de vlag, in het zand en keerde met zijne manschappen naar boord terug. Kort daarop kwam er een gewapende Inlander uit het bosch, die den stok weg nam. Ongeveer een half uur daarna riep men ons van den wal toe dat de brief gelezen was en men verzocht, dat wij niet meer zouden schieten. Nadat wij hem dit beloofd hadden, kwamen weldra vele Inlanders, allen gewapend, te voorschijn en in de platvoet zagen wij een opperhoofd op een kadèra-pikol (draagstoel) aan het strand zitten. Des avonds om 5 uur lichtten wij het zware werpanker, dat wij weer om de N.O. uitbrachten, om daardoor het schip nader aan den wal te kunnen halen, wat oorzaak was, dat men ons van den

\footnotetext{
1 Boelen-M., blz. 249-250.

2 Dit geschiedde, blijkens journaal-B., tegen $1 \frac{1}{2}$ uur in den namiddag.

3 De correspondentie kon uitgaan van de Iris, omdat toen Pool naar zijn schip terugging, Groot hem vergezelde, blijkens journaal-B.

De vooravondwacht van 4-8 uur.
} 
wal toeriep: „dat dit niet recht was" '. Toen er een jongen bezig was om op de voorbramzaling de witte vlag te klaren, die in de lijn verward geraakt was, riepen zij van den wal, dat wij die vlag niet moesten neerhalen. $\mathrm{Na}$ zonsondergang werd er van den wal gepraaid, dat op Zondag den $13^{\text {den }}$ Juli in alle kerken der negorijen de brief zou worden voorgelezen, dat op dien brief niet eerder dan Maandag daaropvolgendè zou kunnen worden geantwoord en men dus tot dien tijd uitstel verzocht. De Overste vond goed hierop niets te antwoorden. Des nachts evenwel deden wij onze gewone ronde met gewapende sloepen. Het roepen van "alles wel" door onze schildwachten werd van den wal herhaald met "Jaga, jaga" (pas op, pas op). Des Zondags den $13^{\text {den }}$ Juli 'smorgens om II uur kwam er reeds een inlander op het strand met de witte vlag, waaraan een brief was gehecht. Hij plaatste den stok in het zand en verwijderde zich. De jol van de "Iris" werd toen afgezonden om dien brief te halen, hij was in 't Maleisch en was van den volgenden inhoud: «Wij hebben uwen brief ontvangen en den inhoud er van verstaan. Prauwen hebben wij niet om aan boord te komen, doch als de kapitein aan den wal wil komen om in onzen raad (baileo) te onderhandelen, zal ons dat wel zijn. Zend ons anders de Amboineesche burgers en zwarten. Geteekend door de Opperhoofden van Ceram, Saparoa, Noesalaut.

Groot, "die niets vuriger verlangde, dan in zijn aangewende pogingen te slagen" 2 , scheen bij het wel degelijk bestaan van prauwen dit gemis aan vaartuigen niet als een voorwendsel der muiters te willen beschouwen om zich van eeu bezoek aan het oorlogsschip te onthouden; hij besloot toch in overeenstemming met Pool, om den volgenden dag "den Luitenant Ellinghuyzen, als het bevel over de landingstroepen hebbende, vergezeld van den Luitenant Christiaan, daar deze het best met de taal en de opstandelingen bekeud was" 3 , naar wal te zenden. Dientengevolge

1 Ook Groot, in zijn journaal van het planten van den brief op 12 Juli melding makende, schrijft: „Van dit moment begon de onderhandeling. In die tijd maakte ik gebruik om met het schip zoo digt onder de Negorij te komen als eenigsints de zeemanschap zulks permitteerde en vertuide weder op nieuw met een werp onder de wal en een zwaar anker naar buiten om in geval van de eerste stribbeling gebruik van die batterij te maken en te kunnen landen. Dagelijks gingen de chaloupen naar de wal om brieven te halen en te brengen."

2 Van Doren-M., bl. 50. - Daarom liet Groot zeker ook maar de 24 uren zijner proclamatie straffeloos voorbijgaan!

3 Als voren. De Schrijver zegt op bl. 48 deze „bijzonderheden en de briefwisseling met de rebellen en den Kapitein Lt. Groot gehouden" geput te hebben "uit eene geloof waardige bron". 
antwoorde Groot ${ }^{1}$, dat de Kapitein zelf niet komen kon, maar dat er een officier, vergezeld door den loods Christaansen, in den Kampong zoude verschijneu; de commissie moest echter met alle eer worden bejegend en terwijl er gedurende dien tijd geen sloepen van boord naar den wal zouden gaan, mochten er ook van hunue zijde geen prauwen van het straud in zee steken $2 !$ Om 2 uur in den namiddag van den $13^{\mathrm{n}}$ werd er weder van den wal gepraaid, dat de brief van den Kapitein naar de negorij Saparoea was opgezonden, en dat men morgen antwoord zoude hebben. Dien volgenden morgen plautten de rebellen twee witte vlaggen op het strand, naast welke eenige Inlanders bleven staan. Van boord zond men een sloep met den loods Christiaansen om de beteekenis van een en ander te vragen. De loods kwam terug met de mededeeling, dat zij nu den officier om 10 uur aan den wal verwachtten. Intusschen zag men twee stoelen en een tafel aan het strand brengen '.

Zoo begaven zich Ellinghuysen en Christianansen dien $14^{\mathrm{n}}$ aan wal. Met koele, uitdagende en trotsche houding werden zij door eenige hoofden en de overige aan het strand staande Inlanders outvangen. Toen zij zich op de stoelen aan de tafel geplaatst hadden, omringden de Inlauders hen, waarna de besprekingen aanvingen. Als de redenen van hun misnoegdheid gaven de hoofden het volgende op ${ }^{5}$ :

$\mathrm{I}^{\circ}$. Dat zij in het uitoefenen van hun godsdienst door het Nederlandsche gouvernement belemmerd werden ${ }^{6}$.

$2^{\circ}$. Dat zij met het papieren geld, door de Nederlanders ingevoerd, geen genoegen namen, omdat zij daarmede in de kerk voor de armen niet konden zorgen, dewijl zij geen papierengeld in de bus konden steken.

$3^{\circ}$. Dat, nadat het papierengeld in omloop was gebracht, de Resident het weigerde in ontvangst te nemen, maar voor te doene betalingen aan den lande zilveren specie veriangde.

$4^{\circ}$. Dat de Resident gedreigd had, hen bij weigering in den ketting te zullen sluiten en als gevangenen naar Batavia te zenden, doch dat zij, wanneer zij zilvergeld gaven, daarvan vrij zouden zijn.

$5^{\circ}$. Dat de Resident de vrijbrieven van de burgers en inwoners had afgevraagd en deze, toen hij ze in handen had, niet terug

1 Boelen-M., bl. 250.

2 Van Doren.M., bl. 50.

3 Boelen-M., bl. 250.

4 Gelijk de vorige noot.

5 Van Doren.M., bl. 51. In Boelen-M., bl 250-251 worden de redenen minder breed opgegeven; zij komen echter wel op hetzelfde neer.

6 "Het vereeren van afgoden", licht Van Doren-M. op bl. 51 noot* toe. 
wilde geven, dan tegen betaling van vijftig Sp. dollars zilver, of wel zestig in koperen munt.

60. Dat zij het inlandsche zout, de gedroogde visch en het gedroogde vleesch (dingding) zonder betaling moesten leveren.

$7^{\circ}$. Dat alle werken en leverantiën van materialen, die vroeger door de Nederlanders en Engelschen betaald werden, thans van hen kosteloos werden verlangd.

"De afgevaardigden van den Kommandant van de Maria Reygersbergen vroegen hierop, wat zij verlangden als voorwaarden, om weder tot rust en vrede te komen.

"Hierop nam een der hoofden het woord op, en werd door verscheidene inwoners ondersteund. Hij zeide, zij twee predikanten van Batavia voor de godsdienstoefening verlangden.

"Niets anders meer te verlangen hebbende, werd van weêrszijden overeengekomen, dat humne grieven ter kenuis van den Gouverneur zouden gebragt worden, en dat als eene voorloopige goede verstandhouding de witte vlag van het eiland en vau den voortop der oorlogsvaartuigen zou blijven waaijen."

Toen beide heeren om 11 uur weer an boord waren ', ontving commandant Groot een verzoekschrift der negorijen Thamahoe, Itawaka, Nolot, Toehaha en Paperoe, om Christiaansen "naar Saparoea te zenden en dár met Matulesia te onderhaudelen" 2.

Christiaansen werd hierover door den Commandant gehoord. Hij bracht tegen deze nieuwe zending geen zwarigheid in, daar hij oordeelde, naar de wijze, waarop men door de muiters ontvangen was, dat hun bedoelingen goed waren en dat zij wezentlijk niets anders verlangden dan tot onderwerping te komen. Hij nam daarom "vrijwillig op zich, naar Saparoea te gaan, en vertrok in denzelfden namiddag" ". Daar de Reygersbergen ter reede van Hatawano d.w.z. op de oostkust lag, begaf zich om 3 uur Christiaansen, voorzien van brieven voor Saparoea, met een prauw waarop de witte vlag was, naar de westkust, vau waar hij onder escorte vau rebellen over land naar hoofdplaats Saparoea ging ${ }^{*}$.

Aan den avond van dien $14^{\mathrm{n}}$ om $10 \frac{1}{2}$ uur zag men, journali-

1 Journaal van de Reygersbergen.

2 Van Doren-M., bl. 52. - Noch in Memoriaal- of Journaal-B., noch in het journaal der Reygersbergen wordt van zulk een verzoekschrift melding gemaakt. Men leest er alleen - zie bl. 250 Boelen-M. - , dat ter samenkomst het verlangen geuit werd. - Over Paperoe in het Hatawanosche, zie dl. I, bl. 474.

s Van Doren-M., bl. 52-53.

4 Boelen-M., bl. 251, zoomede in de journalen van Boelen en van de Reygers. bergen. Over de door te trekken landstreek, zie dl. I, bl. 472 v.v. 
seerde Boeleu, verscheidene flambouwen aan het strand. Aan de westkust lag de Iris, waar een flambouw naderde, onder mededeeling van den drager, dat er een brief van hoofdplaats Saparoea was gekomen. Kapitein Pool liet hem halen en kwam er mede aan boord van de Reygersbergen. Het stuk was een schrijven hetzij van de rebellen, mede onderteekend door Christiaansen, gelijk waarschijnlijk is, hetzij van Christiáansen, houdende dat men er zeer tot vrede genegen was, waarom hij aanbeval dat morgen een officier en eeu cadet mede op de hoofdplaats zouden komen. Of Groot hierop heeft geantwoord, gelijk waarschijnlijk is, en wat hij antwoordde, leest men niet in het memoriaal, noch in de journalen; in ieder geval besloot hij het bestuur te Amboina op de hoogte te stellen ' Groot's scheepsjournaal teekende toch aan: "Den 14 'savouds zond ik een orang-baaij met een officier en een brief aan het Gouvernement van Amboina om kennis van het voorgevallene te geven." Wat er den $15^{\mathrm{n}}, 16^{\mathrm{n}}, 17^{\mathrm{n}}, 18^{\mathrm{n}}$ plaats vond, deelt het jouruaal niet mede; ook noemt hij niet den officier, die naar Ambon werd gezonden en vermeldt hij evenmin diens wonderdadige terugkomst aan boord! Nochtans hebben wij hier te boekstaven een inderdaad merkwaardigen tocht. De officier was de luitenant $t / z$ Boelen, dezelfde wiens memoriaal en journaal ik al dikwerf aanhaalde.

De opstandelingen, ongeduldig geworden, schreven brief op brief aan commandant Groot ${ }^{2}$ ! Hij beantwoordde die in der minne, om tijd te wiunen, tot hij antwoord van Ambon ontvangen zou hebben. Eev brief van Dinsdag $15 \mathrm{Juli}$ hield de herhaling in van de vrang of het wezeulijk zijn vooruemen was met hen vrede te sluiten, en zoo ja, dat hij dan zelf of wel een ander officier aan wal zoude komen om met de hoofden te spreken. Opnieuw antwoordde Groot, dat het zijn ernstig verlangen was, met hen tot vrede te komen, doch dat hij zonder last van zijn overheden het schip niet kon

1 In Memoriaal-B., bl. 251 staat, dat de brief was van Christiaansen. Bij Van Doren-M., bl. 53, leest men daarentegen, dat de brief door de rebellen was onderteekend, en enkel ter geruststelling mede-onderteekend was door Christiaansen, terwijl de brief er op aandrong, „dat de Kommandant zelf in persoon aan wal zou komen"; in verband hiermede zou Groot's antwoord geweest zijn, behalve, dat hij van deze geneigdheid tot vrede zou kennis geven aan Ambon, "dat hij zonder den last van heeren Kommissarissen zijnen bodem niet kon verlaten".

2 In Journaal-B. staat ad $15 \mathrm{Juli}$ : „Men had gedurende den dag met de inwoners verscheidene mondgesprekken en ontving 3 brieven van Saproa. De laatste wierd door den Kap ${ }^{\mathrm{n}}$ Luit. Pool in dien avond aan boord gebragt. Dezelve behelsde een verzoek aan den Kapt ${ }^{\mathrm{n}}$ Groot om een officier en eadet naar Saproa te zenden." 
verlaten. Derhalve moesten zij hunne gemachtigden op een door hen te bepalen tijd aan het strand zenden, die alsdan met de door hem te zenden commissarissen zelven zouden kumnen spreken en verder den oud-luitenant Christiaansen, dien hij als een bewijs van zijn vertrouwen in hen aan wal had gezonden, zoo spoedig mogelijk laten terugkeeren. - Het duurde niet lang, of zij antwoordden, dat zij zich Zaterdagmorgen den $19^{\mathrm{n}}$ Juli ten 8 uur aan het strand zouden bevinden, om met de afgevaardigden te spreken en wat den luitenaut Christiaansen betrof, over hem behoefde geen vrees gekoesterd te worden, zoo als gebleken was uit ziju eigen handteekening, onder hun voorlantsten brief geplaatst. Stelde de Kommandant in hen vertrouwen, dan had hij als bewijs hiervan den $17^{\mathrm{n}}$ Donderdag 's morgens ten 8 uur een officier aan wal te zenden om te Saparoua te gaan onderhandelen, als wanneer zij zich, vergezeld van luitenant Christiaansen, aan het strand zouden bevinden. Den overbrenger van dien brief werd ten antwoord gegeven, dat Donderdag op het bepaalde uur een officier aan wal zoude zijn, dien zij op hun verantwoording moesten beschermen, en dat hij, Groot, op Zaturdag den $19^{\mathrm{n}}$ mede aan wal dacht te komen, alwaar hij hen dan met dien officier en luitenant Christiaansen verwachtte ${ }^{1}$. Inderdaad ging den $17^{\text {en }}$ de adelborst der $1^{\text {ste }}$ klasse FelduanN aan wal, "om als parlementair naar Saparoea te vertrekken" 2. Van dat alles meldt het scheepsjournaal niets. Het is alsof Groot er tegen op heeft gezien om zoo'n tentoonstelling van flauwhartige onnoozelheid te journaliseeren. Intusschen hebben wij als bijzonder lezenswaard te verhalen van de twee hier aangewezen tochten, een van Boelen, gaande op: den 14. ${ }^{\mathrm{n}}$ nar Ambou, een ander van Feldmann, vertrokken op den $17^{\mathrm{n}}$ naar hoofdplats Saparoea; de twee jonge officieren kwamen den $19^{\mathrm{n}}$ behouden op de Reygersbergen terug.

Wij vangen aan met de Ambonsche reis. Boelen zelf heeft haar als volgt beschreven in zijn memorial ${ }^{3}$ :

De beide kommandeerende officieren besloten nu den wapenstilstand te handhaven en zoo spoedig mogelijk het Hoofdbestuur der Molukken met de eischen der Saparoeezen in kénnis te stellen en dienaangaande zijne nadere bevelen te vernemen. De groote

1 Van Doren-M., bl. 55-56. Het verhaal is er eenigermate verward.

2 Van Doren-M., bl. 56.

3 Boelen-M., bl. 251-259. 
orembaai werd dus gewapend met twee donderbussen en gereed gemaakt om met een officier, belast met depêches en instructies voor het Hoofdbestuur, naar Amboina te vertrekken. Mij werd deze missie opgedragen. Ik vertrok des avonds te half twaalf ${ }^{1}$. Het vaartuig onder mijne bevelen was bemand met acht Europeesche matrozen, een bootsmansmaat als onderofficier, een boeginees als djoeroemoedie (stuurman), en een Javaansche mandoer met twee Javaansche matrozen, zoodat wij in 't geheel I4 man sterk waren. Vier matrozen waren gewapend met geweren, de bootsmansmaat en ik zelf met pistolen en marinesabel. Hoe stil wij ook van boord gingen, ontwaarde men toch onmiddellijk aan den wal, dat er een vaartuig werd afgezonden, want men praaide: «itoe schuitje pigie dimana?" (waar gaat dat vaartuig heen?) Natuurlijk werd hun geen antwoord gegeven ${ }^{2}$.

Het begin van de reis was zeer voorspoedig, want wij hadden den stroom mede, zoodat ik mij te halfdrie dwars van de negorij en het fortje Pelauw, op den noordkant van het eiland Haroekoe, bevond ${ }^{3}$. Gedurende den nacht zagen wij hier en daar op het gebergte van Ceram en op dat van Saparoea en Haroekoe vuren opvlammen, volgens den Boegineeschen stuurman signalen, die de vijanden met elkander wisselden. Toen wij tusschen Amboina en Haroekoe doorzeilden, zagen wij op het strand van het eiland Haroekoe bij de negorijen Rohomini en Kabauw ' een massa gewapend volk, ons uitdagende onder hun gewoon gegil. $\mathrm{Zij}$ riepen mij toe om aan land te komen. Ik liet de orembaai zoo dicht mogelijk het strand naderen en, op de witte vlag wijzende, die midden in het vaartuig aan een hoogen stok woei, riep ik hun toe, dat de Kompanie mij afgezonden had om vrede met de Saparoeezen en ook met hen te maken ${ }^{5}$. Ik zag echter weldra aan hunne voortdurende oorlogskreten en krijgsdansen, dat ze alles behalve vredelievend gestemd waren. Ook begonnen zij de prauwen aan het strand te water te brengen en aanstalten te

1 Den $14^{\mathrm{n}}$ Juli. In journaal-B. staat over het uur van vertrek $\frac{1}{4}$ vóór 8 . Over de orembaai, zie hiervóór bl. 661 .

2 Ver Huell, dl. I, bl. 175-181 beschrijft ook het wedervaren van Boelen, naar aanleiding van diens mededeelingen aan hem. Op bl. 181 staat intusschen minder aannemelijk het tegenovergestelde, nl. dat men geantwoord had en wel „naar Amboina".

${ }^{3}$ Ook Van Doren-M. zegt hier juist het tegenovergestelde, nl. op bl. 53, dat Boelen "gedurende den nacht stroom en wind tegen had". Over "Pelauw" zie hiervóór dl. I, bl. 467; met de versterking wordt bedoeld fort Hoorn.

4 Verg. bl. 651-652.

${ }^{5}$ In journaal-B. staat wel zoo waarschijnlijk, dat Boelen had geroepen: „dat de Compagnie met Saparoea vrede wilde maken, en ik dus een witte vlag voerde". Zoo ook bij Ver Huell, dl. I, bl. 175-176. 
maken om mij aan te vallen. Zoodra zij echter zagen, dat ik gereed was een donderbus op hen af te vuren, staakten zij hunne beweging.

Te 7 uur in den morgen van den $15^{\text {den }}$ Juli kwam ik te Haroekoe aan. Het fortje aldaar, Zeelandia, is niets meer dan een blokhuis, waartegen eene woning gebouwd is, dienende tot verblijf van den kommandeerenden officier en den posthouder. De kommandeerende officier, kapitein der infanterie Van Driel, had om het fort een ruim kampement, afgesloten door, eene borstwering, doen aanleggen. De negorij, op circa drie honderd pas ten zuiden van het fort, was daarin gesloten. Hierdoor bedwong hij de bevolking, die uit eigen wil of onder den dwang van het hoofd der oproerlingen tot muiterij zoude willen overslaan. De bezetting had in het begin van den opstand hoogst zorgvolle tijdstippen doorleefd, zoowel in de eerste dagen toen ze slechts uit een klein marine-detachement, onder bevel van den adelborst $\mathrm{I}^{\mathrm{e}}$ klasse W. D. Musquetier, bestond, als later 30 Mei en 3 en 9 Juni, toen ze zeer krachtige aanvallen van de muitelingen heeft afgeslagen. Daar intusschen alle gemeenschap buiten de sterkte met de rest van het eiland afgebroken was, begon schaarste aan levensmiddelen zich te doen gevoelen en zoude men weldra aan de bevolking der kampong het noodige voedsel niet meer kunnen verstrekken. Hierdoor werd ik zeer in mijn verwachting teleurgesteld om mijn volk, na een zoo vermoeienden nacht, door spijs en drank behoorlijk te doen verkwikken. Mijne manschappen waren te veel vermoeid om al dadelijk de reis van Haroekoe naar Amboina voort te zetten. Daar zij dus eenige rust noodig hadden en mijne zending daarop niet wachten mocht, verzocht ik den kapitein Van Driel mij door eene prauw van de kampong, binnen de sterkte gelegen, te doen overbrengen naar de negorij Soeli, de eerste negorij om den oosthoek van het eiland Amboina ${ }^{1}$. Kapitein van Driel bragt mij onder het oog, dat die overtocht niet zonder gevaar zoude zijn, daar de muitelingen druk kruisende waren tusschen Ambon en Haroekoe en twee nachten geleden op Tenga-Tenga waren geland en van de nog vreedzame bevolking acht hadden vermoord en hunne afgehouwen hoofden hadden medegenomen. Het was dus zaak om naar alle kanten goed uit te kijken. Om 8 uur vertrok ik met de prauw, door 14 man voortgeroeid, naar de Oostbaai van Amboina 2. Doch, ondanks alle inspanning der Inlanders,

1 Zie over Soeli en het een paar regels verder vermelde Tenga tenga, dl. I, bl. 419.

2 Het vertrek in den avond van $15 \mathrm{Juli}$. In journaal-B. staat, dat met de prauw ook zijn menschen medegingen, „mijn volk", d.w. z. behalve de 14 "Indianen, die nu als scheppers uitsluitend dienst deden". 
konden zij die niet bereiken. Het stormde uit het Oosten met zware regenvlagen. Boven het ver in zee zich uitstrekkende rif van Soeli konden wij onmogelijk komen, daar de branding met hooge zee zich ver te loefwaarts van ons vaartuig uitstrekte. Ik besloot dus af te houden naar de bocht van Toeléhoe ${ }^{1}$, ofschoon dit besluit niet boven bedenking verheven was, want ik had niet de minste zekerheid, dat deze Mohammedaansche negorij niet tot de partij der opstandelingen was overgegaan. De bevolking van Toeléhoe deed zich echter als vredelievend kennen ${ }^{2}$. Ik liet de prauw met de $\mathrm{I}_{4}$ roeiers weder naar Haroekoe teruggaan ${ }^{3}$ en kreeg den volgenden morgen van den Radja een draagstoel, door 4 kloeke kerels gedragen, om over land naar Soeli te gaan, een prachtige tocht door de heerlijke bosschen, vol van het geschreeuw der lorries en der kaketoes ". Te half drie in den namiddag was ik te Soeli. Van hier ging ik per kleine prauw naar de Pas Bagoeala, wandelde die landengte over en stak weder per éénpersoons prauw de binnenbaai over, waarvan de bodem bedekt was met het prachtigste tapijt van koraalgewassen, dat men zich denken kan. Om half zes des avonds kwam ik te Amboina in het fort Victoria aan ${ }^{5}$. Ik begaf mij dadelijk naar het residentie-huis van den Gouverneur der Molukken. Toen ik de reden van mijne komst opgegeven had, werd ik bij Zijne Excellentie toegelaten, dien ik aantrof in zijn slaapkamer, zittende met het bovenlijf geheel naakt op den rand van zijn ledikant. Gouverneur van Middelkoop was een zeer zwaarlijvig man, die veel hinder van de warmte had en daarom volgens gebruik van de oudgasten der O.-I. Kompagnie, zich van tijd tot tijd lekker maakte door het gebruik van een luchtbad. Domine Kam zat, op eenigen afstand van zijn ledekant in een Indische luierstoel, op zijn gemak met den Gouverneur te converseeren $\ldots{ }^{6}$

1 Toelehoe: zie dl. I, bl. 419.

2 Er schijnt daar een bezetting gelegen te hebben, want Boelen teekent in zijn journaal aan, dat hij „door den commanderenden officier aldaar zeer goed ontvangen (werd)".

s Dus alleen de roeiers; zijn van de Reygersbergen medegebrachte volk bezorgde hij, volgens het journaal, „een goed kwartier".

4 Het journaal-B. zegt niets van dat fraaie. Het Memoriaal is een later net opgeknapt stuk. In het journaal staat alleen van dien tocht in een draagstoel naar Soeli: „dog de weg was zodanig slegt en ongangbaer, dat ik genoodzaakt was om uit de stoel te gaan en den weg te voet te lopen".

"In bet journaal-B. staat: "waar ik des avonds ten $9 \frac{1}{2}$ uur aankwam".

6 Nu volgt in het memoriaal een minder vriendelijke uitweiding over dominé Kam, bl. 254-255, die met den tocht geen verband houdt en alzoo ook niet in het journaal-B. voorkomt. Omdat het speciaal Christenen waren, die zich aan de wreedheden op de onzen en het verzet schuldig makten, stond de 
Het souper dien avond bij den gouverneur smaakte mij overheerlijk en na de nachtrust ten huize van den secretaris Baumhauer, was ik den volgenden dag weder een nieuw mensch, want ik was uitgehongerd en zeer vermoeid geweest. Toen de depêches van heeren Commissarissen aan overste Groot gereed waren, maakte ik aanstalten tot de terugreis. Vermoedende, dat ik op dezen tocht meer last van den vijand zou hebben dan ik van boord komende ondervonden had, vroeg ik aan den kommandant van Amboina, den overste Kraaijenhof, mij nog drie geweren met gevulde patroontasschen te willen medegeven. Die ontvangen hebbende, vertrok $\mathrm{ik}$, den $\mathrm{I} 7^{\text {den }}$ Juli 's morgens te half acht ${ }^{1}$, in eene kleine prauw naar den pas Bagoeala. Daar aangeland, liet ik bij het blokhuis het kamponghoofd ontbieden. Doch deze scheen niet bereid $\mathrm{mij}$ aan een vaartuig te helpen, waarmede ik naar Soeli kon gaan ${ }^{2}$. Hij beweerde geen prauw te hebben en dat niemand in zijn kampong dien tocht zou willen ondernemen. Ten slotte werkte mijn dreigen toch zooveet uit, dat ik eene prauw met 4 man tot mijn dienst kreeg. De oostmoesson woei dien dag zeer sterk en, daar de wind recht de baai in stond, hadden de inlanders veel moeite om tegen de hooge zee op te roeien. Ondanks kracht van pagaaien vorderden wij slechts weinig. Ten laatste stelden de inlanders voor om met de prauw aan het strand van den noordkant van de baai te landen en mij langs dat strand naar Soeli te geleiden. Ik stemde daarin toe. De prauw richtte haar steven naar het strand en kwam hoog genoeg op het droge te zitten, dat zij er uit konden springen zonder door de branding overgoten te worden. Maar nauwelijks was ik zelf op strand, of de vier mannen stieten de prauw weder af naar zee en sprongen er in. Hoe snel en behendig dit ook in zijn werk ging, was ik toch genoeg bij de hand om een hunner bij het haar te grijpen en achterover op het strand te doen vallen, hem mijn sabel op de borst houdende. Intusschen pagaaiden de drie overigen met de prauw naar zee, mijn vier geweren en gevulde patroontasschen medenemende. Ik besloot nu met mijnen Ambonees naar Soeli te wandelen. Ik liet hem vooruit loopen en volgde hem met de sabel in de hand. Weldra kwamen wij aan een rivier, die wij moesten doorwaden en die

bekeeringsijver destijds bij onze militairen al in een heel slecht blaadje. Ook in Ver Huell's "Herinneringen" vinden wij het afgeven uit dien hoofde op het inlandsche christendom. Ik kan mij die opvatting onder de indrukken van het gebeurde wel begrijpen, maar nam er niets van over. 't Is alsof aan Europeesche christenen beestachtig handelen vreemd zou zijn!

1 Half negen staat in het journaal-B.

2 Verg. bl. 632, alinea 2. 
nog al vrij diep was. Ik bleef nu een oogenblik in tweestrijd of ik den Amboinees vóór mij of achter mij door de rivier zou laten gaan. Achter mij vertrouwde ik hem niet het minst en vóór mij, dacht ik, kan hij, eerder aan den oever zijnde, mij wel bij het hoofd pakken en mij, onder water houdende, afmaken, want hij had, zooals de Amboineezen gewoonlijk hebben, zijn pareng (langwerpig hakmes) bij zich. Vóór mij uit, leek mij nog het secuurste. $\mathrm{Na}$ drie zulke rivieren te hebben doorwaad, kwam ik eindelijk te Soeli aan, druipnat, maar toch verhit en vermoeid. Mijn Amboinees werd in arrest genomen even als wat later de drie anderen, die het toch raadzamer schenen gevonden te hebben om zich in Soeli weder bij mij te voegen. Zoo kwam ik weder in 't bezit van mijne geweren en patroontasschen. Per draagstoel ging ik weder naar Toeléhoe, waar ik te half zeven in den avond van den $I 7^{\text {den }}$ Juli aankwam '. Van hier ging ik den volgenden morgen om 4 uur per prauw naar Haroekoe, dat ik om 8 uur bereikte en waar ik mijn volk van den oremb\$ai vroolijk en gezond terugvond ${ }^{2}$. Kapitein Van Driel had nog voortdurend nachtelijke aanvallen af te slaan. De muitelingen werden hoe langer hoe talrijker en vermeteler. Hij schatte hun aantal, bij den laatsten aanval van den vorigen nacht, op wel 4000. Hij had veel hulp gehad van de matrozen onder den luitenant ter zee $2^{\text {de }}$ klasse Veerman, die gedetacheerd waren op het schip «de Zwaluw", een engelsche koopvaarder, thans gehuurd door het Nederlandsche gouvernement om den kruidnageloogst in te zamelen. Dit schip lag nu voor het fort van Haroekoe en tijdens den aanval had luitenant Veerman zijn matrozen met twee veldstukjes aan den wal gezonden, ter assistentie van kapitein Van Driel. Veerman vertelde mij, dat het af halen der kruidnagelen met veel moeielijkheden gepaard ging, daar de in opstand gekomen kampongs natuurlijk weigerden hun oogst af te leveren.

1 Er staat gedrukt den $18^{\mathrm{n}}$, doch ik beschouw dit als een fout; ook bij Ver Huell, dl. I, bl. 176, den $17^{\mathrm{n}}$. - In het journaal-B. staat van dezen geheelen tocht Bagoeala-Soeli, waarbij Boelen zich verklaart "genoeg bij de hand", niets anders dan: „Om $8 \frac{1}{2}$ uur vertrok ik van Amboyna met brieven voor Haroka en de schepen van Hatawana gelegen. Na een zeer vermoeilijke reis

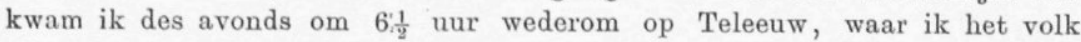
alle gezond en wel te vreden vond." In dezen geest ook vermeld in Ver Huell, dl. I, bl. 176 .

${ }^{2}$ Ik vermoed, dat dit mede onjuist is. Op bl. 676, noot 3 teekende ik aan, dat volgens het journaal-B., Boelen zijn volk een goed kwartier te Telehoe bezorgde, terwijl hij hen, blijkens de vorige noot dáár gezond en tevreden terugvond, waarmede dan verder verband houdt de mededeeling in het journaal: "Om 4 uur des 's morgens vertrok ik met twee orangbaaien door negers van Telehoe geroeid wederom naar Haroeka, waar ik om 8 uur aankwam." 
Ik had den wakkeren kapitein van Driel en mijn kameraad Veerman gaarne in hunne moeilijke positie willen bijstaan ${ }^{1}$, maar ik moest naar de "Maria Reygersbergen" terug. Mijne 8 Europeesche matrozen hadden nu ieder een geweer. De orembaai werd ter dege nagezien, evenals de wapenen en de amunitie, ook de twee donderbussen ondergingen eene grondige examinatie en des avonds om 9 uur, toen de maan ondergegaan was, aanvaardden wij de reis naar den hoek van Hatawana. Bij mijn vertrek ried kapitein Van Driel mij de grootste voorzichtigheid aan, want, zeide hij, dat gij verraden zijt en men uwe gangen nagaat, daarop kunt gij rekenen. Wij hadden den moesson en den stroom tegen, die sterk om de west trok, zoodat ik wel berekenen kon, dat wij eerst den volgenden dag tegen den middag aan boord van het fregat konden zijn. Voor dat het vaartuig zich in beweging stelde, had ik ieder man zijn plaats doen nemen, hem gewezen hoe hij zijn geweer, gereed om er mede te kunnen ageeren, bij zich moest laten staan en hem vermaand zorg te dragen, dat er met het pagaaien geen waterspatten op zijn geweer en vooral niet op het slot kwamen. In den voornacht gebeurde er niets bijzonders. Wel zagen wij, evenals op de uitreis, van tijd tot tijd in het gebergte van Ceram en dat van Saparoea en Haroekoe vuren opvlammen. Na middernacht het fort Pelauw passeerende, constateerde ik, dat wij slechts langzaam, wegens den fellen stroom, vorderden en de dag reeds ver gevorderd zoude zijn, vóór wij ons onder de bescherming van het geschut onzer oorlogschepen zouden bevinden. Het opkomen der zon werd dien nacht vooraf gegaan door het verschijnen boven de kim van de morgenster Venus, zoo schitterend als ik deze ster, hetzij als morgen- of avondster, nooit meer gezien heb. Door het nu allengs helderder worden van de oosterkim, konden wij weer beter voor ons uit zien, en ontwaarden wij weldra, dat zich eene linie van vaartuigen dwars in onze koerslijn geposteerd had ${ }^{2}$. Ik hoopte; dat de witte vlag, die nog altijd midden in het vaartuig wapperde, ons voor een vijandelijken aanval zou vrijwaren, maar al spoedig bemerkte $\mathrm{ik}$, dat de bemanning dier vaartuigen zeer vijandig gezind was. $\mathrm{Zij}$ hadden roode vlaggen van hunne toppen waaien, dansten en gilden als bezetenen, met hunne klewangs zwaaiende en snaphaanschoten op ons lossende, die echter niemand letsel deden. Jullie wilt dus vechten, dacht ik, welaan dan moet de witte vlag over-

1 Waarom? Was er dan geen "moeilijke positie" voor Hatawano? Het verhaal kon hier en daar wel wat eenvoudiger geweest zijn.

${ }^{2}$ Het aantal vaartuigen van de linie was 6 , blijkens de volgende bladzijde. De redding is overigens wonderdadig, vooral ook als men in aanmerking neemt hoe snel deze Inlanders hun vaartuigen kunnen voortpagaaien. 
boord en tegelijkertijd nam ik den vlaggestok en wierp dien met de vlag overboord '. Toen zeide ik tot mijn volk: "Mannen, hier moeten wij doen, wat wij kunnen en ons leven tot het uiterste verdedigen, laat ieder nauwkeurig doen wat ik beveel." - «Wij moeten terugkeeren", zei een der matrozen. - «Aan terugkeeren valt niet te denken. Houdt uwe geweren gereed; mandoer! houd recht op die groote prauw aan en nu roeien met alle macht." De prauwen, die ik voor mij had, zes in getal, waren echelons. gewijze opgesteld, terwijl nog andere prauwen, met krijgsvolk bemand, van het strand in zee staken. Intusschen pagaaiden wij met snelheid op hen aan. Geweerschoten werden op ons gelost, maar niemand onzer werd getroffen. Toen ik het grootste hunner vaartuigen tot op pistoolschotsafstand genaderd was, kommandeerde ik: «bakboord vaardig" en, terwijl de mandoer onzer orembaai die prauw als 't ware strijkelings voorover deed loopen, kommandeerde ik "vuur". De kogels uit de vier geweren troffen in een drom van menschen, daar het inlandsche vaartuig door drie boven elkander zittende rijen roeiers werd voortgestuwd. Gelijktijdig met het lossen der vier geweerschoten, vuurde ik de achterste donderbus af, die, met schroot geladen, eene vreeselijke slachting in het vaartuig aanrichtte. Door het uitmuntende beleid van den mandoer met zijn stuurpagaai, kreeg ook de tweede prauw haar deel, ditmaal van stuurboord, en het schot uit de voorste donderbus, bediend door den bootsmansmaat, trof niet minder goed. Dit onthaal scheen de vijand van ons niet verwacht te hebben. Zij lieten de riemen hangen, alsof in eens hunne armen verlamd waren, terwijl er uit de vaartuigen een groot gekerm opsteeg. Een van de achterste prauwen, een groote kruisprauw, wilde ons nog den weg versperren, maar een nieuwe losbranding van de geweren aan bakboord en een schrootschot uit de achterste donderbus, waarbij ik ook nog mijne pistolen loste, deed hen afdeinzen ${ }^{2}$. $\mathrm{Nu}$ namen de bootsmansmaat en ik ook een pagaai ter hand en vlogen wij met buitengewone snelheid voort. Wel kwamen de vijandelijke prauwen ons achterop, maar zij verloren te veel tijd met het overladen hunner dooden en gekwetsten in andere prauwen, om ons nog te kunnen inhalen, zoodat wij ze achtereenvolgens weder naar den wal zagen sturen en om den hoek van

1 De vlag kon dus niet ingehaald worden; ze moest over boord!

2 In het journaal-B. staat nog: „Ongelukkig had een van het volk eerst een groot uur geleden van Haroka vertrokken, de lont in het water laten vallen; daarbij sprong met het eerste schot het slot van de donderbuks; het tweede schot stak ik af door een geladen pistool, dat ik bij mij had liggen." Dit leest men ook bij Ver Huell, dl. I, bl. 179. 
het land verdwijnen. Later heb ik vernomen, dat de beide aanvoerders van dit prauwen-eskader bij hunne tehuiskomst, wegens den noodlottigen afloop van het gevecht, door het opperhoofd der opstandelingen onthoofd werden....

In den namiddag van den $19^{\text {den }}$ Juli kwamen wij weder aan boord van het fregat ${ }^{1}$.

Wat de brieven hebben ingehouden, die wakkere Boelen van Ambon voor commandant Groot medebracht, weet ik niet. Bij Van Doren lezen wij ${ }^{2}$, dat de Moluksche commissie den gouverneur Van Middelkoop "benoemd" had, "om in persoon de onderhandelingen te gaan voortzetten"; doch daar commandant Groot door ontvangen berichten over de gezindheid der muiters "overtuigd" was, "dat zij met niemand wilden onderhandelen dan met eene kommissie, door de kommissarissen van Java derwaarts gezonden", heeft hij die malle zending althans ontraden. Er zou echter nog heel wat gebeuren, alvorens ook voor hem zekerheid was verkregen, dat de koelies de heeren eenvoudig voor den gek hielden.

Tijdens de terugreis van Boelen was den $18^{\mathrm{n}}$ de Dispatch van Ambon mede bij de Reygersbergen ten anker gekomen. Het vaartuig bracht o. a. aan een versterking van 25 Amboneesche burgers. Commandant Groot gaf gezagvoerder Crozier last, gelijk in het journaal van den $18^{\text {n }}$ staat opgeteekend, "om ook de witte vlag te hijsen, en geene vijandelijkheden te doen geduurende de onderhandeling".

Met die onderhandeling werd in de cerste plaats adelborst Feldmann belast, naar wij lazen; daartoe was hij, evenals de oude Christiaansen, naar de muitelingen gezonden; onverantwoordelijke handeling van commandant Groot, na de wijze waarop de rebellen zich hadden doen kennen. "Wie siddert niet", schreef Ver Huell 3, "bij het vernemen van de doodsangsten en folteringen, welke deze jouge officier heeft moeten doorstaan, daar hij alleen afhing van de grilligheden van het vermetel Opperhoofd der muitelingen, en zijn leven, als het ware, slechts aan een hair gehangen heeft !"

1 Er staat gedrukt den $20^{n} ;$ m. z. den $19^{n}$. Verg. de noot 1 op bl. 678. Wij zullen in noot 3 van bl. 689 gelegenheid hebben meer data-fouten in het Memoriaal op te merken. - In het journaal-B. is nog aangeteekend: „Men had op ons circa 24 geweerschoten gedaan, waarvan sommige goed gerigt, dog gelukkig is geen onzer gekwest. Om $11 \frac{1}{2}$ uur kwam ik wederom aan boord van het fregat M. R. en vond het schip the Dispateh voor Hatawano geankerd. Op de 3 scheepen had men nog de witte vlag waaijen." Het goed gericht vuur, waardoor niemand werd gekwetst, vat ik niet.

2 Van Doren-M., bl. 59-60.

3 Ver Huell, dl. I, bl. 188-189. 
Zooals wij ons zullen herinneren, was Feldmann den $17^{\mathrm{n}}$ Juli van de Reygersbergen aan wal gestapt. Wat de jonge officier toen heeft moeten lijden, kunnen wij lezen in het verhaal, dat uit zijn mond door Ver Huell is opgeteekend geworden en hier volgt ${ }^{1}$ :

Ingevolge order van den Kapitein Luitenant ter zee J. Groot, kommanderende Z. M. fregat Maria Reigersbergen, liggende voor de negorij Hatoeana op het eiland Saparoua, vertrok ik op den 17 Juli 1817 , des morgens ten 8 ure, als Parlementair naar Saparoua. Met de sloep aan wal gekomen zijnde, werd ik dadelijk door eene inlandsche burgerwacht van zes man naar de tweede digt bij zijnde negorij Jahamao getransporteerd, alwaar ik mij, benevens gemelde wacht, in een visschers praauwtje begaf, hetwelk mij aan de overzijde van de bogt bragt, waarna ik mij op weg landwaarts in naar de negorij Saparoua begaf 2. Op gemelden weg ontmoette ik op kleine afstanden eene wacht van inlanders, die zich mede achter mij vervoegde, zoodat ik op het laatst, in plaats van zes man, er over de veertig bij mij had. Digt bij Saparoua gekomen zijnde, werd mij door de wacht gezegd, om hier te moeten wachten, waarop zij eenige van hen naar het Opperhoofd zonden, om hem van mijne aankomst te verwittigen. Een half uur daar gestaan hebbende, hoorde ik van verre in het bosch een groot geschreeuw der inlanders, en eenigen tijd daarna zag ik, volgens mijne gissing, ruim zeshonderd eilanders gewapend met geweren, sabels, pieken, klewangs, pijlen, enz. op mij aankomen, met Matulesia aan het hoofd, voorafgegaan door een twintigtal Alfoeren, die tot digt vóór mij kwamen, en al dreigende, om mij met hunne pieken te willen doorsteken. De Kapitein was toen op dat oogenblik zeer eenvoudig op inlandsche wijze gekleed, gewapend met twee pistolen in een' gordel om zijn lijf, en eene groote klewang in zijne handen. $\mathrm{Na}$ mij eenigen tijd met een verachtend oog aangezien te hebben, zonder een woord te spreken, gebood hij, zich eindelijk omdraaijende, dat ik hem volgen moest. Op Saparoua gekomen zijnde, zag ik een groot plein, waar eene overdekte loods stond, hetwelk hun verblijf was ${ }^{3}$. Om hetzelve werd ik driemaal henen geleid, waarna het Opperhoofd zich in de loods begaf, en mij op het plein vóór dezelve liet staan, gevende mij den vlaggestok, waaraan de witte vlag waaide, die ik mede gebracht had, in de hand. Daarop schaarden zich toen alle de ge-

1 Ver Huell, dl. I, bl. 181-188.

2 Jahamao zal wel zijn Ihamaoe; wat bedoeld wordt met de overzijde van de bocht, weet ik niet. - Van een ontmoeting met Christiaansen zien wij geen melding gemaakt.

s De loods, vermeld op bl. 616 , noot 5 ? 
wapende manschappen om mij heen; en op zijn' wenk rigtten al de manschappen hunne wapens op mij aan, even of ik zoo ter neder zou geschoten worden. Toen liet het Opperhoofd mij voor het eerst vragen: Wat ik kwam doen? Ik antwoordde, dat ik, volgens zijn verlangen, gezonden was, om de Radja's, die op zaterdag den $19^{\text {den }}$ dezer zich naar Hatoeana zouden begeven, af te halen, en met hen derwaarts zoude vertrekken, zoo als, reeds eenige dagen te voren, door den Overste aan hem geschreven was. Hierop liet hij de omstanders, die rondom mij geschaard waren, uit elkander gaan, en hunne geweren weder op nieuw op mij aanleggen. Toen dacht ik niets anders, of ik zou met een generale decharge ter neder geschoten worden. Hij liet mij voor de tweede maal dezelfde vraag doen, er bijvoegende, waarom er geen kadet was medegekomen, zoo als hij geschreven had. Ik antwoordde hem, dat men zijn' brief dan niet goed begrepen had, dat dit anders wel zou gebeurd zijn. Of ik dit alles op mijne wapens kon bezweren, waarop ik ja! antwoordde. Daarop werd mij de degen afgenomen en aan hem overgegeven: bij mijn vertrek heb ik dien eerst weder terug gekregen. Alstoen werd ik bij hem onder de loods gebragt. Ik zette mij op een' stoel neder, terwijl zich al de gewapende manschappen om mij heen schaarden. Een oogenblik stil gezeten hebbende, vroeg hij mij, wat het voor een schip was, dat dezen morgen op Hatoeana gekomen was ${ }^{1}$. Ik antwoordde hem, dat ik dat niet wist; dat ik, bij mijn vertrek van boord, het schip wel van verre gezien had, maar hetzelve niet had kunnen onderscheiden; waarop hij toornig wordende, mij gelastte, om dadelijk aan den Overste te schrijven, en te vragen, wat schip het was, wat het kwam doen, en waar het van daan kwam? dat de Kapitein, of een Officier, van het schip nog dezen avond bij hem moest komen. Hij liet mij papier, pen en inkt geven, en, toen ik dit alles geschreven had, liet ik hem vragen', of hij daarbij nog iets wilde gevoegd hebben, en of hij den brief ook wilde lezen. Ik zeide hem zulks, om hem niet in het denkbeeld te brengen, dat ik mij over zijn gedrag omtrent mij zou beklagen; doch hij van zijn' stoel opspringende, kwam naar mij toe, zette zijne groote klewang mij in den nek, en voegde er de woorden bij: «kapot of niet kapot!» Dit was een oogenblik voor mij, of ik wegzonk; en zoo werd ik meermalen door hem bedreigd. Hij liet den brief dadelijk bezorgen ${ }^{2}$, en ging daarop heen, liet mij met de Radja's en overige manschappen in de loods blijven.

1 Zie bl. 681 , alinea 2.

${ }^{2}$ Ad 18 Juli staat in het journaal-B.: "Om $1 \frac{1}{2}$ uur ontvangen een brief van den eadet Veltman, welke de Kaptn. beantwoordde." 
Een half uur daar gewacht hebbende, kwam hij onder een groot geschreeuw der inlanders terug, hebbende zich nu gekleed in eene lange witte broek, witte kousen, schoenen, en een roode Engelsche frak met twee Luitenants-Kolonels epauletten er op, die van den Majoor BEETJES afkomstig waren 1, als ook met.een' driekanten hoed, waarop eene pluim van zwarte en roode veren, en eene groote sleepsabel in zijne hand. Nadat hij eenige malen, even als een razende hond, de loods op en neêr had gewandeld, zeide hij tegen mij: «Kom!» waarop hij vooruit, en ik achter hem, en daarna zijn gevolg de negorij inging, en zoo langs het residentiehuis en het fort naar het strand wandelde. Daar zag hij door zijn' verrekijker de baai uit, of er ook schepen in het gezigt waren. Niets ziende, keerden wij weder terug, waarop hij beneden aan de stoep van het residentiehuis op een' stoel ging zitten, en mij zeide van naast hem te gaan staan. Alstoen hield hij inspectie over zijne gewapende manschappen, die bij hem waren, aan mij vragende, of ik al dat volk en hunne wapens wel gezien had? Toen ik, ja! antwoordde, zeide hij, dat dit maar een gedeelte volks was, maar dat hij er nog duizenden meer had. Hij bragt mij toen verder in een huis, waar hij mij een glas Sagueer liet drinken. In dien tusschentijd liet hij zijn paard voor de deur brengen, ging er vervolgens op zitten, en liet mij in mijne montering, gebonden aan den staart van het paard, naar de negorij Haria, waar zijne moeder woonde, achterna loopen. Daar het reeds middag was, en dus op het heetst van den dag, en ik 's morgens al een uur geloopen had, kon ik dit loopen achter het paard niet lang uithouden. Hem om ampon verzoekende, werd ik, op aanhoudend smeeken, losgemaakt. Toen werd ik geleid tusschen twee Radja's. Gedurende dezen weg, die een groot uur lang is, werd ik elk oogenblik op het onverwachtst door een verschrikkelijk geschreeuw van omtrent veertig gewapende inlanders, die zich in het lange gras verscholen hadden, aangevallen, en met hunne wapens bedreigd, even of men mij wilde vermoorden. Verscheidene stooten en slagen heb ik bij die gelegenheid bekomen; en, ware ik niét door twee Radja's begeleid geworden, zeker zou men mij op dien weg vermoord hebben. Daar hij nu te paard zittende vooruit was gereden, kwam hij naderhand mij weder terug opzoeken, en vroeg mij, of zij mij niet kapot hadden willen maken? Toen ik hem ja! antwoordde, zeide hij mij, dat dit ook zeker zou gebeurd zijn, indien hij er niet bij was geweest. Op Haria gekomen zijnde, bragt hij mij bij zijne moeder aan huis, eene oude vrouw, die mij met een medelijdend oog aanzag, doch geen woord tegen mij gesproken heeft. Hij liet

1 Beetjes was echter majoor. 
daar twee soldaten, die van de Expeditie van den Majoor BeEtjes gevangen genomen en nu op zijn inlandsch gekleed waren, voor mij brengen '. Die menschen dachten, dat ik hun verlosser was; doch te vergeefs; zij moesten mij vertellen, hoe zij gevangen genomen waren, en hoe de overige menschen van die mislukte Expeditie vermoord waren; daarna werden zij weder naar hunne gevangenis gebragt. Het was hier, dat wij bij zijne moeder aan huis ons middagmaal ontvingen, waarbij verscheidene Radja's tegenwoordig waren. Bij die gelegenheid vroeg hij $\mathrm{mij}$, of ik nog ouders had, en wat zij deden? Toen ik hem antwoordde, dat mijn vader Predikant was, vertelde hij dit aanstonds in het rond, en allen zagen mij toen met verwondering aan, en sloegen hunne handen te zamen; en van dat oogenblik af aan, werd ik beter behandeld. Hij wilde mijn vader als Resident hier bij zich hebben; dit moest ik dezen schrijven, zoo als ik hem dan ook maar alles beloofde. Tegen den avond vertrokken wij weder naar Saparoua; doch ik bleef toen van de herhaling der ontzettende tooneelen, die mij 's morgens waren bejegend, gelukkig bevrijd. Des nachts wilde hij mij alleen in een huis laten slapen; ik verzocht van bij hem te blijven, dewijl ik anders mijn leven niet zeker was. Dit stond hij mij toe, en toen heb ik de beide nachten in de loods, onder al die gewapende manschappen, naast hem op een matje, zonder uit de kleederen te komen, onder het geraas van trommelen en zingen, terwijl hij soms met mij een dobbelspel wilde spelen, doorgebragt. Des anderen daags ging hij met mij rondwandelen, doch liet mij niets van het fort zien. Dan nam hij mij eens aan de hand, even of ik zijn kind was, en dan had hij weder opwellingen van drift, zoo dat ik altoos op mijne hoede moest zijn, en hem in alles maar trachtte te voldoen. Hetgeen hij deed, aapte ik getrouw na, zoo als bij voorbeeld bij het passeren van de kerk op Haria. Op een' kleinen afstand nog van daar zijnde, nam hij zijn hoed al af, en vouwde zijne handen te zamen, hetwelk ik in alle opzigten volgde, en zoo heb ik de beide dagen met hem doorgebragt; bij afwisseling was hij goed van humeur, en dan weêr als een razende. Den $19^{\text {den }}$ Julij liet hij mij des morgens met eene wacht naar Hatoeana, waar het fregat was blijven liggen, terugbrengen. Ik vroeg hem bij mijn vertrek, of hij niet medeging, hetwelk hij met neen beantwoordde, maar mij zeide, dat zich eenige Radja's op Hatoeana zouden bevinden, en dat ik aan den Overste moest zeggen, van daar ook te komen, om met hen te onderhandelen.... Bij mijn vertrek moest ik hem belooven, dat ik hem een zwart zijden vest en wat buskruid zoude sturen, zoo als bleek

1 Over deze twee Europeanen, bl. 623. 
uit een' brief, door hem zelf geschreven, dien hij mij dadelijk, toen ik aan boord was, nazond, doch waaraan natuurlijk geen gevolg werd gegeven; alzoo ik maar alles beloofde, om mij niet op eene ellendige wijs te zien mishandelen.

Aldus kwam Feldmann, kort ua Boelen, behouden maar met "bleek, ingevallen gelaat" op de Reygersbergen terug ${ }^{1}$. Christiaansen had men niet mede naar boord laten gaan; hij moest, volgens Feldmann, ook veel verduren; tevens deelde de Adelborst mede, dat de regenten aan het strand vergaderd waren en er den Commandant opwachtten ${ }^{2}$. Was het, dat commandaut Groot zich niet minder wilde toonen, dan de ondergeschikten, die hij nagenoeg ten verderve had bevolen; was het, dat hij Christiaansen niet aan zijn lot meende te moeten overlaten; of deelde hij in gemoede nog de onnoozele verwachting, dat werkelijk deze nieuwe waaghalzerij van eenig nut voor den lande kon zijn? Hoe ook, hij liet zich denzelfden $19^{\mathrm{n}}$ om 2 uur naar het strand roeien, vergezeld door kapitein Crozier, "die de Maleische taal magtig was", den luitenant Ellinghuijzen en twee mariniers. Met een hoopvol gemoed ging dit echter niet, want, zegt het journaal van de Reygersbergen, Feldmann's mededeelingen wekten weinig vertrouwen op de gezindheid der rebellen, "waarom ik order gaf", teekent Groot aan, "de chaloupen gewapend aan boord klaar te houden, en de batterijen op de scheepen op het door mij afgesproken sein dadelijk te kunnen vuuren, hebbende ten dien einde alle de stukken op t' Punt onzer bijeenkomst gepointeerd". Aan wal gekomen werden Groot en zijn gevolg door vier regenten opgewacht en geleid naar een groote pondok, alwaar de hoofden deftig in zwarte rokken gedost en ongewapend vergaderd bleken en tevens Christiaansen werd aangetroffen. Naar het journaal mededeelt, werden zij dan ook "met de meest mooglijkste attentie ontvangen, €n volgens miju idée zelfs met te veel, hetwelk mij nog meer suspitie gaf". Groot kwam dadelijk, na gezeten te zijn, tot de vraag

1 Boelen-M., bl. 260. In het journaal-B. leest men ad $19 \mathrm{Juli}$ : „Langs het strand op de weg van Saproa zag men een inlandsche wagt met de witte vlag, welke den kadet $1^{\text {sto }}$ klasse Veldman en den loods Christiaansen naar huis geleide; dezelve praaijde ons om eene chaloup te zenden. Den Heer Veltman kwam aan boord welke ons de geweldige folteringen en mishandelingen verhaalde die hij gedurende den tijd op Saproa zijnde had moeten doorstaan. Men konde ook duidelijk zien, dat de angsten en schrikken ZijnEd. had doen vervallen."

2 De mededeelingen bij Van Doren-M. bl. 57-58 wijken niet af van die in Boelen-M. en Journaal.B. 
aan de vergaderden, welke redenen hen er toe geleid hadden om de Hollanders te beoorlogen en of zij overwogen hadden hun belang tot het sluiten van vrede. In stede van antwoord te geven op deze vragen naar den bekenden weg, merkte de radja van Nolot op, dat er nog drie regenten ontbraken en hierop gewacht moest worden. Nadat ook zij verschenen waren, herhaalde Groot zijn vragen; de gerokten bedachten zich eeu weinig en gaven toen het idiote antwoord, dat het om het geloof was! Intusschen hadden buiten de loods bewegingen van gewapenden plaats; eenige regenten trachtten ongemerkt de vergadering te verlaten. Groot scheen dit verdacht toe; Crozier en Ellinghuijzen konden nog beter de te denken gevende bewegingen waarnemen. "Volgens afspraak had een ieder de wapenen weggelegd, doch wij hadden niet lang gezeten of er vertoonden zich verscheidene met geweren eu klewangs gewapend; de luitenant Ellinghuijzen bemerkte weldra, dat er verraad was, en verwittigde den Kapt ${ }^{\mathrm{n}}$, dat het tijd was om te vertrekken, die egter de omstandigheden naauwkeuriger willende onderzoeken, weijgerde on te gaan" 1. Een der radja's drong er op aan nog te blijven zitten, daar hij een voorstel te doen had ${ }^{2}$. "Intusschen kwamen reeds gewapenden te voorschijn met scherpe vraagen en doordringende blikken. De Luit. Ellinghuijzen begon den Kapitein ernstig te vermanen om henen te gaan" 3. Toen de verwarring vermeerderde, stond eindelijk Groot op, zeggende, dat zij alles op schrift de vergadering zouden voorleggen, waarna hij met alleu, die hem hardden vergezeld, "benevens den Luitenant Christiaan", naar de Reygersbergen terugkeerde, "zonder iets van hetgeen zij opmerkten te laten blijken" " ${ }^{4}$. Dat terugkeeren ging echter niet zoo gemakkelijk als wel hieruit zou zijn op te maken. Ellinghuijsen en Crozier "namen den Overste onder den arm en gevolgd door Christiaansen, snelden zij eensklaps naar de sloep terug, waar zij zich als 't ware in lieten vallen" 5 . Zoo kwamen allen behouden aan boord "om $2 \frac{3}{4}$ uur" " ${ }^{6}$, "blijde zijnde dit gevaar ontkomen te zijn" ". Had men zich een oogenblik later bedacht, "dan was het wellicht met hen gedaan geweest, want juist op dat

1 Journaal $B$.

2 Van Doren-M., bl. 58.

3 Journaal-B.

4 Van Doren-M., bl. 58.

5 Boelen-M., bl. 261.

6 Journaal-B.

7 Journaal-Reygersbergen. 
moment verscheen Matulesia en, volgens zijne bevelen, moesten de Inlanders, zoodra $h i j$ zich vertoonde, op de onzen aanvallen en hen dood of levend aan hem overleveren" 1 . Commandant Groot deze gebeurtenissen naar Ambon rapporteerende, schreef uit verscheidene omstandigheden ten aanzien van de houding der vergaderden gemerkt te hebben: "dat zij het verraderlijke plan gesmeed hadden, om ons allen hier te vatten en naar alle waarschijnlijkheid te vermoorden, doch welk afschuwelijk plan door ons spoedig vertrek verijdeld is geworden".

Wie nu eindelijk ook tot zichzelf kon komen, was loods Christiaansen, "door den geleden angst en doorgestane mishandelingen geheel van streek" en "nu eens schreiende, dan weer lachende over het dek" loopende ${ }^{2}$. "Men had den ouden man van 67 jaren zoodanig gefolterd, dat hij bij zijn aan boord komst bijna kinds was en gedurig riep: Ik heb geleden als Christus onder Pontius Pilatus" "3.

Wat wilde toch Groot met de zelfs nu nog niet gestaakte correspondentie! "Om $3 \frac{1}{2}$ uur zonden alsnog een brief naar de wal. Ontvangen ten 6 uur een terug, welke dadelijk beantwoorden" ${ }^{+}$. Zelfs den $20^{\text {n }}$ verloopt in correspondentie! "Daar ik", zegt het scheepsjournaal ad $19 \mathrm{Juli}$, "den volgenden dag uit de correspondentie zag, dat hun zoeken was iemand van ons aan den wal te krijgen haalde ik, benevens de andere scheepen de witte vlag neder." Ja, maar pas om 4 uur in den namiddag, "Ontvangen", teekende het journaal van Boelen aan, "nog een brief van de negorij Saproa. Beantwoorde dezelve, dog ziende dat alles slegts uitstel en draaijen betekende, en men niets stellig tot de vreede scheen te willen, zo haaldeu wij om 4 uur in den namiddag de witte vlag neer. De Indianen, welke alsnog vertrouwlijk op het strand zaten, liepen daarop alle weg. Zonden een gewapende orangbaaij van boord om te kruisen. Om 4, $\frac{1}{2}$ uur werd aan de beide vlaggestokken op de wal een witte vlag halver stok geheschen. Men praaide om een brief te halen. Beantwoorde dezelve. Inspecteerde de manschappen tot de landing bestemd. Zette de gewone posten uit. Gedurende den nagt hoorden verscheidene sagueer trommen, en geblaas op de schulpen, vergezeld met schreeuwen."

1 Boelen-M., bl. 261. Verg. hierna bl. 697.

2 Boelen-M., bl. 261.

3 Journaal-B. - Verg. Ver Huell, dl. I, bl. 181.

4 Journaal-B. 


\section{HOOFDSTUK X.}

\section{Tweede tuchtiging van Hatawano: 21-31 Juli.}

Landing aan de kust van Hatawano: 21 Juli. - Hatawano nader ver. woest 22-26 Juli. - Vertrek van de Dispatch naar Haroekoe, 21 Juli. Opneming van gevluchte Ambonsche matrozen: 20 Juli. - Een spion van Nolot gevangen gezet en ontsnapt: 22-30 Juli. -- De Iris naar Noesa Laoet en terugkeer met den patih van Akoon: 26 Juli. - De Iris naar Ambon. - Een tweede opneming van gevluchten als matrozen: $30 \mathrm{Juli}$. - Terugkeer van de Dispatch van Hatawano: 31 Juli.

De witte vlaggen waren alzoo den $20^{\mathrm{n}}$ neergehaald met het voornemen den $21^{\mathrm{n}}$ een landing te doen. Terwijl men zich dien $20^{\mathrm{n}}$ onledig hield ter voorbereiding, " om met den dag een landing te kuunen entameren en de negorij te verbranden", gelijk Groot journaliseerde, werd hem nog met shet aanbreken van den $21^{n}$ door de rebellen een brief gezonden "van weinig consideratie en ongetekend". Ziehier wat verder op dien ochtend van den $21^{\mathrm{n}}$ geschiedde naar de mededeeling in Boelen's journaal: "Des nagts om $3 \frac{1}{2}$ uur maakten overal en alles tot de landing gereed, terwijl de grootste stilte in agt genomen werd; om 4 uur kwam er nog een brief aau boord, welke behelsde men wel stilstand van wapeneu dog geene vrede konde maken; inmiddels waaiden alsnog de witte vlaggen op het strand. Om $5 \frac{1}{2}$ uur debarqueerden de landingsgasten, gekommandeerd door 3 officieren. Die van de Iris en het schip the Dispatch debarqueerden ook. Vertrokken onder het gestadig vuren met het grof geschut van de drie schepen van boord ${ }^{1}$. Lande voor het centrum der vier negorijen ${ }^{2}$, onder het geven var enige decharches platonsgewijze. Intusschen vuurden de drie schepen gestadig tot dekking van het volk aan de wal, die hun best deeden om de huizen in den brand te steken." De landing had plaats "juist vóór het centrum van de vier negorijen" ". De divisie gaf eenige salvo's uit het geweer en marcheerde voorwaarts; toen, zegt het journaal,

1 Nl. de Reygersbergen, de Iris en de Dispatch.

2 "Der vier negorijen"; welke die zullen geweest zijn, blijkt uit dl. I, bl. 472-474. Hierna op bl. 693 zullen wij lezen van 5 negorijen.

${ }^{3}$ Boelen-M., bl. 261. Wat volgens het journaal van de Reygersbergen en van Boelen geschied is op 21 en $22 \mathrm{Juli}$, is in het memoriaal van Boelen, 
"vielen er eenige in wolfskuilen, dog wierden gelukkig niet bezeerd"; maar de Memorialist teekende aan 1: "Een geheele colonne van ons volk stortte daarin en, zonder ons kruisvuur, hadden zij door de massa Inlanders overvalleu en gemakkelijk afgemakt kuunen worden." - Voor het vuur der schepen en van de divisie weken de rebellen: de negorijen gingen in vlammen op. De geschiedenis liep nu spoedig ten einde. Om 9 uur des ochtends waren sloepen en manschappen weder aan boord; marinier Fr. Redelberg had het leven er bij verloren; twee matrozen bleken licht gekwetst ${ }^{2}$. De wind naar den zeekant zijnde, moesten de schepen tegen de vonken beschermd worden, terwijl de brand niet voldoende de negorijen bleek te verwoesten, ofschoon er van de schepen "van tijd tot tijd", deelt het journaal mede, kanonschoten afgingen om het blusschen te beletten. Dientengevolge ging in den namiddag nog een detachement ouder dekking van het geschut aan wal ten einde den brand verder aan te steken.

Commandant Groot liet het niet bij deze beschieting op 21 Juli; dat het hem met de afstraffing hooge ernst was geworden, blijkt nog uit de volgende aauteekeningen in het scheepsjournaal en in het journaal van Boelen:

22 Juli. Ten 9 ure werden eenige vrijwilligers, matrozen en Ambonsche burgers aan den wal gezonden om de negorijen en de vaartuigen te verbranden; tot dekking vuurden de beide schepen onophoudelijk ${ }^{3}$. Om half tien was het volk weder aan boord, het ging dus wel haastig. Toen haalden de schepen opnieuw een weinig van den wal voor het vliegen der vonken. Ten 3 ure in den achtermiddag werd een gewapende sloep van boord gezonden "om het visschen te beletten", zegt enkel het scheepsjournaal, doch het journaal-Boelen schrijft: "In de achtermiddag haalden wij van het strand met lang water de verloren wapenen door het volk", zonder verder in te lichten, hoe de wapenen verloren werden. Hier nog een mededeeling in het journaal van Boelen, die het scheepsjournaal niet

bl. 261-262, ten onrechte gememoreerd ad 22 en 23 Juli. De verdere data verspringen in het Memoriaal daardoor ook, totdat Boelen den $31^{\mathrm{n}}$ met de Iris naar Ambon vertrekt: Boelen-M., bl. 264-265; verg. hierna bl. 700. Over onjuiste data in Boelen-M., verg. hiervóór de noten 1 op bl. 678 en 681 .

1 Boelen-M., bl. 262.

2 Den $28^{\text {n }}$ Juli werd over boord gezet de gekwetste matroos J. van Teijlingen; ook eenige Amboneesche matrozen overleden aan hun wonden. Volgens den Chirurgijn-Majoor zagen de wonden er zeer leelijk en gevaarlijk uit, daar de rebellen als projectiel gebruikten bonken: muntstukken met den tweestuiversstempel erop en bestaande uit Japansch koper. Boelen-M., bl. 264. Verg. hiervóór dl. I, bl. 521, alinea 2.

${ }^{3}$ De Dispatch was vertrokken: zie bl. 692. 
inhoudt: "Om 3 uur in de agtermiddag vertrok ik met de groote orangbaaij om te kruisen. Ik liep digt langs de negerij Jahamao om dezelve op te nemen, dog kreeg weldra van daar eene algemeene decharge van bij de 20 geweerschoten. Ik beantwoordde dezelve met eenige schrootschoten uit de draaibassen. Voor de campong der Alfoeren twee jonken en twce orangbaais ziende, liep ik digt daaronder om dezelve met de draaijbassen te beschadigen, en kreeg weldra eenige geweerschoten, welke spoedig zwegen door de schooten met de draaijbassen, die ik deed. Daar hunne schooten alle over de chaloup gerigt waren, is er geen gekwest geworden."

Het scheepsjournaal vervolgt dan: "Daar de brand geene genoegsaame verwoesting had gemaakt, herhaalde ik wederom ten 4 uuren om de negorij te verbranden. Deeze brand was de sterkste, welke er geweest was." Het Boelen-jouruaal zegt hiervan: "Aan boord maakte men om $4 \frac{1}{2}$ uur allarm bij de stukkeu. De vrijwilligers gingen wederom onder de dekking van ons geschut naar de wal en verbrandde een groot gedeelte van de negorijen; de kerk en het huis van den Radja Nollot werd ook verbrand ${ }^{1}$. Den gehele nagt duurde dit vuur. Om 5 uur kwamen de vrijwilligers wederom aan boord. Geen was geblesseerd." 's Avonds ten elf uren begon de brand eerst te verminderen. "Ik was verplicht", zegt het scheepsjournaal, "gedurende die tijd volk op de raas bij de zijlen-te houden, en eenige putsen water in de marsen te hijsen, de brandspuit klaar te hebben, en het zwaar anker neer te winden om bij tijds te kunnen wegdrijven."

23 Juli ochtend: "Ten 8 uuren roeijde rond de hoek van de negorij en bevond dat aldaar nog verscheiden haisen stonden, als ook eenige vaartuigen, welke ik met adsistentie van de Iris ten $\frac{1}{2} 5$ uuren in brand liet steeken; doordien deeze negorij buiten het geschut der scheepen was liggende, had zich de vijand agter de muuren verschanst, waardoor twee Amboineezen gekwetst geraakten, als ook twee aan boord de Iris. Had met het schip weder gewerkt als de voorige dageu. De brand duurde tot 9 uuren." In Boelen's journaal staat hierover: " $\mathrm{Om} 3$ uur zonden de vrijwilligers onder dekking van ons geschut wederom naar de wal, welke het laatste van de 4 negorijen verbrande, alsmede alle de prauwen en vaartuigen vernietigde. Om 6 uur $\mathrm{kwam}$ het volk wederom aan boord. Dezelve hadden zig ditmaal zeer ver het land in gewaagd, waardoor

1 Ook bij Boelen-M., bl. 262-263. 
het corvet de Iris eene zwaar gekweste en wij twee zwaar gekweste Ambonesche burgers hadden."

24. Juli. "Daar in deeze negorij niets meer te verbranden viel", journaliseerde Groot, "verzijlde ik na de ankers geligd te hebben, voor de negerij Thamahoe en ankerde aldaar ten 10 uur... en zond den loods aan boord de Iris om mij te volgen .... Peilde de negorij in 't zuiden van mij en deeden 3 kanonschoten in dezelve, waardoor ik bemerkte, dat ik niet na genoeg was liggende om met goed gevolg gebruik van de batterij te maken."

25 Juli: "Om $\frac{1}{2} 9$ uuren ligten anker en verzijlde nader an de negorij; een groot rif daar uitstekende, was oorzaak men aldaar niet zo na meu wenschte te komen."

Met de kleine orembaai ging echter Boelen van boord om het rif van Ihamahoe op te nemen. Tot op een klein pistoolschotsafstand van den wal kon het fregat toen naderen en een zeer voordeelige positie innemen om de negorij te beschieten, waartoe hij op die plats een boei tot anduiding legde.

26 Juli: "Waren verpligt eenige schooten op de Negorij te doen, omdat de vijaud met het handgeweer op de troepen schoten."

Onder den loop dezer voorvallen vonden nog eenige andere bijzonderheden plaats, die vermeld behooren te worden. Door de Dispatch was aan de beschieting na den ochtend van hen $21^{\mathrm{n}}$ niet meer deelgenomen, omdat Groot het schip in den middag had gezonden naar Haroekoe, ten einde aan de autoriteiten te Ambon te doen weten "dat", zegt het journaal, "de onderhandeling was afgebroken, en ik was begouneu te ageeren". Op dat schip was overgeplaatst kadet ZouTMaN met vier gewapende matrozeu "om de vartuigen, welke ontmoet werden, te overmeesteren en vernielen". Daarentegen deed Groot van boord van de Dispatch komen vijftien Ambouecsche burgers, die naar de Reygersbergen overgingen.

Aan Inlauders had de Commaudant nog eenige ougezochte versterking gekregen den $20^{\mathrm{n}}$. Dien ochtend zag men namelijk een vaartuig naderen van den Ceramschen wal. Groot zond er terstond twee gewapende sloepen op af: "ten 1 uuren", verhaalt het journaal, "kwamen de chaloupen met het vaartuig aan boord, zijnde Amboineesche matroosen, welke van een Moorsche brik, liggende te Ceram Laut, gevlugt waaren, om de mishandeling der kapitein". In hoever dit waar was, viel niet uit te maken; wel bleken niet al die Amboneesche gasten te vertrouwen te zijn.

Den $22^{\mathrm{n}}$ Juli had de jol van de Iris een Inlander aan boord 
gebracht, die in den loop van den nacht met een kleine prauw van den wal was gekomen. Hij zeide thuis te behooren in een van de twee negorijen, gelegen binnen het retranchement van het fortje te Haroekoe, die dus wel de getrouwen van het Gouvernement moesten spelen ${ }^{1}$. Van Haroekoe was hij, luidde zijn verhaal, door een toeval op Saparoea gevangen genomen, doch hij werd nu gezonden door den radja van Nolot - lleze te tuchtigen of getuchtigd dien dag, blijkens het op bl. 691 medegedeelde - oin overste Groot te verzoeken : "dat hij uiet meer branden zou en met zijne schepen wegzeilen, dat hij, Radja van Nolot, dan beloofde met de vijf negorijen weder trouw te worden aan het Hollandsch gouvernement" ${ }^{2}$; ook vertelde hij, volgens het scheepsjournaal, dat een der kinderen van wijlen resident Van den Berg nog in leven zou zijn ${ }^{3}$. Commandant Groot liet zich echter met al die praatjes niet meer in; naar wij lazen, werden de negorijen in brand gestoken; de vriendelijke bode ging in de boeien. Inderdaad ontpopte hij zich, memoreert Boelen 4 , "in een slimmen en ondernemenden spion". Waaruit 's mans booze voornemens bleken, wordt nergens gezegd, wel echter was het onder de Ambonsche burgers aan boord niet pluis, hetgeen deels aan hun initiatief, doch ook aan dien bode werd geweten. "De te-vooren genoemde Inlander gaf ik", journaliseert Groot ad 26 Juli, "crimineel arrest uit hoofde mij voorkwam hij de inlandsche burgers een kwaden geest inboezemde, hoewel ik ook eenige suspitie had op een van hunne onderofficieren." 5 Het bleek weldra, dat de Amboneesche burgers meer voor dezen zendeling dan voor het Nederlandsche gezag gevoelden.

"In de eerste wagt", leest men in het journaal-Boelen, "zag de schildwagt onder het half dek dat een Amboneesch burger het slot wilde forceren van de boeijen van den Indiaanschen criminele arrestant, waarom ik den arrestant op het half dek in de ijzers zette en den Ambonees bij de schildwagt onder het half dek." In de dagwacht werd de Amboneesche burger ontsloten en de arrestant wederom bij den schildwacht gezet; maar in den nacht van den $29^{\mathrm{n}}$ op den $30^{\mathrm{n}}$ Juli slaagde de gevangen zendeling, door hulp van Amboneezen zich van zijn boeien los te maken en in zee te springen. Groot's journaal teekent hierover ad $29 \mathrm{Juli}$ 's nachts aan: "Ten $\frac{1}{2} \mathrm{l}$ uuren,

1 Verg. bl. 675. - Ik denk, dat nevens negorij Haroekoe zal bedoeld zijn Samet: verg. dl. I, bl. 465 , laatste alinea.

2 Boelen-M., bl. 262 , conform journaal-B.

s Verg. bl. 591-592.

4 Boelen-M., bl. 264; ook de in den tekst volgende mededeeling.

${ }^{5}$ Een korporaal werd daarom naar Ambon gezonden: zie bl. 698-699. 
terwijl de schildwagt bij het half uurs glas was, had de in de boeijen zijnde inlander zich daaruit weten te rukken en ontsprong of liever liet zich vallen uit de naastbij zijnde geschutspoort; de chaloupen altijd klaar hebbende liggen, ging dadelijk een derzelve met een officier van boord en snee hem de weg naar de wal af; dog vermoed, dat deeze Inlander zich bezeerd had en alzoo is verdronken, doordien hem bij het schip ook niet zeer spoedig hadden zien zwemmen." De hier bedoelde officier was Boelen, die daarover het volgende mededeelt ${ }^{1}:$ "I $\mathrm{Ik}$ had dien nacht de wacht en, leunende over de verschansing, keek ik uit naar het land, toen ik eensklaps een plof in het water hoorde, gevolgd door het alarm van den schildwacht. De gevangene was uit zijne boeien losgekomen en uit een der geschutpoorten aan bakboord in zee gesprongen. Ik sprong met eenige manschappen zoo vlug mogelijk in de, aan stuurboordzijde gelegene kleine orembaai, maar daar wij naar bakboord moesten omroeien, had de vluchteling een voorsprong, bovendien was het stik donker, zoodat wij niets konden bespeuren. Wij roeiden zoo snel mogelijk naar het strand en bleven er voor kruisen om den vlugteling den weg af te suijden. Na een half uur kruisen begreep ik, dat hij nu of-ontsnapt of door de haaien verscheurd zoude zijn en keerde naar boord terug. De Amboincezen werden vari nu af wat scherper in het oog gehouden."

Den dag te voreu, den $23^{\mathrm{n}}$ Juli, had de Reygersbergen nog een bezoek gekregen, dat evenmin vertrouwen wekte, hetzij dan terecht of ten onrechte. Den $26^{\mathrm{n}}$ was de Iris langs de oostkust van Saparoea zuidwaarts gezonden "ten einde het eiland Saparoea van dien kant te observeeren" 2. De observatie onzer schepen en het kruisen van hunne gewapende sloepen konden nochtans niet beletten, dat er tusschen Ceram en Saparoea gemeenschap werd onderhouden "en de vijandelijke Alfoeren in massa" overkwamen. De Iris was tot circa 'n mijl bij Noesa Laoet genaderd, toen van daar een prauw onder Hollandsche vlag naderde.

Dit eiland had terstoud het voorbeeld van Saparoea gevolgd en alzoo aan den opstand deelgenomen. Het blokhuis Beverwijk ${ }^{3}$ was door de rebellen afgeloopen; alleen een Europeesch korporaal, dien ik nochtans Brros genoemd vind, en twee Javaansche soldaten waren door twee regenten w. o. die van het nabijgelegen Sila,

1 Boelen-M., bl. 264.

2 Boelen-M., bl. 263.

3 Zie dl. I, bl. 476. 
die hen in het bosch verborgen hadden, van den dood gered; daarna was intusschen de korporaal door gebrek an voedsel bezweken ${ }^{1}$. Een der gangmakers van deze rebellie zou geweest zijn de ons reeds bekende ANтнопге Rнв́вок, het eerste hoofd onder Matulesi te Saparoea ${ }^{2}$. Hij gaf er de lakens uit en dwong, zoo luidt het verhaal, de hoofden tegeu wil en dank aan de rebellie deel te nemen. Onder hen behoorde het hoofd van het op de oostkust van Noesa Laoet gelegeu Akoon, patih Dominicus Thomas Tuwankotra 3. Patih Akoon heeft misschien berouw gekregen, zoodat toen hij de Iris op den $26^{\mathrm{n}}$ zag naderen, hij zich derwaarts begaf: dat was de prauw onder Hollandsche vlag ${ }^{4}$. Hij schijnt vrouw en kinderen achter gelaten te hebben, want wij lezen, dat Matulesi last gaf ze op te lichten en naar Boi over te brengen, gelijk geschiedde: hier werden ze ter dood veroordeeld, maar het vounis kwam niet tot uitvoering. Bij Van Doren leest men dan verder ${ }^{5}$ : "Zeker ooggetuige heeft ons verhaald, dat eenige dagen na het afloopen van het blokhuis Beverwijk Matulesia eene partij in de negorij Haria gaf, dat hij de vrouweu en de kinderen vau genoemden Patty dáár liet brengen, alleen met het doel, om deze weerlooze wezens te kunnen mishandelen. Men ving aan met de vrouwen te onteeren, doch haar zwager, dit ziende, werd in woede ontstoken en liep met ge. trokken zwaard naar de ellendelingen, die het feit begingen; doch hij werd dood gesteenigd, terwijl twee zijner slaven in hetzelfde lot deelden. De mishandelde vrouw en kinderen werden door de komst der voornoemde bodems in de nabijheid van Saparoea gered." Deze

: Ik ontleen het verhaal aan Van Doren-M. Op bl. 40 staat, dat het blokhuis "door ons vóór den opstand" was ontwapend en op bl. 61 van de redding "alleen" van korporaal en soldaten: dus was er wel bezetting? Een Europeesch korporaal, die heet Biroe, is evenzeer niet alledaagsch. Nevens den regent van Sila, noemt hij ook dien van Sosilisa, een naam, die niet thuis te brengen is; ik denk, dat bedoeld wordt Nalahia.

${ }^{2}$ Zie bl. 587. Ook ontleend aan Van Doren-M., bl. 61. - Boelen-M., bl. 263, gewaagt „van den kapitein Lucas" als „een andere benaming voor Thomas Matulesia”, dat ik voor een vergissing houd. - „Deze Lucas was eertijds een vrij burger uit de negorij Hatawana", teekent het journaal-Boelen op.

${ }^{3}$ Akoon, zie dl. I, bl. 476. Den naam van den patih geeft Van Doren-M., bl. 61 .

"Aldus Van Doren-M., bl. 41: "Inmiddels had Patti Akong van Noessa Laut, die zich bij den aanvang van den opstand, uit vrees voor Matulesia, in den stroom had laten medeslepen, op de verschijning van het oorlogsvaartuig de Iris zich onderworpen."

5 Van Doren-M., bl. 61. 
wraakoefening op de familie van den Patih wordt aldus bevestigd in het rapport-Porto:

Den $\mathrm{I}^{\mathrm{n}}$ (Augustus) omstreeks Io ure des avonds, kwamen radja Oelat Salimba, en Nicolaas Pattinasaranij met Thomas Matulesi en den kapitein van Ihamahoe, genaamd Aron, overeen, om de dochter van patih Akoon te brengen (naar Haria?) om te dansen en schande te brengen over het huis van Latumahina 1. De menschen van Porto en Haria doodden Johannes Tuwanakota, broeder van den patih van Akoon.

De patih van Akoon, aan boord van de Iris gekomen zijnde, deelde mede, dat de zeveu negorijen vau Noėsa Laoet trouw aan het Gouvernement wares; een vergadering harer radja's had hem naar het schip gezonden om hulp te vragen tegen de oproerlingeu, en speciaal tegen het invloedrijke hoofd ervan, die de bevolking en de radja's ringeloorde, "ofschoon zij, voor het meerendeel, het gouvernement in den grond van hun hart genegen waren" 2 . Akoon gaf ook inlichtingen over fort Duurstede te Saparoea, die ten slotte geenszins onjuist zijn gebleken. De kanounen waren er allen vernageld, de deuren met ijzeren bouten dichtgemaakt en overal zou de bodem met voetangels en wolfskuilen bedekt zijn. Overste Pool liep natuurlijk niet warm op de komst van dien nieuwen bondgenoot en meende hem "vooreerst in arrest te moeten houden". Zoo zeilde het schip naar de ligplaats der Reygersbergen terug: "'s Avonds ten half 9 uuren", staat er in het journaal ad 27 Juli van Groot, "kwam de Iris om de hoek van Hatowana en te tien uure bij mij ten anker, hebbende an boord de Radja van Akoon." Den volgenden ochtend ten 8 ure bracht Pool andermaal met den Radja een bezoek aan de Reygersbergen. "Laatstgemelde kwam", teekende Groot op den $28^{\mathrm{n}}$ in zijn journaal aan, "om vredesonderhandelingen te maken en zich uit naam der inwoners van gen ${ }^{\mathrm{d}}$ eyland aan het Goevernement te onderwerpen, verzoekende tot dekking van het eiland een schip of eene bezetting te mogen hebben tegen de aanvallen van de Sapoereesen. Ik konde die niet geven daar mijn macht alreeds te klijn was, om Saparoea te bevegten." Een paar dagen later benoemde de Commandant een commissie om den Patih nader uit te hooren over den toestand van Noesa Laoet en fort

1 Hoe deze naam hier te pas komt, weet ik niet.

2 Boelen-M., bl. 263, aan wien ook het in den tekst volgende ontleend is. 
Duurstede, ten einde daarnaar mede zijn maatregelen te kunnen nemen '. Patih Akoon deelde opnieuw mede:

dat van het oogenblik des opstands af het grootste gedeelte der bevolking van Noessa Lant er atkeerig van was, en dat zij alleen de komst van de Hollanders verbeidden; dat zoodra "de Iris" of eenig ander oorlogsvaartuig voor Noessa Laut kwam, zij eenparig besloten hadden, met hunne Regenten aan het hoofd, aan boord te komen en de kwaadwilligen over te leveren, daar zij zich thans alleen uit vrees voor de Saparoeanezen stil hielden;

dat er in het blokhuis "Beverwijk" slechts twee stukken geschut, waarvan de affuiten in stukken geslagen, aanwezig waren en het blokhuis geenszins bewaakt was;

dat het fort "Duurstede" goed in orde was, doch dat de stukken door Matulesia vernageld en de deuren met ijzeren beugels gesloten waren;

dat het strand met wolfskuilen was opgegraven, waarin borangs van bamboes en voetangels waren geplaatst;

eindelijk, dat er wapenen aan al de volkeren van Saparoea uitgedeeld waren.

Ook vertelde de Patih, dat tijdens het aan wal zijn van commandant Groot en de zijnen op den $19^{\text {n }}$ Juli ${ }^{2}$ "kapitein Lucas" zich in de nabijheid had bevonden en bevolen had, om, zoodra hij te voorschijn zoude zijn gekomen, al de Hollanders het hoofd af te slaan; kapitein Crozier moest echter gespaard worden, omdat de Engelschen als bondgeuooten werden beschouwd ${ }^{3}$.

Met den $26^{\text {n }}$ Juli had beschieting door onze schepen nog slechts incidenteel plaats. "Deeden", leest men op dien dag in Groot's journaal, "van tijd tot tijd een schot op de negorij, doordien er eenige inlauders, zich gewapend vertoonden. In den achtermiddag nam ik de negorij op; dezelve kwam mij zeer klijn voor en het scheen niet der moeite waardig, hieraan veel kruit te verspillen of volk te verliezen, daar ik zeker was dat deeze vol voetangels en wolfkuilen was en in het geheel niet meer dan uit 20 a 30 hutten en een of twee vaartuigen bestond, welke laatste ik doorschoot."

1 De Dispatch was van Haroekoe (zie bl. 692) weder den $31^{n}$ Juli bij de Reygersbergen ten anker gekomen; volgens Van Doren-M., bl. 62, „nadat” deze aankomst plaats had, werd de commissie benoemd; het verder in den tekst medegedeelde ook ontleend aan Van Doren-M., bl. 62-63.

2 Zie bl. 687-688.

s $\mathrm{Bij}$ Ver Huell, dl. I, bl. 190; het aldaar op bl. 189-190 medegedeelde komt met het in den tekst verhaalde voldoende overeen. 
27 Juli: "Deden eenige schoten op de negorij, wijl zich aldaar veel volk vertoonde."

In den avond van den $29^{\text {n }}$ Juli zag men de naar Haroekoe gezonden Dispatch ${ }^{1}$ weder naderen. Aangezien het plan bestond om tegen de hoofdplaats Saparoea te gaan ageeren, had Groot andermaal aan Pool last gegeven om naar Noesa Laoet terug te keeren, en daar te blijven kruisen, tot de Reygersbergen met de Dispatch ook derwaarts, maar op weg naar hoofdplaats Saparoea zoude zeilen, ten einde dan gezamenlijk de reis te vervolgen ${ }^{2}$. Hierin $\mathrm{kwam}$ echter in zoover verandering, dat de Iris bestemd werd voor een tocht naar Ambon met den last om van daar terug te keeren naar de golf van Saparoea ${ }^{3}$. De commandanten van de beide landsschepen verstonden zich niet goed: het was Zijner Majesteits oorlogsmarine versus de meer bescheiden Koloniale Marine of wel overste versus overste, zoodat Pool eens op zijn nommer gezet moest worden, meende Groot, door den commandant van het Ambonsch eskader. De lastgeving tot kruisen was toch nu alweer met het opperen van velerlei bezwaren beantwoord; Pool beweerde aan alles gebrek te hebben of gebrek te zullen krijgen: al die tegenspraak kon op den duur niet geduld worden ${ }^{4}$. "Ik verzock UwE.Gestr.", schreef toch deze aan Sloterdijk ${ }^{5}$, dat de Kapitein Luit. PooL stelliger orders bekomt: dat ZEd. ouder miju volstrekt kommando is, zoo lang de expeditie duurt, en ik, hier zijude, geeu kommando boven mij heb, daar ZEd. hierin difficulteiten maakt."

Met de Iris, die inderdaad aan alles groot gebrek had, werd ook weggezonden een Amboneesch korporaal, die verdacht werd de Am-.

1 Verg. bl. 697 , noot 1.

${ }^{2}$ "Ik gaf order aan den Kapt. $\mathrm{L}^{t}$. Pool om met de Iris zo lange tusschen Nousa Laut en Saparoua te kruisen tot ik met de Maria en de Dispatch op die hoogte kwam, om dan te saam naar het fort Duurstede te zijlen." Groot's journaal ad 28 Juli.

${ }^{3}$ Bij Boelen-M., bl. 264, leest men, dat overste Pool van commandant Groot den $30^{\mathrm{a}}$ Juli last kreeg om met de Iris naar Amboina te stevenen nen eenigen tijd te kruisen in de Banda Zee, ten einde den toevoer van wapenen en amunitie van de Zuidelijke eilanden, zooals Flores en Soembawa, te verhinderen". Jcurnaal ad 28 Juli.

4 In Groot's journaal ad 29 Juli leest men, dat een missive van kapitein Pool ontvangen werd, houdende dat hij niet meer dan voor 8 dagen water aan boord had: „daar hij meer zwarigheden maakte, resolveerde ik om meerdere redenen, dat schip naar Amboina te zenden, om zich van alles te voorzien". Groot verweet o. a. ook aan Pool, dat de Iris niet snel genoeg naar de Reygersbergen opwerkte: Van Doren-M., bl. 65 .

${ }^{5}$ Bij Van Doren-M., bl. 65. 
bonsche burgers aan boord op te ruien, makende, zegt het journaalBoelen, "door zijn woelig gedrag de andere burgers onwillig" ${ }^{1}$. Verder zou medegaan onze luitenant $t / z$ Boelen, die in last had twee veldstukken en andere krijgsbehoeften aan te vragen, benoodigd voor het doorzetten der expeditie; alles moest geladen worden in een voor dat doel te huren vaartuig, dat dan echter niet behoorde te zeilen naar de noord van Saparoea, doch naar de golf van dien naam, aangezien Groot vooruemens was zich mede derwarts te begeven voor de herovering van fort Duurstede ${ }^{2}$. Eindelijk schijnt nog met de Iris naar Ambou te zijn gebracht de patih van Akoon; zeker is het, dat dit hoofd derwaarts werd gezondeu, gelijk wij nader zulleu vernemen. Kapitein Pool mocht echter niet het anker lichten, alvorens de Dispatch terug was, daar dit schip wellicht brieven medebracht, waarop nog gediend zou kunneu worden. Tusschen het in 't gezicht krijgen van een zeilschip en de feitelijke aankomst kou echter nog een geruime tijd verloopen en zoo was het ook hier het geval.

Den $30^{\mathrm{n}}$ Juli des ochtends ten $\frac{1}{2} 11$ naderde weder een prauw van den Ceramschen wal. Een gewapende barkas en een orembaai werden er op afgezonden en uadat door dezen een geweerschot was gedaan, kwam de prauw binnen bereik. Ook de Inlanders daarin verklaarden te zijn vluchtelingen van een Moorsche brik, die door het Gouvernement was ingehuurd om van Timor koebeesteu te gaan halen ${ }^{3}$; door den kapitein en den stuurman zeer mishandeld wordende, hadden zij het plan gevormd naar Ambon te varen, doch toen zij de Reygersbergen ontwaarden, oordeelden zij het veiliger wegeus den oorlogstoestand zich derwarts te richten ${ }^{4}$. Groot voud geen aanleiding om aan de waarheid dezer mededeeling

1 Verg. Van Doren-M., bl. 65 en hiervóór bl. 693, noot 5.

2 Zie Boelen-M., bl. 265. De gedrukte mededeelingen stemmen over het geheel genomen met Groot's journaal. Over het gemis aan veldstukken, verg. hiervóór bl. 666 .

3 Verg. dl. I, bl. 522, alinea 3.

4 In Boelen's journaal wordt medegedeeld, dat het 8 ongewapende manschappen waren, die verbaalden, , dat zij tijdens het hijsen van de Hollandsche vlag op Amboina als matrozen uitgezeild waren met een Moorsche brik naar het eiland Ceram Laut; dat de Kapt ${ }^{\mathrm{n}}$. van dat schip aldaar door de inwoonders van dat eiland was gearresteerd geworden, omdat hij $\mathrm{i}$ an daar eenige goederon en amunitiën wilde wegsmokkelen, terwijl het volk aldaar onmenschelijk behandeld wierd; dat zij daarom met de prauw gevlugt waren om over Saproa naar Amboina te komen, terwijl zij als nog niets wisten van het oproer op de specerij-eilanden." 
te twijfelen, waarom hij al de acht man ook in zijn dienst nam, onder belofte zijnerzijds ze naar Ambon te laten teruggaan, wanneer fort Duurstede te Saparoea zou zijn vermeesterd ${ }^{1}$.

In den namiddag van den $30^{\mathrm{n}}$ Juli zond Groot een sloep naar de Dispatch, die door windstilte niet kon opwerken, "om de brieven te halen" ${ }^{2}$; de sloep bracht het teleurstellend antwoord, "dat op Haroeka nog geen tijding van Amboina was gekomen", zoodat nu de Iris bevel ontving de reis derwaarts te aanvaarden, gelijk den $31^{\mathrm{n}}$ Juli plaats vond, terwijl de Dispatch dien ochtend om 9 uur ten anker kwam. Met de aankomst van dit schip eindigt Groot's even roemlooze als nuttelooze werkzaamheid in de baai van Toehaha. Beide schepen stevenden naar fort Duurstede, teekent hij in zijn journaal ad 28 Juli op: "mijn plan als ook mijn order was, om zodra de Dispatch was teruggekomen, om dat fort in te neemen". Wanneer die order werd ontvangen, staat niet medegedeeld. De Dispatch bracht geen brieven mede, dus ook geen bevelen ${ }^{3}$. De herneming van fort Duurstede had, naar het voorkomt, het eerste punt van het programma moeten zijn. Hoe men er toe kwam én zijn krachten te verspillen met negorijen neer te branden, éu zijn zedelijk gezag prijs te geven door om het ophouden van den strijd te bidden, kan ik niet anders verklaren dan door de verregaande ongeschiktheid van het bestuur te Ambon, zoo burgerlijk als militair.

1 Verg. Van Doren-M., bl. 71.

2 Groot's journaal.

3 Toen de Iris bij Poeloe Pombo zich bevond op 31 Juli, kwam er van Haroekoe een orembaai aan boord, welke de brieven van Amboina bracht, die de reeds verzeilde Dispatch had moeten medenemen: Journaal-B. 


\section{HOOFDSTUK XI.}

\section{Fort Dunrstede hernomen: commandant Ellinghuịjzen : 3 Augustus-3 September.}

\footnotetext{
Voorbereiding tot den aanval op fort Duurstede: 1-2 Augustus. Inneming van Duurstede: 3 Augustus. - De dagen van 4-8 Augustus. Mei de bezetting van Duurstede is Saparoea niet onderworpen. - De Anna Maria brengt onvoldoende versterking, maar een militaire commissie voor opneming van het fort: 6-10 Augustus. - De Dispatch brengt evenzeer onvoldoende versterking: 7-15 Augustus. - De Anna Maria opnieuw met onvoldoende versterking van Ambon te Saparoea: 22 A ugustus. Heen- en wederzending van den patih van Akoon. - Eenige uittreksels uit Groot's journaal over het gevaarlijke van den toestand : 24-31 A ugustus. Komst van versterking met de Dispatch: 3 September. - Ellinghuijzen vervangen door Lisnet: 3 September.
}

Van nu af leeren wij commandant Groot met meer genoegen in deze expeditie kennen. Den $1^{\text {n }}$ Augustus was men "den Hoek van Hatowano", volgens het jouruaal voorbij gegaan, op reis naar hoofdplaats Saparoea; onderwijl maakte men alles aan boord gereed voor de landing aldaar en de beklimming van fort Duurstede. "Daar het te stil was geweest om door dat eiland en Saparoea door te lopen", werd gejournaliseerd over Noesa Laoet, ging men niet langs de west-, doch langs de oostzijde ervan. Ten $\frac{1}{4}$ vóór vieren in den namiddag van den $2^{\mathrm{n}}$ Augustus, ankerde men voor fort Duurstede. "Doordien er met handgeweer en draaijbassen uit het fort werd gevuurd" had de Reygersbergen een schot gedaan, "waarna het vuur verminderde". In de marsen waren door Groot den $1^{\text {n }}$ Augustus draaibassen en donderbussen geplaatst, ten einde het fort er mede te bestrijken, doch den volgenden dag "geen zwaar geschut in het fort bemerkende", werden ze er weder uitgeuomen eu in de sloepen geplaatst. Intusschen was die dag te ver gevorderd om nog een aanval te beginuen, zoodat hiermede werd gewacht tot den volgenden ochtend " om also met meer succes het fort te kunnen bestormen en den geheelen dag voorhanden te hebben, om het fort, genomen zijnde, te kunnen versterken tegen den volgenden nagt"; zoo werd ook het noodige bevolen "voor deu volgenden morgen om het schip in een 
goede positie te houden, en verrichtte alles wat ik konde denken mij den volgenden morgen te passe zoude komen". Het bevel over de landingsdivisie ontving de luitenant $t / z$ ElcrnghuiJzen; aan hem werden toegeroegd de luiteuants $t / z 2^{e}$ klasse Cochrus en Coops '

Zoo brak de $3^{\text {e }}$ Augustus aan. Dien dag zou de vermeestering van fort Duurstede beproefd worden; natuurlijk dat men erustigen wederstand verwachtte. Hiervan bleek nu echter zoo goed als niets; het fort was door de rebellen onbezet gelaten. Welke motieven hiervoor bij Matulesi gegolden hebben, zal wel niet zijn uit te maken; Van Rees doet het "geen hoog denkbeeld van zijue krijgskennis" geven ${ }^{2}$. Het feitelijke der vermeestering op den $3^{\mathrm{n}}$ vinden wij aldus in Groot's journaal aangeteekend:

Stilte en goed weer. Ten half vier uuren liet ik overal maken, de kooyen verschansen en alles aan boord tot het attakeeren van het fort in order brengen; bragten het werp agter uit aan $\mathrm{S}^{t}$ boord zijde, gaven elk een der gewapende manschappen een pakje patroonen, hun tegelijk belovende een halve maand gagie aan de drie eerste, welke in het fort kwamen en de vlag heesen; ten 5 uuren liet ik het volk in de vaartuigen gaan; het getal derzelve was een honderd en twintig man. Ten half 6 uuren staken dezelve van boord; op hetzelfde moment begon ik het fort te beschieten ${ }^{3}$, dog door het vuur van de Maria en de Dispatch retireerde de vijand, waardoor de landing zeer gemakkelijk wierd ${ }^{3}$. Zoodra de vaartuigen aan de wal kwamen, werd het fort met daartoe gemaakte stormladders beklommen door de matrozen Jan Smit, Nicolaas de Zeeuw en Johan Heer, welke dadelijk de vlag heeschen en door het andere volk wierd gevolgd, zodat ten 6 uuren de vlag reeds waaijde. Zoodra ik meester van het fort was, liet ik van de Dispatch vier ligte 6 it benevens de benoodigde amunitie halen, waarmede ten 7 uuren uit het fort wierd geschoten. Versterkte het fort nog met 2 ijzeren 6 u: van de Maria. Lieten alle de huizen rondom hetzelve in brand steken om daardoor het schieten uit de daken te beletten; het residentshuis, benevens verscheidenen burgerhuizen rondom en digt bij het fort staande, wierden een prooi der vlammen. Ik voorzag het fort van kruit en verdere amunitie, deed de stukken zo veel mooglijk ontnagelen en op de rolpaarden brengen,

1 Boelen-M., bl. 265.

2 Van Rees, bl. 103.

3 In Journaal-B. staat: "Om $4 \frac{1}{2}$ uur, terwijl de chaloupen van boord vertrokken, begonnen van onze schepen te vuuren". De Maria (verg. dl. I, bl. 517) was alzoo in deze dagen aangekomen. Waarom juist het vuur van dit schip en van de Dispatch de landing dekte, wordt niet opgehelderd: ik denk, dat die aan de zijden van het fort schoten. 
waartoe ik mijne kleine voorraad ten besten moest geven; ook voorzag ik hetzelve van victualy en water, daar er in het fort geen water was te krijgen, en de putten buiten hetzelve waaren alle gedempt ' ; nadat ik alles zooveel mooglijk had laten voorzien, dat tot defensie van het fort zoude dienen, zond ik de Dispatch naar Amboina om rapport te maken van de overwinning door ons behaald, en verzogt teffens zoo spoedig mooglijk om versterking van de $\mathrm{Com}^{\text {io }}$ en Comm. Het weinige volk, dat aan boord bleef, verdeelde ik in twee wagten en hield de batterij altijd gereed, om met een aanval der vijanden, daar dadelijk gebruik van te kunnen maken, waarom ook alle nachten de lantaarns wierden opgestoken. De Dispatch, welke ten II uuren onder zijl was gegaan, was verplicht wegens stilte weder ten anker te komen. Twee Amboineesche burgers zich te verre buiten het bereik van het geschut begeven hebbend, geraakten hun leven kwijt.

Boelen, vлn de verbranding van kampong Saparoea en het residentiehuis melding makende, herinnert er tevens aan, dat ook eevige prauwen een prooi der vlammen werden, waarna hij aldus vervolgt ${ }^{2}$ :

Onder deze vaartuigen bevond zich ook de groote orembaai van den heer Van den Berg, welk vaartuig, naar men beweerde, de directe aanleiding tot den opstand was geweest, daar de heer Van den Berg dit aan hem nieuw afgeleverde vaartuig niet naar den eisch had willen betalen ${ }^{3}$. Bij het bestormen van het fort had men weinig weerstand ontmoet, alleen bij het verbranden der gebouwen sneuvelden een paar van ons volk. Men vond in het fort vernagelde stukken van verschillend kaliber en een menigte kogels. Op verschillende plaatsen vond men sporen van den moord, die er had plaats gehad. Bloed tegen de wanden en op den bodem, doorstoken en bebloede kleedingstukken, o. a. de bebloede kornetsmuts van de Hollandsche dienstbode ${ }^{4}$ en kindersokjes, waarin de afgehakte voetjes nog staken. Ook vond men nog een briefje van de hand des heeren Van den Berg, van den volgenden inhoud: "Sergeant, Kom spoedig cito met 12 man mest scherp geladen om mij te verlossen. Alles is in oproer" (w. g.) van den Berg, Resident ${ }^{5}$. Gedurende den dag der inneming van het fort had men het zooveel mogelijk in staat van tegenweer gebracht en het noodige gedaan voor de rust en de voeding van de bezetting, die natuurlijk van alles, tot zelfs van drinkwater moest voorzien

1 Verg. dl. I, bl. 470.

2 Boelen-M., bl. 266-267.

3 Verg. bl. 600 , alinea 1 en bl. 580 , noot 2.

4 Het is mij anders niet bekend, dat de familie Van den Berg een Europeesche dienstbode bij zich had.

${ }^{5}$ Verg. bl. 582, noot 2. 
worden. Het fregat had men nu ook moeten gereed maken tegen een aanval van vijandelijke vaartuigen want, nu het grootste gedeelte van de equipage, het korps mariniers en de Amboineesche vrijwilligers als bezetting in het fort lagen, bleven er maar weinig verdedigers aan boord over. Niemand, tot zelfs de kommandant niet, verliet dan ook een oogenblik het dek, aan naar kooi gaan viel niet te denken, op het dek liggende moest men zijn nachtrust nemen en tevens gereed zijn om, op het geringste alarm van de schildwachten, hetzij van het fort of van boord, naar de wapens te grijpen en de batterij te bedienen. Met het fort waren de noodige alarmseinen vastgesteld. Lantaarns waren aan de bezetting mede gegeven om die te plaatsen op de uithoeken van het fort, opdat men van boord, buiten dat licht om, op den naderenden vijand zou kunnen vuren.

Ellinghuijzen werd commandant van het fort.

Over de drie volgeude dagen meldt Groot's journaal:

4 Augustus. Met den dag zeilde de Dispatch de baai uit. Zonden naar het fort eenige artillerie-goederen, om de daar zijnde rolpaarden te repareeren; hielden ons den ganschen dag onledig met het fort zooveel mooglijk te versterken; maakten gebruik van de bamboezen, die in de wolfkuilen om het fort stonden en makiten van dezelve voetangels; ook nam ik de ledige ffesschen, zoowel van mij als van de oficieren, sloegen dezelve aan stukken en wierpen ze om het fort, zijnde in al 860 stuks. Op het zien van eenige manschappen deeden wij van de batterij en van de Maria eenige schoten, waarop zij zich verwijderden. Voorzagen het fort voor 8 dagen victualij en van eenig water; gaven hun ledig vatwerk om water te kunnen vangen.

5 Augustus. Zonden weder eenige amunitie, kruit en patronen naar het fort, alwaar zij verplicht waren van tijd tot tijd op de negers te vuuren. Ik liet zulks door de Maria ook doen; en zij verwijderden zich.

6 Augustus. Ten 9 uuren kwam gewoonlijk de zeewind donr; men kon aan wederszijde schieten langs het fort, alwaar van tijd tot tijd canon- en geweerschooten werden gegeven om de vijandelijke piketten, die zich voor het zelve vertoonden. Zonden eenige victualy en amunitie naar het fort en begonnen de put leeg te maken.

7 Augustus. Met den dag wierd van het fort gepraaijd, dat aldaar een man was komen overlopen. Aan boord komende, bleek het een Javaan te zijn, die in dienst was geweest, en met het begin der revolte was gevangen gemaakt. Hij konde ons wijnig of niets van de macht des vijands of van hunne intentie mede- 
deelen, dan alleen, dat de Alfoeren van Ceram dit eiland hadden verlaten.

8 Augustus. Ontvangen uit het fort een draaijbas door den matroos Jan van Putten gevonden, welke bij die gelegenheid in een woltskuil is gevallen en geblesseerd aan boord gebragt. Ten II uren s'avonds wierd van het fort sein gedaan met vuurpijlen en twee lantaarns aan de uiterste zijde van het fort, hetwelk door een groot gejuig der vijanden wierd beantwoord. Dadelijk wierd daarop met schroot en van het schip met kogels geschoten en wel met dat gevolg, dat men zwaar gekerm der vijanden heeft gehoord en niet konde twijfelen of er waren onder hen eenige geblesseerden gekomen.

In den ochtend van dien $8^{n}$ had een stille plechtigheid plaats gevonden, waarvan de aanleiding gelegen was in een betreurenswaardig voorval van den vorigen dag, als volgt beschreven in Groot's journaal :

Ten 3 uuren het volk onder eene bezetting van buiten, aan de put werkende, had de Luit. van Guericke de onvoorzigtigheid zich zonder een genoegzame sterkte te ver buiten de post te verwijderen, waarvan het ongelukkig gevolg was, dat hij van agter een boom of muur door een vijandelijke kogel kwam te sneuvelen; een der matrozen, het lijk wenschende te sauveeren voor mishandeling, was verplicht door een sterke aanval hetzelve te moeten verlaaten, dog door een uittogt uit het fort wierd het lijk, hoewel niet geheel ongeschonden gesauveerd.

Het verhaal hierover van Boelen, tot wiens "beste vrienden" Guericke behoorde, luidt aldus ${ }^{1}$ :

De luitenant ter zee $2^{\text {de }}$ klasse F. H. van Guericke, die, na het nemen van het fort, dagelijks met een gedeelte manschappen naar den wal ging om den bij het fort zich bevindenden waterput op te ruimen en weder bruikbaar te maken, werd, daarmede bezig zijnde, uit een hinderlaag door den vijand beschoten, waarbij de kwartiermeester Nielsen gewond werd. Van Guericke, hierover in toorn ontstoken, liep met het geweer in de hand, - alle officieren en adelborsten waren gedurende den oorlog behalve met de sabel ook met een geweer gewapend - en gevolgd door slechts één matroos in de richting uit welke de schoten gevallen waren, maar ontving al spoedig een schot, dat hem ter aarde deed storten. Hij werd daarop besprongen door een aantal met klewangs gewapende Inlanders. De matroos kon tegen de overmacht niets uitrichten en moest een goed heenkomen zoeken, om niet zelf in

1 Boelen-M., bl. 267. 
de handen der vijanden te vallen. Op het hulpgeschreeuw van dien matroos rukte de luitenant ter zee $2^{\text {de }}$ klasse Cochius met eenige manschappen uit het fort, maar men vond slechts het hoofdlooze lijk van den ongelukkigen officier.

Het journaal der Reijgersbergen vervolgt dan op 8 Augustus aldus: "Ten $\frac{1}{2} 9$ uuren werd de Luit. van Guericke zonder eenige statie in het fort begraven, om geen oog aan den vijand, die om het fort was liggende, te geven, hoewel de gesneuvelde het bij zijn leven wel had verdiend, als zijnde een braaf en veel belovend officier."

De herneming van fort Duurstede bleek vooralsnog slechts van belang uit een oogpunt van moreelen indruk. Het gansche eiland toch bleef feitelijk in de macht der rebellen, zóó zeer, dat men zich zonder een goed gewapenden troep niet uit het fort dan wel derwaarts kon begeven. De Inlanders, ook natuurlijk bekend met het feit, dat de bezetting haar drinkwater moest verkrijgen uit de buiten de versterking gelegen put, hadden op dit punt voortdurend hun schietwapenen gericht; en deze put moest niet alleen gebruikt worden door de bezetting, maar ook door de op de reede liggende schepen, voor zoover deze aan het van de plaats van herkomst mede gebrachte water gebrek kregen. Soms ook kwamen de sloepen onverrichterzake terug, omdat de bron bleek opgedroogd; soms brachten ze slechts brak water mede ${ }^{1}$. Dan werd het uitzicht van de versterking in aanzienlijke mate belemmerd door bosch, uit de boomen waarvan bovendien werd geschoten; huizen, ook het staande gebleven muurgedeelte van de residentie-woning, bleken plaatsen, waarachter de "negers", zooals Groot's journaal ze noemt, of de "Indianen", zooals wij bij Ver Huell lezen, zich verscholen en het de onzen lastig maakten. Eindelijk trachtten de rebellen het fort zelf te benaderen door het opwerpen van verschansingen. Deze onzekere toestanden vorderden niet alleen aanhoudende afmattende waakzaamheid, doch tevens dagelijks, zij het ook kortstondig en met min of meer lange tusschenpoozen, dat er van het fort en van de Reygersbergen, soms ook van de Dispatch, werd geschoten en dat er uitvallen geschiedden, om den vijand ontzag in

1 Zoo leest men in Groot's journaal ad 6 September: „Ik was tegenwoordig als de gelegenheid het maar toe liet bij het dagelijksch water halen, doch konde zelden een volle vragt in de barkas krijgen, eensdeels omdat het vaartuig in de branding te veel leed, en ten andere omdat de put te weinig water opgaf." Zie ook o. a. bl. 726. 
te boezemen. Het geschut van het oorlogsschip was in den regel gericht op het land links en rechts langs Duurstede; echter ook weleens op het land voor den grooten weg; het ving eerst aan zich te doen hooren, als Duurstede het vuur had geopend, dan wel op een afgesproken, door den commandant der bezetting geplaatst sein ${ }^{1}$. Groot's journaal houdt over deze beschietingen dagelijksche mededeelingen in, die niet noodig zijn hier allen weder te geven. Wat Groot noodig had om krachtiger te kunnen optreden, was versterking aan middelen onder allerlei vormen. Boelen, met de Iris naar Ambon gevaren, had zijn commissie volbracht, echter na een weinig voorspoedige reis ${ }^{2}$. Hij was in den avond ten 8 ure van den $31^{n}$ Juli op Amboina gekomen en had dadelijk aan zijn boodschap gevolg gegeveu, waaronder de aantooning tot het zenden van hulp ${ }^{3}$. Den $5^{\mathrm{n}}$ Augustus was mede er aangekomen de den $4^{\mathrm{n}}$ te voren naar Ambon vertrokken, derwaarts gezonden Dispatch, ook al om op versterking aan te dringen 4 , tevens echter de verheugende tijding mede brengende van de bezetting van Duurstede.

Te Ambon scheen men de middelen, de geestkracht, de noodige orde in de behandeling der zaken te missen : commandant Groot verbeet zich van ergernis. Eindelijk werd er ingehuurd de Anna Maria, gezagvoerder Boll, die met water, victualie en kruit werd geladen; eerst echter den $6^{\text {n }}$ Augustus kon het vaartuig naar Saparoea onder zeil gaan ${ }^{5}$. Er was nog wel eenige ruimte op de Anna Maria voor aan Duurstede te zenden behoeften, maar die werd nu ingenomen door een commissie, bestaande uit een kapitein der artillerie, een dito van

1 Zoo leest men in Groot's journaal ad 5 September: „Ten half twaalf uure vielen verscheiden geweerschoten uit het fort, waarbij aan de Noordoostzijde een lantaarn wierd geplaatst, welke het afgesproken sein was om aan die zijde waar de lantaarn stond, te vuuren, waarom ik eenige kanonsehooten langs het fort liet doen, totdat de lantaarn was weggenomen."

2 Zie bl. 699 en 700. Den $31^{\mathrm{n}}$ Juli was de Iris tot de negorijen Rohomoni en Kabaoe genaderd, zonder nu wegens windstilte te kunnen vooruit komen. Hier kwamen aan Boelen een bezoek brengen kapitein Wilson van de voor Haroekoe liggende Zwaluw en luitenant Veerman. Boelen, zijn commissie spoedigst willende volbrengen, ging met deze heeren naar Haroekoe, waar hij van commandant Van Driel een prauw met 5 man ter beschikking kreeg om de reis te vervolgen. In den ochtend om 4 uur van 1 Augustus kwam hij aan den Pas, dien hij overging om met een andere prauw zich naar Ambon te doen scheppen. Journaal-B. - Alzoo een reis als die op $15 \mathrm{Juli}$ : bl. 675 .

3 Zie bl. 699 .

4 Verg. bl. 703 en 704.

5 Boelen-M., bl. 265 en Journaal-B. Het schip heet in dl. I, bl. 517 eenvoudig Anna. 
de infanterie en een luitenant van de genie, om het vermeesterde fort op te nemen! Wij zullen zoo dadelijk lezen, dat deze zending commandant Groot ten zeerste heeft verdroten. Het was dan ook een summum en doet mij denken aan een incident, tijdens de Belgische omwenteling, dat mijn vader beschreef, toen Mechelen in oproer verkeerde ${ }^{1}$. Den $10^{\text {n }}$ in den voormiddag tegen 11 uur liet de Anna Maria het anker voor Duurstede vallen, "inhebbende", teekent Groot aan, "water, victualy en amunitie, dog geen patronen of kogels, noch eenige versterking om het fort te bezetten, daar ik zoo uitdrukkelijk om had geschreven, maar wel een commissie van drie landofficieren om het fort te inspecteeren". De commandant van de Reygersbergen was blijkbaar diep geërgerd. In den voormiddag van den volgenden dag, dus 11 Augustus, ging Groot met de commissie naar het fort, "en", vervolgt het journaal, "stelde HunEd. in de gelegenheid om alles te bezigtigen, toonde hun de patronen, die ik verplicht ben geweest van journaal- en cardoespapier en grof kruit te maken, daar onder hun de Capt. Directeur van de Artillerie was, en also maakte ik hem bekend hoe noodzaakelijk patronen nodig waren; ook verzogt ik in 't bijzijn der andere offecieren aan den Kapt. der Infanterie, welke alhier als $\mathrm{Comm}^{t}$. zoude komen, om zo spoedig mooglijk volk te zenden, al waare het maar provisioneel 50 man, hetwelk ZijnEd. beloofde, zeggende overtuigd te zijn dit hoog nodig was" 2 . Den $12^{\mathrm{n}}$ Augustus keerde de Anna Maria met de commissie naar Ambon terug. "Maakten", laat het journaal over de werkzaamheden aan boord van de Reygersbergen daarop volgen, "zoo veel geweerpatronen als men papier daarvoor bij elkander konde krijgen en zonden dezelve naar het fort".

Wat niet door de Anna Maria op haar reis van Ambon had medegenomen kunnen worden, werd geladen in de Dispatch: alzoo mede voorzien van water, victualie, artillerie-behoeften. Het schip vertrok den $7^{\text {" }}$ naar de baai van Saparoea, doch deed tevens Haroekoe aan; Boelen keerde met dit schip naar Saparoea terug ${ }^{3}$. Haroekoe bereikte men den $9^{\text {n}}$. De Zwaluw lag er niet meer; zij was onder zeil naar Ternate en vervaugen door de Willoughby, kapitein Croiset. Twee kanounen met caissons, herkomstig van de Zwaluw, werden overgenomẹn; ook

1 Zie bl. 8, noot 16 der Bijlagen van mijn werk "De Belgische Omwenteling in Luik en Limburg" (1904).

2 De kapitein, die tot de commissie behoorde en als commandant terug zou komen, was Lisnet: zie bl. 714 .

s Verg. bl. 707. 
nam de Dispatch nog eenige affuiten op ${ }^{1}$. Den $10^{\mathrm{n}}$ zette men de reis naar Saparoea voort. Op het strand van Porto en Haria zag men gewapende en dreigende Inlanders, die op het lossen van eenige kanonschoten de vlucht namen. Om $7 \frac{1}{2}$ uur in den avond was men dwars van den hoek van Passer Poetih, dien men den $13^{n}$ in den voormiddag passeerde ${ }^{2}$. Ongunstig weer verhinderde ook nu een spoedige reis. Eerst in den avoud vau den $15^{\mathrm{n}} \mathrm{kwam}$ men bij Duurstede ten anker; Boelen keerde toen naar de Reygersbergen terug ${ }^{3}$.

Ook nu weder was Groot door deze nieuwe zending van de Dispatch geheel en al teleurgesteld; dadelijk zond hij "dit scheepje", gelijk het journaal ad 16 Augustus mededeelt, "weder naar Ambon terug om versterking".

Weinig had het bij deze reis naar Ambon gescheeld of de Dispatch was op de punt van Boi vergaan; ziehier wat er Boelen over mededeelt ${ }^{4}$ : "Mij werd last gegeven Kapitein Crossier met de barkas behulpzaam te zijn en te zorgen dat ziju schip zoo spoedig mogelijk in zee kwam. Reeds vroeg in den morgen kwam de Dispatch buiten de baai, doch daar finale windstilte bleef heerschen, werd het schip door den stroom naar den hoek van Booi gezet en met kracht naar het eiland Molana gedreven. De barkas kwam toen geducht te stade, want zonder haar assistentie zou de Dispatch op het uitstekende rif van dat eiland zijn gevallen. Door het manoeuvreeren met het schip, was ik met de barkas zoover om de kust in zee gerakt, dat ik van die gelegenheid wilde gebruik maken tot het omvaren van het eiland Molana, in de hoop teveus, dat ik tusschen dat eiland en de kust van Saparoea minder stroom zou ontmoeten om weder de baai te kunnen bereiken. Na dus het eiland Molana aan de westkust te zijn langs gevaren, besloot ik te gelijkertijd verkenning te nemen van de baai van Porto en Haria en roeide met de barkas tot voor de monding van die baai. Verder dan eene verkenning konde ik niet gaan, want ik had geeu order om die baai te bezoeken en het binnenvaren er van was ook niet geraden, daar de vijand, in massa zichtbaar, gereed stond mij aan te vallen en prauwen aan den wal werden klaar gemaakt, terwijl mijn vaartuig ongewapend en mijne manschappen zonder geweren waren. Deze vluchtige verkenning van de bai van Porto en Haria is mij later van pas ge-

1 Boelen-M., bl. 265. - Verg. dl. I, bl. 517.

2 Over dat Passer Poetih, juister wellicht Pasir Poetih, verg. bl. 663, noot 1.

s Er staat bij Boelen-M., bl. 265, gedrukt 13 Augustus; ik houd mij aan Groot's journaal. Verg. hiervóór de noot 3 op bl. 689.

4 Boelen-M., bl. 268. 
komen, toen de Maria Reygersbergen er binnen geloodst moest worden."

Den 22n Augustus was de Anna Maria van Ambon weder te Saparoea ${ }^{1}$. Groot had op verzoek van Ellinghuijzen, commandant van het fort (bl. 704), den $19^{\text {n }}$ gezonden "nog 6 matrozen en 8 Javanen naar het fort met pieken en enterbijlen tot versterking" en den $20^{\mathrm{n}}$, gelijk het journaal op die data memoreert, "eenig schrijfpapier naar de wal om patroonen te maken", zoodat de aankomst van de brik met verlangen werd te gemoet gezien; maar doodgeërgerd, teekent Groot aan: "Kregen van de brik 6 matrozen, behoorende tot de equipage van de Evertsen, dog met gemelde brik geen versterking, noch patroonen, noch eenige orders of instructien". Dat slot doet de deur dicht! Groot zond in den avond van den $24^{\mathrm{n}}$ Augustus Boelen weder naar de Anna Maria met last om versterking te Ambon te vragen; in den vroegen ochtend van den $25^{\mathrm{n}}$ ging hij onder zeil.

Met de Anna Maria was tevens van Ambon teruggekomen, zegt Groot's journaal ad 22 Augustus, "de patih van Akoon van Nousa Laut, welke bij mij aan boord werd gebragt, om hem verder bij gelegenheid derwaarts te doen transporteeren" ${ }^{2}$. Van Doren verhaalt ${ }^{3}$ : "Deze werd naar Saparoea met brieven afgezonden, om de welgezinden tot onderwerping te brengen en hen aan te sporen hunne hoofden uit te leveren. Spoedig wierd hij echter in hechtenis genomen en naar Noesa Laut terug gebragt". Ik vind echter in de officieele bescheiden ten deze niets anders, dan de mededeeling van Groot in het journaal ad 5 September, dat hij zond "naar de Dispatch de Patih van Akoon van Nousa laut om derwaards te worden getrausporteerd" en ad 6 September: "s Morgens te 3 uren zeilde de Dispatch naar Nousa laut". Den $8^{\mathrm{n}}$ September in den achtermiddag, verhaalt Groot's journaal van dien dag, kwam de Dispatch terug op de reede van Saparoea. Kapitein Crozier bracht daarop in den namiddag van dien $8^{\mathrm{n}}$ een bezoek aan het fort, medebrengende alweder den patih van Akoon. Hij verhaalde het volgende * : "Met het schip the Dispatch bij de negerij van Akoont komende, scheen mij alles vijandelijk gezind te zijn. Niettegenstaande zond ik de Patih met zijne brieven naar de wal; deze man bij zijue onderdanen komende, wierd met de allarmkreet ontvangen, zijue eigen voormalige vrienden vielen met klewans en pieken gewapend op hem aan en hadden die man

1 Verg. bl. 708.

2 Verg. bl. 699.

3 Van Doren-M., bl. 42.

4 Evenzeer in Groot's journaal en in Van Doren-M., bl. 42. 
zich niet ten spoedigste in de jol gered dan ware het met hem gedaan geweest, even als met zijn bediende, die den gruwelijken vijand in handen gevallen is ; zijn huis en andere bezittingen had men vernield."

Met de komst van schout-bij-nacht Buijskes als commissaris voor de Molukken, heeft deze "een nieuw huis van deugdzaam hout" voor hem "op kosten van al de negorijen van Noesa Laut" weer doen opbouwen; de Patih wordt daarna genoemd als radja van Nahalia op de Noordkust van het eiland; hij kreeg echter om mij onbekende redenen als zoodanig zijn ontslag. Toen gouverneurgeneraal Van der Capellen in 1824 te Saparoea kwam, legde deze hem toe een pensioen van $\mathrm{f} 25$ 's maands en ontving de man zijn rotan met knop terug, ten blijke, dat hij "onschuldig" ontslagen was '.

De bezetting van fort Duurstede, zoowel als de commandant van de Reygersbergen, had nog altijd moeilijke dagen door te staan, ten gevolge van gebrek aan alles, wat aan de verdediging en aan de uitvalleu kracht zou kunnen geven. De volgende uittreksels van Groot's journaal doen ons die moeilijkheden voldoende kennen:

24. Augustus: "Met den dag... een uitval uit het fort om eenige huizen te verbranden, die het gezicht wegnamen en waaragter de vijaud zig bedekte. Deden eenige schoten om de uitval te dekken."

26 Augustus: "Met het waterhalen werd door de vijand verscheiden geweerschooten op de buitenposten en op het volk bij de put gedaan, hetwelk mij verplichtte gebruik van het geschut te maken, hetwelk doorgaans het eenigste middel was, waarmede men de rebellen konde doen verwijderen."

28 Augustus: "Met den dag hadden eenige posten uitgezet aan de wal, om water te halen, waarbij de schiemausmant A. Loef in de rug zwaar wierd gekwetst; ook zagen destijds meer volk dan naar gewoonte, waarop ik somtijds als ook het fort een schot deed; ook liet ik het fort waarschuwen wel op hun hoede te zijn." Loef overleed aan boord, blijkens het journaal, den $13^{\text {u}}$ September en werd den $14^{\mathrm{n}}$ "met militaire honneurs aan den wal begraven".

29 Augustus. "In de hondenwagt wierden twee geweerschooten uit het fort gedaan, waarop ik het volk dadelijk bij de stukken liet komen. Ten 5 uuren de batterij goed kunnende zien, deed ik de stukken als naar gewoonte buksen ${ }^{2}$ om dadelijk langs het fort te

1 Van Doren-M., de noot op bl. 62. De mededeelingen bij dezen schrijver zijn ook hier zeer verward; in plaats van Nahalia staat er Natahia; dank Groot's journaal kan men ze hier of daar terecht brengen.

2 Buksen: richten??? 
kunnen schieten. Een quart voor 6 uuren met de schemering, hoorde ik een generaal geschreeuw en het handgeweer des vijands, welke een begin van aanval op het fort wilde maken. Dadelijk wicrd van het fort met handgeweer en een paar kanonschoten gevuurd, lietwelk door een continueel vuur van de Maria Reijgersbergen wierd beantwoord; het een en ander deed den vijand ten 9 uuren hunne retraite neemen, zo dat ten $\frac{1}{2} 10$ uuren het vuuren geeindigd was. Ik zond dadelijk een chaloep naar het fort om met de details bekend te worden. De Luit. Ellinghuizen, welke aldaar commandeerde, rapporteerde mij, dat de vijand gedurende den nagt zich stil agter de muuren van de residentie had verscholen en met den dag, zooals boven gemeld, den aanval deed; dat op het vuur zoowel van de Maria als van het fort, zijl. zich weder agter de muuren verschansten, waartegenop zij nu de stormladders zetten om zo in de batterij te schieten, dat zij tot tweemalen door het vuur vau het fregat daarvan moesten wijken, wijl dat vuur meest op die muur gericht was geweest; ZijnEd. heeft daarom enkel het vuur uit het handgeweer der Amboineezen gebruikt om in geval de vijand de couragie mogt hebben om het fort te bestormen, zich van het geschut, dat met schroot geladen was en het handgeweer der equipage te kunnen bedienen; dat ook het handgeweer der Amboneezen met het vuur van het fregat voldoende is geweest om hun in bedwang te houden; ZijnEd. eerst is begonnen met het geschut toen de vijand retourneerde, als' zijude toen buiten bereik van het haudgeweer; dat bij de eerste aanval de matrozen Brinkamp en J. Smit, daarna J. Bakker door de ambrasure doodelijk gewond zijn en een Ambonnees in de arm gekwetst is ${ }^{1}$; dat het getal der dooden en gekwetsten des vijands moeilijk is op te geven, doordien zij die wegsleepen, maar dat sommigen eenige hunner hebben zien wegdragen. Genoemde Luit. was bizonder over het gedrag der equipage en over de Amboineesche burgers te vreden en verzogt mij hun aan den Schout-bij-Nacht en gouverneur der Molukko's te recommandeeren; ook verzogt gem. Luitenant de gesneuvelden en gekwetsten te doen remplaceeren."

Groot liet het volk voor den boeg komen, las eenige zinsneden uit den brief voor, w. o. die betrekkelijk het sneuvelen van de drie matrozen, het aanmerkelijk getal dooden en gekwetsten, dat door

1 "Drie der knapste matrozen sneuvelden, en een Amboinsche korporaal gewond": Ver Huell, dl. I, bl. 192. Evenzoo in journaal-B. J. Smit had tot de eerste beklimmers van het fort behoord: zie bl. 702 hiervóór. 
den vijand was gekregen en dat allen in het fort zich goed hadden gedragen ${ }^{1}$. Naar aanleiding van Ellinghuijzen's verzoek om 6 vrijwilligers, boden zich allen aan, "zoodat ik verplicht was zelve te kiezen" 2. Dadelijk gingen alzoo 6 man naar het fort.

31 Augustus: "Met het waterhalen wierd de kwartiermeester N. Nielsen ${ }^{3}$ en een Amboneesch burger gekwetst."

1 September: "Met den dag buitenposten uit het fort gezet hebbende om water te halen, wierden die door den vijand aangevallen, 't welk een kleine schermutseling gaf, doch dat het geschut van het Fort en de Maria spoedig deed eindigen; bij deze gelegenheid wierd een Amboineesche burger gekwetst."

Terwijl Boelen te Ambon vertoefde 4, liep er het Noord-Amerikaansche schip Lady Paterson binuen, komende van Batavia met troepen ja, maar ook met de voor de Ambonsche autoriteiten beteekenende tijding, dat schout-bij-nacht Buijskes met een strijdmacht weldra zou nakomen; van de aangebrachte versterking kon de voor Saparoea bestemde Dispatch dadelijk wat medenemen. Zoo overigens nog weinig gedaan was geworden tot bestrijding van de rebellen, nu de komst van den Commissaris-Generaal in het vooruitzicht werd gesteld, meende men zooveel mogelijk alle vijandelijkheden tot diens optreden te moeten uitstellen.

Met het ondergaan der zon op den $2^{\text {u }}$ September zag men van de Reygersbergen de Dispatch tusschen Saparoea en Noesa Laoet doorzeilen, doch windstilte belette deze de reede van Saparoea te naderen. Eerst den $3^{\text {n }}$ slaagde het schip ten anker te komen; Boelen was aan boord met 130 man, 2 veldstukken ${ }^{5}$ en de daarvoor benoodigde ammunitie, zoomede 3 maanden levensmiddelen; echter bleek ook nu niet gedacht te ziju aan ammunitie voor het fort, zoodat de Reygersbergen nogmaals van haar kleinen voorraad aan Duurstede moest afstaan en derwaarts patronen zenden! De ontvangen hulp was overigens dringend noodig; gebrek dreigde aan spek, aan vleesch; de Ambonsche burgers waren niet langer te vertrouwen; zij toonden ontevredenheid en werden des nachts door de rebellen angezocht om over te loopen; de geweren der schepen waren in slechten start, de schroeven verloopen, de pannen ontstaald, zoodat

1 Journaal-B.

2 Groot's journaal.

3 Verg. bl. 705.

4 Verg. bl. 710.

5 Verg. bl. 666 en $699 .$. 
men alleen moest rekenen op de zeer goede geweren, die juist deze burgers in handen hadden ${ }^{1}$.

Dien $3^{\mathrm{n}}$ ontscheepten de troepen onder bevel van den kapitein LisNet. De ammunitie en de levensmiddelen werden toen en volgende dagen afgehaald. Den $5^{\mathrm{n}}$ werd de bezetting van Duurstede nog versterkt door de toezending van met de Dispatch aangekomen 12 Javanen en adelborst Nuijs ${ }^{2}$. Groot's gemoedsstemming over het beleid te Ambona teekende zich onwillekeurig bij het memoreeren van deze ontladingen. "Ontving", lees ik o. a. ad うे September, "uit de Dispatch 3000 patronen, sedert een maand van Amboina gevraagd en nu eerst gekomen, hoewel dit het vierde schip was dat van daar kwam; ook ontving ik eenige 12 ৫- en 16 \&-kogels".

De rebellen trachten de ontladingeu en inschepingen te verhinderen, zoodat Groot "eenige kanouschoten" op hen moest laten doen, gelijk het journaal ad 3 September aanteekende.

Lisnet werd nu commandant van het fort; onder hem werd er Boelen geplaatst voor "de directie" van de artillerie. De in het fort geplaatste equipage der schepen onder de luitenants $t / z$ Ellinghuijzen, Cochius, Coops en den adelborst Feldmaun ${ }^{3}$ keerden voor een deel naar de Reygersbergen terug; eenige manschappen en de Ambonsche burgers bleven ter beschikking van Lisnet, "daar voornoemde kapitein geen artilleristen bij zich had", meldt het journaal. Toen om $3 \frac{1}{2}$ uur Ellinghuijzen, na het commando van 't fort aan kapitein Lisnet te hebben overgegeven, aan boord stapte met het reeds vermelde personeel, werd hem evenals aan de andere officieren door overste Groot en de equipage een driewerf hoerah! toegebracht *. Ellinghuijzen bleef tot het einde vau den opstand in de Molukken werkzaam en voer ook op de Reygersbergen naar Java terug. Den $6^{\text {n }}$ Maart 1818 bereikte het schip de reede van Soerabaja, den $18^{\mathrm{n}}$ November d. a. v. die van Batavia. Hier eerst nam hij zijn afscheid, hetgeen Groot in zijn journaal aldus memoreerde: "Den $1^{\text {n }}$ December liet ik het volk opkomen om hun kemnis te geven, dat de $1^{\mathrm{e}}$ luitenant Ellinghuizen op zijn verzoek met het ontslag uit den dienst van boord ging; ik deed dit omdat deeze officier het commando over hen had gehad bij iedere landing in de Molukko's en gedurende de bezetting van het fort Duursteeden daar als commandant had geageerd."

1 Van Doren-M., bl. 69 en 70.

ฯ Journaal van de Reygersbergen.

s Verg. bl. $681,702,704$.

4 Journaal-B. 


\section{HOOFDSTUK XII.}

\section{Fort Duurstede onder commando van Lisnet: 3 September -9 0ctober.}

Schermutseling op 3 September. - Uitval op den $4^{\mathrm{n}}$. - Het vermanen tot onderwerping. - Gesprekken tussehen de rebellen en onze bezetting: 5 September. - Aanval van de rebellen in den nacht van 5-6 September. Ontdekking van geld en van een lijk, vermoedelijk van mevr. Van den Berg: 6 September. - Komst van de Anna Maria met versterking: 10 September. - Terug naar Ambon de patih van Akoon en luitenant Christiaansen: 12 September. - Javanen en Amboneezen der bezetting Duurstede schieten op elkander: 17 September. - Kleine uitvallen op 18-21 September. - Mislukte uitval op den 22n . De Anna Maria opnieuw te Saparoea: 28 September. - Vernieling der visschersvaartuigen. Bericht te Saparoea der aankomst van Buijskes te Ambon: 9 October.

Nadat men in Duurstede op den $3^{\text {n }}$ September eenigszins op orde was gekomen, werd besloten, om nog vóór het invallen van de duisternis een verkeuniug te doen, ten einde den overmoed der rebellen tegen te gaan. Het kwam tot een schermutseling; de muiters werden althans voor 't oogenblik uit de door hen opgeworpen verschansingen verjaagd met verlies van eenige dooden: de Reygersbergen deed toen ook, zegt het journaal, aan weerszijden van het fort een schot. Met de invallende duisternis keerde men naar het fort terug; op de borstwering bij de stukken bleef men echter bivakkeeren, "want de vijand scheen overmoedig in zijne voornemens te zijn" ${ }^{1}$.

Den volgenden ochtend, 4. September, met zonsopgang, begaf zich Boelen met eenige Ambonsche vrijwilligers buiten het fort om den toestand van het afgebrande residentiehuis op te nemen. Hij liet eenige ronde kijkgaten in de muren hakken, waarbij schildwachten werden geplaatst, om deu vijand waar te nemen. Menig oproerling is uit deze schietgaten, bij het heen en weer loopen tusschen de kampongs en hun hinderlagen, neergeschoten. De posten bij de kijkgaten gesteld, rukten des nachts het fort weer binnen, om den volgenden ochtend opnieuw derwaarts te gaan.

1 Boelen-M., bl. 271. Al het in den tekst verder verhaalde in dat memoriaal, bl. 271-273. 
Den ochtend, dat Boelen hiermede aanving, begon hij ook zijn artillerie-matrozen te oefenen in het omgaan met de beide binnen het fort gebrachte veldstukjes ${ }^{1}$; het uur was nog niet verstreken, of de matrozen toonden er zich voldoende in bedreven. Toen stelde hij kapitein Lisnet voor, om dadelijk na het middageten van het volk met die veldstukjes een uitval te doen, "daar de vijand niet zou verwachten, dat wij nog heden daarmede zouden komen opdagen". Lisnet verleende slechts noode zijn toestemming, maar eenmaal er zich vereenigd mede hebbende, gaf hij tevens bevel, dat de Ambonsche vrijwilligers aan den uitval zouden deelnemen om als tirailleurs op te treden en dat zij brandstoffen, bijlen, zagen zouden medenemen tot het opruimen van alles wat in den omtrek van het fort hinderlijk kon zijn voor het zien naderen van den vijand. Er was bij het fort van den vijand een "Zware benting", in de eerste plaats het doelwit van de onder Boelen in den achtermiddag uitrukkende honderd man met de twee stukken ${ }^{2}$. Ziehier hoe Boelen het verder gebeurde heeft gememoreerd:

Het rechtsche veldstuk liet ik op de flank aanrukken, wat zoo snel in zijn werk ging, dat het kanonvuur de achterzijde van de benting bestreek, voordat de vijand den tijd had daar langs heen te vluchten. De eerste schoten met schroot uit dat veldstuk brachten dan ook eene geweldige slachting onder hen te weeg. Toen rukten wij voort tot op het punt, waar de groote weg de laan kruist, aan welker uiteinde het grafmonument van een Engelsch Kapitein staat. Op dit kruispunt liet ik een der beide veldstukken post vatten tot het observeeren van den vijand en om te beletten dat die, terwijl wij voorwaarts drongen, ons in den rug viel. Het linksche stuk namen wij mede voorwaarts op den weg naar Porto en Haria. De Amboneezen tirailleerden voor ons uit, alles op hun weg vernielende.

De »Maria Reijgersbergen", die van onzen uitval kennis had gekregen, deed inmiddels het grof geschut spelen in de richting langs 'de westkust van het fort Duurstede, doch onze veldtocht met die twee veldstukjes ging met zoo'n snelheid voort, dat wij kans liepen voor de kanonkogels van het fregat te moeten retireeren, indien men daar aan boord niet bij tijds gemerkt had, dat wij ons reeds bevonden dáár, waar kort te voren de vijand geweest was en begrepen had, dat men het vuren moest staken. Nadat wij zooveel mogelijk ruimte gemaakt hadden door om te hakken en te vernielen al wat de belegeraars van het fort van nut kon zijn,

1 Verg. bl. 713:

2 Journaal-Reygersbergen, ad 4 September. 
en de vijand zich nergens meer vertoonde, gaf ik bevel om naar het fort terug te trekken. Doch de Amboineezen waren door den voorspoed op dezen tocht zóó opgewonden, dat zij mij als 't ware baden om verder voort te rukken. Ik was dus genoodzaakt den sergeant, hunnen aanvoerder, te zeggen dat ik daarvan thans moest afzien, omdat de munitie, die in een lederen zak medegevoerd werd verschoten was. De sergeant, dit vernemende, begreep dat van een verder voortrukken nu geen sprake kon zijn. Hij liet zijne manschappen retireeren, hun tevens toeroepende »obat passang soedi abis" (de munitie is verschoten). Deze woorden werden in het bosch door de Amboineezen elkander toegeroepen en natuurlijk ook verstaan door den vijand. In de eerste oogenblikken had ik op die onvoorzichtig geuite woorden geen acht geslagen en, terwijl wij met de veldstukken terug trokken, niet dadelijk opgemerkt, dat de vijand zich verzameld had en ons achterop trok. Wij hadden het bruggetje, dat wij met onzen krijgsmacht waren overgetrokken toen nog een goed eind voor ons, zoodat, had de vijand zijne operatie met meer stilte verricht, hij ons misschien had kunnen overrompelen; doch zijn krijgsgeschreeuw waarschuwde ons bij tijds. Ik had nog een paar schoten schroot voor het eene veldstuk, zoodat ik eensklaps aan mijn volk bevel gaf op nieuw op den vijand los te stormen. In woeste vaart renden wij op de muitelingen toe, die daardoor misschien meenden, dat zij door bovengemeld geroep misleid waren geworden, ten minste zij ņamen in verwarring de vlucht. Wij zonden hen nog twee schoten schroot na, maar toen was het ook zaak voor ons om terug te trekken, want nog slechts één schot kruit bevond zich in den lederen zak.

Ook nu bleek commandant Groot niet zijn illusie te hebben prijs gegeven, om door overreding de menschen tot inkeer te brengen. Althans Boelen had van hem brieven medegekregen, gericht aan de bevolking van Saparoea, waarin hij haar tot onderwerping vermaande, "indien zij niet al hunne bezittingen, huizen en vaartuigen verbrand en vernield wilden zien"; diegene, die Matulesi uitleverde, zou f 1000 ontvangen en die een hoofd van minderen rang uitleverde, f 500 ! Boelen deed deze op karakterloosheid der rebellen berekende stukken "zoo ver mogelijk van het fort" op bamboezen palen stellen ' ${ }^{1}$. Medio September bij een uitval, bleek ook nu het effect. "De door den Overste Groot en de Kapitein Lisnet onder de vijandeu verspreide proclamaties", schrijft de Memorialist 2, "vond men in een bundel aan een bamboestaak hangen, in het gezicht van het

\footnotetext{
1 Boelen-M., bl. 273.

${ }^{2}$ Boelen-M., bl. 276. - Verg. hierna bl. 724.
} 
fort, ten bewijze dat de opstandelingen met onze vermaningen den spot dreven."

"Het is wel te bejammeren", teekent hij nog ten deze aan ${ }^{1}$, "dat deze proclamaties zoo weinig invloed op de muitzieke bevolking hadden, want het was een bedroevend gezicht die mooie Kampongs met have eu goed te zien verbranden en vernielen. Vrouwen en kinderen, van woning beroofd, zwierven in de bosschen rond en het nachtelijk gehuil der honden, die 'savonds naar de verbrande Kampongs terugkeerden, verkondigde het gruwelijke van den oorlog."

De bevolking bleek zoo onnoozel niet dan dat het haar ontgaan zou, dat het betoonen door haar van neiging tot berouw een stukje kon zijn om ons er te doen inloopen. Op zekeren ochtend - het was den $6^{\mathrm{n}}$ September - had de commandant van het fort verzocht, dat Groot daar zou komen. Zich er ten 9 uren bevindende, kwam een rebel een brief brengen. Op een korten afstand van het fort genaderd, liet Lisnet de witte vlag plaatsen ten teeken, dat hij niet bevreesd behoefde te zijn; "doch", journaliseerde Groot, "ik ontdekte spoedig, dat het valsch was door de menigte manschappen, welke ik van hen gewapend zag en dat zy enkeld zochten eenigen van de onzen te omringen". Groot liet daarom aan de Reygersbergen weten, dat de batterij er gereed gehouden moest worden. Niettemin wilde hij persoonlijk toch de harten der boosdoeners vermurwen. Ziehier hoe dat toeging, volgens het journaal: "Eenige gewapende Amboneezen buiten het fort zijnde en hunne familiën onder de vijanden hebbende, trachtte ik de een en ander over te halen om over te loopen; onder die des vijands waren sommigen wel genegen, dog doordien zij alsdan verpligt waren vrouw en kinderen agter te laten en die door het Opperhoofd der rebellen het slagtoffer zoude worden, konden zij zulks niet doen. Ziende dat het geen ernst den vijand zijnde om eenige voorstellen te doen, liet ik uit het fort op hen vuren, waarop zij zich verwijderden."

In den ochtend van 5 September was de bezetting van het fort begonnen met de muren van het verbrande residentiehuis af te breken, waardoor een hinderlijke belemmering werd weggeruimd om den vijand op grooten afstand te kunnen gadeslaan. Geweerschoten wisselden zich; de Reygersbergen liet zich mede gelden; twee muiters lieten er het leven bij. In den achtermiddag kwam een massa rebellen opzetten met Matulesie, "zooals wij gisteren aan het hoofd gezien

1 Boelen-M., bl. 273. 
hadden" ${ }^{1}$, gekleed in een rooden rok, epauletten op de schouders, gewapend met een sleepsabel. Boelen memoreerde hier het volgende incident" 2 :

"Bij de schermutseling, die weder plaats greep, hielden de Amboineezen van een der voorposten een mondgesprek met den vijand. Een der Amboineezen had namelijk een broeder bij de muitelingen. Deze vermaande onzen Amboinees bij hem te komen. Onze Amboinees weigerde, maar waarschijnlijk aangetrokken door de banden des bloeảs, naderden de beide broeders elkander toch meer en meer, zoodat onze Amboinees, eer hij het zelf wist naast zijn broeder stond en omringd was door eene menigte oproerlingen, gewapend met geweer en klewang. Onze Amboinees smeekte zijn broeder tot inkeer te komen, doch deze zeide zijnen eed getrouw te moeten blijven, maar gaf deze verklaring met traneu in de oogen. Intusschen vroegen de andere opstandelingen onzen Amboinees: Zullen wij $u$ nu den kop afslaan? - Doe zooals gij wilt, maar welke voldoening zal u dit geven? was zijn antwoord. Inmiddels hadden gedurénde het gesprek der beide broeders onze voorposten voortdurend de muiters gewenkt om tot hen over te komen, doch deze schenen uiet den minsten lust daartoe te hebben. Met uitdagenden trots weigerden zij te komen. Vór dat onze Amboinees zijnen broeder verliet, gaf hij hem zijn hoed tot geschenk, welk bewijs van broederliefde ik hem vergoedde door hem een van mijne hoeden te geven" 3 .

In den nacht van denzelfden $5^{\mathrm{n}}$ op $\operatorname{den} 6^{\mathrm{n}}$, ten elf ure, half twaalf, had er een anval der rebellen op het fort plaats, waardoor bleek, hoe goed het was, dat de gansche bezetting des nachts achter de borstwering in de open lucht gelegerd lag: Lisnet, Boelen, Nuijs genoten de weelde van een balé-balé, maar allen bleven met de

\section{Journaal-B.}

2 Boelen-M., bl. 273-274.

3 Bij Van Doren-M., bl. 68, hetzelfde verhaal. In een noot aldaar staat aangeteekend: „De Ambonees beschouwt zijnen hoed als zijn voornaamste kleedingstuk, en zij zijn er zoo op gesteld, dat zij liever naakt zouden loopen dan eenen hoed missen. Het is een koddig gezigt de Ambonezen, wanneer het regent, naar de kerk te zien gaan, dan hebben zij allen hunnen hoed met hunnen zakdoek bedekt, om hem voor den regen te beveiligen. Eenen hoed aan eenen Ambonees geven, is een geschenk van groote waarde." - In den Compagniestijd zien wij hoofden vereerd "met een nieuwe hoed en goude geletterde hoedbant"; men houdt het er voor, dat de in 1618 opgetreden

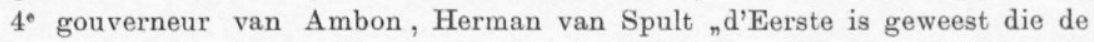
goude hoedbanden, off transen uitgedeelt hebben bestaande uijt goude Letteren, die dese woorden uijtmaakten: De Staten der Vereenigde Nederlanden Getrouw": Rumphius, dl. I, bl. 36 en 139. - Verg. hiervóór dl. I, bl. 477. 
sabel om, de patroontasch aan, het geladen geweer in de hand. $\mathrm{Nu}$ toch waren de rebellen er in geslaggd, dank de duisternis om ongemerkt tot dicht onder de muren te sluipen en de borstwering te beklimmen. "Er ontstond", verhaalt Boelen 1, "een woedend gevecht. Toen onze geweren afgeschoten waren, hadden wij geen tijd meer tot laden, maar moesten ons met sabel en bajonet verdedigen. Ten slotte werden de muitelingen toch teruggeworpen, en daar wij dadelijk lantaarns op de hoeken van het fort hadden geplaatst en vuurpijlen hadden afgeschoten als alarmsein voor het fregat ${ }^{2}$, verhaastten eenige goed gerichte kogels, aan beide kanten van het fort, door de Maria Reigersbergen afgezonden, 's vijand terugtocht. Wij hadden hieruit weder geleerd, dat wij niet genoeg op onze hoede konden zijn." Ten einde dergelijke verrassingen nog meer te bemoeilijken werden den volgenden dag opnieuw alle leege flesschen zoowel van boord als van het fort bij elkander gebracht, in stukken geslagen en de scherven om de borstwering gelegd ${ }^{3}$. De stoutmoedigheid des vijands verminderde echter niet. "De vijand beschoot ons voortdurend", schreef Boelen ${ }^{4}$, "en het was niet geraden het hoofd boven. de borstwering te steken. Twee mijner flinkste matrozen, die het gewaagd hadden over de borstwering naar den vijand uit te zien, betaalden deze ouvoorzichtigheid met hun leven."

Iederen dag werd er een verkenning in de omstreken van het fort gedaan, Den $6^{\mathrm{n}}$ " vonden mijue matrozen", memoreert Boelen ${ }^{5}$, "in de verbrande huizen drie zakken en een kist met kopergeld ter waarde van 500 ropijen." "Ook", leest men in Boelen's journaal, trouwens in overeenstemming met het memoriaal, "vonden wij een lijk zonder hoofd, het welk ons toescheen de vrouw van den Resident te zijn ${ }^{6}$ an het kleed, doch nauwelijks hadden den linker arm bloot gehad of ik liet het zelve wederom bedekken; het ligchaam, dat in het droge zand begraven was, was uitgedroogd." Het geld werd den commandant afgedragen, en het lijk behoorlijk begraven.

Toen den $3^{\mathrm{n}}$ September de Dispatch versterking had aangebracht ?

${ }^{1}$ In Boelen-M., bl. 274, staat in den nacht van den $6^{\text {n }}$, hetgeen niet juist is, blijkens het journaal van Groot en van Boelen.

Verg. bl. 707, noot 1 .

${ }^{3}$ Boelen-M., bl. 275. - Verg. hiervóór bl. 704 ad 4 Augustus.

'Boelen-M., bl. 275.

5 Boelen-M., bl. 274.

${ }^{6}$ Dus niet van Sriba Ornek, zooals Ver Huell mededeelt: Ver Huell, dl. I, bl. 195 .

7 Zie bl. 713. 
ontving commandant Groot tevens van Ambon bevel om dit schip, zoomede de nog met artilleristen te zenden brik Arna Maria op de noordkust van Saparoea te laten kruisen, sten einde zooveel mogelijk de correspondentie van den vijand te beletten", zooals het jourual ad 10 September memoreert ". Dit bevel van gouverneur Van Middelkoop schijnt weer verkeerd te zijn geweest, daar de Dispalck een deel van of al zijn geschut ann fort Duurstede had afgestaan ${ }^{2}$. Kapitein Lisnet lichtte echter Groot in, dat met de brik twee 8 ponders zoulen komen, waarom in afwachting daarvan de Dispatek alvast nas Noesa Laoet werd gezonden, ten einde den patih van Akoon daar an land te zetten en vervolgens terug te komen. Gelik wij hierworen lazen, lukte dit aan land zetten niet, zoodat de Dispaleh met den Patih onverrichterzake terugkwam ${ }^{3}$. Windelijk verscheen den $10^{\mathrm{n}}$ September de lang verwachte Ama Maria ter reede. "Ten 6 unren hoorde een kanonsehot nit zee; kort daarop werd van het fort sein voor een schip gedaan; konde van een brik over de boomen de toppen zien. Dasr ik veronderstelde de brik adsistentie noodig had, zond ik twce chaloupen derwarts; ten 9 nuren kwam de brik Anna ten anker" 4 . Ze had ann boord den luitenant der artillerie Krscer, 48 artilleristen, 12 infanteristen sen twee oude veldstukken, alsmede eenige victualie voor de Maria" " Groot deelt verder mede: "Debarqueerde de troepen dadelijk en loste de brik, die geen ammunitie voor het fort hebbende, was ik verpligt twee ligte $6 \mathbb{\leftrightarrow}$ stukken van het fort aan boord der Dispatch te embarqueren en twee zware $6 \overparen{\leftrightarrow}$ van de Maria naar het fort te brengen."

1 De lastgeving bij de aankomst van de Dispatch op 3 September bij Van Doren-M., bl. 70. De Anna Maria was den 25en Augustus naar Ambon vertrokken; bl. 710 .

2 "hoewel ZEd. bewust moest zijn", leest men bij Van Doren-M., bl. 70, over het bevel van Van Middelkoop, ndat het geschut van the Dispatch aan land was gebragt en tot verdediging van het fort Duurstede diende en tot nog toe niet door ander vervangen was".

${ }^{3}$ Zie bl. 710. Van Doren-M., bl. 42, deelt mede, dat het kanonvuur van de Dispatch verhinderde het vermoorden van den patih van Akoon - verg. bl. 710-711 hiervóór - waaruit volgt, dat het sehip niet al zijn geschut aan Duurstede had afgestaan.

4 Journaal-Groot.

${ }_{5}$ Journaal-Groot, wat de aanhaling betreft. Het aantal militairen bij Van Doren-M., bl. 70. - Boelen-M., bl. 275, gewaagt van ${ }_{n} 76$ man Europeesche artilleristen en Javaansche infanteristen met een dertigtal vrouwen en kinderen, zonder welke de Javaansche soldaten hun land ongaarne verlaten". - Boelen-M. schrijft, met afwijking van het Journaal en van Ver Huell, dl. I, bl. 195, Kesseler. 
Het is duidelijk genoeg, dat Groot steeds ontevreden blijft over het beleid van het bestuur te Ambon. Met de stukken gingen tevens van het fort naar de Dispatch: "een cadet, en 6 man tot zijne adsistentie"; den $12^{\text {n }}$ zeilde het schip de baai weer uit "om benoorden Saparoea te kruisen" ${ }^{1}$.

Terwijl nu Kesler als commandant van de artillerie optrad, ging Boelen terug naar de Reygersbergen en wel met 15 matrozen en 7 Javanen, zoodat er zich nu aan officieren in het fort bevonden: "een Kapitein en twee Luitenants van de Infanterie en een Luitenant van de Artillerie" 2. Aan de lastgeving, dat ook de brik Anna Maria ten noorden van Saparoea zou blijven kruisen, meende, naar het schijnt, Groot geen gevolg te kunnen geven. "Daar het zeer noodzakelijk werd geacht, de correspoudentie over zee tusschen Saparoea en Amboina ongehinderd te houden, werd de particuliere brik Anna tot dat einde bestemd, om tevens de benoodigde amunitie, vivres, enz. waar Saparoea over te voeren" " Den $11^{\mathrm{n}}$ September deed Groot, volgens zijn journaal, op de brik, die naar Ambon den volgenden dag zou zeilen, inschepen: "den oud-luit. Christiaans, den tolk Hoed, de geblesseerde Amboneesche burgers en 8 Amboineesche matroozen, welke voor Hataewana aan boord waren gekomen, de patti van Alkoen, een der adelborsten Oosthuyzen in commissie en den $3^{\mathrm{n}}$ Chirurgijn voor surveillance der geblesseerden" 4 . Alzoo ging de patih van Akoon overrichterzake opnieuw naar Ambon; ook luitenant-loods Christiannsen. Hij had Groot bij meer dan een gelegenheid gewichtige diensten bewezen; een eervolle vermelding werd hem toegekend; te Ambon genoot hij dus ook een goede ontvangst. De teruggezonden 8 matrozen waren die, welke door Groot, blijkens het hiernevens medegedeelde 5, werden aangenomen onder belofte van te mogen teruggaan na de vermeestering van Duurstede. Van Doren deelt tevens mede ${ }^{6}$, dat nu op last van Groot teruggingen "de Ambonsche roeijers, die hij van Amboina had medegenomen, en die zich bij verschillende gelegenheden goed

\footnotetext{
1 Beide aanhalingen uit het journaal-Groot.

2 De herplaatsing op de Reygersbergen in Groot's journaal; de aangehaalde woorden bij Boelen-M., bl. 275.

3 Van Doren-M., bl. 71. - 't Kan ook wel zijn, dat Groot handelde, krachtens een nader ontvangen instructie.

4 Den $12^{\mathrm{n}}$ vóór het vertrek werden nog 2 gekwetste Javanen op de brik gebracht: Groot's journaal. De chirurgïn heette WinkelHoek: BoelenM., bl. 276.

${ }^{5}$ Zie bl. 699-700.

6 Van Doren-M., bl. 71-72. - Verg. hiervóór bl. 660.
} 
gedragen hadden, hun verlangen te kennen gegeven hebbende, om naar hunne familie terug te keeren". In het algemeen was Groot, hoe ontstemd ook over de wijze, waarop men hem van Ambon gesteund had, zeer tevreden over de wijze, waarop het personeel zijn plicht had betracht. "Ik kan UEd. de verzekering geven", rapporteerde hij toch den commandant Sloterdijk ${ }^{1}$, "dat zij allen leeuwenmoed aan den dag hebben gelegd en dat bij den laatsten aanval niemand hoegenaamd een voet breed van zijne plaats is geweken, dat overal, zoowel in het fort als aan boord de grootste bedaardheid en geene de minste confusie heeft plaats gehad en dat men door het goed gedrag, door een ieder getoond, het behoud van het fort te danken heeft; zoodat ik de vrijheid neem UEd. te verzoeken de officieren en manschappen van de land-en zeemagt, onder mijne bevelen, aan zijne Excellentie den Schout-bij-Nacht te recommandeeren."

Den $17^{\text {n }}$ September had er een ongelukkig misverstand plaats, waarvan de verantwoordelijkheid valt, naar het voorkomt, op den commandant van Duurstede, kapitein Lisnet. Dertig Amboneesche burgers waren op zijn uitnoodiging vrijwillig het fort uitgetrokken om in stilte het residentie-huis rond te gaan, ten einde te trachten rebellen op te ligten. De Javaansche schildwachten, van deze excursie niet op de hoogte gebracht, vuurden op de Amboneezen, die van hun kant, nogsl zonderling, terugschoten. Het misverstand werd weliswas ten spoedigste opgehelderd, doch de Amboneezen zagen er een kwasd woortecken in en wilden alzoo niet den tocht opnienw wagen. Volgens Boelen's memorial kreeg wen sen pan gewonden ${ }^{\text {* }}$, wolgens Boelen's journal skreeg een Ambonees een sehot door de broek, doch geen is geblesserd geworlen ${ }^{* *}$. Uit dergelijke incidenten ksn men witnemend opmaken, he slecht er in het slgemen werd greschoten.

Den $18^{\circ}$ Septenber on half twaslf in den ochtend deden de Amboneesen ran het fort een attval en verjoegen de rebellen met een rebellenhoofd, sop een lediksat liggrnde" ${ }^{*}$, onder achterlating van een kanownetje, "n $\frac{s}{4}$ ponder, wasmede werd geschoten en dat, naar men sien kon, op Saparvea was gegoten 1 Ben ea ander brachten te ousen wase het fort.

Den 19a wend wan het fort en door de Reygerberyes onder-

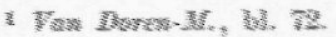

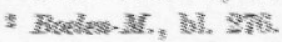

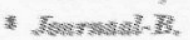


steunde uitval gedaan, om de verschansingen des vijands, die steeds meer naderden, te vernietigen en eenige hinderlijke boomen om te kappen, daar hieruit steeds op de bezetting werd geschoten.

Den $30^{\mathrm{n}}$ in den avond zag men uit het fort, dat de rebellen een pak brieven op een stok tusschen eenige bamboezen plantten. Nieuwsgierig ging men er onzerzijds henen, om te weten, wat dat beteekende. Het bleken de brieven te zijn door kapitein Lisnet verspreid, waarin hij verzekerd had, dat ieder, die met vrouw en kinderen wilde terugkeeren naar het fort, daar bescherming zoude vinden ${ }^{1}$.

De $21^{\mathrm{e}}$ was een Zondag. Van het fort zag men de rebellen een tafel met verscheidene banken er om plaatsen, ten einde er kerk te houden, gelijk zij lieten weten. "De Kapitein Lisnet nam daarmede geeue consideratie en liet met handgeweer en kanon wakker op hen vuren; waarop zij genoodzaakt werden, om te vlugten" 2 .

Kapitein Lisnet had het plan gevormd om den $22^{\mathrm{n}}$ September weder eens een flinken uitval te doen, gelijk aan dien op den $4^{\text {n }}$ door Boelen bewerkstelligd 3. Het hoofddoel was ook nu om 's vijands verschansingen van koraalsteen, die te zeer kneldeu, te vernielen, zoomede geboomte weg te ruimen. Om 6 uur in den ochtend trok Lisnet uit met 3 officieren, 150 man ${ }^{4}$ en 3 veldstukken ${ }^{5}$. Een half uur te voren was van de Reygersbergen Boelen met den bootsman Wigtbal en 24 matrozen naar het fort gezonden, om intusschen de artillerie te bedienen. Onder het door Boelen bevolen kanonvuur met schroot, marcheerde Lisnet, tot hij bij de borstweringen een hardnekkigen tegenstand van de rebellen ondervond, die zich in grooten getale hadden verschanst achter opgeworpen batterijen van steen en aarde. Er stroomen daar bovendien een paar beken, waarover tijdeus Boelen's tocht op den $4^{\mathrm{n}}$ nog drie bruggen lagen; toenmaals had men er een goed gebruik van gemaakt, de rebellen hadden ze echter nu verbraud. Hierdoor kon men het veldgeschut niet achter de batterijen des vijands brengen. In minder dan geen tijd had men van onze zijde 11 gewonden. Van het plan tot het omkappen van boomen kwam niets; men

1 Verg. bl. 717-718.

2 Journaal-B.

s Zie bl. 716. De door mij gegeven uiteenzetting ontleend aan Journaal-B.

4 In Boelen-.M, bl. 276, leest men 130 man.

- Ver Huell, dl. I, bl. 195-196, van dezen uitval verhalende, schrijft 2 veldstukken. 


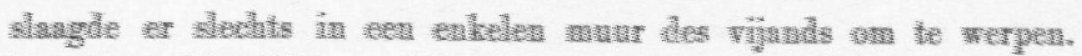

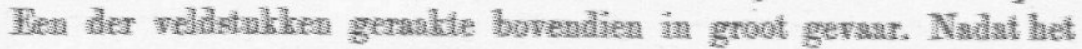
waur had gegerre, sprong em groote menigte wan uchter een borstwering te wourdhjy on es jich wan te wermeesteren. In swar

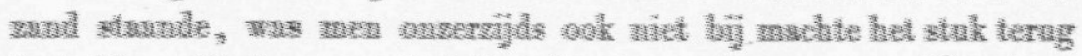
te trekken. Bocken, wan het fort den toestaud warnemende, whoot cen achtponder met schnod sf, wardor de rebellev terugdeinsden en men wusersijds gelegeabeid luweg net bebalp van wit het fort

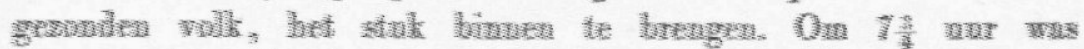
de excurtie weder in het fort terug. Boclen had wan de batteril met swara geschnt jour bet bosch doen schieten en de Feygergheryes. toonde with nixt winder, dow 28 seboten te doen afgan. Van het

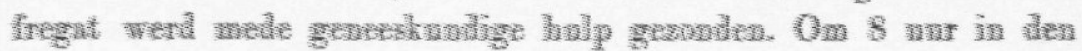

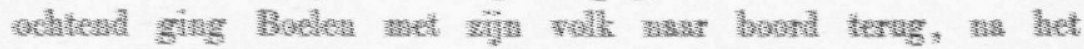
commando der adtllerie weer te hebben awergegeren an den luite-

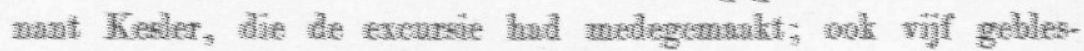
serrile Jawankebe soldaten menden met het oog op de werpleging

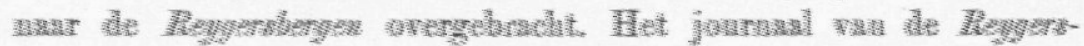

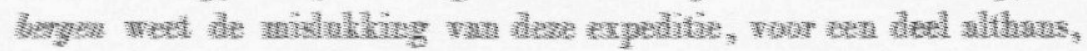

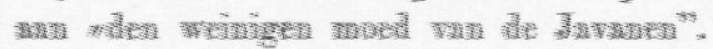

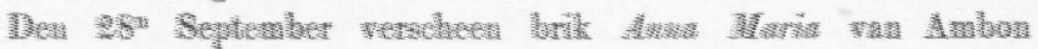
weder ter reede wan Sryanoen ${ }^{*}$, hefts door de rebellen wan den smilhoek der baai met eenige geweerschoten begroet; zij liet het anker om $7 \frac{1}{2}$ uur in den ochtend vallen. De chirurgyn WInkelhoek, die de gewonden op reis had begeleid ${ }^{2}$, kwam op dezen bodem mede terug; ook werd het aantal militairen versterkt met de komst van den cadet $1^{\mathrm{e}}$ klasse 'T HooFT; eindelijk werden nog aangevoerd ammunitie en levensmiddelen. Dat de bezetting van het fort niet in allen deele toewijdend was, blijkt nog wel hieruit, dat toen den $1^{\mathrm{n}}$ October de brik de reis opnieuw naar Ambon makte met een bezending gekwetsten en den chirurgyn, tevens medegingen $4 \mathrm{Am}$ bonsche burgers, "welke onwillig waren langer te dienen", luidt het in het journaal van Groot. Boelen meldt in zijn journaal, dat zij in den voormidulag als arrestanten aan boord werden gezonden, doordien zij "in de laatste nagt eenige oproerigheden gepleegd hadden"; de mogelijkheid is niet uitgesloten, dat men de menschen langer wilde aanhouden, dan waartoe zij verplicht waren.

1 Verg. bl. 722.

2 Zie bl. 722 . 
Den $2^{\text {n }}$ October plaatste Groot den cadet $1^{\mathrm{e}}$ klasse Zourman op het fort, ter aflossing van collega Nuijs, "welke het opzigt van de manschappen van de mariue had", herinnert Groot's journal ${ }^{1}$.

De strijd werd niet alleen te land, doch ook te water gevoerd, daar de rebellen de stoutmoedigheid hadden zich ook in vaartuigen te wagen. "Van tijd tot tijd vertoonden zich ook vijandelijke vaartuigen aan den mond van de baai", verhaalt Boelen ${ }^{2}$, "op welke dan jacht werd gemakt met de barkas of de gewapende orembaai. Zoo had ik op den $4^{\mathrm{n}}$ October een gelukkige ontmoeting op den hoek Oma bij de negorij Siri Sori." Over den $4^{\text {n }}$ lezen wij in Groot's journaal: "Zonden de barkas om water te halen, dog de put ledig zijude, kwam dezelve zonder water aan boord.... Zagen een praauw om de Zuidhoek komen. Zonden dadelijk drie vaartuigen gewapend om de prau te agtervolgen, waarop hij weder zich retiereerde; ook waren an de Zuid Oostzijde verscheidene visschers in kleine praauwen, welke ik liet verjagen met eenige geweerschoten uit de chaloupen; ten half 10 waren de vaartuigen weder aan boord."

Toen den $9^{\mathrm{n}}$ October brik Anna van Ambon te Saparoea terug kwam, bracht zij het voor Groot belangrijk bericht, dat Buijskes met belangrijke versterking was aangekomen, waarmede de commandant van de Reygersbergen een gunstig keerpunt in den strijd tegen de rebellen voorzag. "Vlagde", teekent het jourual van dieu $9^{n}$ aan, "met de Engelsche vlag van de Kruis, de Hollandsche vlag van de Groote en de Pruissische vlag van de Voortop om hierdoor den vijand een weinig mismoedig te maken." Welke looze middelen om de rebellen gedweeër te stemmen!

1 Over Nuijs, zie bl. 714 en over Zoutman bl. 692.

2 Boelen-M., bl. 276.

3 Verg. bl. 725 .

EINDE VAN HET TWEEDE GEDEELTE. 
INHOUDSOPGAVE VAN DE INLEIDING EN VAN DE EERSTE TWEE GEDEELTEN.

Blz.

Inleiding

De drie deelen van dit werk . . . . . . . . 339

Aanleiding tot het schrijven er van. . . . . . 339

De daarbij gebruikte kaarten . . . . . . . . . 340

Van de geraadpleegde scheepsjournalen. . . . . . . 341

Van de geraadpleegde Engelhard-verzameling. . . . . 342

De officieele bundels der Commissarissen-Generaal . . . 346

De gepubliceerde bronnen. . . . . . . . . . 346

Aanwijzingen over de bijgevoegde schetskaart . . . 353

EERSTE GEDEELTE.

De overneming van de Molnkken uit hauden der Engelschen in 1817 . . . . . . . . . . . . 355

Hoornstur I. De commissie Engelhard-Van Middelkoop en de ambtenaren ter overneming van de Molukken: December 1816-Januari 1817. . . . . . . . . . . . 357

Brieven van den Landvoogd in October 1816 over de naderende wegzending der expeditie voor de Molukken bl. 35̃. - Besluiten in December 1816, betrekkelijk behoeften, schepen en ambtenaren voor de Molukken bl. 358. - De instructiën en verhoudingen van de commissie EngelhardVan Middelkoop, zoomede van den gouverneur der Molukken, vastgesteld bij besluit van 31 Januari $1817 \mathrm{bl}$. 359. - Secretaris Von Baumhauer bl. 361. - Resident Berkhoff van Banda bl. 364. - Resident Van deu Berg van Saparoea bl. 364. - Zijn vader. bl. 365. - De be- 
voorrechting van Van den Berg jr. bl. 367. - Resident Neijs van Ternate. bl. 368. - De hoofdadministrateurs Croese en Moorrees bl. 369. - Resident Martheze van Menado bl. 370. - Resident Burghgraaff van Hila en Larike bl. 370. - Resident Uijtenbroek van Haroekoe bl. 371. - Regeling der bezoldigingen met verbod van stille winsten: Jauuari 1817 bl. 373. — Uiteenzetting aan Koloniën van het door C. C. G. G. verrichte: Januari 1817 bl. 374. - Namen van de voor de Molukken bestemde schepen bl. 375. - Eerste toepassing op Europeanen van het recht van uitzetting: April 1817 bl. 376 .

Hoofdstuk II. De beginselen, waardoor de Commissie-Generaal zich ten aanzien van het gouvernement der Molukken deed leiden. 378

Commissaris Éngelhard en de opperresident Bryant Martin bl. 378. - Engelhard's Pointen van elucidatie bl. 379. De organisatiën der specerijperken op Banda in 1794-1810 bl. 379. - De organisatiën in de Molukken onder het Engelsch tusschenbestuur, blijkens Martin's memorie van 14. April 1817 bl. 383. - Inkomsten bl. 383. - Rechterlijke macht bl. 384. - Handel bl. 384. - Beheer bl. 384. Staatkunde bl. 385. - Engelhard's beschouwing over Teruate bl. 38i. - En over Menado bl. 387. - Zoomede over Timor bl. 388. - De hoegrootheid der verplichte levering onder het Engelsch bestuur bl. 389. - De door Daendels als overloopers gequalificeerde ambtenaren bl. 389. Engelhard over den staat, waarin zich het Engelsch bestuur bevindt bl. 391. - Daendels' voornemen om de bezitting van Ternate in te trekken bl. 391. - Engelhard's verdediging van het specerij-monopolie der O. I. C. bl. 393. Zijn waardeering van de Specerij-eilanden bl. 395. Zijn meening over gemis aan voordeel bij invoering van een belasting in geld bl. 397. - Vreest niet specerij-cultuur in vreemde koloniën bl. 399. - Het gewicht van de praktijk der uitroeiing van de specerij-boomen wordt door hem verkleind bl. 400 .

Hoofdstuk III. Uitrusting der expeditie voor de overneming der Molukken

Samenstelling der expeditie te Soerabaja bl. 403. - 
Uitrusting van de Reygersbergen te Batavia bl. 403. De overste Kraijenhoff en de majoor Beetjes bl. 403. Ingehuurde transportschepen bl. 406. - 's Landvoogds brief d.d. 7 Februari 1817 aan Koloniëu over het vertrek van de Reygersbergen met troepen bl. 406. - Reis van de Reygersbergen met de Swallow vau Batavia naar Sidajoe d.d. 5-13 Februari bl. 408. - Rapport van C. C. G. G. d.d. 8 Februari 1817 naar Holland hierover bl. 409. - De Evertsen van Makasser te Soerabaja. bl. 410. - De commandant Dietz en zijn eerste officier Ver Huell bl. 410. De Nassau en commandant Sloterdijk bl. 411.

Hoofdstuk IV. De aankomst van de Nederlandsche commissie te Ambon d.d. 8 Maart 1817. . . . . . . . . . . 412

Het natuurschoon van Ambon bl. 412. - Hitoe en Leitimor bl. 413. - Ondergang van Hitoe's vrijheid bl. 4.14. - De weg Roema tiga-Hitoe lama bl. 415. De binnenbaai van Ambon bl. 416. - De pas van Bagoeala bl. 417. - De baai van Wai bl. 419. - De ligging van de hoofdplaats Ambon bl. 420. - Batoe gadjah bl. 423. Batoe mera bl. 425. - Aankomst der Commissie bl. 425.

Hoordstuk V. De conventiën van 24 Maart en 10 Mei 1817 betrekkelijk de overneming der Molukken . . . . . 426

Ontvangst der Nederlandsche commissie te Amboina: 8 Mart bl. 426. - De eisch, dat inkomsten en lasten zouden aanvangen te loopen met de aankomst der onzen bl. 428. - Het sluiten der conventiën en vertrek van den Britschen opperresident Martin d.d. 17 Mei bl. 430. Dezerzijdsche waardeering van Martin bl. 430. - De inhoud der conventiën bl. 433. - Overdracht van de notemuskat bl. 433. - Eu van de foelie bl. 435. Zoomede van de kruidnagelen bl. 436. - Tijdstip, warop de inkomsten voor ons zouden ingaan bl. 436. - De slavenquaestie bl. 436 - Schulden aan de Diakonie- en Leprozenkassen te Ambon bl. 440. - Uitvoer der Britsche goederen, datum der overgave van Ambon, overgave van de archieven bl. 442. - Begrip der bepaling, dat de overgave moest plaats vinden in den stat, waarin de forten, enz. zich bevonden op 13 Augustus 1814 bl. $442-$ 
Verzekering, dat geen Britsche aanspraken op niet bezette eilanden zouden gedaan worden bl. 445. - Overneming van een paar stukken land te Ambon bl. 445. - De gemoeti-onderneming te Kema bl. 446. - De gouvernementslijnwaad winkel bl. 447 .

Hoofdstuk VI. Aanvaarding van het Nederlandsche bestuur te Ambon en de algemeene indruk er over . . . . . . . 450

Overneming te Ambon d.d. 25 Maart 1817 bl. 450.Hoe de Moluksche commissie de inrichtingen der Engelschen aantrof bl. 450. - De Superintendent over de negorijen te Ambon bl. 450. - En die over de scholen bl. 45l Gemis aan sympathie voor onze terugkomst bij de Inlanders bl. 452. - Ontbinding van het Britsch-Ambonsche militaire korps bl. 453. - Mislukking onzer werving bl. 454. Engelhard's indrukken van Ambon bl. 457 .

Hoofdstuk VII. Beschrijving der toenmalige residentiën op Hitoe en de Oeliasers, benevens van Ceram . . . . . 461

Het gewest Hila en Larike, w. o. Manipa en een deel van Ceram bl. 461. - De vroegere versterkingen der negorijen op Hitoe en de Oeliasers bl. 464. - Het gewest Haroekoe bl. 465. - Het gewest Saparoea bl. 468. - Het eiland Noesa Laoet bl. 475. - Ceram bl. 476 .

Hoofdstuk VIII. De bevolking van Ambon en de Oeliasers, benevens van Ceram . . . . . . . . . . . . . 477

Haar lastige aard bl. 477. - Haar godsdienst bl. 477 De schoolmeesters bl. 479. — Predikanten bl. 481. Burgers en Negorij-bevolking bl. 484. - De regenten bl. 485. - De soa-hoofden bl. 486. - Dati's bl. 486. De bevolking van Ceram bl. 486 .

Hoofdstuk IX. De overneming van Banda, Ternate en Menado. 488

Vertraging in het vertrek vau Evertsen en Reygersbergen van Ambon bl. 488. - Overlijden van den commandant van den Evertsen d.d. 24 Maart bl. 489. - Banda bl. 491.Aankomst van den Evertsen ter reede van Neira d.d. 29 Maart bl. 492. - Overgave van Banda door resident Sergeant aan onzen resident Berkhoff d.d. 2 April bl. 493. Terugkeer van den Britschen resident met den Mandarijn 
d.d. 6 April en van den Evertsen d.d. 30 d.a. v. bl. 493.-

Vertrek van de Reygersbergen naar Ternate d.d. 9 April bl. 493. - Aankomst te Ternate d.d. 24 April en overneming den $30^{\mathrm{n}}$ d.a. v. van den Britschen resident Mackenzie bl. 494. - De naijver tusschen de vorsten van Ternate en Tidore bl. 497. - Secretaris Otto en commandant Muilman bl. 499. - Geschillen in het Rijk van Tidore bl. 500. Vertrek van den voor Menado bestemden resident Martheze met de Nautilus d.d. 12 April en overneming van Menado d.d. 21 d. a. v. bl. 503. - Reis van de Reygersbergen van Ternate naar Kema d.d. 8-15 Mei bl. 504. - Kema en Menado bl. 504. - Mackenzie van Ternate met de Antelope en de Reygersbergen te Ambon terug bl. 505 .

HoofDsTuk X. Het eerste rapport der Moluksche commissie aan Commissarissen-Generaal d.d. 28 April 1817 . . . . . 507

HoofDstuk XI. De oneenigheden tusschen de commissarissen Engelhard en Van Middelkoop. . . . . . . . . . 523

De wanverhouding sinds 25 Maart bl. 523. - Engelhard's mededeelingen er over bl. 523. - De eerste uitbarsting met het vertrek van Martheze naar Menado in April bl. 524. - De uitbarsting van 3-4 Juni bl. 528. - En van 8 Juni bl. 529. - Rapport er over d.d. 12 Juni van Engelhard aan C. C. G. G. bl. 531. - En Engelhard's brief d.d. 12 Juni er over aan zwager Van Basel bl. 533. - Ongedagteekende stukken van Engelhard bl. 554. Buijskes' beoordeeling van de houding der Commissarissen bl. 554. - Engelhard voorbijgegaan als raad van Indië bl. 555. - Zijn pensionneering bl. 556 . 


\section{TWEEDE GEDEELTE.}

\section{De opstand in de Molukken onder het bestuur}

der commissie Engelhard-Van Middelkoop . . . . 559

Hoordstuk I. Over de oorzaken van den opstand . . . . . . 561

Het milder Engelsche tusschenbestuur bl. 561. - De druk onzer O. I. C. bl. 362. - De gunstiger meening der Inlanders over het Britsche bestuur bl. 563. - De waarschuwingen over verzet tegen het Nederlandsche bestuur bl. 564. - Het geldgebrek der Moluksche commissie bl. 568. - Engelhard's meening over de oorzaken van den opstand bl. 570. - Buijskes' rapport betrekkelijk die oorzaken bl. 570. - Het rapport.Porto bl. 578 .

Hoordstuk II. De opstand te Saparoea: 14-16 Mei 1817 . 580

Het begin des opstands : 14 Mei bl. 580. — Resident Van den Berg d.d. 15 Mei te Porto gevangen genomen bl. 582. - Hoofden der rebelleu bl. 582. - De Resident naar Đuurstede teruggebracht: 15 Mei bl. 584. - Bericht van mevrouw Van den Berg naar Ambon: 15 Mei bl. 588. Vermeestering van Duurstede door de rebellen: $16 \mathrm{Mei}$ bl. 588. - Redding van 's Residents oudsten zoon bl. 590. Het rapport-Porto over den $16^{\mathrm{n}}$ Mei bl. 592.

Hoof Dsтuk III. De overwegingen tot onderdrukking van den opstand: $16 \mathrm{Mei}$. . . . . . . . . . . . . . .

Uitstel der verzending van specerij-ladingen naar Batavia bl. 594. - Bericht van den opstand te Ambon bl. 594. Houding van Ver Huell bl. 595. - Het bevel tot het aanhouden van den Evertsen bl. 596. - De Iris bl. 596. Engelhard's mededeeling over het aanhouden van den Evertsen bl. 598.

Hoofdstuk IV. Organisatie van de expeditie tegen Saparoea: 16-17 Mei. . . . . . . . . . . . . . . . 599 
Gedwongen levering van orembaais bl. 599. - Houding van overste Kraijenhoff bl. 601. - Beetjes als expeditiecommandant bl. 602. - Samenstelling der expeditie bl. 604 . - Haroekoe het uitgangspunt der expeditionnaire-vloot bl. 605. - Het reizen met orembaais bl. 606 .

Hoopdstuk V. De expeditie van 17-20 Mei 1817 naar Saparoea 608

Organisatie der expeditie op de hoofdplaats Ambon, vertrek van Martin, een prins van Gilolo geïnterneerd op een oorlogsschip, Walraven naar Hila: 17 Mei bl. 608.Tocht te voet der troepen tot Soeli en Musquetier vooruit naar Haroekoe: 17 Mei bl. 609. - Marsch naar Tial en overvaart naar Haroekoe: 18-19 Mei bl. 609. - De expeditie over Pelaoe naar Saparoea: 19-20 Mei bl. 611. Landing der expeditie: 20 Mei bl. 611.- Engelhard's beschrijving van het vertrek der expeditie en de vaart naar Sapazoea bl. 612. - De poging der expeditie tot vermeestering van Duurstede bl. 613. - De terugtocht: 20 Mei bl. 617. - Van de prauwen, waarin de onzen zich trachtten te redden: 20-21 Mei bl. 619.- Van de in leven geblevenen bl. 621. - Het rapport-Porto over den $20^{\text {n }}$ Mei bl. 623. - Engelhard's bericht over de nederlaag bl. 624. - Thomas Matulesi versterkt het eiland Saparoea bl. 624. - Eed van geheimhouding door de rebellen bl. 625. - De indruk te Ambon en Engelhard's uiting over de nederlang bl. 626 .

Hoofdstuk VI. Localiseering van den geest van verzet op Ambon $629^{\circ}$

Versterking van de militaire macht te Ambon bl. 629. Weigering door ons bestuur van hulp te verleenen, door Ternate, Tidore en Ceram bl. 630. - Het overbrengen van staatsgevangenen aan boord der oorlogsschepen bl. 631. - Verzet op Hitoe: Juni-Juli bl. 632. - Staat der rebellie aldaar en op Zuid-Ceram in den aanvang van Augustus bl. 636. - Resident De Haart bl. 637 .

Hoofdstuk VII. De onlusten op Haroekve: 21 Mei tot medio Juni . . . . . . . . . . . . . . . . . . 639

Adelborst Scheidius naar Haroekoe: 22-23 Mei bl. 639. - Fort Zeelandia onder adelborst Musquetier bl. 
640. - De Britsche koopvaarder de Zwaluw en het Britsche Compagniesschip Nautilus bl. 640.- Vertrek van de gewapende Zwaluw d.d. 22 Mei naar Haroekoe bl. 642.Vertrek van de Iris derwaarts : 25 Mei bl. 643. - Komst te Haroekoe van kapitein Van Driel en adelborst Scheidius; vertrek van Musquetier bl. 643. - De radja van Haroekoe bl. 643. - Halalioe, Pelaoe, Kabaoe in opstand bl. 644. De anval der rebellen d.d. 30 Mei bl. 644. - En op 3 Juni bl. 645. - Engelhard's mededeelingen over deze aanvallen bl. 647. - Aanvallen op 9 en 14 Juni bl. 650. - Bestraffing van Oma bl. 65l. - Zoomede van Kabaoe en Rohomoni: 15 Juni bl. 651. - Het rapportPorto over Matulesi's teleurstelling bl. 652. - Engelhard's denkbeeld om de bevolking der Oeliasers uit te roeien bl. 654. - Engelhard's niet volbrachte plannen om naar het tooneel van den opstand te gaan bl. 657 .

HoofdsTuK VIII. Tuchtiging van landschap Hatawano, noordoostelijk gedeelte van Saparoea: 9-12 Juli . . . . . . .659

Bestemming van de Reygersbergen met Iris en Dispatch naar Hatawano bl. 659. - Reis van de Reygersbergen: 4-9 Juli bl. 660. - Beschieting door de Reygersbergen van Hatawano: 9 Juli bl. 662. - Nadering van de Iris 10 Juli bl. 663. - Hatawano onder kruisvuur genomen door Reygersbergen en Iris: 12 Juli bl. 664. - Ontevredenheid van commandant Groot op het bestuur te Ambon bl. 665 .

Hoofdstuk IX. Vergeefsche onderhandelingen met het landschap Hatawano: 12-21 Juli . . . . . . . . . . . . 667

Groot's aaubieding van vrede: 12-13 Juli bl. 667.De besprekingen met de rebellen d.d. 14 Juli op het strand met Ellinghuijzen en Christiaausen bl. 669. - Zending van Christiaansen naar hoofdplaats Saparoea: 14 Juli bl. 671. - En van Boelen naar Ambon: 14 Juli bl. 672.Correspondentie der rebellen met Groot: 15 Juli bl. 673. Zending van Feldmann naar hoofdplaats Saparoea: 17 Juli bl. 673. - Boelen's reis in orembaai naar Haroekoe: 14-15 Juli bl. 673. - Per prauw van Haroekoe naar Toelehoe: 15 Juli bl. 675. - Per draagstoel naar Soeli, 
per prauw naar Bagoeala, te voet over den Pas, per prauw naar hoofdplaats Ambon: 16 Juli bl. 675. - Verblijf te Ambon: 16-17 Juli bl. 676. - Terugreis naar Soeli en Toelehoe: 17 Juli bl. 677. - Terugreis naar Haroekoe: 18 Juli bl. 678. —Terugreis per orembaai naar de Reygersbergen: 18-19 Juli bl. 679. - De door Boelen overgebrachte brieven van Ambou bl. 681. - Komst van de Dispatch: 18 Juli bl. 681. — Tocht van Feldmann naar hoofdplaats Saparoea en Haria : 17 Juli bl. 681. - Verblijf te Saparoea van 17 op 18 en van 18 op $19 \mathrm{Juli}$ bl. 682. - Vergadering van Groot c.s. met de rebelleu op de kust van Hatawano: 19 Juli bl. 686. - Het ondergane lijden van Christiaansen bl. 688. - Voortzetting der correspondentie tot $20 \mathrm{Juli}$ bl. 688 .

Hoofdstuk X. Tweede tuichtiging van Hatawano: 21-31 Juli. 689

Landing aan de kust van Hatawano: 21 Juli bl. 689. Hatawano nader verwoest 22-26 Juli bl. 690. - Vertrek van de Dispatch naar Haroekoe, 21 Juli. bl. 692. Opneming van gevluchte Ambonsche matrozen: $20 \mathrm{Juli}$ bl. 692. - Een spion van Nolot gevangen gezet en ontsuapt 22.30 Juli bl. 692. - De Iris naar Noesa Laoet en terugkeer met den patih van Akoon: 26 Juli bl. 694. - De Iris naar Ambon bl. 698. - Eeu tweede opneming van gevluchten als matrozen: 30 Juli bl. 699. - Terugkeer van de Dispatch van Hatawono: 31 Juli bl. 700.

Hoofdstuk XI. Fort Duurstede hernomen: commandant Ellinghuïzen: 3 Angustus-3 September.

Voorbereiding tot den aanval op fort Duurstede: 1-2 Augustus bl. 701. - Inueming van Duurstede: 3 Augustus bl. 702. - De dagen van 4-8 Augustus bl. 704. - Met de bezetting van Duurstede is Saparoea niet onderworpen bl. 706. - De Anna Maria brengt onvoldoende versterking, maar een militaire commissie voor opneming van het fort: 6-10 Augustus bl. 707. - De Dispatch brengt evenzeer onvoldoende versterking: 7-15 Augustus bl. 708. - De Anna Maria opnieuw met onvoldoende versterking van Ambou te Saparoea: 22 Augustus bl. 710. - Heen- en wederzending van den patih van Akoon bl. 710. - Eenige 
uittreksels uit Groot's journaal over het gevaarlijke van den toestand: 24-31 Augustus bl. 711. - Komst van versterking met de Dispatch: 3 September bl. 713. Ellinghuijzen vervangen door Lisuet : 3 September bl. 714.-

Hoofdstuk XII. Frort Duurstede onder commando van Lisnet: 3 September-9 October . . . . . . . . . . . .715

Schermutseling op 3 September bl. 715. - Uitval op den $4^{\mathrm{n}}$ bl. 715. - Het vermanen tot onderwerping bl. 717.Gesprekken tusschen de rebellen eu onze bezetting: 5 September bl. 718. - Aanval van de rebellen in den nacht van 5-6 September bl. 719. - Ontdekking van geld en van het lijk, vermoedelijk van mevr. Van den Berg: 6 September bl. 720. - Komst van de Anna Maria met versterking: 10 September bl. 721. - Terug naar Ambon de patih van Akoon en luitenant Christiaansen: 12 September bl. 722. - Javanen en Amboneezen der bezetting Duurstede schieten op elkander: 17 September bl.723.Kleine uitvalleu op 18-21 September bl. 723. - Mislukte uitval op den 22n bl. 724. - De Anna Maria opnieuw te Saparoea : 28 September bl. 725. - Vernieling der visschersvaartuigen bl. 726. - Bericht te Saparoea der ankomst vau Buijskes te Ambon: 9 October bl. 726 . 